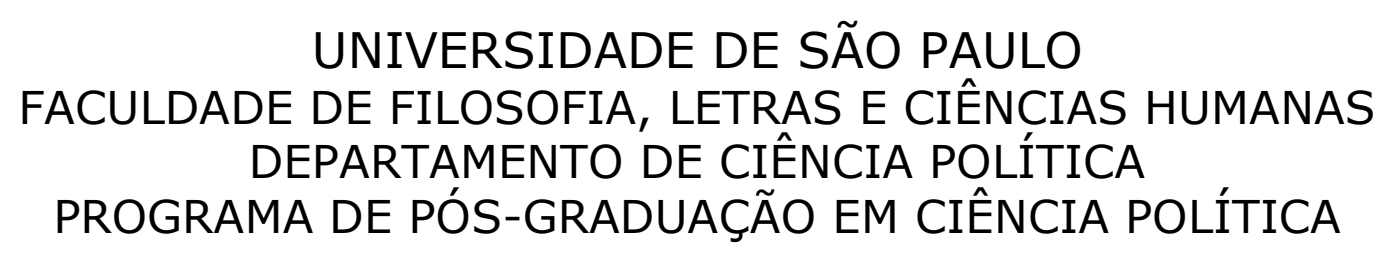

Sérgio Praça

A evolução de instituições orçamentárias no Brasil, 1987-2008 


\section{Sérgio Praça}

\section{A evolução de instituições orçamentárias no Brasil, 1987-2008}

Tese apresentada ao programa de Pós-Graduação em Ciência Política do Departamento de Ciência Política da Faculdade de Filosofia, Letras e Ciências Humanas da Universidade de São Paulo, para obtenção do título de Doutor em Ciência Política sob a orientação do Prof. Dr. Matthew M. Taylor 
À memória de:

Maria D'Alva Kinzo Mário de Jesus Praça Pedro Chamlian Ferreira dos Santos 


\section{Agradecimentos}

Sinto-me sortudo por ter tantas pessoas e instituições a agradecer ao terminar de escrever este trabalho.

Antes de ninguém, sou muito grato a meu orientador, Matthew M. Taylor, pela dedicação, paciência e profissionalismo com o qual me ajudou desde o fim de 2006. Sua empolgação com minhas idéias e o respeito a meu trabalho foram absolutamente fundamentais. Suas sugestões e críticas, sempre extremamente respeitosas, norteiam todos os capítulos.

Caso eu não tivesse conhecido Clóvis de Barros Filho em 2000 e começado a trabalhar com ele pouco depois, ainda estudando jornalismo, minha vida seria bastante diferente. A ele agradeço todas as oportunidades que tive no começo da carreira acadêmica.

Devo a Humberto Dantas a escolha pela Ciência Política. Antes de qualquer outra pessoa exceto Clóvis, ele acreditou no meu potencial acadêmico e me apresentou para Maria D’Alva Kinzo, minha primeira orientadora na USP, de quem sinto falta.

A Simone Diniz sou extremamente grato não só pela leitura de todos os capítulos e por muitas conversas em torno das idéias desta tese, mas também pela amizade e apoio nos momentos mais difíceis. Lincoln Noronha leu todos os capítulos e ofereceu comentários valiosos, sobretudo em relação à Assembléia Nacional Constituinte - a ele também agradeço.

Tive a sorte e honra de receber comentários a diversos capítulos em vários momentos da elaboração da tese, assim como a oportunidade de apresentá-los em encontros profissionais. Argelina Figueiredo no encontro da ABCP em 2008, Fabiano Santos em outro encontro da ABCP em 2009 e Jason A. MacDonald no encontro da Apsa em 2009 ofereceram críticas e sugestões valiosas a alguns dos capítulos.

Dentro do Departamento de Ciência Política da USP, contei com comentários de Fernando Limongi e Rafael Villa no Seminário de Tese, no início de 2007. Um ano depois, Limongi e Bruno Speck ofereceram excelentes críticas no exame de qualificação. Agradeço especialmente o entusiasmo de Fernando Limongi nestas e outras oportunidades com minhas idéias para a tese.

Aos funcionários do Departamento também tenho muito a agradecer, especialmente Rai e Vivian, sempre disponíveis para resolver todas as minhas dúvidas.

Viajei para Brasília em Maio/2008 e Janeiro/2009 para realizar entrevistas e colher material. Agradeço Leany Lemos por me colocar em contato com diversos consultores de orçamento do Senado Federal. Carlos Marshall, Eugênio Gregiannin, Fernando Ramalho 
Bittencourt, Helio Tollini, Rita de Cássia, Robison Castro, e outros consultores de orçamento da Câmara dos Deputados e Senado Federal conversaram longamente comigo, alguns deles mais de uma vez. Muitas das idéias desta tese se originaram em conversas extremamente esclarecedoras com eles. Carlos Marshall disponibilizou material referente à tramitação da Resolução 1/2006 e Helio Tollini em relação à Resolução 2/1995 que foram absolutamente fundamentais para os capítulos quatro e cinco. Funcionários da Comissão Mista de Orçamento me deram acesso às atas da comissão criada em 2005 para discutir a reforma orçamentária no Congresso Nacional. Funcionários do Arquivo do Senado Federal foram extremamente solícitos e profissionais ao me ajudarem a encontrar documentos relativos ao processo orçamentário de 1988 a 2000. Não é exagero afirmar que, sem este material, meu objeto de pesquisa teria que ser outro. Agradeço profundamente a todos que me ajudaram em Brasília, sobretudo meu amigo Michel Laham, por me receber durante duas semanas em Maio/2008.

Devo a Eber Santa Helena, Fernando Ramalho, Helio Tollini, Julio Faundez e Marta Arretche diversas indicações bibliográficas úteis. Agradeço Andréa Freitas por dados referentes à disciplina partidária dos parlamentares brasileiros utilizados no capítulo cinco e Andreza Davidian por ajudar na pesquisa sobre a Assembléia Nacional Constituinte.

Agradeço CNPq e Capes pelo apoio financeiro e Edward Gibson e Brodie Fischer por me acolherem durante breve período na Northwestern University no primeiro semestre de 2008. Sou também extremamente grato a Valmir Marchiori e Fabiana pelo apoio naquela e em outras épocas. Eles sabem como foram importantes.

A meus amigos Antônio Ferreira Filho, Arthur Meucci, Beatriz Rey, Fernão Ketelhuth, Liana Mesquita de Almeida, Kenia Archas e Patricia Trajano devo os diversos momentos divertidos e apoio durante os episódios de mau humor que acompanharam o andamento desta tese desde 2006.

Finalmente, agradeço de novo meus pais, Mário e Walderez, pelo amor e paciência de sempre. 


\section{RESUMO}

PRAÇA, S. A evolução de instituições orçamentárias no Brasil, 1987-2008. 2010. 264 f. Tese (Doutorado) - Faculdade de Filosofia, Letras e Ciências Humanas. Departamento de Ciência Política, Universidade de São Paulo, São Paulo, 2010.

O principal argumento deste trabalho é que a interação entre interesses, idéias e enquadramentos discursivos (frames) permite explicar como e por que certas instituições orçamentárias brasileiras foram escolhidas, desde 1987, em vez de outras. Defendo que os interesses dos parlamentares a respeito das instituições orçamentárias é definido, em grande parte, por como essas instituições funcionam na prática. Mostro que a estratégia de execução orçamentária utilizada pelo Executivo Brasileiro no período pós1988 é fundamental para explicar por que parlamentares da coalizão devem, em tese, defender limites ao emendamento, a organização centralizada da Comissão Mista de Orçamento e o Orçamento Autorizativo. Os parlamentares da oposição, por sua vez, devem defender emendamento ilimitado, a descentralização da comissão orçamentária e o Orçamento Impositivo.

Três critical junctures foram fundamentais para definir as instituições orçamentárias brasileiras no recente período democrático: a Assembléia Constituinte de 1987-1988, o período pós-CPI de 1994-1995 e a época de 2005-2006. Ao inserir as escolhas de instituições orçamentárias na lógica do processo constituinte, entende-se por que certas instituições da ditadura militar foram mantidas (por exemplo, a Comissão Mista de Orçamento) e outras foram ressuscitadas, parcialmente, do regime democrático de 1946-1964 (por exemplo, a prerrogativa de parlamentares emendarem o orçamento). Em seguida, o trabalho aborda as escolhas pós-constituintes, avaliando como escândalos de corrupção e as critical junctures derivadas parcialmente deles ajudaram a alterar diversos aspectos do emendamento orçamentário no Brasil. Mostro também como o entrepreneur de oposição Ricardo Barros conseguiu, em 2006, ser extremamente bem-sucedido na descentralização de aspectos da Comissão Mista de Orçamento.

A estabilidade do Orçamento Autorizativo no Brasil é analisado em seguida e pode ser visto como um caso complementar aos demais, pois trata de uma quase mudança institucional. Os enquadramentos discursivos utilizados pelo entrepreneur Antônio Carlos Magalhães, principal defensor do fim do Orçamento Autorizativo, revelam quais interesses legislativos estiveram presentes na decisão de manter essa instituição.

Palavras-chave: Orçamento federal, desenvolvimento institucional, relações Executivo-Legislativo, formação de preferências, enquadramentos discursivos 


\section{ABSTRACT}

PRAÇA, S. The evolution of budgeting institutions in Brazil, 19872008. 2010. 264 f. Thesis (Doctoral) - Faculdade de Filosofia, Letras e Ciências Humanas. Departamento de Ciência Política, Universidade de São Paulo, São Paulo, 2010.

How does the interaction between interests, ideas and frames help explain institutional development? This dissertation takes the evolution of budgeting institutions in Brazil since 1987 as a case study to answer this question. I argue that congressmen's interests regarding budgeting institutions is mainly defined by how these institutions actually work. I show that the presidential strategy of executing amendments explains why coalition congressmen normally defend limited amendment power, a centralized budget process and the Authoritative Budget. The inverse goes for opposition congressment.

Three critical junctures were very important in the definition of budgeting institutions in the recent democratic period: the National Constituent Assembly in 1987-1988, and two short periods during the unveiling of budgeting corruption scandals in 1994-1995 and 2005-2006. I show how the centralized budget process was kept in the 1988 Constitution and was used by the coalition up to 2006, when an opposition entrepreneur was successful in decentralizing part of the process. Congressmen's prerogatives for amending the budget were enlarged in the 1988 Constitution, but somewhat toned down due to the influence of corruption scandals in shaping the institutional development agenda. Finally, I tackle the problem of how institutions remain stable in processes of reproduction that are not path dependent. I do so by analyzing Brazil's main budgeting institution - the Authoritative Budget - as a case study to consider how control of the legislative agenda by the Executive can be considered a power mechanism through which institutions are endogenously maintained. It also illuminates the limitations of entrepreneurs who almost single-handedly attempt to change institutional arrangements. In this case, the entrepreneur, Antonio Carlos Magalhães, obtained relative success but ultimately failed.

Key Words: federal budget, institutional development, interbranch relations, preference formation, frames 


\section{SUMÁRIO}

Capítulo 1 (p. 11-38)

Dinâmicas institucionais e o papel de interesses, idéias e frames

Capítulo 2 (p. 39-66)

Escolhas institucionais em critical junctures

Capítulo 3 (p. 67-93)

A definição de instituições orçamentárias pelos constituintes de 1987-1988

Capítulo 4 (p. 94-122)

Layering institucional: prerrogativas de emendamento orçamentário

Capítulo 5 (p. 123-159)

Conversão institucional: o caso da Comissão Mista de Orçamento

Capítulo 6 (p. 160-192)

A dinâmica da inércia: a estabilidade do Orçamento Autorizativo no Brasil

Capítulo 7 (p. 193-202)

Considerações Finais

Anexos (p. 203-248)

Bibliografia (p. 249-264) 


\section{LISTA DE TABELAS}

Tabela 1.1: Características institucionais e processos de mudança (p. 15)

Tabela 1.2: Interesses parlamentares e desenho de instituições orçamentárias no Brasil (p. 20)

Tabela 1.3: Atores, idéias, frames e interesses revelados (p. 30)

Tabela 1.4: Frames e características de políticas públicas (p. 31)

Tabela 1.5: Estratégias possíveis do Executivo e apoio às instituições orçamentárias (p. 38 )

Tabela 2.1: Assimetrias de poder e controle das agendas políticas em critical junctures (p. 51)

Tabela 2.2: Criticalness dos períodos analisados (p. 54)

Tabela 2.3: Escolhas institucionais para a Coalizão nas critical junctures de 1995 e 2006 (p. 58)

Tabela 2.4: Escolhas institucionais para a Oposição nas critical junctures de 1995 e 2006 (p. 58)

Tabela 2.5: Escolhas institucionais sobre emendamento orçamentário, 1991-2006 (p. 59)

Tabela 2.6: Escolhas institucionais sobre organização orçamentária, 1991-2006 (p. 60)

Tabela 3.1: Saliência dos assuntos políticos na Veja, 1986-1988 (p. 75)

Tabela 3.2: Comando das subcomissões da ANC e saliência dos assuntos, 1986-1988 (p. 78 )

Tabela 3.3: Posição ideológica dos relatores das subcomissões da Assembléia Nacional Constituinte (p. 80)

Tabela 3.4: Posição ideológica da Subcomissão de Orçamento da ANC, 1987 (p. 82)

Tabela 3.5: Escolhas da Subcomissão de Orçamento e Fiscalização Financeira sobre processo orçamentário (p. 87)

Tabela 3.6: Escolhas da Assembléia Nacional Constituinte sobre processo orçamentário (p. 90-91)

Tabela 4.1: Emendas Individuais e Coletivas - Quantidade Apresentada e Valor Aprovado, 1994-2007 (p. 107) 
Tabela 4.2: Corrupção, entrepreneurs e escolhas sobre emendamento, 1988-2008 (p. 119)

Tabela 5.1: Governismo da Comissão Mista de Orçamento, 1988-2007 (p. 128)

Tabela 5.2: Uso de instituições relativas à organização da comissão orçamentária, 19882006 (p. 129)

Tabela 5.3: Escolhas possíveis relativas à organização legislativa do processo orçamentário (p. 144)

Tabela 5.4: Corrupção, entrepreneurs e escolhas sobre a organização da CMO, 19882008 (p.158)

Tabela 6.1: Instituições orçamentárias plausíveis e efeitos para atores políticos (p. 166)

Tabela 6.2: Projetos de Orçamento Impositivo na Câmara dos Deputados e Senado Federal (p. 168)

Tabela 6.3: Payoffs para Magalhães de Orçamento Autorizativo x Orçamento Impositivo (p. 173)

Tabela 6.4: Situação atual das propostas de Orçamento Impositivo no Brasil (p. 178)

Tabela 6.5: Frames Presumidos dos Atores Políticos em relação ao Orçamento Impositivo (p. 189 ) 


\section{Capítulo 1}

\section{Dinâmicas institucionais e o papel de interesses, idéias e frames}

Entender dinâmicas institucionais - ou seja, estabilidade e mudanças em desenhos de instituições - tem sido um desafio recorrente para economistas, sociólogos e cientistas políticos nas últimas três décadas. A interação entres essas três perspectivas analíticas, bem como as nada ignoráveis discordâncias internas a cada uma dessas áreas, já resultou em avanços substanciais na compreensão de por que e como as instituições mudam $^{1}$.

Esta tese pretende contribuir duplamente a esta literatura. A primeira contribuição é de ordem teórica. Apesar da crescente importância do estudo de "idéias, interesses e instituições" na ciência política, ainda sabemos pouco, por exemplo, sobre como a ideologia importa para escolhas institucionais; sobre como idéias, entendidas em sentido restrito, são determinadas ou não por interesses; sobre quais interesses de atores políticos importam em quais momentos; e, finalmente, sobre como a vocalização de idéias por atores políticos permite observar quais interesses estão em jogo, de modo estratégico ou não.

A segunda possível contribuição da tese é substantiva. A evolução de instituições orçamentárias, um dos pontos centrais para a análise de escolhas macroeconômicas em qualquer país, tem sido relativamente negligenciada no Brasil. Embora haja diversos trabalhos que tratam dos efeitos das instituições orçamentárias para a barganha política (Pereira e Mueller 2004, Alston e Mueller 2005), a reeleição de parlamentares (Pereira e Rennó 2003, Mesquita 2009), as relações interministerias (Pinheiro 1996) e as relações Executivo-Legislativo (Figueiredo e Limongi 2005, 2008), não conheço trabalho academico específico sobre a dinâmica de escolhas de regras orçamentárias. Além disso, devido a diversos escândalos de corrupção orçamentária nos últimos vinte anos ${ }^{2}$, este tema tem sido tratado por jornalistas (Krieger et. al 1994),

\footnotetext{
${ }^{1}$ Olsen (2009) e Kingston e Caballero (2009) revisam esta literatura.

2 Os dois principais escândalos foram os dos "anões do orçamento", em 1993-1994 e dos "sanguessugas" em 2005-2006. Os “anões” eram o grupo político que controlava o processo orçamentário no Brasil de 1989 a 1993 a partir da Comissão Mista de Orçamento, interagindo de modo corrupto tanto com integrantes do Executivo quanto com certas empreiteiras. Os "sanguessugas" foram um grupo composto por 72 parlamentares, desmascarados em 2006, que destinavam emendas orçamentárias ligadas à área da saúde e compartilhavam, com prefeitos e burocratas do Ministério da Saúde, os ganhos corruptos obtidos a partir de licitações municipais irregulares ligadas a essas emendas.
} 
antropólogos (Bezerra 1999, Carneiro 2005) e economistas (Gonçalves da Silva 2002) quase exclusivamente sob esta ótica ${ }^{3}$.

O propósito deste capítulo é explicitar os fundamentos teóricos que norteiam a tese. Considero tanto o papel do histórico das instituições e seu funcionamento na prática (como fazem os institucionalistas históricos) quanto o papel de critical junctures como momentos nos quais idéias sobre desenhos institucionais circulam com facilidade e permitem a atores racionais realizarem escolhas de acordo com seus interesses de curto e longo prazo (como fazem alguns institucionalistas de escolha racional).

As três principais questões a serem respondidas pela tese são: a quais interesses e idéias a dinâmica institucional de instituições orçamentárias brasileiras respondeu de 1986 a 2008? Qual foi a importância de critical junctures - a Assembléia Nacional Constituinte (1987-1988), o período da CPI do Orçamento (1994-1995) e o período da CPI das Ambulâncias/Sanguessugas (2005-2006) - para a definição desses interesses e idéias que orientaram escolhas institucionais? Como instituições orçamentárias reproduziram-se neste período e quais foram os fatores que determinaram ajustes pequenos, ajustes relevantes e mudanças institucionais de maior alcance?

A necessidade de integrar a perspectiva de escolha racional com o institucionalismo histórico se torna clara se considerarmos que paradoxalmente, no período analisado, os parlamentares brasileiros 1) limitaram, progressivamente, diversas de suas prerrogativas referentes ao emendamento do orçamento; 2) não aprovaram o Orçamento Impositivo em substituição ao Orçamento Autorizativo, instituição que confere ao Executivo grande liberdade para realizar gastos; 3) mantiveram, parcialmente, a centralização dos trabalhos da Comissão Mista de Orçamento, apesar da recorrente pressão para descentralizar a comissão.

Esse conjunto de decisões não faz sentido, à primeira vista, considerados puramente os "interesses" legislativos conforme definidos pela linha da escolha racional. No entanto, se a análise levar em conta o funcionamento prático das

\footnotetext{
3 A literatura internacional sobre corrupção, embora extensa, tem dado importância às relações orçamento-corrupção apenas tratando da prática de execução orçamentária (Gauthier e Wane 2006), com pouca ênfase aos desenhos institucionais e as idéias e interesses que os balizam, à exceção de Isaksen (2005). Vale citar também a análise de Fabrizio e Mody (2008) sobre reformas orçamentárias em 23 democracias européias de 1991 a 2004. São três os principais achados: i) a reforma de instituições orçamentárias se torna mais improvável justamente quando ela é mais premente, ou seja, quando os resultados fiscais são ruins; ii) choques econômicos domésticos e externos, quando suficientemente fortes, podem funcionar como pontos em torno dos quais os atores se coordenam para realizar reformas institucionais e iii) quando a situação fiscal é ruim, coalizões "esquerdistas" tendem a reformar instituições orçamentárias com maior freqüência do que coalizões conservadoras.
} 
instituições orçamentárias e como este afeta as relações entre Executivo e Legislativo (algo que chamo abaixo de "apoio contingente"), bem como a importância de entrepreneurs como organizadores de idéias durante critical junctures, as escolhas institucionais dos parlamentares brasileiros tornam-se mais compreensíveis.

Assim, para responder os paradoxos citados acima, diversos elementos teóricos que pertencem ao novo institucionalismo serão mobilizados. Em primeiro lugar, as dinâmicas institucionais analisadas serão inseridas no debate mais recente sobre causas e processos de mudanças institucionais. Certamente a contribuição de Mahoney e Thelen (2009), ao consolidar um framework analítico sobre desenvolvimento institucional em andamento desde Thelen (1999) e Mahoney (2000), é o principal texto com o qual o diálogo teórico deve ser travado. Proponho, no entanto, dois acréscimos a esta perspectiva. O primeiro trata de considerar o duplo papel de enquadramentos discursivos (frames), tanto como reveladores de interesses dos atores (conforme será visto nos capítulos sobre escolhas relativas ao emendamento parlamentar e à organização da Comissão Mista de Orçamento) quanto como instrumentos estratégicos de entrepreneurs (como ficará claro no capítulo sobre o senador Antônio Carlos Magalhães e sua proposta para instituir o Orçamento Impositivo).

O segundo acréscimo teórico trata da noção de "apoio contingente" às instituições. A linha de escolha racional está correta ao considerar que certos interesses dos atores são "induzidos pelas estruturas", mas falta levar em conta o papel que o funcionamento prático das instituições tem para a manifestação desses interesses. Assim, a idéia de "apoio contingente" inspira-se no "consentimento contingente" de Levi (1990) aliado à compliance institucional de que Mahoney e Thelen (2009) falam. O objetivo é realizar um corretivo teórico à criticada "teoria de interesses" (Blyth 2003) dos analistas de escolha racional, bem como aos institucionalistas históricos que dividem atores de acordo com como eles são afetados por instituições - winners delas se aproveitam, losers lamentam e buscam mudanças. A idéia de "apoio contingente" busca mostrar que ganhar ou perder é condicional a como as instituições são usadas na prática. O restante do capítulo é dedicado à explicação dessas contribuições teóricas. 
1) o status quo da literatura sobre como sair do status quo: Mahoney e Thelen (2009)

A análise de dinâmicas institucionais é fortemente relacionada ao antiquíssimo debate sobre a importância de estruturas institucionais (structure) e intencionalidade dos atores (agency) para explicar escolhas e comportamentos políticos. Seguindo Hay (2002, p. 94-95), defino structure como o contexto institucional no qual eventos sociais, políticos e econômicos ocorrem e adquirem sentido para os atores. Agency, por sua vez, refere-se à conduta individual, ou seja, a habilidade ou capacidade de um indivíduo em agir de modo consciente para realizar suas intenções. Implica algo de livre-arbítrio, escolha e autonomia. Indica que o agente podia ter feito outra escolha. E também que a escolha feita foi sujeita à consciência deliberada do indivíduo.

Estudos que conferem centralidade à structure são abundantes no institucionalismo histórico, enquanto a agency de atores é mais estudada por institucionalistas de escolha racional. Inserindo-se em esforços recentes para diminuir essas diferenças internas ao institucionalismo (Katznelson e Weingast 2005, por exemplo), o texto de Mahoney e Thelen (2009) busca conciliar esses dois conceitos a fim de melhor compreender como, por que e a partir de quais atores as mudanças institucionais ocorrrem.

Definem instituições como "instrumentos de distribuição de poder"4 e ocupamse de cinco questões. Estudam as propriedades internas às instituições que permitem mudanças; avaliam como essas propriedades internas incentivam ou permitem atores a se comportarem de modo a buscar mudanças; propõem tipologia para conceitualizar esses atores políticos, denominados change-agents; elencam quais estratégias para mudança prosperam em quais ambientes institucionais; e, por fim, avaliam quais propriedades internas às instituições as deixam vulneráveis a certas estratégias dos change-agents (Mahoney e Thelen 2009, p. 4).

Um dos argumentos básicos dos autores é que mudanças institucionais freqüentemente ocorrem quando problemas de interpretação de regras, imposição (enforcement) e obediência (compliance) ocorrem e abrem espaço para que atores implementem regras existentes de novas maneiras. Mahoney e Thelen (2009) expõem

\footnotetext{
${ }^{4}$ Esta definição é comum para institucionalistas históricos e também ecoa alguns analistas de escolha racional como Knight (1992) e Moe (2005), fugindo à importação acrítica de análises ligadas ao neoinstitucionalismo econômico, que costuma ignorar implicações propriamente políticas ao analisar desenvolvimento institucional.
} 
quatro diferentes processos de mudanças institucionais (São a extinção de regras antigas e a introdução de novas (displacement); a introdução de novas regras que convivem com antigas regras (layering); novos efeitos de regras antigas devido a mudanças no ambiente institucional (drift); uso estratégico de regras antigas, resultando em novos efeitos institucionais (conversion).

Há dois fatores em grande parte responsáveis por definir quais caminhos de mudança resultarão das escolhas de atores (Mahoney e Thelen 2009, p. 23). O primeiro é relacionado ao contexto político: ele fornece aos defensores do status quo possibilidades fortes ou fracas para vetar mudanças? O segundo trata do funcionamento institucional interno: a instituição em questão permite que os atores tenham oportunidades para escolher o modo como certas regras serão implementadas e/ou impostas? A tabela 1.1 abaixo sistematiza esses dois fatores em relacão aos processos de mudança institucional esperados por Mahoney e Thelen (2009).

Tabela 1.1: Características institucionais e processos de mudança

\begin{tabular}{|l|l|l|}
\hline & $\begin{array}{l}\text { Alta possibilidade de } \\
\text { escolher como regras são } \\
\text { impostas }\end{array}$ & $\begin{array}{l}\text { Baixa possibilidade de } \\
\text { escolher como regras são } \\
\text { impostas }\end{array}$ \\
\hline Fortes possibilidades de veto & Layering & Drift \\
\hline Fracas possibilidades de veto & Displacement & Conversion \\
\hline
\end{tabular}

Quanto ao primeiro ponto, a literatura sobre veto players é bastante consolidada. Para o caso de mudanças institucionais, trata-se da idéia de que a distribuição das possibilidades de veto é desigual entre os atores de certo sistema político. Além disso, são freqüentemente determinadas constitucionalmente, tornando difícil sua superação. Assim forçam certos atores a procurar outros meios para mudar regras ao mesmo tempo em que permite a outros atores, aqueles com fortes possibilidades de veto, o mais ou menos confortável manejo do status quo institucional que lhes favorece. Nesta divisão de Mahoney e Thelen (2009), a intenção é discriminar contextos políticos que contêm diversos atores com fortes possibilidades de veto (imaginemos, por exemplo, o processo de emendamento constitucional norte-americano, que confere aos estados enorme poder para vetar mudanças indesejadas) de contextos nos quais aos atores se confere fraca possibilidade de vetar (imaginemos, por exemplo, uma comissão legislativa que exige a concordância de apenas $10 \%$ de seus membros para que certa proposta vá para plenário). 
As mesmas perguntas citadas acima - o contexto político fornece aos defensores do status quo possibilidades fortes ou fracas de vetar mudanças? a instituição em questão permite que os atores tenham oportunidades para escolher o modo como certas regras serão implementadas e/ou impostas? - definem os atores que mobilizam mudanças, denominados por Mahoney e Thelen de change-agents. São quatro os tipos de atores: revolucionários, simbiontes (divididos em dois sub-tipos: parasitários ou mutualísticos), subversivos e oportunistas. Os autores analisam se o ator busca preservar as regras institucionais existentes e se o ator obedece a essas regras ${ }^{5}$.

Não há dúvida de que os autores oferecem interessantes tipologias e hipóteses sobre desenvolvimento institucional. No entanto, como não poderia deixar de ser, a proposta teórica de Mahoney e Thelen diz pouco sobre o conteúdo de dinâmicas institucionais. Trata-se de como interesses dos atores e suas idéias e/ou ideologias interagem de modo a dar forma às propostas concretas. Como esses elementos são, de certo modo, específicos a cada caso, cabe agora avaliar, para o caso das dinâmicas institucionais do processo orçamentário brasileio, quais interesses e idéias estão presentes.

\section{2) interesses, idéias e enquadramentos discursivos}

A partir de quais interesses os parlamentares brasileiros plausivelmente agem para formar e reformar instituições orçamentárias? O trabalho de Schickler (2001) é um excelente ponto de partida, pois analisa mudanças institucionais no Congresso norteamericano. Assim como no caso deste trabalho, trata-se de escolhas feitas por parlamentares, o que torna o livro de Schickler um bom guia para o início da discussão

\footnotetext{
${ }^{5}$ Os revolucionários são atores que conscientemente buscam eliminar regras existentes, e o fazem através de mobilização ativa e visível contra elas. Rejeitam o status quo institucional e nem sempre o obedecem (Mahoney e Thelen 2009, p. 29). Os simbiontes parasitários aproveitam-se de instituições que não desenharam. Exploram uma instituição para fins privados e, ao mesmo tempo, dependem da existência e eficácia em termos gerais desta instituição para obter os ganhos privados. Os simbiontes mutualistas, por sua vez, também se aproveitam de instituições que não implementaram, mas não as desobedecem ou tentam destrui-las: utilizam-nas a favor de seus interesses. Atores subversivos parecem, à primeira vista, apoiar as instituições existentes. Mas estão à espreita, procurando o momento mais propício para atingir seus interesses com outros desenhos institucionais. Enquanto esperam, freqüentemente propõem pequenas mudanças que convivem com as regras já existentes de modo não-destrutivo (Mahoney e Thelen 2009, p. 31). Por fim, atores oportunistas sao ambíguas em relação ao status quo institucional. Nem apoiam nem buscam eliminar as regras, pois se o apoio é contrário a seus interesses, a oposição pode ser custosa e afetar outras relações políticas. Portanto, buscam aproveitar quaisquer possibilidades no sistema institucional existente para atingir seus objetivos (Mahoney e Thelen 2009, p. 33).
} 
sobre interesses dos deputados e senadores brasileiros em relação às instituições orçamentárias.

Sobre a formação de interesses de modo geral, adoto a perspectiva citada por Mahoney (2005, p. 325), para quem certos analistas definem as preferências dos atores políticos às necessidades de obter, manter e aumentar seu poder político pessoal. Supõese que políticos têm interesse básico em poder político, e este interesse é normalmente entendido como derivado das demandas desenhadas a partir do ambiente institucional no qual os atores estão inseridos". Neste caso, então, como o ambiente institucional estudado por Schickler e o deste trabalho são semelhantes, a aproximação se justifica.

De acordo com Schickler (2001, p. 5), cinco tipos de interesses coletivos presentes no Legislativo - diferentes e parcialmente contraditórios - podem motivar o desenho de instituições legislativas e orçamentárias. São eles: i) interesse na reeleição: parlamentares incumbentes tendem a criar e preservar dispositivos institucionais que aumentam suas chances de se reeleger; ii) interesse no Legislativo como ator coletivo: todos os parlamentares estão potencialmente interessados em aumentar a capacidade, poder e prestígio do Legislativo como instituição; iii) interesses nos postos de poder institucional: parlamentares que ocupam posições institucionais de grande poder tendem a querer conservá-las, enquanto os que não têm acesso a essas posições institucionais tendem a querer diminuir as prerrogativas e poderes inerentes a esses postos; iv) interesses partidários: membros do partido majoritário no Legislativo podem discordar de desenhos institucionais que interessem aos integrantes do partido minoritário; v) interesses em políticas públicas: esse tipo de interesse se firma analiticamente na conexão entre instituições e resultados políticos. Certas instituições podem favorecer determinados resultados políticos em detrimento de outros. Assim, discordâncias substantivas (relativas a resultados políticos) de natureza ideológica ou setorial podem dar origem a discordâncias procedimentais (referentes a desenhos institucionais).

Os três primeiros interesses assinalados por Schickler parecem ser razoavelmente universais e podem ser aplicados ao caso brasileiro. No caso deste trabalho, o interesse na reeleição manifesta-se em discussões sobre prerrogativas de emendamento e mecanismos para melhorar a execução das emendas sob a ótica dos parlamentares. A noção de que ter emendas orçamentárias individuais executadas é um dos mais importantes fatores para conseguir a reeleição para o Legislativo (ou continuar a carreira política dentro do distrito eleitoral brasileiro, o estado) é bastante presente 
tanto na literatura acadêmica (Pereira e Rennó, 2003) quanto entre os parlamentares (Carvalho 2003, p. 154-155).

Realizada no primeiro semestre de 2009 sob a coordenação de Cesar Zucco e Timothy Power, a Pesquisa Legislativa Iuperj-Oxford afirma que "visitas às bases aliadas são a atividade mais importante para o futuro eleitoral, tendo sido considerada muito importante por cerca de $90 \%$ dos deputados. Em segundo lugar, mencionada por cerca de $60 \%$ dos legisladores, aparece a apresentação e execução de emendas ao orçamento" ". Mesquita (2009) contesta esta literatura, não encontrando relação direta entre reeleição e execução de emendas. No entanto, conforme afirma Mahoney (2005, p. 318), certo ator político pode ter expectativas pouco condizentes com a realidade empírica (de se reeleger desde que suas emendas sejam executadas, neste caso), mas esta expectativa continuará sendo base para um processo racional de tomada de escolhas.

O interesse no Legislativo como ator coletivo está presente, arrisco dizer, em qualquer parlamento. No caso deste trabalho, este interesse se manifesta mais como recurso retórico, de enquadramento (ver discussão abaixo), do que como fonte de reformas institucionais que efetivamente dariam mais poder ao parlamento como um todo.

Com relação ao interesse nos postos de poder institucional, é o principal interesse associado à organização da Comissão Mista de Orçamento, tema que terá capítulo específico. Trata-se da vontade de manter o acesso a cargos institucionais, internos ao Legislativo, que permitem mobilizar recursos, organizar pequenas coalizões a favor ou contra certa proposta e dialogar com ministros e outros membros do Executivo.

Quanto aos interesses partidários, parece mais frutífero no caso brasileiro substituí-los por interesses referentes ao pertencimento à coalizão. Considerando os períodos democráticos no Brasil, apenas no governo de Eurico Dutra, iniciado em 1945 e estimulado por regras eleitorais desenhadas para beneficiar o PSD (Campello de Souza, 1976), um único partido obteve maioria legislativa a partir das urnas. Outros governos ou foram minoritários ou estabeleceram coalizões de governo mais ou menos estáveis e, após 1988, geralmente bem-sucedidas no que se refere à aprovação de leis

\footnotetext{
${ }^{6}$ http://www.congressoaberto.com.br/plio/atividades-dos-parlamentares/
} 
propostas pelo Executivo (Figueiredo e Limongi, 1999; para a variação entre coalizões, ver Amorim Neto et. al 2003).

Assim, o interesse partidário definido por Schickler pode ser adaptado ao Brasil como interesse referente ao pertencimento à coalizão, pois a clivagem política que define interesses dentro do Legislativo, acesso a postos do Executivo e outros aspectos, é o pertencimento ou não à coalizão formada pelo presidente. Isto não significa que a coalizão é formada sem levar em conta interesses partidários. Ao contrário: são os partidos políticos que resolvem problemas de coordenação entre os parlamentares e o Executivo, organizando demandas políticas diversas e informando deputados sobre as propostas legislativas do Executivo (Figueiredo e Limongi, 1999). No entanto, a divisão do Legislativo em "coalizão" e "oposição" é analiticamente frutífera, dado que embates políticos freqüentemente opõem esses interesses, enquanto interesses de diversos partidos que pertencem à coalizão, por exemplo, tendem a ser mais harmônicos.

Com relação aos interesses em políticas públicas como determinantes de interesses por desenhos institucionais, trata-se de algo que pouco aparece nas discussões sobre reforma orçamentária no Brasil. A manifestação mais visível deste interesse se deu em 2006, quando estava-se discutindo o projeto de resolução 2/2005, do deputado Ricardo Barros, que reformularia parte do processo orçamentário. Diversos parlamentares do PMDB se opuseram à proposta de instituir o rodízio partidário nas relatorias setoriais, ou seja, de mudar, anualmente, o partido responsável por indicar o relator setorial para cada uma das dez áreas temáticas. Se em 2007 o PT, por exemplo, indicou o relator para a área de Ciência e Tecnologia, em 2008 poderia indicar apenas para outras áreas. Acostumado a indicar, ano após ano, o relator para a área de Transportes, o PMDB propôs o rodízio individual nas relatorias: ao partido caberia apenas mudar o parlamentar responsável. Ora, o controle reiterado do PMDB na área de Transportes não pode ser visto como interesse por esta política pública? Autores como Figueiredo e Limongi (2008) crêem que sim, observando que há correspondência entre a ocupação de algumas relatorias setoriais na Comissão Mista de Orçamento e ministérios. No entanto, à exceção do PMDB na área dos Transportes e do PSDB, por alguns anos, na área da Saúde, esta relação não ocorre. Portanto, defendo que este interesse pode ser deixado em segundo plano no estudo de instituições orçamentárias brasileiras $^{7}$.

\footnotetext{
${ }^{7}$ Ao estudar a escolha de instituições orçamentárias na Assembléia Nacional Constituinte no terceiro capítulo, redefinirei alguns desses interesses.
} 
Um dos pontos teóricos mais importantes de Schickler (2001) é que diversos interesses parlamentares, por vezes conflitantes, podem orientar a mesma escolha institucional $^{8}$. O mesmo ocorre nos casos que estudo. A tabela 1.2 abaixo sistematiza os interesses plausivelmente presentes na definição de três instituições, cada uma das quais será tratada em capítulo específico: a prerrogativa de emendamento dos parlamentares, a organização da Comissão Mista de Orçamento e a prerrogativa de o Executivo definir ou não a execução orçamentária ${ }^{9}$.

Tabela 1.2: Interesses parlamentares e desenho de instituições orçamentárias no Brasil

\begin{tabular}{|l|l|l|l|l|}
\hline & Emendamento & $\begin{array}{l}\text { Organização } \\
\text { da Comissão } \\
\text { Mista de } \\
\text { Orçamento }\end{array}$ & $\begin{array}{l}\text { Orçamento } \\
\text { Impositivo }\end{array}$ & $\begin{array}{l}\text { Orçamento } \\
\text { Impositivo } \\
\text { para Emendas }\end{array}$ \\
\hline Reeleição & $\mathrm{X}$ & - & $\mathrm{X}$ & $\mathrm{X}$ \\
\hline $\begin{array}{l}\text { Legislativo como ator } \\
\text { coletivo }\end{array}$ & $\mathrm{X}$ & - & - \\
\hline $\begin{array}{l}\text { Acesso a postos } \\
\text { institucionais }\end{array}$ & - & $\mathrm{X}$ & - & - \\
\hline $\begin{array}{l}\text { Pertencimento à } \\
\text { coalizão }\end{array}$ & $\mathrm{X}$ & $\mathrm{X}$ & $\mathrm{X}$ & $\mathrm{X}$ \\
\hline
\end{tabular}

Forte ênfase será conferida à dimensão temporal dos interesses que orientam o desenho de instituições. Defino os interesses relativos à reeleição, acesso a postos institucionais e pertencimento à coalizão como de curto prazo, enquanto o interesse pelo Legislativo como ator coletivo é de longo prazo. A divisão é assim feita porque o fortalecimento do Legislativo como ator coletivo é algo que ocorre apenas após diversas, sucessivas e acumulativas, decisões que atendem a esse interesse, enquanto decisões institucionais que atendem aos outros três interesses citados não necessitam se acumular para que seus efeitos sejam atingidos ${ }^{10}$. A dimensão temporal é de especial interesse para este trabalho pois, como veremos abaixo, os enquadramentos discursivos mobilizados pelos atores mostram como eles utilizam estrategicamente interesses de longo prazo em seus discursos a fim de minimizar o modo como seus interesses de curto prazo podem ser bem atendidos caso certa decisão seja tomada.

Antes de entrar neste ponto, cabe uma breve revisão sobre a complexa relação entre interesses, idéias e ideologia. Afinal, enquadramentos discursivos (frames) são necessariamente utilizados para atacar ou defender alguma idéia.

\footnotetext{
${ }^{8}$ Schonhardt-Bailey (2006, p. 4) apresenta argumento semelhante.

${ }^{9}$ Caso o Executivo defina, o Orçamento é Autorizativo; caso não define, é Impositivo.

${ }^{10} \mathrm{Ou}$, ao menos, que os atores políticos acreditem que os efeitos desejados são atingidos
} 


\section{1) Interesses, idéias e ideologia}

A relação entre interesses e idéias de atores políticos é essencial para entender dinâmicas institucionais. Nesta seção, farei uma breve resenha da literatura sobre o assunto e proporei que a análise de enquadramentos (frames) discursivos pode elucidar a complicada interação entre idéias e interesses. Para isso, é necessário diferenciar interesses de curto e longo prazo dos atores políticos e utilizar uma definição restrita de idéias.

Adoto a perspectiva citada por Blyth (2003, p. 702), para quem "idéias podem ser vistas como recursos de poder usados por atores que buscam satisfazer seus interesses". Esta perspectiva, associada à linha analítica da escolha racional, limita o papel das idéias e confere prioridade analítica a interesses estruturalmente definidos.

Se é verdade que boa parte da literatura sobre mudanças institucionais e idéias não concorda com a "teoria de interesses" da escolha racional - alguns, como Belánd (2005, p. 10), até afirmam que idéias raramente são mera reflexão de interesses dos atores -, ela é um bom ponto de partida. Blyth (2003, p. 695) resume-a sucintamente: trata-se de considerar que um ator político tem seu interesse "determinado por estruturas". No caso deste trabalho, são os interesses derivados de Schickler (2001) e citados acima (reeleição, Legislativo como ator coletivo, acesso a postos institucionais e pertencimento à coalizão/oposição).

Um parlamentar busca a reeleição porque não só as regras eleitorais permitem, mas porque a estrutura interna do Legislativo o incentiva (Mayhew 1974); um presidente opta por formar coalizões com partidos ideologicamente opostos se dispõe de recursos suficientes, garantidos institucionalmente, para manejar o apoio de grupos políticos heterogêneos (Pereira, Power e Rennó, 2008, p. 12) etc. As instituições, portanto, são construídas para resolver os problemas de ação coletiva resultantes da interação entre atores políticos que buscam maximizar seus próprios interesses.

No entanto, levar isto a sério significa acreditar em equilíbrios induzidos pelas estruturas, sem pistas sobre fatores internos às instituições que podem resultar tanto em estabilidade quanto mudança ${ }^{11}$. A principal resposta teórica a este problema - à exceção de Mahoney e Thelen (2009), citado extensamente acima - foi dada por institucionalistas históricos que recorreram ao uso de idéias para evitar a associação

\footnotetext{
${ }^{11}$ Ver Greif e Laitin (2004) para uma tentativa de explicar mudanças institucionais dentro da linha analítica da escolha racional; para críticas a esta abordagem, ver Mahoney e Thelen (2009, p. 7-8).
} 
automática de atores políticos a seus interesses, assim inserindo motivações nãoestruturais (ideológicas, por exemplo) para explicar o comportamento dos atores.

Vale assinalar a crítica relativa à origem dos interesses dos autores feitas por três institucionalistas históricos bastante citados: James Mahoney, Kathleen Thelen e Peter Hall. Eles apontam a necessidade de desvencilhar idéias e interesses de curto e longo prazo dos atores políticos, embora seja tarefa difícil (Taylor 2008, p. 118). De acordo com Mahoney e Thelen (2009, p. 28), é fundamental separar as motivações para comportamentos de atores a curto e a longo prazo. Um grupo de políticos que concorda atualmente com certa instituição poderá estar bastante interessado em derrubá-la a longo prazo. Algo assim ocorreu quando o Legislativo brasileiro aprovou a Emenda Constitucional n. 32, em setembro de 2001, limitando parcialmente o poder de o Executivo decretar medidas provisórias. Dois interesses dos parlamentares ficaram evidentes neste caso: a curto prazo, participar da coalizão pró-Fernando Henrique Cardoso (1995-2002) e silenciar sobre seu uso de medidas provisórias; a longo prazo, limitar o poder de decreto presidencial e assim fortalecer o Legislativo como ator coletivo. A medida foi aprovada no ocaso do segundo mandato de Cardoso, depois de ele ter feito aprovar a maior parte de sua agenda legislativa ${ }^{12}$.

No mesmo sentido, Hall (1997, p. 197) considera que "a maioria das pessoas têm interesses múltiplos, geralmente associados aos diversos papéis que elas mantêm, alguns conflituosos e muitos dos quais estão sujeitos a interpretações diversas. Diante de certo assunto, um ator pode ter dificuldade em determinar seus interesses... Não é por outro motivo que em relação a importantes questões econômicas de nossos tempos, nem sempre pode ser dito que os interesses de um grupo ou ator político são 'dados' por sua posição socioeconômica. Interesses políticos não devem ser vistos como prédeterminados, mas sim como objeto de incessante contestação"13.

É possível conciliar, parcialmente, as visões da escolha racional e institucionalismo histórico sobre interesses. Dois ajustes podem ser feitas à teoria de interesses da escolha racional considerando as críticas expostas acima. O primeiro é referente ao timing ou perspectiva temporal dos interesses. É frutífero diferenciar interesses de curto e longo prazo dos atores, conforme fiz na seção anterior com os interesses derivados de Schickler (2001). O segundo ajuste é relacionado ao modo como

${ }^{12}$ Sobre os efeitos dessa mudança institucional, ver Pereira, Power e Rennó (2008) e Limongi e Figueiredo (2003). Tratarei dos interesses de curto e longo prazo dos parlamentares brasileiros mais adiante.

${ }^{13}$ Ver também Hall (2005, p. 149-151). 
atores expressam seus interesses. Creio que o enquadramento de idéias tanto revela quanto obscurece interesses, e uma apreensão mais detalhada dos interesses de certo ator em dado momento tem muito a ganhar com a análise dos enquadramentos (frames) discursivos mobilizados por este ator.

Esta conciliação será mais bem-sucedida caso o objeto empírico estudado permita adotar uma definição minimalista de "idéias", desvinculada de conteúdo ideológico. Seguindo Campbell (2004, p. 93), para quem idéias podem ser tanto suposições profundas, ocultas, que orientam o background do debate político quanto as alternativas referentes a policies ou instituições mobilizadas diretamente pela elite política no foreground do debate, opto pela segunda definição, observando que a primeira pode ser facilmente associada a algumas definições correntes de ideologia ${ }^{14}$. Há pelo menos quatro origens possíveis de idéias sobre instituições neste sentido restrito apontado por Campbell, não excludentes entre si: i) interesse determinado por estruturas (perspectiva da escolha racional); ii) experiências institucionais prévias; iii) experiências institucionais em outros países (diffusion) e iv) ideologia.

O primeiro ponto já foi explicado acima. Quanto ao segundo, considero que as idéias institucionais que circulam em critical junctures (Kingdon 1995; Katznelson 2003) levam em conta o modo como certas alternativas institucionais, quando implementadas anteriormente, distribuíram recursos e poder entre atores políticos. Para usar um exemplo do processo orçamentário brasileiro, a prerrogativa de emendar o orçamento durante a Constituinte de 1987-1988 foi avaliada de acordo com como isso afetou a macroeconomia no regime democrático de 1946-1964 ${ }^{15}$, ainda que este diagnóstico tenha sido errado ou incompleto (Ames 1986).

$\mathrm{O}$ terceiro ponto explora um problema de infinite regress que aparece quando se trata de analisar idéias sobre instituições: como as primeiras idéias foram adotadas se não havia antecedentes? Talvez por diffusion. A idéia institucional X distribuiu poder

\footnotetext{
${ }^{14}$ Schmidt (2008, p. 306) propõe distinção semelhante, considerando filosofias, programas políticos e política públicas específicas (philosophies, programs, and policies).

${ }^{15}$ Durante a Assembléia Constituinte de 1987-1988, o ex-ministro da Fazenda Mário Henrique Simonsen foi convocado em reunião conjunta da Comissão do Sistema Tributário, Orçamento e Finanças e da Subcomissão de Orçamento e Fiscalização Financeira, realizada em 30/4/1987. Ele disse: "No que tange à capacidade de o Congresso remanejar verbas e criar novas despesas durante a apreciação da lei orçamentária, minha impressão é a de que se deveria ficar em um meio-termo entre a Constituição Federal de 1946 e a de 1967. A de 1967, certamente, amarrou demais o Legislativo. Em compensação, a Constituição de 1946 permitia que se fizesse algo que não é desejável globalmente, ou seja, criar despesa sem indicar a fonte de financiamento. A meu ver, caso se estabelecesse algo parecido, por exemplo, com o que existe na Constituição alemã, segundo a qual qualquer congressista pode propor despesa, desde que indique a correspondente fonte de receita. Já seria uma melhoria em relação à Constituição de 1967 e um freio contra o excesso de déficit público" (Diário da Assembléia Nacional Constituinte, 1987).
} 
político recursos do modo $\mathrm{Z}$ nos países $\mathrm{A}, \mathrm{B}$ e $\mathrm{C}$ - e por isto é defendida ou rechaçada. Drake (1989) mostra, por exemplo, como o economista Edwin Kemmerer sugeriu instituições macroeconômicas para cinco países da América Latina (Bolívia, Chile, Colômbia, Equador, Peru) em viagens de 1923 a $1931^{16}$. No entanto, para os casos que interessam neste trabalho, a diffusion foi apenas um dos frames legitimadores utilizado por parlamentares na defesa de certa idéia, não tendo originado idéias, mas sim servido para a defesa de idéias existentes por outros motivos. Tratarei deste ponto mais adiante.

A quarta origem plausível de idéias institucionais é a ideologia. É fundamental avaliar se, para o caso empírico estudado, é útil considerar ideologia como uma das origens possíveis de idéias no sentido restrito ${ }^{17}$.

A partir de Bawn (1999, p. 304), podemos imaginar duas funções possíveis para a ideologia. Serve como atalho informacional sobre os comportamentos possíveis dos atores políticos para o eleitorado (Downs 1957) ou como fonte de preferências sobre o assunto Y quando não há interesse presente sobre este assunto, algo que pode ocorrer tanto para a elite política quanto para o eleitorado. Em outras palavras, "ideologia é algo crítico para a política porque causa atores políticos a terem preferências e opiniões sobre assuntos em relação aos quais eles não têm interesse direto" (Bawn 1999, p. 303). Será este o caso de instituições orçamentárias no Brasil?

Embora sejam raros os autores que associem certas escolhas políticas meramente à ideologia dos atores envolvidos (King 1973a e 1973b, p. 423 é um exemplo), parte da literatura sobre instituições orçamentárias associa um conjunto $\mathrm{X}$ de instituições a um efeito fiscal Y (Alesina e Perotti 1996; Heller 1997). Há, assim, um bom argumento a ser feito no sentido de que atores políticos levarão em conta suas preferências fiscais (associadas às suas posições ideológicas) ao escolherem instituições orçamentárias. No entanto, no caso empírico aqui estudado, são parlamentares os atores políticos que optam por certas instituições orçamentárias em vez de outras. As preferências fiscais dos parlamentares terão diminuto papel - se é que terão algum - nesta escolha por dois motivos. O primeiro é que, em presidencialismos, deputados e senadores não são responsabilizados pela situação macroeconômica do país (Cheibub 2006, p. 353; Carreirão 2004, p. 192; Samuels 2004, p. 9). O segundo é que outros interesses dos parlamentares serão mais salientes do que a ideologia neste processo de escolha.

\footnotetext{
${ }^{16}$ Weyland 2007 e Meseguer (2006) são exemplos recentes de análises sobre como idéias se difundem.

${ }^{17}$ Appel (2000, p. 525-530) revisa a literatura que trata da relação entre ideologia e interesses.
} 
Relembrando o raciocínio de Bawn, os atores que realizam escolhas sobre processo orçamentário (parlamentares, neste caso) têm interesse direto nas políticas que podem resultar destas escolhas. Esse interesse é determinado, entre outros motivos, pelo fato de que parlamentares acreditam que emendas orçamentárias são um dos modos de atender eleitores. A hipótese que resulta deste raciocínio é: quando a instituição a ser escolhida não é facilmente associada a "interesses racionais" dos atores que vão escolher a institução, podemos esperar que a ideologia seja razoavelmente importante ${ }^{18}$. Do mesmo modo, o inverso deve se aplicar. Portanto, opto por descartar o papel da ideologia neste trabalho, adotando a restrita definição de Campbell (2004) para pensar em idéias institucionais ${ }^{19}$.

Cabe lembrar agora o argumento de que os diversos interesses de atores políticos os levam a defender idéias institucionais a partir de certos enquadramentos discursivos (frames). O objetivo, de acordo com Blyth (2003, p. 700), é utilizar idéias para “deslegitimizar, contestar e redesenhar" instituições existentes. Ora, para deslegitimizar ou defender uma instituição é necessário falar contra ou a favor dela, e estas falas são frames. Explico, a seguir, o que são enquadramentos (frames), como eles podem ajudar estudiosos que tratam da relação entre idéias, interesses e instituições a analisar a manifestação de interesses de curto e longo prazo, e também como frames são utilizados estrategicamente por entrepreneurs.

\section{2) Enquadramentos discursivos: revelação de interesses e usos estratégicos}

Um cronista brasileiro, famoso por esboçar retratos da classe média brasileira à Woody Allen, escreveu: "Um aristocrata turco esteve na França e apaixonou-se por um vinho branco produzido pelo Chateau Carbonnieux em Bourdeaux. Levou-o para casa e logo o vinho transformou-se no favorito da corte turca. Como o consumo de qualquer bebida alcoólica é proibido pelo Alcorão, criou-se um dilema entre gosto e consciência, criativamente resolvido por um sultão do século dezessete que autorizou a importação do vinho com uma pequena modificação no rótulo. Desde então, as garrafas destinadas

\footnotetext{
${ }^{18}$ Isto ocorre, por exemplo, no trabalho de Appel (2000) sobre privatizações.

${ }^{19}$ Outros atores relativizam o papel da ideologia para escolhas institucionais. Segundo Mahoney (2005, p. 322-323), "é um simples fato que muitas ideologias são colocadas em segundo plano ao competir com interesses mais importantes de atores. $\mathrm{O}$ analista deve avaliar cuidadosamente se a ideologia é realmente fonte de preferência de certo ator, verificando até que ponto suas crenças ideológicas ficam de pé quando convivem com outros interesses. (...) Assim como a maioria dos institucionalistas históricos, favoreço uma abordagem cautelosa na apreciação do poder da ideologia em definir escolhas de atores”.
} 
à Turquia foram denominadas Eau Minerale de Carbonnieux. Depois que o trono foi dessacralizado e ninguém mais pode dizer que governa por designação de Deus, estes pequenos milagres laicos são a onipotência que resta ao governante. Ele pode fazer seu próprio rótulo quando o rótulo verdadeiro é inconveniente" (Veríssimo 1997, p. 85)

O sultão descrito incorreu em algo que atores políticos fazem diariamente: enquadrar um assunto de modo a convencer uma platéia sobre certo ponto de vista. Ele selecionou um aspecto da realidade (o fato de o vinho ser parcialmente composto por água) e tornou-o mais saliente (exibindo-o no rótulo) para evitar um ponto de vista negativo (o vinho como bebida proibida pelo Alcorão). É exatamente a definição de Entman (1993, p. 52) sobre enquadramento, pois envolve seleção e saliência para promover uma definição particular de certo problema a fim de convencer alguém.

O argumento básico que interessa para este trabalho na relação entre idéias, interesses e frames é o seguinte. A posição institucional $\mathrm{K}$ leva um ator político a defender a idéia institucional $X$, pois esta idéia $X$ contém dispositivos que atendem interesses $\mathrm{B}$, de curto prazo, que são inerentes à posição institucional $\mathrm{K}$; esta idéia $\mathrm{X}$ é necessariamente defendida com certos enquadramentos discursivos. Os frames podem explicitar ou ocultar interesses B. Podemos esperar que se uma idéia $\mathrm{X}$ atende muito claramente o interesse do ator, este ator procurará usar frames que ocultam os interesses B. No entanto, se a idéia X não deixa claro imediatamente o interesse B do ator, ele poderá usar frames que poderiam explicitar o interesse B. Ou, no mínimo, não se preocupará tanto em utilizar enquadramentos que ocultam interesses.

Há um ganho teórico em mostrar que não são apenas os interesses associados à escolha racional (interesses de curto prazo definidos na primeira seção, a partir do estudo de Schickler) que são mobilizados em momentos de escolha institucional, pois interesses de longo prazo, revelados por frames também fazem parte da disputa política. Outra contribuição obtida com o estudo de frames é conseguir avaliar a estratégia de atores políticos em critical junctures. Isto será especialmente notado nos capítulos que tratam de dois entrepreneurs ligados ao desenvolvimento de instituições orçamentárias: o senador Antônio Carlos Magalhães e o deputado federal Ricardo Barros.

Enquadramentos têm múltipla utilidade para atores políticos. São uma forma de gerar apoio público para idéias específicas (Béland 2005, p. 11), de legitimar atitudes políticas que podem ser impopulares (Vis e Kersbergen 2007, p. 166; Taylor 2008, p. 
120-123) e inúmeros outros exemplos plausíveis ${ }^{20}$. Mais abstratamente, enquadrar idéias pode ajudar certos atores a "limitar a agenda de alternativas políticas possíveis" (Tuchman 1978, citado por Pan e Kosicki 1993, p. 55) e avançar estratégias. Surpreendentemente, Naurin (2007) estuda como atores utilizam frames mesmo em correspondências privadas com políticos, o que mostra que o debate público não é condição necessária para que haja enquadramentos e estratégias discursivas.

Campbell (2002, p. 27-28) aponta quatro problemas com o uso de enquadramentos para estudar dinâmicas institucionais: i) há poucas provas sobre a "força causal" de enquadramentos; ii) há poucos estudos sobre o processo de enquadrar; iii) pouco sabemos sobre a relação entre enquadramentos e ideologia; e iv) é muito difícil diferenciar enquadramentos "sinceros" e "estratégicos". Os três primeiros não afetam os argumentos deste trabalho. As forças causais que animam dinâmicas institucionais são, como veremos nos próximos capítulos, referentes ao controle da agenda legislativa e outros mecanismos de distribuição de recursos e poder dentro de critical junctures. A maioria dos estudos que trata de processos de enquadramento considera instituições de altíssima saliência no debate público, como globalização (Schmidt 2000; Campbell 2004) e política social (Schmidt 2002, entre outros). Seria importante olhar para instituições menos salientes; creio que este estudo de caso sobre instituições orçamentárias no Brasil pode ser um exemplo, pois, embora relativamente importantes, estão longe de dominar o debate público mesmo durante critical junctures. A relação entre enquadramentos e ideologia não nos interessa: como notei acima, a ideologia tem pouco a ver com escolhas sobre instituições orçamentárias no Brasil. Enquadramentos ajudam a explicar a interação entre idéias e interesses quanto menos a ideologia for importante para entender o caso empírico estudado e quanto mais possível for distinguir interesses de curto e de longo prazo dos atores envolvidos no caso empírico., A relação de enquadramentos com o estudo de instituições políticas que busco apontar é que a seleção de certo aspecto do problema institucional X e a saliência a ele conferida são diretamente relacionadas aos interesses de curto ou longo prazo dos atores políticos que propõem idéias sobre este problema.

Esta seção não tem como objetivo realizar uma extensa revisão da literatura sobre enquadramentos, que combina psicologia social, comunicação, economia e

\footnotetext{
${ }^{20}$ É praticamente impossível, segundo Lieberman (2002, p. 698) e Wagner (2007, p. 3), encontrar uma idéia ou tema que não seja multidimensional; tendo várias dimensões, um ator político qualquer pode explorar apenas uma delas e ignorar as demais.
} 
ciência política. Interessam mais dois aspectos desta discussão, ilustrados com exemplos do influente livro de Riker (1986). O primeiro trata de relacionar diretamente a discussão com interesses e o segundo expõe alguns dos tipos de enquadramentos recorrentes no discurso político, o que antecipa a discussão empírica sobre enquadramentos a ser realizada em diversos capítulos a seguir.

No caso Lincoln at Freeport, Riker (1986, p. 1-9) descreve como, em 1858, Abraham Lincoln debateu contra o senador democrata Stephen Douglas. Era a campanha para que a Assembléia Legislativa de Illinois votasse em um deles para o Senado federal. Sete décadas antes de Lincoln enfrentar Douglas, um acordo durante a assembléia constituinte em Philadelphia tornou a escravidão um assunto a ser tratado por lei estadual, não federal. Ser contra ou a favor da escravidão era um assunto em torno do qual se organizar politicamente.

Em 1846, os democratas do norte, com medo de perder eleições, tornaram-se contra escravidão. Os whigs perceberam que seria melhor descartar sulistas e atrair democratas do norte - assim formando o Partido Republicano. Entre 1868 e 1928, controlaram a presidência por 48 desses 64 anos. Com isso, democratas buscaram tornar escravidão um tema estadual. Stephen Douglas foi importante para que isso acontecesse. Sabendo disso, Lincoln perguntou a ele: "Pode a população de um estado norte-americano, legalmente, contra o desejo de qualquer cidadão norte-americano, eliminar a escravidão sem que haja uma constituição estadual?". Riker chamava de heresthetics a tentativa de um político estruturar algo no mundo - agenda, debate etc. para vencer. Neste caso, como ele afirmou (Riker 1986, p. 8), o propósito de Lincoln era forçar Douglas a se colocar em uma posição difícil para vencer uma de duas eleições: para o Senado estadual imediatamente ou para a presidência norte-americana a longo prazo,

O que Lincoln faz é um enquadramento, pois dá saliência ao aspecto $\mathrm{X}$ (jurisdição federal/estadual) do assunto Y (escravidão), quando poderia ser aspecto $\mathrm{K}$ (direitos civis básicos, como na decisão de 1857 do caso Dred Scott). Lincoln escolheu este enquadramento $X$ pois atenderia tanto a seus interesses de curto prazo - se Douglas respondesse "não", Lincoln seria eleito senador- quanto a interesses de longo prazo, pois se Douglas respondesse "sim", Lincoln teria mais chances para vencer a presidência depois. Este segundo cenário de fato ocorreu. Normalmente, a maioria dos enquadramentos serve a apenas um tipo de interesse do ator político. Lincoln foi genial 
ao encontrar um enquadramento em certa situação que atendesse aos dois tipos de interesse possíveis.

No caso Governeur Morris in the Philadelphia Convention, Riker (1986, p. 3451) relata a invenção do colégio eleitoral norte-americano e a tática dos opositores para derrotar a proposta de o Congresso eleger o Executivo. O primeiro enquadramento utilizado por Morris invocou o papel do Legislativo como ator coletivo, algo ligado à nossa discussão adiante sobre Orçamento Impositivo, e com raízes na filosofia política de Montesquieu. Segundo esse argumento, o Congresso não poderia eleger o Executivo pois isto feriria a doutrina da separação dos poderes e, conseqüentemente, o papel do Legislativo como ator coletivo no sistema político. Se Madison foi persuadido por este enquadramento, algo mais mundano era necessário para convencer políticos de menor estatura intelectual. Segundo Riker (1986, p. 41), Morris associava a eleição do Executivo pelo Congresso à corrupção e intriga política, o que levou apoiadores da idéia parlamentarista a apoiar, enfim, o Colégio Eleitoral. Este exemplo mostra, assim como o anterior, o uso de enquadramentos referentes tanto a interesses de longo prazo (Legislativo como ator coletivo) quanto a interesses de curto prazo (mau funcionamento imediato do sistema político devido à corrupção).

Vale antecipar um dos casos que estudarei ao longo do trabalho, referente à tentativa de instituir o Orçamento Impositivo. Parlamentares utilizaram enquadramentos relacionados a interesses de longo prazo como estratégia retórica para obscurecer interesses de curto prazo, relacionados à reeleição (como a execução de emendas individuais ao orçamento e participação na Comissão Mista de Orçamento). Uma explicação possível para isso é que os interesses de longo prazo - por exemplo, em defesa do Legislativo como ator coletivo - parecem mais legítimos e menos egoístas do que outros. É importante frisar, também, que os enquadramentos dependem fortemente do contexto histórico no qual os atores estão inseridos. Podemos esperar que em uma critical juncture iniciada por causa de um escândalo de corrupção, o enquadramento do tipo "corrupção" seja mais recorrente do que outros, por exemplo.

Frames podem ser divididos, de modo simplificado, em "legitimadores" e “deslegitimadores". Este trabalho observará o uso de, entre outros, frames de "diffusion" e "responsabilidade macroeconômica" como legitimadores e do frame 
"corrupção" ${ }^{21}$ como deslegitimador. Para exemplificar, cabe um exemplo de tentativa de legitimação por diffusion. Em 2005, o deputado federal Virgílio Guimarães defendeu o fim das emendas coletivas de bancadas estaduais ao orçamento afirmando que essa medida "seria mais adequada ao que se pratica na execução de vários outros orçamentos de todo o mundo"22. Trata-se de evocar a experiência de outros países para legitimar uma proposta no Brasil.

Guimarães pertence ao Partido dos Trabalhadores, a sigla que lidera a coalizão governista desde 2003 por se tratar do partido do presidente. Sua defesa do fim das emendas coletivas de bancada estadual faz sentido se considerarmos que membros da oposição podem recorrer a emendas coletivas para compensar a falta de execução de suas emendas individuais ${ }^{23}$. Portanto, o interesse de curto prazo mobilizado pelo deputado é o relativo ao pertencimento à coalizão. O interesse de longo prazo reveladopelo frame usado pelo ator é o Legislativo como ator coletivo, pois o frame de diffusion indica que o parlamentar queira que o Congresso melhore, sendo mais parecido com outros legislativos. A tabela 3 abaixo sistematiza a discussão e indica como o trabalho tratará os frames e interesses mobilizados por parlamentares em relação ao processo orçamentário brasileiro.

Tabela 1.3: Atores, idéias, frames e interesses revelados

\begin{tabular}{|l|l|l|l|}
\hline Ator e idéia & Frame & $\begin{array}{l}\text { Interesse de curto } \\
\text { prazo }\end{array}$ & $\begin{array}{l}\text { Interesse de longo prazo revelado } \\
\text { pelo frame }\end{array}$ \\
\hline $\begin{array}{l}\text { Virgílio Guimarães } \\
\text { (Coalizão) }\end{array}$ & Diffusion & $\begin{array}{l}\text { Pertencimento à } \\
\text { Coalizão }\end{array}$ & Legislativo como ator coletivo \\
$\begin{array}{l}\text { Idéia: fim das emendas } \\
\text { coletivas de bancada } \\
\text { estadual }\end{array}$ & & & \\
\hline
\end{tabular}

Por fim, cabe citar outras três propriedades de frames. A primeira é que eles são "timespecific": ou seja, variam de acordo com os argumentos e informações disponíveis em certo momento. Um exemplo é tratado no livro de Schonhardt-Bailey (2006, p. 4-5) a respeito de escolhas de parlamentares ingleses no século 19 sobre o livre comércio. Em

\footnotetext{
21 Este enquadramento é bastante recorrente no discurso político. Bukovansky (2006) afirma que instituições multilaterais como FMI e Banco Mundial usam este enquadramento de modo inadequado em relação a países em desenvolvimento.

${ }^{22}$ Congresso Nacional. Notas taquigráficas da Comissão Mista destinada a propor a reestruturação do processo orçamentário. 12/4/2005, p. 232-233.

${ }^{23}$ Volto a este ponto adiante.
} 
1846, esses políticos não podiam usar evidências científicas que temos hoje ${ }^{24}$ para apoiar o livre comércio, que à época descontentava eleitores conservadores.

A segunda propriedade de frames é que eles são "policy-specific": ou seja, variam de acordo com os tipos de custos e benefícios que cada política pública mobiliza. O diálogo é com o Lowi (1964) e Wilson (1973). A tabela 1.4 sistematiza este argumento, retirando exemplos de Taylor (2008, p. 50). Algumas regularidades podem ser aventadas, como o frame "impacto econômico negativo" associado a custos e benefícios difusos. Pode ser um primeiro passo a uma teoria sobre frames aplicados a discussões de instituições e políticas públicas.

Tabela 1.4: Frames e características de políticas públicas

\begin{tabular}{|c|c|c|c|c|}
\hline & Benefícios & Custos & Política Pública & Frames \\
\hline I & Concentrados & Concentrados & Reforma Agrária & $\begin{array}{l}\text { Legitimador: direito básico à terra } \\
\text { Deslegitimador: defesa à propriedade } \\
\text { privada }\end{array}$ \\
\hline II & Concentrados & Difusos & $\begin{array}{l}\text { Orçamento para } \\
\text { Educação }\end{array}$ & $\begin{array}{l}\text { Legitimador: direito básico à educação } \\
\text { Deslegitimador: má qualidade do } \\
\text { ensino }\end{array}$ \\
\hline III & Difusos & Concentrados & $\begin{array}{l}\text { Reforma da } \\
\text { previdência }\end{array}$ & $\begin{array}{l}\text { Legitimador: impacto econômico } \\
\text { negativo se SQ for mantido } \\
\text { Deslegitimador: direitos adquiridos }\end{array}$ \\
\hline IV & Difusos & Difusos & Fim da CPMF & $\begin{array}{l}\text { Legitimador: imposto injusto - afeta } \\
\text { mais os pobres } \\
\text { Deslegitimador: impacto econômico } \\
\text { negativo se SQ mudar }\end{array}$ \\
\hline
\end{tabular}

A terceira propriedade de frames é que eles variam de acordo com a saliência do assunto em questão. Exemplifico com o problema de inflação alta. A inflação alta afeta positivamente atores X e Y, com interesses “concentrados” em relação a esta política, lembrando a já citada tipologia de Wilson (1973). A inflação alta afeta negativamente os atores R e T, com interesses "difusos". Podemos esperar que os atores X e Y utilizarão frames legitimadores para defender o não-combate à inflação. No entanto, como os efeitos negativos da inflação alta são extremamente salientes e fácil de serem percebidos pela população em geral (Shiller 1996), os atores X e Y não podem usar esses frames legitimadores abertamente. Por sua vez, o assunto de baixa saliência estudado neste trabalho (instituições orçamentários) permite muitos frames diferentes em circulação no debate público e, portanto, melhor esclarecimento sobre os interesses em jogo.

\footnotetext{
${ }^{24}$ Ver Krugman (1993).
} 
Por fim, a discussão sobre frames e policy types interessa para este trabalho porque as instituições orçamentárias organizam diversas políticas públicas do tipo "beneficios concentrados, custos difusos". Esta é a natureza mesmo de qualquer processo de governança fiscal, definida por Hallerberg, Rainer Strauch e von Hagen (2009, p. 3-4) como o arcabouço institucional que busca resolver o problema common pool das finanças públicas. Governos gastam o dinheiro organizado em um fundo geral de receitas obtidas com a cobrança de impostos dos cidadãos em geral. As receitas são direcionadas, então, a políticas para grupos específicos da sociedade. $\mathrm{O}$ fato de o grupo de pessoas que paga pelas políticas ser muito maior do que o grupo de pessoas que se beneficia das políticas implica divergência entre os benefícios para a sociedade em geral e grupos sociais menores. Esta incongruência é o problema common pool das finanças públicas. Causa pressão nos representantes políticos para aumentar os gastos para essas políticas direcionadas de um modo longe do ideal para a sociedade como um todo, podendo levar a déficits fiscais recorrentes.

Portanto, podemos esperar que os frames associados a políticas do tipo "benefícios concentrados e custos difusos" apareçam também na discussão sobre instituições orcamentárias.

Como já afirmei acima, a segunda contribuição teórica que apresento é a noção de "apoio contingente" às instituições. A linha de escolha racional está correta ao considerar que certos interesses dos atores são "induzidos pelas estruturas", mas falta levar em conta o papel que o funcionamento prático das instituições tem para a manifestação desses interesses. Assim, a idéia de "apoio contingente" inspira-se no "consentimento contingente" de Levi (1990) aliado à compliance institucional de que Mahoney e Thelen (2009) falam. O objetivo é realizar um corretivo teórico à criticada "teoria de interesses" (Blyth 2003) dos analistas de escolha racional, bem como aos institucionalistas históricos que dividem atores de acordo com como eles são afetados por instituições - winners delas se aproveitam, losers lamentam e buscam mudanças. A idéia de "apoio contingente" busca mostrar que to win e to lose é condicional a como as instituições são usadas na prática.

\section{3) Apoio contingente: contribuição às linhas institucionalistas}

Se a relação entre idéias, interesses e frames já exposta serve para pensar o conteúdo de mudanças institucionais, é importante voltar a considerar os processos e atores 
responsáveis por tentativas, bem-sucedidas ou não, de mudanças. $\mathrm{O}$ argumento é que atores políticos podem ter, com certas instituições, uma relação de "apoio contingente", inspirada no que Levi $(1990,1999)$ denomina contingent consent ${ }^{25}$.

Trata-se da decisão de um cidadão de concordar com certos atos do governo apenas se ele considera o governo confiável e se está satisfeito com a concordância recíproca de outros cidadãos a esses mesmos atos. O consentimento contingente trata, portanto, da cooperação com certas regras (instituições orçamentárias, no caso deste trabalho) desde que outros atores (o Executivo e outros parlamentares, no caso deste trabalho) respeitam-nas também.

O ponto básico de Levi (1990) é que a falta de obediência (compliance) de certos atores em relação a uma instituição ou decisão governamental pode ser um driver de mudança institucional. São dois os fatores que podem tornar alguns atores compelidos a não obedecer certo desenho institucional (Levi 1990, p. 410-411). O primeiro é que esses atores podem obter novas informações ou novos recursos de poder de modo a cultivar o interesse em mudar a instituição para conseguir resultados mais favoráveis. O segundo é que a confiança na obediência dos outros atores em relação à instituição pode diminuir drasticamente, sobretudo quando os que mais se beneficiam do desenho institucional vigente são pegos abusando do poder que têm. E isso levaria os outros atores a também desobedecer a instituição.

Mas o argumento de Levi (1990) contém um toque tautológico. Alguns atores podem querer mudar a instituição para dela obter resultados mais favoráveis ou porque sentem que os demais atores não a obedecem satisfatoriamente. Os recursos à disposição desses atores sem dúvida são importantes, mas como a distribuição interna desses recursos mudaria para os atores antes desfavorecidos conseguirem efetuar mudanças institucionais? A autora não fornece resposta ${ }^{26}$.

Um bom complemento pode ser o argumento de Mahoney e Thelen (2009) sobre dinâmicas institucionais, pois, ao mesmo tempo em que consideram fortemente o papel da obediência (compliance) de atores - algo que os aproxima bastante do argumento de

\footnotetext{
${ }^{25}$ Este argumento faz uma importante ligação entre as posições analíticas da escolha racional e do institucionalismo histórico. O ganho teórico em considerar a distribuição de poder e recursos como determinantes para dinâmicas institucionais é compartilhado por poucos estudiosos da escolha racional, como Levi (1990) e Knight (1992).

${ }^{26}$ Em texto bastante recente (Levi 2009), a autora congratula-se por ser uma das poucas analistas de escolha racional que leva em conta a distribuição interna de poder para entender o funcionamento de instituições, mas não elabora como esta distribuição de recursos pode ser alterada de modo a provocar mudanças institucionais.
} 
Levi (1990) -, expõem hipóteses claras sobre os tipos de atores que podem ser levados a não obedecer certa instituição e em que circunstâncias isto ocorre.

\section{1) Vencedores, perdedores e oportunistas}

Esses autores afirmam que a divisão entre vencedores e perdedores com certo desenho institucional é mais fina e relacionada à compliance dos atores em relação a este desenho institucional do que normalmente a literatura considera. Atores diferentes têm incentivos diversos para concordar ou não com certo desenho institucional. Isto varia não só de acordo com a posição institucional de cada ator, como quer a "teoria de interesses" da escolha racional em sua versão mais radical ${ }^{27}$, mas também de acordo com outras relações de poder.

Assim, não é tão frutífero dizer que o ator $\mathrm{X}$ é winner na instituição A enquanto o ator $\mathrm{Y}$ é loser em relação à mesma instituição. Considerando a noção de "apoio contingente", temos que as preferências de atores com interesses divergentes podem ser muito parecidas sobre certa instituição.

Nesse sentido, Mahoney e Thelen (2009, p. 28) afirmam que o "o fato de atores estarem simultaneamente inseridos em diversos desenhos institucionais os torna vencedores em algumas arenas e perdedores em outras. Precisamos de um framework que permita pensar nesses atores como algo além de vencedores e perdedores". A noção de apoio contingente pode ajudar nisso.

Há forte relação desse argumento com o que Mahoney e Thelen (2009, p. 33) chamam de atores políticos “oportunistas”. Eles têm preferências ambíguas - poder-seia dizer contingentes - a respeito da continuidade de certa instituição. Nem buscam preservar ativamente a instituição nem tentam derrubá-la, pois isto implica tempo e custos. Os oportunistas tentam explorar as possibilidades existentes dentro do sistema atual para atingir seus objetivos. Caso a instituição não satisfaça esses objetivos, o apoio dos oportunistas a ela pode se tornar equívoco (Mahoney e Thelen 2009, p. 18) e, talvez, traduzir-se em ações ou para extinguir esta instituição ou para implementar outra a seu lado, o que resultaria em layering institucional. $\mathrm{O}$ argumento sobre o apoio contingente às instituições mostra como relações concretas de poder - freqüentemente

\footnotetext{
${ }^{27}$ Vale lembrar que adoto como os "interesses racionais" dos parlamentares, neste trabalho, os quatro tipos de interesses expostos na segunda seção deste capítulo. A idéia do "apoio contingente" é ajudar a avaliar o "interesse relativo ao pertencimento à coalizão" que os parlamentares brasileiros têm.
} 
determinadas por um conjunto diverso de instituições - provocam certos atores a se comportarem como "oportunistas".

\section{2) Apoio contingente e estratégias do Executivo}

Para este trabalho, considero a interação entre a execução de emendas orçamentárias individuais $^{28}$ e a discricionariedade do Executivo em realizar os gastos previstos por essas emendas (ou seja, o Orçamento Autorizativo) como a dinâmica que sustenta o "apoio contingente" ao desenho institucional. Há três atores políticos envolvidos: parlamentares da coalizão liderada pelo Executivo, parlamentares da oposição e o Executivo.

O Orçamento Autorizativo fornece vantagem distributiva para os membros da coalizão, pois permite que parlamentares pertencentes à coalizão governista tenham mais emendas orçamentárias individuais executadas do que os oposicionistas. Segundo Figueiredo e Limongi (2008, p. 104), “a execução das emendas individuais é pautada por critérios políticos. As emendas dos deputados filiados a partidos da coalizão do governo têm maiores chances de serem executadas do que as dos demais parlamentares. Contudo, parte das emendas de deputados da oposição também é executada e parte das emendas dos parlamentares que votam com o governo não é executada",29.

A crônica jornalística concorda com este diagnóstico. Três exemplos: i) “Apesar de o governo segurar a liberação de emendas, tem privilegiado aliados ao autorizar o pagamento. O Palácio do Planalto favoreceu PMDB, PSB e PT --principais partidos da base governista que articulam candidaturas à Presidência. ....A verba destinada aos aliados é significativamente maior do que a dos dois maiores partidos de oposição ao governo Lula" ${ }^{30}$; ii) "Sabe por que o leão não come o domador, ministro? Porque está bem alimentado", disse o deputado Sandro Mabel (PR) para Paulo Bernardo, ministro do Planejamento, durante reunião para tratar de liberação de emendas ${ }^{31}$; iii) "Como

\footnotetext{
${ }^{28}$ O raciocínio vale, com pequenos ajustes, para a execução de emendas coletivas. Tratarei desse ponto em capítulo específico sobre prerrogativas de emendamento orçamentário.

${ }^{29}$ Esta citação se sustenta mesmo em anos mais recentes, não considerados no livro de Figueiredo e Limongi (2008). De acordo com Perezino (2008), a execução das emendas individuais dos partidos pertencentes à base de sustentação do governo é, na média entre 2004 e 2007, 45\% superior a dos partidos de oposição.

30 "Comissão do Orçamento aprova parecer que amplia para R\$ 12,5 mi emendas individuais" , http://www1.folha.uol.com.br/folha/brasil/ult96u651406.shtml, acessado em 12/11/2009.

${ }^{31}$ Painel, Folha de S. Paulo, 27/8/2009.
} 
medida de austeridade, o governo escolheu sangrar a execução das emendas coletivas neste final de ano. Só $20 \%$ delas serão executadas, somando R\$ 2 bilhões. Normalmente, o percentual fica próximo de 50\%. Nas emendas individuais, o índice de $70 \%$ de execução deve ser mantido" ${ }^{32}$.

Também os parlamentares da oposição afirmam que é esta a estratégia do Executivo. O Instituto FSB Pesquisa consultou 247 parlamentares em pesquisa para a revista Época ${ }^{33}$. É moderadamente negativa a avaliação dos entrevistados sobre o poder do Congresso em influenciar e fiscalizar o orçamento em todas as suas etapas. Para $32 \%$ esse poder é mediano, enquanto para $39 \%$ é baixo ou muito baixo. Entre os parlamentares de oposição, a avaliação foi mais crítica. $34 \%$ deles consideraram que o poder do Congresso em influenciar e fiscalizar o orçamento federal em todas as suas etapas é baixo ou muito baixo, enquanto apenas $12 \%$ dos parlamentares pertencentes à coalizão afirmam o mesmo ${ }^{34}$.

Diversos deputados de oposição reclamam de falta de interesse do governo em liberar suas emendas. Cito dois exemplos para ilustrar: i) Cláudio Cajado, PFL: "É importante termos algum mecanismo que permita que as emendas individuais apresentadas e aprovadas efetivamente sejam liberadas. ....Há dois anos minhas emendas não são liberadas... A pobre cidade de Dias D'Ávila, da qual minha esposa é prefeita, está sofrendo agruras enormes, porque o governo não libera recursos. Faço minha função como deputado, apresento as emendas, divulgo-as e o povo fica a me cobrar. ... O contingenciamento fulmina nossas expectativas" (Comissão 2005, 20/4/2005, p. 59); ii) Deputado Pauderney Avelino, PFL: “Em 2004, o governo usou politicamente o orçamento ao fazer essa elevada execução orçamentária. Isso não pode continuar. Não se pode privilegiar o parlamentar que presta um favor ao governo em detrimento de um deputado ou senador que lhe faz oposição.... Quantos parlamentares vivem de pires na mão, mendigando a liberação de emendas aos ministros? É lamentável! Como não freqüento ministérios e não peço a ministro execução de emenda de minha autoria, não tenho uma emenda executada." (Comissão 2005, 31/3/2005, p. 112).

Finalmente, membros da coalizão também concordam que há o uso de liberação de emendas para lubrificar o comportamento da coalizão em plenário. Dois exemplos

\footnotetext{
${ }^{32}$ Painel, Folha de S. Paulo, 14/10/2008.

${ }^{33}$ Agradeço Leandro Loyola, editor-assistente da revista, por disponibilizar esses dados.

${ }^{34}$ Instituto FSB Pesquisa. "Pesquisa de Opinião no Congresso Nacional". Brasília, junho de 2009, mimeo, p. 13-14.
} 
para encerrar: i) "Se depender da área econômica do governo, as emendas apresentadas pelas comissões do Senado são grandes candidatas à tesourada no decreto de contingenciamento do Orçamento que está sendo preparado. $\mathrm{O}$ valor dobrou de $\mathrm{R} \$ 1,3$ bilhão em 2008 para R \$ 2,6 bilhões em 2009. Mas líderes governistas lembram que é no Senado que Lula tem sua base mais frágil" 35 ; ii) Fernando Henrique Cardoso, expresidente: "No passado, as crises financeiras eram tão prementes e a escassez de recursos, de tal monta, que o governo federal tinha de 'contingenciar' as verbas orçamentárias e ia liberando a conta-gotas. O que mudou? Mudou que hoje os recursos são mais abundantes e a discricionariedade partidária no momento das liberações das verbas aumentou, levando muitos parlamentares a buscar o aconchego das maiorias governamentais. A essência da distorção é a mesma: o que está escrito e aprovado no orçamento só vale se o Executivo concordar em liberar. Consequentemente, quem tiver força junto ao governo será um 'pistolão' cobiçado pelos fazedores de obras e de negócios. Mas a gravidade da situação a que se chegou é muito maior" ${ }^{\text {"36. }}$

Além disso, o Orçamento Autorizativo, de acordo com parte da literatura, fornece vantagem estratégica para Executivo, pois este consegue calibrar a execução orçamentária de modo a extrair maior apoio no plenário para suas propostas legislativas (argumento sustentado por Alston e Mueller 2005 e Pereira, Power e Raile 2009; Figueiredo e Limongi 2008 discordam).

Quanto menos o Orçamento Autorizativo se traduzir em uma razoável execução de emendas orçamentárias individuais, menos incentivos os parlamentares (tanto da coalizão quanto da oposição ao Executivo) terão para apoiar esta instituição.

A tabela 1.5 sistematiza as quatro estratégias possíveis do Executivo com relação à liberação de verbas, os resultados conseqüentes e o apoio ao status quo institucional dos parlamentares de acordo com os efeitos das instituições. Trata-se de imaginar cenários contrafactuais para melhor avaliar o funcionamento institucional.

\footnotetext{
${ }^{35}$ Painel, Folha de S. Paulo, 10/1/2009

${ }^{36}$ Cardoso, Fernando Henrique. "Corrupção, voto e orçamento", O Estado de S. Paulo, 3/6/2007, p. A2.
} 
Tabela 1.5: Estratégias possíveis do Executivo e apoio às instituições orçamentárias ${ }^{37}$

\begin{tabular}{|l|l|l|}
\hline & Payoff para Executivo & Apoio ao Status Quo \\
\hline $\begin{array}{l}\text { I: Alta liberação para } \\
\text { Coalizão e para Oposição }\end{array}$ & $\begin{array}{l}\text { Economicamente "alto", } \\
\text { politicamente baiixo }\end{array}$ & $\begin{array}{l}\text { Coalizão: Forte } \\
\text { Oposição: Forte }\end{array}$ \\
\hline $\begin{array}{l}\text { II: Alta liberação para } \\
\text { Coalizão, Menor para } \\
\text { Oposição }\end{array}$ & $\begin{array}{l}\text { Economicamente "alto", } \\
\text { politicamente razoável }\end{array}$ & $\begin{array}{l}\text { Coalizão: Forte } \\
\text { Oposição:Fraco/Médio }\end{array}$ \\
\hline $\begin{array}{l}\text { III: Alta liberação para } \\
\text { Oposiçao, Menor para } \\
\text { Coalizão }\end{array}$ & $\begin{array}{l}\text { Economicamente "alto", } \\
\text { politicamente baixo }\end{array}$ & $\begin{array}{l}\text { Coalizão: Fraco } \\
\text { Oposição: Forte }\end{array}$ \\
\hline $\begin{array}{l}\text { IV: Baixa liberação para } \\
\text { Coalizão e Oposição }\end{array}$ & $\begin{array}{l}\text { Economicamente "baixo", } \\
\text { politicamente baixo }\end{array}$ & $\begin{array}{l}\text { Coalizão: Forte } \\
\text { Oposição: Fraco }\end{array}$ \\
\hline
\end{tabular}

A primeira estratégia possível para o Executivo - liberar muita verba tanto para parlamentares da coalizão quanto da oposição - renderia forte apoio ao status quo orçamentário (ou seja, Orçamento Autorizativo + Emendas Individuais) por parte de ambos os grupos no Legislativo. No entanto, o payoff para o Executivo não seria bom. Aconteceria algo semelhante ao que Thaler (1988) denomina “winner's curse". Isto ocorre quando uma pessoa paga $\mathrm{X}+20$ por um quadro em um leilão quando poderia ter pago $\mathrm{X}+10$, pois seu objetivo, o de assustar outros potenciais compradores, já seria atingido com $\mathrm{X}+10$. O Executivo pode incorrer em uma espécie de "winner's curse" caso libere mais verbas do que o necessário para garantir apoio em plenário.

A segunda estratégia é a que de fato ocorre no sistema político brasileiro atualmente. Ao longo do tempo, o Executivo percebeu que se executar cerca de $70 \%$ das emendas da coalizão e $40 \%$ das emendas da oposição consegue apoio (contingente) às instituições orçamentárias e apoio razoável em plenário ${ }^{38}$. Nunca é demais dizer que há diversos outros fatores que influenciam o apoio de parlamentares a projetos do Executivo em plenário, provavelmente tão ou mais importantes do que a liberação de emendas. No entanto, não se pode ignorar o papel do processo orçamentário ao menos na tentativa de unir a coalizão pró-governo.

Quanto à terceira estratégia possível, de alta liberação das emendas propostas por parlamentares de oposição e menor para as emendas da coalizão, seria plausível caso o Executivo cimentasse a coalizão em plenário com outros side payments, como

\footnotetext{
${ }^{37}$ Identifiquei as três primeiras estratégias como de payoff econômico relativamente alto, entre aspas, para o Executivo pois já está bastante consolidado na literatura sobre o orçamento brasileiro que a liberação de verbas para emendas individuais é algo que está longe de afetar a política macroeconômica substantivamente.

${ }^{38}$ Em momentos de votações importantes ou crises políticas, o Executivo pode se ver incentivado a aumentar o percentual de execução. Inversamente, em momentos de grande apoio popular etc., o Executivo pode diminuar esse percentual sem prejuízo aparente.
} 
cargos em ministérios, na burocracia federal etc. Mas o ganho político dessa estratégia seria relativamente baixo, pois a mera execução de emendas provavelmente não seria suficiente para implementar a agenda legislativa do Executivo com apoio dos partidos da oposição. Mudanças nesta agenda legislativa seriam exigidas e a negociação se daria mais em termos substantivos, específicos a cada política pública, do que em termos de pork.

A quarta estratégia possível, de baixa liberação para as emendas tanto da coalizão quanto da oposição, apenas reforçaria a necessidade de o Executivo realizar outros tipos de side payments e/ou concessões substantivas na legislação para aprovar as leis desejadas.

O sistema atualmente funciona conforme expus acima - o Executivo libera mais verbas para os parlamentares da coalizão do que para os da oposição -, mas isto decorre puramente de uma estratégia dos presidentes para cimentar coalizões. Ou seja, caso fosse outra a estratégia, parlamentares da coalizão poderiam ter poucos motivos para apoiar o status quo de instituições orçamentárias. O apoio é, afinal, contingente. Este argumento é fundamental para entender como os parlamentares mobilizam seus interesses contra ou a favor de instituições orçamentárias. Ao entender os mecanismos que sustentam o interesses $\mathrm{X}$ em vez de $\mathrm{Y}$, os motivos pelos quais uma instituição se mantém enquanto outra se desmancha tornam-se mais claros.

\section{3) Breve explicação dos capítulos}

Todos os capítulos a seguir estão relacionados à discussão teórica desenhada acima. $\mathrm{O}$ capítulo 2 indica três critical junctures relacionadas a instituições orçamentárias brasileiras: a Assembléia Constituinte de 1987-1988, o período pós-CPI de 1994-1995 e a época de 2005-2006. Ainda que Mahoney e Thelen (2009) frisem a importância de processos graduais de mudança institucional, é inegável que critical junctures permitem que circulem de modo bastante livre as idéias institucionais que informam esses processos. Portanto, defini-las e analisá-las com rigor é fundamental.

A escolha de instituições orçamentárias pela Assembléia Nacional Constituinte de 1987-1988 é o tema do capítulo 3. Trata-se de uma critical juncture na qual os interesses legislativos tratados acima (reeleição, acesso a postos institucionais, pertencimento à coalizão/oposição, Legislativo como ator coletivo) têm peso diferente em relação aos outros períodos analisados. Ao inserir as escolhas de instituições 
orçamentárias na lógica do processo constituinte, entende-se por que certas instituições da ditadura militar foram mantidas (por exemplo, a Comissão Mista de Orçamento) e outras foram resssuscitadas, parcialmente, do regime democrático de 1946-1964 (por exemplo, a prerrogativa de parlamentares emendarem o orçamento).

O capítulo 4 aborda as escolhas pós-constituinte a respeito das instituições que regulam o emendamento orçamentário e o capítulo 5 trata da organização da Comissão Mista de Orçamento. As critical junctures de 1994-1995 e 2005-2006 são analisadas detalhadamente em ambos os capítulos, identificando todas as idéias em circulação e quais interesses - revelados ou não por frames - informam essas idéias. Os dois casos são associados a processos de mudança institucional analisados por Mahoney e Thelen (2009) - layering para as emendas, conversion para a comissão orçamentária.

A estabilidade do Orçamento Autorizativo no Brasil é analisado no capítulo 6, que pode ser visto como um caso complementar aos demais, pois trata do que Cappocia e Kelemen (2007) chamam de "near miss": uma quase mudança institucional. Os frames utilizados pelo empreendedor Antônio Carlos Magalhães, principal defensor do fim do Orçamento Autorizativo, revelam quais interesses legislativos estiveram presentes na decisão de manter essa instituição. 


\section{Capítulo 2}

\section{Escolhas institucionais em critical junctures}

A análise da evolução de regras orçamentárias no Brasil ao longo das duas últimas décadas exige olhar cuidadoso sobre os momentos críticos nos quais decisões importantes a respeito dessas instituições foram seriamente consideradas e descartadas ou aprovadas. Nesses momentos, aqui chamados de critical junctures, rigorosamente definidos por Capoccia e Kelemen (2007), supõe-se que atores políticos realizam decisões com fortes conseqüências para o desenrolar do jogo orçamentário nos anos seguintes. É fundamental, assim, definir como o poder político foi distribuído em cada uma das critical junctures em análise para entender por que a decisão $\mathrm{X}$ e não $\mathrm{Y}$ foi tomada.

O estudo dessas decisões internas às critical junctures tem muito a ganhar com a abordagem da "narrativa analítica", que modela as opções e decisões, à escolha racional, sem desconsiderar o contexto estrutural em que elas foram tomadas, à institucionalismo histórico. A narrativa analítica serve também para ligar as diversas critical junctures dispersas no tempo.

Este capítulo é um preâmbulo metodológico aos capítulos que tratam, respectivamente, das escolhas sobre emendamento orçamentário, organização da Comissão Mista de Orçamento e natureza da execução orçamentária (ou seja, Orçamento Autorizativo vs. Impositivo) tomadas nos últimos vinte anos. Há dois grandes argumentos a serem explicitados neste capítulo. O primeiro é relacionado, como já disse, à distribuição do poder político nas critical junctures durante as quais escolhas sobre instituições orçamentárias foram seriamente consideradas no Brasil. Em outras palavras, é importante observar quais grupos controlaram a agenda legislativa nestas critical junctures para entender quais resultados institucionais foram obtidos em vez de outros. O segundo argumento trata da definição das preferências dos atores que podem controlar a agenda das CJs, utilizando o modelo da "narrativa analítica".

O capítulo está dividido do seguinte modo. Na próxima seção, defino os períodos de 1987/1988, 1994/1995 e 2005/2006 como critical junctures de escolhas sobre instituições orçamentárias brasileiras. Em seguida, modelo as escolhas dos atores pertencentes à coalizão e à oposição dentro de narrativas analíticas, expondo as escolhas 
institucionais realizadas e o contexto estrutural das critical junctures nos quais elas se deram.

\section{(1) Critical junctures: 1994/1995 e 2005/2006}

A primeira perspectiva analítica usada por institucionalistas para estudar mudanças institucionais foi a do punctuated equilibrium, inspirada em conceitos da biologia. Seguindo Krasner (1984, p. 324), esta perspectiva pode ser descrita como a de que estruturas institucionais não respondem de maneira imediata, fluida e incremental a alterações no ambiente. Mudanças são vistas como raras, difíceis, e dramáticas, e não como contínuas e incrementais. Crises políticas são catalisadoras e, uma vez findas, os arranjos institucionais que delas resultam tendem a permanecer se reproduzindo, respondendo mais aos incentivos gerados endogenamente do que a fenômenos externos.

Esta linha argumentativa tem pelo menos três limitações. Diz pouco sobre os mecanismos de reprodução em marcha que permitem, no fim das contas, que certa instituição se mantenha ao longo do tempo; subestima a capacidade de instituições mudarem pouco ou de maneira gradual; por fim, frisa a centralidade de critical junctures sem explicitar quando podemos esperar que eles ocorram, sem afirmar se o momento crítico se dá por conta de um motivo único ou pela conjunção de vários processos. No entanto, progresso tem sido feito em relação a este último item.

A clássica definição de Collier e Collier (1991, p. 30) - "uma critical juncture é um momento de mudança significativa, que varia de acordo com cada país (ou outra unidade de análise) e produz legados diferentes" - foi recentemente superada. O rigoroso ensaio de Capoccia e Kelemen (2007, p. 352) argumenta que apesar da tentação em equacionar CJs com mudança, este argumento não é condizente com a ênfase em continuidades estruturais e contingência aguçada que definem CJs.

Afinal, se uma instituição X passa por uma critical juncture em que pode se tornar X1 ou X2, por que não poderia permanecer X? Um exemplo é o da existência da Comissão Mista de Orçamento. A Comissão Parlamentar de Inquérito concluída em 1994 sugeriu o fim da comissão, algo que não foi acatado ao fim da critical juncture em setembro de 1995, com a aprovação da Resolução 2/1995.

Apesar dessa discórdia, há razoável consenso entre analistas que critical junctures são períodos nos quais idéias e propostas circulam mais livremente, permitindo que atores "experimentem, testem, aprendam e explorem diversas 
alternativas" (Katznelson 2003, p. 282), estando mais abertos a elas. Trata-se de momentos parecidos com o que Kingdon (1995, p. 194-5) denomina policy windows, abertas com a "aparição de problemas urgentes ou acontecimentos repentinos no meio político". Podem ser úteis para oxigenar a circulação de idéias, abrindo espaço para que idéias heterodoxas circulem. Afinal, conforme Majone (1989, p. 36) afirma, há uma inércia intelectual e institucional que confere enorme vantagem às idéias condizentes com práticas e arranjos já em vigor. As critical junctures permitem também a mobilização de muitos tipos de frames discursivos, que permitem distinguir interesses de curto e longo prazo dos atores políticos. Nos capítulos empíricos a seguir, analisarei as agendas iniciais de idéias em circulação nas critical junctures e como foram adotadas ou não pelos atores com poder de decisão.

Apesar da importância do conceito para a literatura sobre políticas públicas e desenvolvimento institucional, havia a necessidade de definir com rigor o que caracteriza uma critical juncture. Capoccia e Kelemen (2007, p. 348) realizam bem essa tarefa, definindo as CJs como "períodos de tempo relativamente curtos, durante os quais há uma probabilidade significativamente maior de que as escolhas dos atores afetarão o resultado político que interessa estudar". Esclarecem que o período é "relativamente curto" pois a duração da CJ deve ser breve se comparada ao processo de reprodução institucional que a sucede. Com relação à "probabilidade significativamente maior" de que as escolhas terão grande impacto, afirmam que tanto antes quanto depois da CJ escolhas semelhantes não teriam impacto comparável.

A importância de definir a unidade de análise para avaliar se uma juncture é critical não deve ser subestimada. No exemplo brasileiro, se a unidade de análise for "regras macroeconômicas", as critical junctures podem estar em 1986, 1988, 1994/1995, 2000/2001, 2003. Se a unidade de análise for "regras orçamentárias", como no caso deste trabalho, as possíveis critical junctures são 1988, 1991, 1993, 1995, 2001 e 2006. Trata-se de datas nas quais resoluções congressuais foram analisadas e aprovadas, à exceção de 1988, quando a Constituição Federal foi promulgada.

As resoluções são relevantes pois indicam a manutenção ou mudança das regras que regulamentam a tramitação legislativa do orçamento. Divido-as em abrangentes (1/1991, 2/1995, 1/2001, 1/2006), modificadoras (1/1993) e excepcionais (1994, 1998, 2000, diversas em 2003). A necessidade de estabelecer regras básicas para a tramitação legislativa do orçamento motivou a Resolução 1/1991 e a implementação da Lei de 
Responsabilidade Fiscal, em 2000, provocou a Resolução 1/2001 ${ }^{39}$. As Resoluções de 1991 e 1993 não resultaram de critical junctures pois foram revistas em 1994 e o ambiente economico era muito instável, pouco propício a regras duradouras. A Resolução 1/2001, por sua vez, não pode ser considerada resultado de critical juncture pois o debate em torno de instituições fiscais em 2001 limitou-se a uma parte pequena do processo orçamentário, ligada à Lei de Responsabilidade Fiscal ${ }^{40}$.

Os momentos que considero críticos para a análise das prerrogativas de emendamento orçamentário e da organização da Comissão Mista de Orçamento são 1987-1988, 1994-1995 e 2005-2006 ${ }^{41}$. A primeira, por se tratar da Assembléia Nacional Constituinte, merecerá capítulo e explicações à parte. As duas últimas critical junctures têm forte relação com escândalos de corrupção. A vantagem em analisar ambas está no fato de que os atores envolvidos, as instituições em debate e os mecanismos de controle da agenda política são extremamente semelhantes, mas os resultados foram diferentes. Nos parágrafos a seguir, realizo uma breve contextualização dos momentos históricos que antecederam ambas as critical junctures consideradas neste capítulo.

Antes de 1995, o processo orçamentário brasileiro oscilava entre a irrelevância pois a hiperinflação tornava os gastos extremamente difíceis de controlar e estimulavam brigas entre ministérios, como mostra Pinheiro (1996) - e a corrupção - pois, como mostro em outro capítulo, de 1988 a 1993 ocorreu danosa captura corrupta da Comissão Mista de Orçamento por um grupo de parlamentares. Uma comissão parlamentar de inquérito (CPI) foi instalada em outubro de 1993 para investigar o enriquecimento por meios ilícitos de alguns integrantes da Comissão Mista de Orçamento. Com duração de três meses, a CPI investigou 43 parlamentares. 14 foram inocentados, mais investigações foram sugeridas para 11 e 18 tiveram a cassação recomendada ${ }^{42}$. Quatro parlamentares renunciaram e seis foram cassados.

\footnotetext{
${ }^{39}$ As principais inovações da Resolução 1/2001 foram extinguir as subcomissões temáticas permanentes da CMO, estabelecer que o valor global das emendas individuais será definido anualmente no parecer preliminar do relator-geral da comissão e estender à comissão o exame dos créditos extraordinários abertos por medida provisória.

${ }^{40}$ Ver Loureiro e Abrucio (2004, p. 59-63).

${ }^{41}$ A critical juncture de 1994-1995 iniciou-se em Janeiro/1994, quando a CPI do Orçamento publicou seu relatório, e encerrou-se em Setembro/1995, com a promulgação da Resolução 2/1995. A critical juncture de 2005-2006 iniciou-se em Março/2005, com um ofício do presidente da Comissão Mista de Orçamento pedindo reformas em certas instituições orçamentárias, e encerrou-se em Novembro/2006, com a promulgação da Resolução 1/2006.

${ }^{42}$ A lista dos parlamentares, com os "anões do orçamento" em itálico, é: os deputados federais Anníbal Teixeira (PTB-MG); Carlos Benevides (PMBD-CE); Cid Carvalho (PMDB-MA); Daniel Silva (PPRMA); Ézio Ferreira (PFL-AM); Fábio Raunheitti (PTB-RJ); Feres Nader (PTB-RJ); Flávio Derzi (PPMS); Genebaldo Correia (PMDB-BA); Ibsen Pinheiro( PMDB-RS); João Alves de Almeida (expulso do
} 
Em janeiro de 1994, o relatório final da CPI do Orçamento sugeriu 23 mudanças referentes ao processo orçamentário. Na mesma época, o governo federal preparou e implementou diversas medidas macroeconômicas com o intuito de acabar com a hiperinflação no Brasil - mais notadamente o Plano Real em julho de 1994.

O parecer preliminar do relator-geral do orçamento para 1994 - a peça legislativa mais relevante para o processo além da própria lei orçamentária -, que deveria ter sido aprovado no fim de 1993, foi aprovado apenas no fim de agosto de 1994. O relator-geral daquele ano, Luiz Carlos Santos (PMDB, coalizão), desabafou: “Amanhã se inicia o mês de setembro. Até que a lei orçamentária seja sancionada, estaremos na segunda metade do mês de outubro, ocasião em que o orçamento de 1994 já estará com cerca de $80 \%$ de suas dotações executadas. Portanto, seria temerário introduzir modificações na proposta sob apreciação, ressalvado para a correção de erros ou omissões, dado que alterações programáticas, a esta altura, ou não teriam qualquer consequiência prática por inexistir tempo útil para sua implementação - além de ser de questionável racionalidade e legitimidade que se iniciem novos empreendimentos no último ano de uma administração - ou tumultuariam ainda mais a execução orçamentária neste final de ano"

Em novembro de 1994, a Resolução 2/1994 foi aprovada às pressas para tratar das regras do orçamento do ano seguinte. Foi uma resolução de transição, cujo objetivo era assegurar as preferências do Executivo no processo orçamentário até Fernando Henrique Cardoso, ex-ministro da Fazenda, eleger-se presidente e seu Plano Real se consolidar.

Outra citação do relator-geral mostra como este processo intermediário foi caótico: "Tendo em vista os sucessivos atrasos na apreciação do orçamento de 1994, causados pelas várias propostas de modificação encaminhadas pelo Executivo, preocupou-se o Congresso em tornar mais expedita a sua apreciação, instituindo, através da Resolução 2/1994, rito sumário para a tramitação de tal projeto de lei. Na prática,

PPR-BA); João de Deus Antunes (PPR-RS); José Geraldo Ribeiro (PMDB-MG); Manoel Moreira ( PMDB-SP); Paulo Portugal (PP-RJ); Raquel Cândido (PTB-RO); Ricardo Fiúza( PFL-PE) e o senador Ronaldo Aragão (PMDB-RO). Além disso, sugeriu mais investigações para onze congressistas: os deputados federais Gastone Righi (PTB-SP); José Carlos Aleluia (PFL-BA); José Carlos Vasconcellos $(P R N-P E)$; José Luiz Maia (PPR-PI); Messias Góis (PFL-SE); Mussa Demes (PFL-PI); Paes Landim (PFL-PI); Pinheiro Landim (PMDB-CE); Roberto Jefferson (PTB-RJ); Uldurico Pinto (PSB-BA) e o senador Dario Pereira (PFL-RN).

43 Parecer de Plenário em Substituição à CMO, sobre o projeto de lei n. 23 de 1993 (CN), com as modificações introduzidas pelas mensagens n. 112, 160, 161 e 201, de 1994 (CN), de iniciativa do Poder Executivo, que "estima a receita e fixa a despesa da União para o exercício financeiro de 1994". 31/agosto/1994. 
entretanto, os fatores conjunturais que cercam um ano eleitoral acabaram interferindo no calendário de apreciação dos relatórios setoriais das subcomissões da Comissão Mista de Orçamento e impossibilitando ao relator-geral realizar suas incumbências".

A Resolução 2/1994 previa os seguintes procedimentos: i) inaplicabilidade ao projeto de lei em apreciação das normas relativas ao parecer preliminar, relatorias parciais e setoriais - ou seja, tramitação "expressa" da lei orçamentária; ii) redução drástica dos prazos com a adoção de rito sumário para apresentação, discussão, votação, sistematização e publicação das emendas e do parecer; iii) elaboração conjunta do parecer, na forma de colegiado constituído pelo relator-geral e de sete relatores adjuntos, ficando assegurados aos partidos cujas representações não tenham contribuído para a composição do quadro de relatores-adjuntos o direito de indicar observador para acompanhar os trabalhos da relatoria. (....); iv) realização de audiências públicas com membros do Executivo a fim de obter elementos que subsidiem a análise da proposta ${ }^{44}$. Este último item, sobretudo, demonstra a interferência - pouco importa se bem-vinda ou não pelos parlamentares - do Executivo no processo orçamentário daquele ano, algo que não ocorreu de 1988 a 1993.

Em fevereiro de 1995, os presidentes da Câmara dos Deputados e Senado Federal instalaram um grupo de trabalho para rever as regras orçamentárias, liderado pelo senador José Fogaça (PMDB). A resolução congressual proposta por este grupo foi aprovada em setembro de 1995, a tempo de regulamentar o processo que resultou no orçamento para 1996. Há grande consenso na literatura de que esta Resolução 2/1995 resultou da CPI (Vieira 2008, p. 16; Figueiredo e Limongi 2008, p. 49). Mostrarei, nos capítulos empíricos sobre prerrogativas de emendamento e a organização da Comissão Mista de Orçamento, em que medida a CPI influenciou as escolhas institucionais.

Em março de 2005, um ofício do deputado federal Paulo Bernardo (então presidente da Comissão Mista de Orçamento) enviado para os presidentes da Câmara dos Deputados e Senado Federal tratava de diversos temas relativos à reforma orçamentária $^{45}$. Bernardo diagnosticou um "distanciamento da execução orçamentária em relação à autorização legislativa expressa na lei orçamentária, dada a idéia de que o

${ }^{44}$ Congresso Nacional. Comissão Mista de Orçamento. Parecer Final (Relatório Relator-Geral) da Comissão Mista de Orçamento sobre o Projeto de Lei n. 3 de 1994 (CN) de iniciativa do Poder Executivo que "estima a receita e fixa a despesa da União para o exercício financeiro de 1995". Autores: Gilberto Miranda e diversos relatores-adjuntos, que são: senador Carlos Patrocínio; deputado Joao Faustino; deputado Roberto Balestra; deputado Vadão Gomes; deputado João Almeida; deputado Oswaldo Coelho; senador Ronan Tito. 2 de dezembro de 1994.

${ }_{45}$ Agradeço Carlos Marshall, consultor de orçamento do Senado Federal, por me encaminhar este documento. 
orçamento aprovado tem caráter autorizativo" e um "contingenciamento discricionário da execução orçamentária". A partir deste ofício, uma comissão de deputados e senadores foi encarregada de organizar reuniões com membros do Executivo e parlamentares em geral sobre diversos itens da reforma orçamentária. Esta comissão não teve sucesso em formar consenso em torno de uma proposta de mudança de regras orçamentárias, apesar do aparente esforço do relator Ricardo Barros (PP, oposição).

Sobre seu relatório final, Barros afirmou: "Meu relatório, feito com a ajuda da consultoria e de outros colegas que têm participado com frequiência do trabalho, acatou, das 412 emendas, 111 integralmente e 138 parcialmente. Portanto, acatamos quase $70 \%$ do que foi proposto como alteração. É um relatório bastante democrático, e o substitutivo praticamente atendeu ao que foi proposto e não era conflitante com o pensamento da maioria" (Congresso Nacional 2005, 24/5/2005, p. 253). Uma semana depois, suplicou: "Faço um apelo para que ponderem. Muitos cederam aqui, e muitos foram atendidos. A maioria cedeu um pouco e foi atendida um pouco nos seus posicionamentos. Queria que, na hora de votarmos a matéria, isso fosse considerado. É evidente que todos não podem ser atendidos em tudo. Uns queriam acabar com as emendas de comissão, outros queriam aumentá-las; uns queriam acabar com as emendas de bancada, outros queriam aumentá-las. Então não há como atender totalmente posições divergentes". (Congresso Nacional 2005, 31/5/2005, p. 277). A critical juncture de 2005-2006, iniciada com a instalação desta comissão relatada por Barros, terminou com a aprovação da Resolução 1/2006 em novembro daquele ano, detalhada adiante.

A fim de observar com mais rigor se esses dois períodos foram mesmo critical junctures, sigo a sugestão de Capoccia e Kelemen (2007, p. 343), segundo os quais o analista deve empregar tanto a análise contrafactual quanto a narrativa analítica para justificar suas escolhas.

Segundo Mahoney (2000, p. 513), os estudiosos devem focar uma "escolha contrafactual" -- que estava de fato disponível durante certa critical juncture e, de acordo com as expectativas teóricas, deveria ter sido adotada - pois talvez haja evidência empírica suficiente para permitir especulações plausíveis e bem fundamentadas ao menos sobre as consequiências de outras decisões que poderiam realisticamente terem sido tomadas.

Quais podem ser essas "escolhas contrafactuais" nos dois períodos que, eu defendo, são critical junctures para instituições orçamentárias brasileiras? Em 1994- 
1995, o antecedente contrafactual pode ser a não-instalacao da CPI do Orçamento em 1992 por conta do controle da Mesa Diretora por parlamentares envolvidos no esquema. É bastante plausível que isso teria ocorrido também no fim de 1993 se não fosse a contingência do assassinato da mulher de um alto burocrata do processo orçamentário, algo que deu enorme publicidade midiática aos escândalos dos "anões do orçamento" ligados a este burocrata. A decisão de não criar a CPI inicialmente é bem relatada por Krieger et. al (1994, p. 9-14): “11 de maio de 1992. A decisão a ser tomada na reunião congressual era: criar ou não criar uma Comissão Parlamentar de Inquérito para investigar as denúncias de irregularidades na Comissão Mista de Orçamento do Congresso. Uma decisão tão importante que exigira a reunião das mesas diretoras da Câmara e do Senado. (p. 10) Por motivos semelhantes, o presidente da Câmara, Ibsen Pinheiro, e o do Senado, Mauro Benevides, sabiam que a CPI não podia existir. Mais que o Congresso, eram os próprios segredos que eles precisavam proteger. (...) A avalanche de denúncias tinha começado em outubro de 1991. Foi nessa época que os jornais descobriram o deputado João Alves como um personagem interessante. Dezenas de reportagens com denúncias tinham se repetido nos jornais e na $\mathrm{TV}$, martelando a imagem do Congresso todos os dias. (...) A descoberta do esquema colocava muitas reputações em risco. Os politicos que formam o verdadeiro núcelo de poder no Congresso tiveram de intervir. (...) As assinaturas necessárias para abrir a CPI do Orçamento tinham sido colhidas em menos de uma semana, ainda em novembro de 1991, quando Alves foi afastado da relatoria. A comissão só não tinha saído da gaveta em razão do bloqueio politico exercido por Ibsen e Benevides e pelos dois principais partidos na Câmara: o PMDB de Genebaldo Correia e o PFL de Ricardo Fiúza.”

A instalação da CPI do Orçamento mais tarde, em outubro de 1993, abriu enormemente a agenda de opções institucionais possíveis relativas ao desenho orçamentário, iniciando a critical juncture que terminou em setembro de 1995.

Em 2005-2006, a “escolha contrafactual” pode ser a ineficácia da estratégia do deputado Ricardo Barros em convencer a Mesa Diretora do Congresso Nacional em colocar seu projeto de resolução em votação no plenário. O próprio Barros (2007, p. 1214) conta sua estratégia: "Travei uma verdadeira batalha para que o projeto fosse apreciado no Congresso. Como principal arma, eu me vali da obstrução, que me era facultada, como a qualquer congressista, pelo artigo 28 do Regimento Comum, que exige o quórum mínimo de um sexto dos parlamentares de cada Casa durante o transcurso das sessões do Congresso. A obstrução teve início na votação do Orçamento 
2006 e a verdade é que sempre tive o apoio de todos, inclusive do presidente do Senado, Renan Calheiros, que nunca se furtou aos elogios ao projeto de Resolução, mas era dificílimo ver a matéria ser votada porque tais alterações contrariavam os mais diversos interesses. (...) Quando veio a Lei de Diretrizes Orçamentárias de 2007, novamente me coloquei em obstrução (...). Contudo, a matéria não ia à pauta, embora já tivesse recebido pareceres favoráveis na Câmara e no Senado. Na tentativa de avançar, o presidente do Senado, Renan Calheiros, determinou a um grupo de parlamentares que estudasse as mudanças necessárias para obter-se o consenso. A relatoria ficou a cargo do deputado José Carlos Aleluia, que desenvolveu um grande trabalho. Por esta e outras razões, a LDO 2007 não foi aprovada no prazo constitucional, impedindo o recesso de julho (...). A obstrução continuava e o presidente Renan Calheiros determinou ao senador Romero Jucá que tentasse o entendimento, pois outras sessões do Congresso não foram convocadas por falta deste consenso para votação da matéria. Em novembro de 2006, foi convocada uma sessão para votar créditos que permitiriam o aumento do poder Judiciário, TCU e Ministério Público. A pressão era enorme, mas mantivemos a obstrução. Nos dias subseqüentes, recebi mais de 3.500 e-mails dos servidores e sindicatos envolvidos reclamando da obstrução. Desta vez não cedi aos apelos sob o compromisso de que a resolução seria votada antes do PLO 2007, o que finalmente aconteceu em 28 de novembro de 2006".

É bastante plausível que o insucesso de Barros teria ocorrido também no fim de 2006 se não fosse a instalação da CPI das Ambulâncias/Sanguessugas em junho daquele ano, investigando corrupção descentralizada no processo orçamentário, envolvendo ao menos 72 parlamentares. O relatório final da CPI foi publicado em agosto de 2006. Isto colocou o tema "processo orçamentário" novamente na mídia e ajudou a impedir que o Executivo e demais parlamentares freassem as mudanças propostas na resolução de Ricardo Barros. Outro incentivo para que o Executivo e outros parlamentares não freassem a resolução de Barros é que várias das idéias ali contidas não feriam interesses tão amplamente. Ou seja, era um projeto de resolução razoavelmente "manso" se comparado a outras idéias em circulação na época, como veremos com mais detalhes nos capítulos quatro e cinco.

Além da necessidade em realizar análise contrafactual, Capoccia e Kelemen (2007, p. 347-348) identificam quatro problemas na literatura que utiliza o conceito de critical junctures. Trata-se de: i) má identificação da unidade de análise; ii) noção ruim de como lidar com aspectos temporais relacionados aos efeitos das critical junctures; 
iii) falta de atenção às assimetrias de poder dos atores dentro das critical junctures; iv) identificação das critical junctures apenas como momentos onde mudanças institucionais ocorrem, sem prestar atenção aos casos de "near miss" - ou seja, momentos nos quais mudanças quase ocorreram.

Meu trabalho lida diretamente com três desses problemas. O mais simples é a identificação da unidade de análise: claramente, aqui, são as regras orçamentárias. É um recorte substantivo, não temporal. Trato agora da falta de atenção à desiguadade de recursos com que atores políticos diferentes são dotados dentro das critical junctures. É algo herdado da literatura do neoinstitucionalismo econômico e que já encontrou críticas mais abrangentes entre estudiosos da escolha racional, como Moe (2005) e Levi (2009). O controle da agenda política, conforme Moe (2005) sugere, pode ser um bom método para analisar qual é a extensão dos poderes de cada ator ou grupo político para manter ou alterar arranjos institucionais vigentes. Como se vê, a coalizão liderada pelo Executivo controlou amplamente a agenda política durante a critical juncture que resultou na resolução 2/1995, enquanto em 2006, como já foi relatado acima, o entrepreneur Ricardo Barros obteve sucesso apenas depois da CPI das Ambulâncias/Sanguessugas no segundo semestre daquele ano.

A tabela 2.1 mostra detalhes sobre o controle da agenda política durante as duas critical junctures aqui analisadas. 
Tabela 2.1: Assimetrias de poder e controle das agendas políticas em critical junctures

\begin{tabular}{|c|c|c|}
\hline & 1994-1995 & 2005-2006 \\
\hline $\begin{array}{l}\text { Criação de grupo de } \\
\text { trabalho para realizar } \\
\text { reforma orçamentária }\end{array}$ & Sim & Sim \\
\hline $\begin{array}{l}\text { Composição do grupo } \\
\text { de trabalho }\end{array}$ & $\begin{array}{l}7 \text { deputados (4 } \\
\text { coalizão, } 3 \text { oposição) e } \\
7 \text { senadores }{ }^{46} \text { (4 } \\
\text { coalizão, } 3 \text { oposição). } \\
\text { Relator do GT é } \\
\text { senador da coalizão. }\end{array}$ & $\begin{array}{l}12 \text { deputados ( } 8 \text { coalizão, } 4 \\
\text { oposiçãa) e } 12 \text { senadores }{ }^{47} \text { (6 } \\
\text { coalizão, } 6 \text { oposição). Relator } \\
\text { do GT é deputado da oposição. }\end{array}$ \\
\hline $\begin{array}{l}\text { Institucionalização do } \\
\text { grupo de trabalho }\end{array}$ & $\begin{array}{l}\text { Baixa, reuniões } \\
\text { informais }\end{array}$ & Alta, reuniões formais com atas \\
\hline $\begin{array}{l}\text { Projeto de resolução } \\
\text { proposto formalmente } \\
\text { pelo grupo de trabalho }\end{array}$ & Sim, PRN 4/1995. & $\begin{array}{l}\text { Não. Ricardo Barros propôs } \\
\text { PRN } 2 / 2005 \text { sozinho. }\end{array}$ \\
\hline $\begin{array}{l}\text { Entrepreneur apoiando } \\
\text { o projeto de resolução }\end{array}$ & Não & Sim, Ricardo Barros \\
\hline Pedido de urgência & $\begin{array}{l}\text { Requerido por líderes } \\
\text { partidários }\end{array}$ & Não \\
\hline $\begin{array}{l}\text { Relator ao projeto } \\
\text { favorável ao Executivo }\end{array}$ & $\begin{array}{l}\text { Sim, Renan Calheiros } \\
\text { (coalizão) }\end{array}$ & $\begin{array}{l}\text { Não, José Carlos Aleluia } \\
\text { (oposição) }\end{array}$ \\
\hline $\begin{array}{l}\text { Processo de votação em } \\
\text { plenário }\end{array}$ & $\begin{array}{l}\text { Rápido, sem votação } \\
\text { nominal }\end{array}$ & $\begin{array}{l}\text { Intensamente disputado e } \\
\text { polêmico, mas sem votação } \\
\text { nominal }\end{array}$ \\
\hline
\end{tabular}

Antes de seguir a análise, cabe definir o que é um entrepreneur. Proponho que um ator seja definido como entrepreneur caso satisfaça duas condições. A primeira é tentar aproveitar-se de ao menos uma das três características institucionais que, segundo Sheingate (2007), estimulam entrepreneurs. A segunda é ligada a Kingdon (1995), para quem a tenacidade e entusiasmo por uma certa proposta ajudam a definir um entrepreneur.

As três características institucionais que podem ajudar entrepreneurs, de acordo com Sheingate (2007, p. 15), são: i) a heterogeneidade de regras, ii) a incerteza a

\footnotetext{
${ }^{46}$ Os deputados são: Adylson Motta (PPB, oposição), Gonzaga Mota (PMDB, coalizão), Humberto Souto (PFL, coalizão), Luiz Carlos Hauly (PSDB, coalizão), Paulo Bernardo (PT, oposição), Sérgio Guerra (PSB, oposição) e Yeda Crusius (PSDB, coalizão). Os senadores são: Beni Veras (PSDB, coalizão), Eduardo Suplicy (PT, oposição), Esperidião Amin (PPB, oposição), Gilberto Miranda (PFL, coalizão), João Rocha (PFL, coalizão), José Fogaça (PMDB, coalizão, relator do grupo de trabalho), e Roberto Freire (PPS, oposição).

${ }^{47}$ Os deputados são: Cláudio Cajado (PFL, oposição), Eduardo Valverde (PT, coalizão), Fernando Coruja (PPS, coalizão), Gilmar Machado (PT, coalizão), Iberê Ferreira (PTB, coalizão), Jorge Bittar (PT, coalizão), Milton Monti (PL, coalizão), Pauderley Avelino (PFL, oposição), Pedro Novais (PMDB, coalizão), Ricardo Barros (PP, oposição), Ronaldo Dimas (PSDB, oposição), Sérgio Miranda (PC do B, coalizão). Os senadores são: Aloizio Mercadante (PT, coalizão), Antônio Carlos Valadares (PSB, coalizão), Efraim Morais (PFL, oposição), Fernando Bezerra (PTB, coalizão), Geraldo Mesquita Jr. (PSOL, oposição), Héraclito Fortes (PFL, oposição), Leonel Pavan (PSDB, oposição), Maguito Vilela (PMDB, coalizão), Marcelo Crivella (PL, coalizão), Osmar Dias (PDT ,oposição), Romero Jucá (PMDB, coalizão), Sérgio Guerra (PSDB, oposição).
} 
respeito dos resultados das combinações de regras e iii) a ambiguidade inerente às regras. A heterogeneidade considera o fato de que diversas regras podem ser combinadas e recombinadas de maneira criativa por entrepreneurs, de modo a conseguir, com essas recombinações, um resultado que não seria conseguido de outro modo. Essas múltiplas conexões entre regras institucionais fazem com que seja muito difícil prever como a mudança em uma regra afetará outras partes do sistema politico. Essa incerteza a respeito dos resultados das combinações de regras pode abrir espaço para oportunidades especulativas do entrepreneur que dirá, por exemplo, que a combinação das regras X e Y levará ao resultado A, aproveitando-se da incerteza de outros atores sobre os resultados que virão da combinação das regras. À medida que as regras se tornam mais complexas, ao serem recombinadas, torna-se mais difícil diferenciar onde o limite de uma regra termina e outra começa. Em outras palavras, há uma ambiguidade intrínseca à interpretação das regras. Entrepreneurs podem se aproveitar da ambiguidade a respeito da interpretação e aplicação de regras institucionais para conseguir os resultados que desejam.

Neste trabalho, considero dois parlamentares como entrepreneurs de instituições orçamentárias: o deputado federal Ricardo Barros (PP) e o senador Antônio Carlos Magalhães (PFL). Barros e Magalhães foram ambos tenazes. Magalhães anunciou sua proposta de Orçamento Impositivo em junho de 2000, e não a esqueceu por seis anos, até ela ser barrada pela coalizão governista na Câmara dos Deputados. Barros trabalhou por no mínimo um ano e meio para mudar regras orçamentárias, primeiro sendo relator do grupo de trabalho criado em 2005 para reestruturar o processo orçamentário e depois propondo um projeto de resolução e trabalhando fortemente para aprová-lo em plenário.

Com relação às três características institucionais apontadas por Sheingate (2007), Ricardo Barros buscou aproveitar-se da heterogeneidade de regras que regulamentam as votações em plenário, conforme relatei acima, negociando com diversos parlamentares de modo a forçar a votação do que se tornou a Resolução 1/2006. Além disso, Barros aproveitou-se, em vários momentos, da incerteza (e indiferença) a respeito dos resultados das combinações de regras por parte de outros atores sobre os resultados que viriam com sua proposta de resolução. Quando os outros atores contestam muito fortemente sua proposta (por exemplo, ter um Relator da Receita indicado pela oposição, como veremos no quinto capítulo), Barros negocia com eles. 
Por sua vez, Magalhães, tentou aproveitar-se da incerteza dos outros atores a respeito dos efeitos do Orçamento Impositivo, utilizando diversos enquadramentos discursivos para convencê-los de que o Orçamento Autorizativo poderia ser pior para eles. No entanto, não foi bem-sucedido devido ao fato de que muitos outros atores, sobretudo parlamentares da coalizão, tinham fortes prefêrencias pelo status quo do Orçamento Autorizativo. Ou seja, a incerteza a ser explorada era mínima.

É necessário, também, identificar nas critical junctures as escolhas que atores podiam ter feito - e que alterariam resultados substantivos - mas não fizeram. São os "near misses" a que Capoccia e Kelemen (2007, p. 347-348) se referem. A tentativa de adoção do Orçamento Impositivo, algo relativamente forte na agenda de reformas orçamentárias, é um bom exemplo e será tratado no sexto capítulo.

Por fim, Capoccia e Kelemen (2007, p. 360-361) propõem dois critérios para analisar quão "crítica" é uma critical juncture. Trata-se do "pulo da probabilidade" (probability jump) e "relevância temporal" (temporal leverage). O pulo da probabilidade é calculado através de dois fatores. O primeiro é: quanto maior for a probabilidade de um resultado ao fim da critical juncture em relação a sua probabilidade logo antes da critical juncture, maior é o "pulo da probabilidade". O segundo é que o pulo da probabilidade será tanto maior quanto mais provável for o mesmo resultado definido pela critical juncture depois de ela haver terminado.

Em 1995, o resultado analisado é “regras orçamentárias pró-coalizão". A probabilidade deste resultado ao fim da critical juncture era altíssima - pois, como vimos acima, a coalizão controlou a agenda -, enquanto a probabilidade deste resultado logo antes da critical juncture era baixíssima, pois um grupo parlamentar corrupto, não ligado à coalizão e pouco preocupado com impactos macroeconômicos de seus atos, controlava o processo orçamentário. Logo, o "pulo da probabilidade" em relação a este quesito para a critical juncture de 1994-1995 é alto. Em 2006, o resultado analisado é "regras orçamentárias contra coalizão (proposta de Ricardo Barros)". A probabilidade deste resultado ao fim da critical juncture era baixo - afinal, a coalizão controlava o grupo de trabalho relatado por Barros, bem como o plenário - enquanto a probabilidade deste resultado logo antes da critical juncture era baixa, pois a coalizão controlou bem o processo orçamentário e a definição das regras entre 1995 e 2005. Logo, o "pulo da probabilidade" em relação a este quesito para a critical juncture de 2005-2006 é baixo.

$\mathrm{O}$ segundo quesito para verificar se o pulo da probabilidade de uma critical juncture é que este será tanto maior quanto mais provável for o mesmo resultado depois 
de a critical juncture haver terminado. Em relação à escolha feita em 1995, ela seria bastante provável depois já que foi praticamente "consensual" e o processo orçamentário funcionou a contento do Executivo nos anos seguintes (Figueiredo e Limongi 2008). No entanto, para a escolha feita em 2006, ela seria muito pouco provável logo depois da critical juncture, pois a Resolução 1/2006 não foi nada consensual: o grupo de trabalho relatado por Ricardo Barros não conseguiu elaborar proposta e a resolução teve votação muito disputada em plenário. Além, disso, diversos pontos da Resolução 1/2006 não têm sido obedecidos pelos parlamentares.

Finalmente, a "relevância temporal" diz respeito a quão duradouras são as escolhas feitas na critical juncture em questão. Se a de 2005-2006 ainda não pode ser avaliada, a de 1994-1995 foi razoavelmente relevante, pois muitas das escolhas permanecem ainda hoje, como veremos em capítulos dedicados às prerrogativas de emendamento e organização da Comissão Mista de Orçamento. Já que uma juncture será mais critical quanto maior for sua "relevância temporal" e "pulo da probabilidade", a de 1994-1995 foi mais "crítica" - em duas das três dimensões, pelo menos - do que a de 2005-2006 para as instituições orçamentárias.

Tabela 2.2: Criticalness dos períodos analisados

\begin{tabular}{|l|l|l|}
\hline $\begin{array}{l}\text { Pulo da probabilidade (I): resultado } \\
\text { da CJ era bem mais provável ao } \\
\text { ponto final da CJ do que era no } \\
\text { começo? }\end{array}$ & Sim & Nâ5-2006 \\
\hline $\begin{array}{l}\text { Pulo da probabilidade (II): resultado } \\
\text { da CJ seria provável após seu } \\
\text { término? }\end{array}$ & Sim, muito & Pouco \\
\hline Relevância temporal & Razoável & -- \\
\hline
\end{tabular}

Há outro fator para auxiliar na avaliação de quão crítico é um período, complementado o argumento de Cappocia e Kelemen (2007). Trata-se, eu proponho, de medir o deslocamento de preferências de atores políticos durante a critical juncture. Se um parlamentar da coalizão defende, por exemplo, que a Comissão Mista de Orçamento dê poucos poderes para o relator-geral - sendo que este é um cargo costumeiramente ocupado por alguém da coalizão - esta é uma idéia que revela "preferência deslocada". Quanto mais preferências deslocadas houver, mais critical terá sido a juncture. Podemos imaginar que as preferências deslocadas ocorram em relação aos três interesses de curto prazo já citados em outro capítulo (reeleição, pertencimento à 
coalizão/oposição, acesso a postos institucionais) e que entrepreneurs como o deputado Ricardo Barros apresentem muitas "preferências deslocadas", pois estão tentando negociar, estrategicamente, diversos pontos para fazer seu projeto passar. Elas serão analisadas nos capítulos quatro e cinco.

\section{(2) Narrativas analíticas e critical junctures}

Outro elemento fundamental para entender como decisões foram tomadas (ou não tomadas) durante critical junctures é uma narrativa analítica cuidadosa, algo que implica definir os jogos, as opções disponíveis e as escolhas dos atores (conforme Mahoney 2005) e o contexto estrutural no qual as escolhas estão inseridas (conforme Pedriana 2005). A principal função da narrativa analítica é ligar as duas critical junctures analisadas neste trabalho ${ }^{48}$.

Mahoney (2005) propõe uma operacionalização interessante de "narrativa analítica", focando como a perspectiva de escolha racional pode suprir certas lacunas da linha institucionalista histórica. O fato de processos de mudança institucional ocorrerem ao longo do tempo e serem influenciados por eventos e escolhas do passado está longe de significar que os processos são puramente "históricos" e, por isso, que a agency de atores políticos pouco importa. Identificar formalmente as opções dos atores ${ }^{49}$ nas critical junctures é essencial para entender os processos de estabilidade e mudança institucional. Enquanto os institucionalistas históricos tratam critical junctures como momentos de grande contingência, nos quais as decisões tomadas pelos atores são essencialmente imprevisíveis, os analistas de escolha racional oferecem um arsenal teórico para modelar estas decisões como instrumentais, realizadas lucidamente considerando o contexto estrutural presente (Mahoney 2005, p. 313).

Há dois conjuntos de escolhas institucionais plausíveis referentes a prerrogativas de emendamento a estudar nas critical junctures de 1994-1995 e 2005-2006: emendas parlamentares ilimitadas ou emendas parlamentares limitadas. Com relação à organização dos trabalhos da Comissão Mista de Orçamento do Congresso Nacional, há também dois conjuntos de escolhas institucionais plausíveis: organização

\footnotetext{
48 De acordo com Pedriana (2005, p. 351), uma narrativa organiza eventos cronologicamente em um "todo" analítico que faz sentido. Apesar de críticas ao método narrativo como simplificador demais, ignorando contingências, erros e fatos que desviam da história a ser contada, a perda de complexidade é compensada pelo ganho heurístico. (Ver tedxmidatlantic.com/live/\#TylerCowen)

49 Além de explicar como nelas se forma a agenda de opções políticas, algo que farei nos capítulos a seguir.
} 
descentralizada ou organização centralizada. $\mathrm{O}$ emendamento e a organização do processo orçamentário são dois dos eixos básicos do trabalho parlamentar no orçamento (Wehner 2006).

Interessaria fortemente à coalizão governista dentro do Legislativo estabelecer certos limites às emendas, mesmo considerando que a coalizão controla a execução orçamentária e pode simplesmente não executar as emendas. Ainda asism, o Executivo pode ganhar se não tiver que negociar emendas, e a coalizão representa os interesses do Executivo. Portanto, podemos esperar que os parlamentares da coalizão sejam favoráveis a propostas no sentido de limitar as prerrogativas de emendar o orçamento. Este interesse deve ser forte sobretudo em relação às emendas coletivas, pois se trata de um espaço institucional que pode ser aproveitado por parlamentares da oposição para compensar a baixa execução de emendas individuais.

Não interessaria aos parlamentares da oposição estabelecer limites às emendas, pois perderiam espaço para barganhar a liberação de ao menos parte de suas emendas com o Executivo. Além disso, se as emendas coletivas fossem limitadas, a oposição perderia outra venue para negociar seus interesses orçamentários. Caso houvesse Orçamento Impositivo, é provável que a posição dos membros oposicionistas em relação a limites para emendas fosse mais flexível. Não é este o caso, no entanto, e podemos esperar que os parlamentares da oposição se oponham, fortemente, a propostas no sentido de limitar as prerrogativas de emendar o orçamento.

O cenário "emendas orçamentárias ilimitadas" configuraria: a) nenhum limite de valor global para emendas orçamentárias; b) nenhum limite ao número de emendas por parlamentar; c) diversos atores com a prerrogativa de propor emendas coletivas; d) natureza bastante abrangente, pouco definida, para as emendas coletivas.

O segundo conjunto de escolhas institucionais trata da organização da Comissão Mista de Orçamento. Interessaria fortemente à coalizão governista dentro do Legislativo estabelecer uma comissão centralizada, pois o Regimento Interno do Congresso Nacional dispõe que as comissões são compostas de acordo com critérios de proporcionalidade partidária - e o Executivo tradicionalmente sela acordos suficientes para indicar o Relator-Geral desta comissão. Portanto, quanto mais poderoso o RelatorGeral, melhor para a coalizão. A oposição, por sua vez, é contra um Relator-Geral poderoso e a favor de uma organização descentralizada. Afinal, já que a CMO é tradicionalmente controlada pela coalizão, parlamentares oposicionistas terão maior chance de interferir no orçamento se outras comissões tiverem mais poder. Supondo que 
a CMO seja poderosa, a oposição terá interesse em fortalecer os relatores setoriais que auxiliam o Relator-Geral, pois ao menos alguns dos relatores setoriais não deverão ser indicados pela coalizão ${ }^{50}$.

O cenário "Comissão Centralizada" configuraria: i) relator-geral com poder para propor emendas; ii) relator-geral com poder para estimar receita; ii) CMO como responsável pelo orçamento, mas com relatorias setoriais fracas (subordinadas ao RG). O cenário "Comissão Descentralizada" seria: a) relator- geral sem poder para propor emendas; b) relator-geral sem poder para estimar receita; c) CMO apenas como “organizadora final" e outras comissões como responsáveis pelo orçamento ou d) CMO como responsável pelo orçamento, mas com subcomissões/relatorias setoriais poderosas em relação ao $\mathrm{RG}$.

É imprescindível frisar o impacto que a instituição do Orçamento Autorizativo tem para moldar as preferências dos parlamentares da coalizão. Eles têm preferências fortíssimas contra uma comissão orçamentária descentralizada e preferências mais fracas contra o emendamento ilimitado, pois a coalizão controla a execução orçamentária - já que o orçamento é autorizativo e não impositivo. O controle sobre a execução compensaria desvantagens do emendamento ilimitado, mas não haveria nada para balancear desvantagens de uma comissão descentralizada, com muitos relatores (dotados de fortes prerrogativas vis-à-vis o Relator-Geral) pertencentes à oposição.

Em outras palavras, o emendamento (limitado ou ilimitado) não afeta as probabilidades das escolhas institucionais. Embora parlamentares de coalizão e oposição tenham preferências divergentes a respeito do tipo de emendamento, o que importa mesmo é a organização da comissão orçamentária, já que a execuçao orçamentária sempre será da coalizao. Portanto, a natureza do emendamento é algo que está mais “em jogo”, mais “a negociar”, do que a organização do processo.

De acordo com Mahoney (2005, p. 317), a teoria de escolha racional considera quatro elementos como componentes da escolha de um ator: as opções comportamentais disponíveis para este ator; os resultados específicos que podem advir de certa escolha; a utilidade associada a cada uma dessas escolhas; a probabilidade de que certo resultado ocorrerá a partir de certa escolha e, por fim, a utilidade esperada se certa escolha for

\footnotetext{
${ }^{50}$ Novamente, o critério para nomear os relatores setoriais é o da proporcionalidade partidária.
} 
realizada. A seguir, apresento tabelas que modelam esses elementos ${ }^{51}$ tanto para os parlamentares da coalizão quanto os da oposição nas critical junctures analisadas.

Tabela 2.3: Escolhas institucionais para a Coalizão nas critical junctures de 1995 e 2006

\begin{tabular}{|l|l|l|l|}
\hline Resultados possíveis & Utilidade & Probabilidade & Utilidade esperada \\
\hline $\begin{array}{l}\text { Emendamento Limitado + } \\
\text { CMO Centralizada }\end{array}$ & $\begin{array}{l}\text { Alta: 1995 } \\
\text { Altíssima: 2006 }\end{array}$ & Alta: 1995 e 2006 & Alta: 1995 e 2006 \\
\hline $\begin{array}{l}\text { Emendamento Ilimitado + } \\
\text { CMO Centralizada }\end{array}$ & $\begin{array}{l}\text { Alta: 1995 } \\
\text { Altíssima: 2006 }\end{array}$ & Alta: 1995 e 2006 & Alta: 1995 e 2006 \\
\hline $\begin{array}{l}\text { Emendamento Limitado + } \\
\text { CMO Descentralizada }\end{array}$ & Baixa: 1995 e 2006 & Baixa: 1995 e 2006 & Baixa: 1995 e 2006 \\
\hline $\begin{array}{l}\text { Emendamento Ilimitado + } \\
\text { CMO Descentralizada }\end{array}$ & $\begin{array}{l}\text { Baixíssima: 1995 e } \\
\text { 2006 }\end{array}$ & Baixa: 1995 e 2006 & Baixa: 1995 e 2006 \\
\hline
\end{tabular}

Tabela 2.4: Escolhas institucionais para a Oposição nas critical junctures de 1995 e 2006

\begin{tabular}{|l|l|l|l|}
\hline Resultados possíveis & Utilidade & Probabilidade & Utilidade esperada \\
\hline $\begin{array}{l}\text { Emendamento Limitado + } \\
\text { CMO Centralizada }\end{array}$ & $\begin{array}{l}\text { Média: 1995 } \\
\text { Baixíssima: } 2006\end{array}$ & Alta: 1995 e 2006 & Média: 1995 e 2006 \\
\hline $\begin{array}{l}\text { Emendamento Ilimitado + } \\
\text { CMO Centralizada }\end{array}$ & $\begin{array}{l}\text { Média: 1995 } \\
\text { Baixa: 2006 }\end{array}$ & Alta: 1995 e 2006 & Média: 1995 e 2006 \\
\hline $\begin{array}{l}\text { Emendamento Limitado + } \\
\text { CMO Descentralizada }\end{array}$ & Alta: 1995 e 2006 & Baixa: 1995 e 2006 & Média: 19952006 \\
\hline $\begin{array}{l}\text { Emendamento Ilimitado + } \\
\text { CMO Descentralizada }\end{array}$ & $\begin{array}{l}\text { Altíssima: } 1995 \text { e } \\
\text { 2006 }\end{array}$ & Baixa: 1995 e 2006 & Média: 1995 e 2006 \\
\hline
\end{tabular}

A utilidade de uma comissão centralizada é mais alta para parlamentares da coalizão ${ }^{52}$ em 2006 do que em 1995 porque, ao fim da primeira critical juncture, não se sabia como esta instituição funcionaria. Mas as preferências orçamentárias da coalizão entre 1995 e 2006 foram largamente garantidas pela facilidade em controlar a CMO centralizada (Figueiredo e Limongi 2008). É um bom exemplo para corroborar a afirmaçao de Pedriana (2005, p. 360), para quem a análise do funcionamento de uma instituição que dá retornos crescentes a certos atores, complementa a perspectiva da escolha racional, pois os custos e benefícios de certa escolha institucional são recalculados de modo a tornar uma escolha mais atraente no tempo $X+1$ do que no tempo X.

As probabilidades assinaladas nas tabelas acima são diretamente relacionadas ao controle da agenda política em cada critical juncture. A probabilidade de escolher a opção institucional "CMO descentralizada" é baixa nas duas critical junctures, pois a coalizão controla a agenda política nos dois períodos e prefere a CMO centralizada. No

${ }^{51}$ À exceção do elemento das "opções comportamentais", pois isto engloba as idéias e alternativas disponíveis em cada critical juncture e serão analisadas em capítulos específicos.

${ }^{52}$ Portanto, mais baixa para parlamentares da oposição em 2006 do que em 1995. 
entanto, a probabilidade de uma CMO descentralizada deveria ser ainda mais baixa em 2006 (pois a coalizão tem mais motivos para gostar do desenho centralizado adotado), pois nesta critical juncture há um entrepreneur da oposição, deputado Ricardo Barros, pressionando para descentralizar aspectos da comissão. Mas qualquer entrepreneur é, quase por definição, mais fraco do que uma coalizão bem-organizada e com preferências tão contrárias à descentralização - daí a atribuição de "baixa probabilidade" à CMO descentralizada em 2006.

\section{(3) Resultados institucionais das critical junctures}

A tabela 2.5 resume as escolhas feitas em relação ao emendamento orçamentário nas critical junctures de 1995 e 2006, além do status quo inicial de 1991/1993.

Tabela 2.5: Escolhas institucionais sobre emendamento orçamentário, 1991-2006

\begin{tabular}{|l|l|l|l|}
\hline & $\mathbf{1 9 9 1 / 1 9 9 3}$ & $\mathbf{1 9 9 5}$ & $\mathbf{2 0 0 6}$ \\
\hline $\begin{array}{l}\text { Número de emendas } \\
\text { individuais }\end{array}$ & Limitado a 50 & Limitado a 20 & Limitado a 25 \\
\hline $\begin{array}{l}\text { Natureza de emendas } \\
\text { individuais }\end{array}$ & $\begin{array}{l}\text { Limitado } \\
\text { constitucionalmente }\end{array}$ & $\begin{array}{l}\text { Limitado } \\
\text { constitucionalmente }\end{array}$ & $\begin{array}{l}\text { Limitado } \\
\text { constitucionalme } \\
\text { nte + outros } \\
\text { limites }\end{array}$ \\
\hline $\begin{array}{l}\text { Valor global de emendas } \\
\text { individuais }\end{array}$ & Ilimitado & Ilimitado & $\begin{array}{l}\text { Limitado } \\
\text { informalmente }\end{array}$ \\
\hline $\begin{array}{l}\text { Atores que podem propor } \\
\text { emendas coletivas }\end{array}$ & Nenhum & Limitado & Limitado \\
\hline $\begin{array}{l}\text { Número de emendas } \\
\text { coletivas }\end{array}$ & Não havia & Limitado & Limitado \\
\hline $\begin{array}{l}\text { Natureza de emendas } \\
\text { coletivas }\end{array}$ & Não havia & Um pouco limitada & $\begin{array}{l}\text { Bastante } \\
\text { limitada }\end{array}$ \\
\hline Valor de emendas coletivas & Não havia & Ilimitado & Ilimitado \\
\hline
\end{tabular}

De prerrogativas praticamente ilimitadas em 1991 e 1993, passou-se a um resultado misto em 1995 e fortemente limitado com a Resolução 1/2006. O mistério relevante a explicar é: se em 1995 a coalizão controlou a agenda política da critical juncture, e era de seu interesse limitar o máximo possível as prerrogativas de emendamento, por que os valores globais das emendas individuais e coletivas permaneceram ilimitadas? E por que a natureza das emendas coletivas não foi limitada? Trata-se de duas conseqüencias inesperadas de escolhas institucionais, algo bastante comum em processos desse tipo (Pierson 2000, Miller 2000). 
Apenas dois anos após a Resolução 2/1995, um acordo informal entre o relatorgeral, membros do Executivo e parlamentares tanto da coalizão quanto da oposição para limitar o valor global das emendas individuais foi implementado. Essa situação se repetiu nos anos seguintes e, em 2001, a necessidade de um acordo informal para estabelecer esse limite foi consagrada formalmente em resolução. Ou seja, a coalizão não vislumbrou que essa medida seria necessária em 1995, mas corrigiu-a, ainda que informalmente, logo em seguida. $\mathrm{O}$ valor global das emendas coletivas ainda não foi limitado para além das condições estabelecidas na Constituição Federal $^{53}$ provavelmente por não interessar a parlamentares da coalizão nem da oposição. Parlamentares da coalizão poderiam defender esse limite de valor pensando em dificuldades do Executivo em controlar as escolhas macroeconômicas, atrapalhado pela ânsia dos parlamentares em emendar. Isso está longe de ocorrer, considerando o valor ainda ínfimo que as emendas (coletivas e individuais) representam para o total do orçamento.

A conseqüencia inesperada em não limitar a natureza das emendas coletivas foi o uso destas como "emendas individuais partilhadas", ou "rachadinhas". Trata-se de emendas individuais travestidas de coletivas, permitindo que parlamentares agindo em conluio consigam tentar atender suas bases eleitorais com uma só emenda orçamentária formal. Este uso das emendas coletivas está mais relacionado a oportunidades corruptas, como mostrou a CPI das Ambulâncias/Sanguessugas, do que ao controle da coalizão sobre o orçamento. Portanto, não poderíamos esperar que a coalizão que controlou a critical juncture de 1994-1995 pudesse antecipar a situação de modo a evitá-la.

A tabela 2.6 mostra as escolhas sobre organização orçamentária nas critical junctures de 1994-1995 e 2005-2006, além do status quo inicial de 1991 e 1993.

\footnotetext{
${ }^{53}$ Nenhuma emenda orçamentária pode realocar verbas destinadas às despesas fixas do governo federal. São os gastos com pessoal (salários de funcionários públicos, por exemplo), gastos com dívidas e gastos com transferências constitucionalmente determinadas para estados e municípios.
} 
Tabela 2.6: Escolhas institucionais sobre organização orçamentária, 1991-2006

\begin{tabular}{|l|l|l|l|}
\hline & $\mathbf{1 9 9 1 / 1 9 9 3}$ & $\mathbf{1 9 9 5}$ & $\mathbf{2 0 0 6}$ \\
\hline $\begin{array}{l}\text { Relator-Geral com poder } \\
\text { para propor emendas }\end{array}$ & Sim, ilimitado & Sim, limitado & $\begin{array}{l}\text { Sim, extremamente } \\
\text { limitado }\end{array}$ \\
\hline $\begin{array}{l}\text { Relator-Geral com poder } \\
\text { para estimar receita }\end{array}$ & Sim & Sim & Não \\
\hline $\begin{array}{l}\text { CMO como responsável } \\
\text { pelo processo } \\
\text { orçamentário }\end{array}$ & Sim & Sim & Sim \\
\hline $\begin{array}{l}\text { CMO com relatores } \\
\text { setoriais poderosos em } \\
\text { relação ao Relator-Geral }\end{array}$ & Não & Não & Sim, em parte \\
\hline
\end{tabular}

Podemos notar que a critical juncture de 2005-2006, na qual o entrepreneur de oposição Ricardo Barros obteve sucesso em aprovar diversas mudanças nas regras orçamentárias, reverteu parte significativa das medidas centralizadores tomadas pela coalizão durante a critical juncture de 1994-1995. Elas serão analisadas detalhadamente no quinto capítulo.

Esta seção mostrou, portanto, como os dois grupos políticos - coalizão e oposição - formam suas preferências sobre instituições orçamentárias e como o controle da agenda legislativa por esses grupos nas critical junctures define as instituições orçamentárias que temos hoje no Brasil.

\section{(4) Contexto estrutural da narrativa analítica}

Se já observamos como a passagem do tempo pode influenciar a utilidade de certa escolha institucional para um grupo de atores políticos, cabe agora tratar de outro fator que exerce força parecida: o contexto estrutural. Pedriana (2005, p. 356) afirma que contextos estruturais podem alterar o modo como atores constroem suas escolhas e ranqueiam alternativas disponíveis. Vimos acima que a preferência de parlamentares da coalizão pelo conjunto institucional "Emendamento Limitado + CMO Centralizada" é mais forte em 2006 do que em 1995, pois neste período essas instituições funcionaram a contento. Ora, o contexto político - a natureza das relações Executivo/Legislativo e parlamentares/líderes partidárias - age enormemente no sentido de influenciar a preferência por estas instituições orçamentárias. Afinal, caso o desenho institucional fosse o mesmo mas as relações entre parlamentares e Executivo se pautassem muito 
mais por outros tipos de trocas e incentivos ${ }^{54}$, a preferência de parlamentares da coalizão poderia bem ser por outro desenho institucional.

Neste trabalho, o contexto que influencia as escolhas dos atores sobre instituições orçamentárias é composto por três tipos de relações: i) relações entre Executivo e Legislativo - ou seja, como e por quem a coalizão governista é composta; ii) relações entre parlamentares e líderes partidários; iii) a dinâmica de execução de emendas orçamentárias pelo Executivo.

A seguir, atenção será dada aos dois primeiros pontos, já que o relativo à dinâmica da execução orçamentária, que tem intensa relação com a formação dos interesses dos parlamentares da coalizão e oposição, já foi tratado no capítulo anterior.

\section{1) Relações Executivo-Legislativo no Brasil}

Pensemos no primeiro ano de um novo governo. Passada a eleição, o presidente e seu partido começam a angariar apoio de outras legendas, concedendo postos ministeriais, secretarias e cargos de comando a membros dos partidos aliados. Quando se iniciam os trabalhos legislativos propriamente ditos, define-se a composição da Mesa Diretora e das comissões permanentes por critérios de proporcionalidade partidária. Quanto maior a bancada de um partido, a mais cargos importantes ele terá direito no parlamento.

O apoio partidário na formação e manutenção de governos é uma das funções primordiais dos partidos políticos. Ainda que o presidente brasileiro tenha amplos poderes legislativos (prerrogativa de iniciar legislação em áreas temáticas específicas e emitir medidas provisórias, por exemplo), isto não quer dizer que pode governar contra a totalidade dos partidos representados no Congresso. É condição sine qua non para o funcionamento democrático que o presidente conte com alguma parcela de apoio partidário. Amorim Neto (2000) analisa se os partidos que compõem governos de coalizão recebem recompensas ministeriais proporcionais ao seu peso no Legislativo. Sua análise indica que uma distribuição eqüitativa dos postos ministeriais entre os partidos ajuda a fortalecer o apoio ao presidente.

Como o presidente maneja este apoio? Através do controle do processo legislativo, alcançado através da Mesa Diretora, o Colégio de Líderes e as comissões.

\footnotetext{
${ }^{54}$ Concessões substantivas nos projetos de lei, como as estudadas por Barrett $(2005,2007)$ no caso norteamericano; trocas corruptas; controle de instâncias estatais de modo descentralizado, como ocorre na cidade de São Paulo (Caetano 2005, p. 121).
} 
As Mesas Diretoras são os órgãos que administram as Casas Legislativas e dirigem grande parte dos trabalhos parlamentares. Os cargos da Mesa (presidente, Vicepresidentes e Secretários) são distribuídos pelo critério da proporcionalidade partidária. A presidência é um cargo de suma importância, pois é ela quem comanda os trabalhos legislativos, definindo a Ordem do Dia. Estabelece quais projetos serão apreciados e esclarece questões procedimentais importantes para a condução do processo deliberativo - com freqüência, de modo a favorecer os interesses do Executivo. A eleição da Mesa Diretora ocorre a cada dois anos. Os regimentos internos definem uma série de regras para a eleição dos membros da Mesa, porém, na prática, sabe-se que a escolha obedece a critérios políticos ${ }^{55}$.

Outra instância institucional importante para o funcionamento da coalizão é o Colégio de Líderes, formado pelos líderes das bancadas partidárias. A eles cabe encaminhar as votações nas comissões e no plenário e indicar os membros que irão compor as comissões, dirimir dúvidas, divergências e estabelecer acordos no andamento das matérias. Em alguns casos, há a expectativa de que as decisões se dêem por consenso ${ }^{56}$.

Os líderes são eleitos por suas respectivas bancadas partidárias e a presidência da República pode indicar um deputado para exercer a liderança do governo. O Colégio de Líderes é composto pelos líderes da maioria, da minoria, dos partidos, dos blocos parlamentares e do governo, e colabora com a Mesa Diretora na definição das prioridades legislativas. Constitui um dos mais importantes órgãos de discussão e de negociação política no que diz respeito à inclusão das matérias que irão à votação em plenário.

Podemos avaliar a participação dos parlamentares na tomada de decisão legislativa através da análise das propostas deliberadas. A taxa de aprovação dos projetos apresentados pelo Executivo é bastante expressiva, assemelhando-se às taxas de países parlamentaristas. O direito de exclusividade na apresentação de proposições em certas áreas e a possibilidade de emitir medidas provisórias, além da composição da coalizão delineada acima, dota o Executivo de expressiva capacidade de controle da agenda legislativa. Esse controle se reflete na produção legislativa do país: das 3.369

\footnotetext{
55 Durante o governo Sarney, presidiram a Câmara dos Deputados os deputados Ulysses Guimarães e Paes de Andrade, ambos do PMDB. Sob Fernando Collor e Itamar Franco, Ibsen Pinheiro (PMDB) e Inocêncio Oliveira (PFL) foram os presidentes. No primeiro governo FHC, os deputados Luís Eduardo Magalhães (PFL) e Michel Temer (PMDB), reconduzido ao cargo para os primeiros dois anos do segundo mandato e sucedido pelo tucano Aécio Neves, ocuparam o cargo mais alto da Câmara.

${ }^{56}$ Se este não for atingido, os líderes votam conforme o tamanho de suas bases. É o "voto ponderado".
} 
leis aprovadas entre 1989 e 2004, 2.711 foram apresentadas pelo Executivo e apenas 532 pelo Legislativo ${ }^{57}$.

Como leis são aprovadas no Brasil? Consideremos o caminho legislativo de um projeto de lei sobre educação, por exemplo. O governo apresenta o projeto e o encaminha para a Mesa Diretora. Esta definirá quais serão as comissões permanentes encarregadas de apreciar o projeto. Neste caso específico, uma delas seria a Comissão de Educação. Nesta instância, caberá ao presidente da comissão indicar o parlamentar que será o relator da matéria.

O relator é figura-chave no processo deliberativo, pois é com base no seu parecer que a matéria será colocada a voto. O parecer pode sugerir que o projeto seja aprovado na íntegra; pode apresentar emendas, isto é, alterar a proposta original; ou pode apresentar um substitutivo que é, muitas vezes, um novo projeto. Um presidente de comissão pouco simpático à proposta do governo poderá, por exemplo, indicar um parlamentar também pouco favorável à proposta para relatar a matéria. As resistências ao projeto começariam a se manifestar antes mesmo da matéria ser votada, seja na comissão ou no plenário.

Digamos que o projeto tenha sido relatado por alguém favorável à matéria proposta pelo governo. Não foram apresentadas grandes modificações ao texto original. O parecer é votado na comissão. Se aprovado, vai a plenário. Se o plenário for o da Câmara dos Deputados, o projeto será remetido para apreciação do Senado.Caso o Senado rejeite o projeto, ele será arquivado. Se alterado, voltará à Câmara para que as alterações feitas sejam analisadas. Se aprovado tal qual enviado pelo Senado, será encaminhado para sanção presidencial. Se a Câmara não concorda com as alterações feitas pelos senadores, permanece o seu texto, que será encaminhando para sanção.

Uma vez encaminhado à sanção, o projeto se torna lei caso o Executivo concorde com o texto aprovado pelo Legislativo. Se não, o presidente poderá vetá-lo totalmente ou parcialmente, isto é, promulgando apenas partes do projeto de lei. Ao Legislativo caberá dar a última palavra quanto a eventuais vetos presidenciais. Poderá manter o veto ou derrubá-lo, de acordo com a manifestação da maioria do plenário.

Pode ocorrer, no entanto, que o projeto tenha que ser apreciado por uma comissão um tanto hostil à proposta do governo. Para evitar um possível bloqueio por parte dos membros desta comissão, o Executivo pode contar com o apoio dos líderes

\footnotetext{
${ }^{57}$ As demais foram apresentadas pelo Judiciário.
} 
partidários que formam a base aliada do governo. Para isto, utilizam um mecanismo institucional: a solicitação de urgência que deve ser feita pelos membros do Legislativo. Esta solicitação está prevista no Regimento Interno da Câmara dos Deputados, que define as regras do jogo legislativo.

\section{2) Parlamentares e líderes partidários}

Relações intrapartidárias - isto é, entre parlamentares e os líderes de seus partidos - são também fundamentais para entender o contexto político no qual se inserem as escolhas institucionais relativas ao processo orçamentário. De acordo com Heller e Mershon (2009, p. 35), partidos podem assegurar a união de seus parlamentares através de três mecanismos: o controle negativo da agenda, a coesão e a disciplina partidária.

O controle negativo da agenda é a habilidade dos líderes partidários em impeder que projetos que dividirão os parlamentares não cheguem a plenário. No Brasil, assim como em outros países, isto é às vezes impossível, o que reforça a importânncia dos outros mecanismos. A coesão partidária trata da idéia de que membros do mesmo partido tem preferências comuns e que o principal propósito em formar o partido tenha sido organizar politicamente indivíduos que pensam do mesmo modo. Ainda que isso possa ser verdade, nem todos pensarão igual em relação a todos os temas. Quando a coesão falha, a união do partido pode ser obtida através da disciplina, ou seja, a imposição de custos para parlamentares que desobedecem a orientação de voto do seu líder partidário. É este último mecanismo que mais interessa para este trabalho, pois um dos custos plausíveis para o parlamentar brasileiro que não obedece seu líder é ver suas demandas orçamentárias pouco atendidas.

Até meados da década de 1990, a ciência política descrevia os partidos brasileiros como indisciplinados e disfuncionais para a consolidação da democracia e a governabilidade. As motivações para o comportamento indisciplinado estariam no sistema de governo presidencialista e no sistema eleitoral, proporcional de lista nãoordenada.

$\mathrm{O}$ argumento era que membros dos partidos governistas nos sistemas presidencialistas se sentem mais livres para votar contra o Executivo no plenário, porque a imposição de derrotas ao governo não os obriga a renunciar. Além disso, mandatos fixos e independentes não põem em risco a sobrevivência do próprio parlamento. Situação contrária à vivenciada nos parlamentarismos. Mas Figueiredo e 
Limongi (1995) afirmam que a disciplina partidária existente é suficiente para tornar o plenário previsível, pois as indicações de votação das lideranças tendem a serem apoiadas pelas respectivas bancadas. Como esses pesquisadores demonstraram, os mecanismos de ameaças e sanções que incentivam parlamentares a obedecerem seus líderes - entre os quais podemos incluir a barganha em torno da execução de emendas orçamentárias -, têm funcionado.

Vale relembrar, por fim, os dois grandes argumentos tratados neste capítulo. O primeiro é relacionadoà distribuição do poder político nas critical junctures durante as quais escolhas sobre instituições orçamentárias foram seriamente consideradas no Brasil. Em outras palavras, analisei quais grupos controlaram a agenda legislativa nestas critical junctures para entender quais resultados institucionais foram obtidos em vez de outros. O segundo argumento trata da definição das preferências dos atores que podem controlar a agenda das CJs, utilizando o modelo da "narrativa analítica". Os demais capítulos da tese estão extremamente ligados às critical junctures consideradas aqui. $\mathrm{O}$ capítulo a seguir mostra os antecedentes institucionais às duas CJs decididos pela Assembléia Nacional Constituinte de 1987-1998. O quarto capítulo trata de como aspectos relativos ao emendamento orçamentário mudaram ou permaneceram os mesmos durante as duas critical junctures, baseando-se nas preferências parlamentares analisadas na narrativa analítica exposta neste capítulo. O quinto capítulo faz o mesmo em relação à organização da Comissão Mista de Orçamento e, por fim, o sexto capítulo trata de como o entrepreneur Antônio Carlos Magalhães enfrentou o contexto estrutural de sua época para tentar, sem sucesso, implementar o Orçamento Impositivo no Brasil. 


\section{Capítulo 3}

\section{A definição de instituições orçamentárias pelos constituintes de 1987-1988}

A principal pergunta a ser respondida neste capítulo é: por que a Assembléia Nacional Constituinte de 1987-1988 decidiu por um processo orçamentário que representou continuísmo do período militar e, ao mesmo tempo, fortaleceu as prerrogativas do Legislativo na área de finanças públicas? O paradoxo está no fato de que a Constituinte foi controlada por atores contrários ao regime militar, o que torna estranha a continuidade de algumas instituições tão associadas à ditadura. Argumento que o fato de as instituições orçamentárias terem baixíssima saliência midiática durante o período de 1987-1988 permitiu que parlamentares conservadores, como José Luiz Maia e João Alves, definissem parte do desenho institucional orçamentário, aproveitando-se da indiferença de boa parte dos atores políticos.

O capítulo está dividido em cinco partes. A primeira introduz algumas noções básicas sobre o processo constituinte e a segunda seção apresenta um índice de saliência externa que permite contextualizar a importância da definição do processo orçamentário em relação a outros assuntos políticos da época. A seção 2 mostra como a saliência externa influenciou a escolha dos relatores das subcomissões e fornece alguns dados e expectativas sobre o relator da Subcomissão de Orçamento e Fiscalização Financeira, José Luiz Maia (PDS). A quarta seção é dedicada aos interesses legislativos mais influentes da Constituinte e como eles afetaram as definições sobre emendas orçamentárias e a Comissão Mista de Orçamento. Por fỉm, a seção 5 detalha, passo a passo, as decisões sobre processo orçamentário tomadas nas etapas mais relevantes da Constituinte.

Antes de iniciar a discussão sobre a Constituinte, vale um breve histórico do processo orçamentário brasileiro antes de 1987. Durante o período democrático de 1946-1964, os parlamentares brasileiros podiam propor e aprovar emendas orçamentárias sem limite constitucional, restringidas apenas pelo fato de o orçamento ser autorizativo e não impositivo - ou seja, o presidente podia optar por não realizar os gastos previstos na lei orçamentária ${ }^{58}$. Além disso, a tramitação do orçamento ocorria

\footnotetext{
${ }^{58}$ Santos (2007, p. 96) observa também que "não era permitido ao presidente vetar parcialmente a lei orçamentária. Pelo fato de que, freqüentemente, o projeto só era aprovado na iminência de se esgotar o prazo para o início do ano fiscal, restava ao Executivo caso discordasse veementemente da proposição
} 
em ambas as casas legislativas, sendo examinado e emendado tanto pela comissão permanente respectiva na Câmara dos Deputados e Senado Federal quanto pelo plenário das duas casas.

Segundo Baaklini (1993, p. 253-254), naquela época os “deputados e senadores tinham conhecimento prévio de que suas emendas ao orçamento não seriam aprovadas (quase todas as emendas diziam respeito a projetos que visavam dar aos políticos maior visibilidade junto a seu eleitorado), mas mesmo assim eles as submetiam e lutavam por elas, de maneira que seus eleitorados viessem a saber”. Emendas não executadas não resultam em déficit nem estimulam a inflação, mas o famoso diagnóstico de Roberto Campos sobre o processo orçamentário do período - "O Congresso havia se transformado em 'engenho de inflação' ao multiplicar o orçamento de dispêndio, e em 'fator de distorção' de investimentos pela sua hipersensibilidade a pressões regionais capazes de destruir a coerência e o equilíbrio de planos e programas" (Campos, 1975, p. 36) - vingou e sustentou, intelectualmente, reformas ao processo no período subseqüente.

A Constituição militar de 1967 retirou dos parlamentares a prerrogativa de emendar o orçamento enviado pelo Executivo. Dois anos depois, criou-se a Comissão Mista de Orçamento, limitando a tramitação legislativa do orçamento a apenas esta comissão e um plenário, o do Congresso Nacional. A reforma orçamentária em 1967 coube a um "tecnocrata politicamente imaturo", como Roberto Campos (1994, p. 786) se auto-definiu, com objetivo duplo: "Em primeiro lugar, evitar que o clientelismo legislativo se transformasse em pressão inflacionária, pelo inchaço de despesas. $\mathrm{O}$ outro objetivo era permitir uma visão global do dispêndio público, pois que o orçamento deveria incluir também a previsão de despesas e receitas de todos os poderes, órgãos e fundos, tanto da administração direta quanto da indireta, assim como o produto das operações de crédito" (Campos, 1994, p. 786).

Esta lógica orçamentária vigorou até a Constituição de 1988. Os parlamentares constituintes reunidos após a ditadura para restabelecer direitos individuais e coletivos, e também redesenhar as instituições políticas brasileiras, optaram por devolver ao Legislativo a atribuição de emendar partes do orçamento, com certos limites. Decidiram também manter a Comissão Mista de Orçamento como lócus para a participação de

vetá-la integralmente, o que significava aplicar a lei orçamentária do ano anterior, e não o projeto como originalmente enviado". 
deputados e senadores no exame da lei orçamentária, apenas um pouco menos poderosa do que durante o regime militar.

\section{(1) a organização da ANC e questões de método}

Pouco antes de morrer, em abril de 1985, o presidente Tancredo Neves combinou, com o jurista Afonso Arinos, a criação de uma comissão para iniciar os trabalhos em torno de uma nova Constituição para o país, em substituição à de 1967 (emendada pelos militares em 1969). Mesmo com a morte de Tancredo, seu vice, José Sarney, "pisando em ovos" (Lamounier 2008, p. 20), optou por instalar esta comissão, conhecida como Comissão Afonso Arinos. Foi produzido um anteprojeto constitucional que não saiu das gavetas dos gabinetes parlamentares da época, mas o debate havia iniciado e guiou a eleição dos parlamaentares constituintes no fim de 1986. Em janeiro de 1987, iniciou-se a ANC.

A Assembléia Nacional Constituinte foi inicialmente organizada em 8 comissões com 63 membros cada, cada uma delas subdividida em 3 subcomissões sem número específico de parlamentares estabelecido pelo Regimento Interno (Resolução 2/1987). A área de finanças públicas foi considerada na Comissão do Sistema Tributário, Orçamento e Finanças. As três subcomissões a ela ligadas foram denominadas Subcomissão sobre Tributos, Participação e Distribuição das Receitas; Subcomissão sobre Sistema Financeiro e, a que mais interessa para este texto, Subcomissão sobre Orçamento e Fiscalização Financeira. Cada subcomissão realizou audiências públicas e designou um relator responsável pela elaboração de um pré-projeto da área, emendado por parlamentares e com sua versão final ratificada pelo plenário da subcomissão. Em seguida, a Comissão do Sistema Tributário, Orçamento e Finanças recebeu esses anteprojetos das subcomissões e elaborou um texto final, analisado - e em parte alterado - pela Comissão de Sistematização em suas diversas etapas. A Comissão de Sistematização enviou um projeto para o plenário e, após 732 votações nominais ocorridas apenas no primeiro turno (de janeiro a junho de 1988), foi aprovada integralmente a Constituição Federal em outubro de 1988.

Com essa organização legislativa descentralizada e diversas instâncias potenciais de veto ao longo de todo o processo constituinte, poucos analistas conferem às comissões e subcomissões papel relevante na definição dos assuntos consagrados na Constituição. O relato acadêmico mais comum sobre a ANC costuma partir de sua 
instalação e a subseqüente aprovação do Regimento Interno elaborado pelo senador peemedebista Fernando Henrique Cardoso. Este primeiro regimento dividiu os trabalhos em oito comissões temáticas, separadas em vinte e quatro subcomissões. Após esta etapa descentralizada, instalou-se uma poderosa Comissão de Sistematização, incumbida de elaborar um Anteprojeto de Constituição a ser então apreciado pelo plenário do Congresso Nacional. Ao líder do PMDB, senador Mário Covas, foi dada a prerrogativa de indicar relatores e presidentes para a maioria das comissões e subcomissões temáticas, algo que resultou em grande poder para grupos progressistas de dentro e fora do PMDB.

A partir de suas trincheiras nas relatorias, os progressistas avançaram agendas políticas contrárias aos interesses da maioria do plenário. Esta Constituição, que sobrerepresentou os interesses da esquerda, tornou-se ainda mais progressista na Comissão de Sistematização, na qual os relatores tinham assento cativo. Contra ela, mobilizaram-se 319 parlamentares ${ }^{59}$, em sua maioria governistas e conservadores, formando um grupo apelidado de "Centrão". Este grupo político, maioria potencial em plenário, provocou uma guinada na ANC, pois a partir da mudança do regimento interno por eles proposto foi possível levar todos os dispositivos elaborados nas comissões sob maior influência dos progressistas para nova votação em plenário. O Centrão então aprovou substitutivos aos títulos do Anteprojeto da Comissão de Sistematização, mudando a chave ideológica da ANC de centro-esquerda para centro-direita e alterando o perfil da Carta em muitos pontos. Aos grupos mais progressistas e às dissidências pontuais no Centrão, coube lutar por alterações textuais através de Destaques de Votação e Destaques de Votação em Separado (os DVSs).

Esta avaliação sobre o processo constituinte é compartilhada em seus pontos básicos pela literatura em geral (Coelho 1999, Gomes 2006, Martinez-Lara 1996, Pilatti 2008, Souza 2003, Vianna Lopes 2008; exceções são Diniz e Noronha 2008; Limongi 2008; Praça $2008^{60}$ ), mas os autores dão diferentes ênfases aos nós condutores da narrativa. Os trabalhos mais contemporâneos à Constituinte acompanharam o diagnóstico geral da ciência política sobre o sistema político brasileiro durante a década de 90: criticaram a fragmentação do Congresso Nacional, a pouca coesão dos partidos políticos e a dificuldade de eles organizarem os parlamentares dentro de um espectro ideológico claro.

\footnotetext{
${ }^{59}$ Signatários do Projeto de Resolução 20/1987, que propunha a alteração do Regimento Interno da ANC

${ }^{60}$ Estes autores avaliam que o Centrão foi menos forte do que a literatura costuma afirmar.
} 
Nessa visão, as decisões tomadas durante o processo foram frutos de coalizões suprapartidárias ad hoc, formadas em plenário. Vale citar Martinez-Lara (1996, p. 195196: "A falta de unidade e disciplina entre os principais partidos tornou a formação de coalizões interpartidárias inviável. Contudo, coalizões ideologicamente soltas através das fronteiras partidárias foram informalmente criadas (...). Porém, essas coalizões não eram de forma alguma estáveis ou consistentes. Elas precisavam ser formadas e reformadas de acordo com o problema em questão, envolvendo realinhamentos artigo por artigo e por vezes palavra por palavra".

Dentro dessa percepção de acentuada fragmentação partidária, e tendo em vista o longo processo de 1.021 votações em plenário após a mudança do regimento, os primeiros trabalhos focaram no plenário da Constituinte, na tentativa de mapear as preferências individuais dos parlamentares e a coesão dos partidos, destacando o dissenso entre os constituintes (Kinzo 1990, Mainwaring e Pérez-Liñan 1997, Lamounier 1989, DIAP 1988, Fleischer e Marques 1999; para uma perspectiva oposta, ver Coelho 1999).

Implicitamente ou explicitamente, as análises sobre a ANC de 1987-1988 tomam como variável dependente o texto constitucional e como variável independente a mudança do Regimento Interno e a criação do Centrão durante o processo constituinte. A hipótese se assenta sob um forte pressuposto teórico de que a mudança nas regras do jogo alterou sensivelmente os recursos de poder disponíveis aos jogadores e, portanto, o resultado final. A maioria dos estudos empíricos que se propuseram a verificar a variável dependente, contudo, se limitaram a estudos de caso.

Existem dois tipos de trabalhos sobre a ANC que envolveram estudos de caso: aqueles cujo objeto principal era a própria Constituinte e a interação das instituições políticas durante a Constituinte (Martinez-Lara 1996, Gomes 2006, Pilatti 2008, Souza 2003, Coelho 1999) e aqueles que tinham como objeto alguma política pública ou instituição política específica, e estudaram a ANC para entender como determinada instituição foi mantida, reformada ou produzida durante seus dois longos anos (Dantas 2008, Diniz e Noronha 2008, Limongi 2008, Madureira e Jard 2008, Oliveira 2008, Praça 2008, Souza 2001).

O primeiro tipo de estudo é o mais influente na caracterização da ANC. Também são os estudos mais afeitos à narrativa que resumimos acima. O segundo grupo de análises por vezes dá maior ênfase à continuidade e ao consenso durante a ANC, reforçando também o papel das comissões e subcomissões temáticas. No entanto, 
continua bastante tributário da matriz teórica dos estudos do primeiro grupo, que forneceram o tom da narrativa específica sobre a constituinte.

Outra característica que diferencia esse dois tipos de estudos é o critério para a escolha dos casos estudados. Nos estudos do segundo grupo a seleção era em função do tema pesquisado (trabalhismo, previdência etc.). Nos estudos do primeiro grupo, contudo, alguma definição mais substancial de critério era necessária, tendo em vista serem estudos que buscam explicar todo o processo constituinte. Nesses, a seleção se deu, implicitamente, em função do alto grau de controvérsia e de polarização ideológica dos temas escolhidos. Ou seja, houve viés de seleção.

A escolha de casos pela variável dependente não é necessariamente um problema, argumentam Collier e Mahoney (1996) ${ }^{61}$. Este tipo de escolha pode ser útil para testar teorias e identificar outras variáveis relevantes para explicar o fenômeno sob análise, sobretudo quando a consideração do universo total de casos é proibitiva ${ }^{62}$.

Diversos trabalhos que se tornaram referências indispensáveis para estudiosos do processo constituinte brasileiro escolheram casos a estudar de acordo com seu "alto grau de controvérsia, tal qual sugerido pela maioria dos meus entrevistados, particularmente pelo relator-geral da ANC, Bernardo Cabral" (Martinez-Lara 1996, p. 3), e "dissenso ao longo das quatro fases deliberativas em que foram apreciados, traduzido pela elevada polarização das votações entre posições ideológicas de direita e de esquerda" (Pilatti, 2008, p. 7). Escolher casos por critérios de controvérsia significa ignorar assuntos sobre os quais decisões foram tomadas e inalteradas ao longo do processo constituinte. A principal hipótese explicativa associada a estes trabalhos é a de que o novo Regimento Interno da ANC, proposto pelo Centrão, aprovado em dezembro de 1987, provocou mudanças substantivas em todo o texto constitucional. No entanto, o foco em "alguns dos resultados mais comentados na mídia e na literatura, ainda que sejam resultados parciais" (Gomes, 2006, p. 212), resulta na generalização, apoiada na confirmação desta hipótese para os casos selecionados, de que "a Constituição Federal teria sido bem diferente da que foi promulgada" (Gomes, 2006, p. 218) se o Regimento Interno não houvesse sido mudado.

Continuando o diálogo com a autora, ela afirma que "nas três votações nominais selecionadas [duração do mandato presidencial, sistema de governo, indenização ao

\footnotetext{
${ }^{61}$ Visão oposta é apresentada por Geddes (2003) e King, Keohane e Verba (1994).

${ }^{62}$ Nesse sentido, Gomes (2006, p. 212) argumenta que "uma avaliação completa de todas as vitórias e derrotas para diferentes questões e grupos políticos está fora do alcance deste artigo...”.
} 
empregado em caso de despedida arbitrária], a preferência da maioria dos membros da Comissão de Sistematização foi oposta àquela atingida em plenário" (Gomes, 2006, p. 203). Para estes casos, é bastante defensável o argumento de que a mudança nos procedimentos constituintes resultou em alterações substantivas no texto. No entanto, pode-se imaginar uma pletora de assuntos em torno dos quais a preferência dos parlamentares em etapas anteriores da Constituinte - subcomissões, comissões e Comissão de Sistematização - não se alterou no plenário. Nesses casos, portanto, a mudança institucional não resultou em efeitos substantivos.

Essa falta de variação da saliência dos assuntos estudados por esses autores não seria um grande problema caso eles "cuidadosamente definissem e limitassem o alcance de seus achados para uma população específica de casos que compartilham as mesmas características-chave dos casos analisados” (George e Bennett, 2005, p. 25).

Porém, tanto Pilatti (2008, p. 8), ao afirmar que busca "estruturar um retrato explicativo de todo o Processo Constituinte de 1987-88" quanto Gomes (2006, p. 217), ao dizer que se "não fosse a formação de uma coalizão de veto, mais à direita do espectro ideológico, que exigia a reforma do regimento interno, a Constituição Federal teria sido bem diferente da que foi promulgada", fazem generalizações para todo o texto constitucional a partir de casos de alta saliência. É verdade que em muitos pontos os autores fazem ressalvas quanto ao impacto global do plenário e da mudança de regimento, especialmente na caracterização do Centrão como uma "coalizão de veto". Nessa descrição do Centrão, ele é apresentado como um grupo de parlamentares essencialmente conservador que, apesar de constituírem uma maioria numérica, não conseguiram articular um projeto completo de Constituição. Mesmo assim, a imagem da ANC que fica de assertivas como as citadas acima, assim como da ilustração geral dos estudos de caso, é a de duas Constituintes: antes e depois do regimento.

A narrativa descrita acima do processo constituinte será tanto mais válida quanto mais saliente for o assunto em questão. Assim, definições sobre assuntos menos polêmicos podem ter passados incólumes por todo o processo constituinte. O que explica mudanças ou continuidades ao longo do processo constituinte para assuntos menos salientes, como o processo orçamentário? A definição de instituições orçamentárias não mudou significativamente de uma etapa para outra desta critical juncture por não ser um assunto saliente, mobilizador de preferências intensas da imensa maioria dos parlamentares. 
A próxima seção do texto é dedicada ao índice de saliência externa construído a partir de análise da revista Veja de 1986 a 1988, que permitirá identificar os assuntos mais importantes à época da Assembléia Nacional Constituinte.

\section{(2) Saliência de assuntos políticos à época da Assembléia Nacional Constituinte}

A dinâmica da saliência de assuntos na agenda política tem sido bastante estudada por Baumgartner e Jones (1993, 2002), com perspectiva semelhante, em diversos aspectos, à iniciada por Kingdon ${ }^{63}$ (1995). De acordo com essa visão, a saliência relativa de um assunto ao longo do tempo é determinante para a circulação de alternativas políticas sobre esse assunto. Quanto mais um assunto político é tido como saliente pela população e/ou pela elite política, mais idéias relativas a esse assunto circularão na agenda e mais provável será a mudança política, embora esta seja obviamente influenciada por muitos outros fatores.

A intenção aqui é obter uma medida de saliência relativa de assuntos políticos na mídia durante o período em que ocorreu a Assembléia Nacional Constituinte que promulgou a Constituição Federal de 1988. O ideal seria obter uma medida da saliência dos assuntos para os próprios constituintes, algo que não consegui fazer ainda.

É sabido que certos temas mereceram muito mais atenção - tanto da opinião pública quanto dos parlamentares constituintes - do que outros. Tanto analistas quanto figuras importantes do jogo político da época concordam que assuntos como a definição do sistema de governo, a duração do mandato do presidente, a reforma agrária, os direitos trabalhistas e poucos outros foram os mais relevantes nos debates, dividindo partidos e mobilizando interesses fortemente afetados pelas escolhas políticas. Até onde conheço, no entanto, nenhum estudioso ou político revela justificativas menos do que etéreas para citar esses temas, indicando que apenas reproduzem certo zeitgeist.

Isso dificulta a comprovação - ou refutação - da hipótese segundo a qual a saliência relativa de um assunto constituinte foi determinante para a definição final da assembléia em torno deste assunto. Em outras palavras, minha hipótese é a de que um assunto muito saliente na mídia da época recebeu mais atenção e mudanças ao longo do processo constituinte do que um assunto menos saliente. Para testar isso em relação ao caso do desenho orçamentário definido pelos constituintes, proponho um índice de

\footnotetext{
${ }^{63}$ Capella (2006) revisa esta literatura.
} 
saliência externa relativa, utilizando 235 reportagens publicadas pela revista semanal Veja de 22/1/1986 a 12/10/1988. O índice é construído a partir de 687 menções a 101 assuntos políticos feitas pela revista no período ${ }^{64}$. Assuntos mais mencionados são identificados como relativamente mais salientes do que outros pouco - ou nunca citados pela revista.

Diversas críticas podem ser feitas a este índice. Uma delas é a de que certo viés ideológico da revista, tida como conservadora, exclui automaticamente certos assuntos. Miguel (1999) já mostrou que a Rede Globo, em seu programa jornalístico de maior audiência, sistematicamente ignorou temas políticos que poderiam prejudicar a reeleição do presidente Fernando Henrique Cardoso em 1998. No entanto, assuntos associados a uma perspectiva menos do que conservadora, como a reforma agrária e direitos trabalhistas, foram cobertos pela revista, como mostra a tabela 1 abaixo. Não interessa saber, para os fins deste capítulo, como a revista se posicionou sobre eles, mas simplesmente quão saliente esses e outros temas eram no debate político da época.

Outra crítica possível é a de que a utilização de uma revista semanal para construir o índice mascara assuntos importantes que estavam presentes na imprensa diária e não na semanal. Certamente uma análise de jornais como Folha de S. Paulo, O Estado de $S$. Paulo e $O$ Globo refinaria o índice de saliência externa aqui proposto. No entanto, seria surpreendente se a partir desta análise encontrássemos resultados muito diferentes, dada a maneira como mídia diária e semanal se influenciam e repetem assuntos, em uma dinâmica que Bourdieu (1997, p. 30-31) denominou "circulação circular da informação". Assuntos bastante cobertos pela Veja provavelmente não foram ignorados pelos jornais diários e vice-versa. A tabela 3.1 abaixo mostra os temas mais citados pela revista no período.

\footnotetext{
${ }^{64}$ Excluí da tabela as 74 menções a temas internos à Assembléia Nacional Constituinte, como os debates sobre o regimento interno.
} 
Tabela 3.1: Saliência dos assuntos políticos na Veja, 1986-1988

\begin{tabular}{|l|l|}
\hline Assunto & \% de menções \\
\hline Mandato presidencial & 9,78 \\
\hline Forma de governo & 8,80 \\
\hline Reforma agrária & 5,22 \\
\hline Estabilidade do contrato de trabalho & 4,89 \\
\hline Nacionalismo econômico & 4,07 \\
\hline Privatização/estatização & 3,42 \\
\hline Forma da constituição & 3,42 \\
\hline Licenças maternidade-paternidade & 3,26 \\
\hline Jornada de trabalho & 3,09 \\
\hline Repartição de recursos na federação & 2,93 \\
\hline Direito de greve & 2,93 \\
\hline Taxa de juros tabelada & 2,77 \\
\hline Direitos individuais fundamentais & 2,77 \\
\hline Pluralismo sindical & 1,95 \\
\hline Índice de reajuste e valor da aposentadoria & 1,95 \\
\hline Carga tributária & 1,63 \\
\hline Poderes legislativos do presidente & 1,46 \\
\hline Aborto e inseminação artificial & 1,46 \\
\hline Papel dos militares & 1,46 \\
\hline Livre iniciativa & 1,30 \\
\hline Outros temas, com menos de sete menções & 31,44 \\
\hline Total & $\mathbf{1 0 0}$ \\
\hline
\end{tabular}

* Assuntos com sete ou menos menções: Isenção de impostos aos sindicatos; vinculação de receitas da União; IVV municipal; Mandato do presidente do banco central; restrição a atividades financeiras; elaboração do orçamento; composição do Tribunal de Contas; limitação de gastos com pessoal; reserva de vagas nas escolas; jogos de azar; ensino religioso; verba para escolas particulares; igualdade na relação conjugal; pátrio poder e poder familiar; planejamento familiar; criação de estados; imposto estadual sobre operações financeiras; imposto estadual sobre lucro das empresas; criação de municípios; imposto municipal sobre venda de combustíveis; propriedades rurais e a penhora para empréstimos bancários; pleno emprego; patentes; participação política direta; acesso a arquivos públicos; defensoria pública; descentralização do poder judiciário; corte constitucional; avocatória no STF; Superior Tribunal de Justiça; ação direta de inconstitucionalidade; trabalho infantil; direito a passeatas e protestos; reeleição; segurodesemprego; representante sindical; liberdade sindical; igualdade de salário homem e mulher; aposentadoria para donas de casa; regime de trabalho de funcionários públicos; idade da aposentadoria; racismo; terras indígenas; terras quilombolas; imprescritibilidade das ações trabalhistas; imposto sobre a herança; aumento do imposto de renda; repasse do IPI para os estados; concentração urbana e especulação imobiliária; usucapião; defesa do meio ambiente; estado de exceção; conselho de segurança nacional; serviço militar obrigatório; união das polícias; tráfico de drogas; dívida externa; imposto sindical; sigilo das informações; anistia das dívidas rurais; valor do salário, reajuste e parcelas; família; sistema eleitoral; criação do ICM; concessões de rádio e TV; repasse do IR para estados; imposto sobre fortunas; anistia; liberdade de expressão; adicional de férias; adicional de horas extras; divórcio.

O processo orçamentário foi citado apenas 3 vezes, totalizando menos de $0,5 \%$ das menções a assuntos políticos na revista. Fatores que podem explicar esta baixa saliência externa são: a) centralidade do debate político da época à definição do sistema de governo do país; b) a alta inflação do período tornava o processo orçamentário incerto e, em grande medida, inútil para o planejamento econômico e político do país. Poder-se-ia argumentar que as pouquíssimas menções ao processo orçamentário foram encontradas devido a um viés jornalístico de tratar de temas mais substantivos do que processuais. Para verificar isso, subdividi os 101 assuntos políticos em referentes à polity (definições de Estado e Nação; direitos individuais de liberdade e de participação política; regras do jogo político; direitos materiais orientados para o bem-estar e a igualdade) e a policies, na conhecida tipologia de Couto e Arantes (2006). 57\% das menções feitas pela revista 
Veja trataram de assuntos referentes à polity.? A baixa saliência externa do processo orçamentário, portanto, não é explicada pela pouca atenção ao desenho das instituições políticas em geral.

\section{(3) A escolha dos relatores das subcomissões e seus poderes}

Tendo estabelecido que diferentes assuntos mereceram atenção desigual dos parlamentares constituintes, a julgar pelo índice de saliência externa exposto na seção anterior, cabe agora analisar se a escolha dos relatores das 8 comissões e 24 subcomissões foi, de certo modo, influenciada pela saliência relativa dos assuntos. Posteriormente, esta seção analisará as prerrogativas dos relatores das subcomissões e, especificamente em relação à Subcomissão de Orçamento e Fiscalização Financeira, a composição da subcomissão e o que poderíamos esperar do relator.

Organizei os 101 assuntos políticos tratados pela Veja de acordo com as 24 subcomissões designadas no primeiro Regimento Interno da Assembléia Nacional Constituinte, a Resolução 2/1987. Dada a omissão deste regimento sobre as áreas de competências de cada subcomissão, alguns assuntos foram tratadas por mais de uma subcomissão. Escolhi ligar os assuntos às subcomissões que intuitivamente lhes parecem mais pertinentes - o sistema de governo a ser adotado no Brasil, por exemplo, foi alocado para a quota de assuntos da Subcomissão do Poder Executivo, e não a Subcomissão da Nacionalidade, Soberania e Relações Internacionais - apesar desta também ter tratado do assunto em seu anteprojeto. A tabela 3.2 abaixo mostra a saliência relativa dos assuntos políticos tratados por cada subcomissão. 
Tabela 3.2: Comando das subcomissões da ANC e saliência dos assuntos, 1986-1988

\begin{tabular}{|c|c|c|c|}
\hline Subcomissão & Saliência $^{65}$ & Presidente & Relator \\
\hline $\begin{array}{l}\text { Subcomissão dos Direitos dos Trabalhadores e Servidores } \\
\text { Públicos }\end{array}$ & 23,32 & PMDB & PMDB \\
\hline Subcomissão do Poder Executivo & 20,55 & PMDB & PMDB \\
\hline $\begin{array}{l}\text { Subcomissão dos Tributos, Participação e Distribuição de } \\
\text { Receitas }\end{array}$ & 10,7 & PFL & PMDB \\
\hline $\begin{array}{l}\text { Subcomissão dos Princípios Gerais, Intervenção do } \\
\text { Estado, Regime de Propriedade do Subsolo e da } \\
\text { Atividade Econômica }\end{array}$ & 9,13 & PDS & PMDB \\
\hline Subcomissão dos Direitos e Garantias Individuais & 6,85 & PMDB & PDS \\
\hline $\begin{array}{l}\text { Subcomissão de Política Agrícola e Fundiária e da } \\
\text { Reforma Agrária }\end{array}$ & 6,19 & PFL & PMDB \\
\hline Subcomissão do Sistema Financeiro & 3,75 & PMDB & PMDB \\
\hline Subcomissão da Família, Menor e Idoso & 3,58 & PMDB & PFL \\
\hline $\begin{array}{l}\text { Subcomissão de Garantias da Constituição, Reformas e } \\
\text { Emendas }\end{array}$ & 3,42 & PMDB & PMDB \\
\hline $\begin{array}{l}\text { Subcomissão de Defesa do Estado, da Sociedade e de Sua } \\
\text { Segurança }\end{array}$ & 2,61 & PMDB & PFL \\
\hline Subcomissão da Ciência, Tecnologia e Comunicação & 1,79 & PFL & PMDB \\
\hline Subcomissão da Educação, Cultura e Esportes & 1,30 & PMDB & PMDB \\
\hline Subcomissão do Poder Judiciário e Ministério Público & 1,14 & PMDB & PT \\
\hline Subcomissão do Sistema Eleitoral e Partidos Políticos & 0,97 & PMDB & PTB \\
\hline $\begin{array}{l}\text { Subcomissão dos Direitos Políticos, Direitos Coletivos e } \\
\text { Garantias }\end{array}$ & 0,97 & PMDB & PDT \\
\hline $\begin{array}{l}\text { Subcomissão dos Negros, Populações Indígenas, } \\
\text { Deficientes e Minorias }\end{array}$ & 0,81 & PMDB & PFL \\
\hline Subcomissão do Orçamento e Fiscalização Financeira & $\mathbf{0 , 8 1}$ & PFL & PDS \\
\hline Subcomissão da Questão Urbana e Transportes & 0,65 & PMDB & PMDB \\
\hline Subcomissão dos Estados & 0,64 & PMDB & PDC \\
\hline Subcomissão dos Municípios e Regiões & 0,32 & PMDB & PFL \\
\hline Subcomissão da Saúde, Seguridade e Meio Ambiente & 0,32 & PTB & PMDB \\
\hline Subcomissão da União, Distrito Federal e Territórios & 0 & PFL & PMDB \\
\hline Subcomissão do Poder Legislativo & 0 & PDT & PFL \\
\hline \multirow[t]{2}{*}{$\begin{array}{l}\text { Subcomissão da Nacionalidade, Soberania e Relações } \\
\text { Internacionais }\end{array}$} & 0 & PDT & PMDB \\
\hline & $100 \%$ & & \\
\hline
\end{tabular}

As subcomissões que agregam assuntos de maior saliência tratam de temas já mencionados por estudiosos e figuras políticas da época como relevantes. Nota-se, também, que das sete subcomissões que tratam de assuntos de maior saliência, seis tiveram relator do PMDB. Coelho (1999, p. 133-134) observa que "a aplicação do princípio da proporcionalidade a todas as comissões e subcomissões viria beneficiar claramente o PMDB, que sendo o partido majoritário na Constituinte garantiria assim para si a maioria em todas as comissões, além também da maioria das presidências,

${ }^{65}$ Porcentagem de menções dos assuntos tratadas em cada subcomissão pela revista Veja no periodo analisado. 
vice-presidências e relatorias. Se não houvesse a obrigatoriedade da proporcionalidade partidária em todas as comissões e subcomissões, haveria a possibilidade de um partido que tivesse uma preferência muito intensa em uma determinada área temática concentrar seus membros em uma comissão ou subcomissão específica, tornando-se assim nela majoritário". Na Subcomissão do Orçamento e Fiscalização Financeira provavelmente ocorreu o contrário: a preferência pouco intensa pelo assunto permitiu a indicação de um relator conservador ${ }^{66}$. Ou Mário Covas e o PMDB progressista não se importavam com a definição do processo orçamentário ou confiavam que José Serra conseguiria impor suas preferências como relator da Comissão do Sistema Tributário, Orçamento e Finanças. Volto a este ponto posteriormente no texto.

É interessante assinalar que, de acordo com Gomes (2006, p. 203), o senador Mário Covas (PMDB-SP), responsável por indicar os relatores peemedebistas nas comissões e subcomissões, "indicou membros do PMDB que eram vistos como mais à esquerda do partido para compor algumas das comissões e subcomissões da Constituinte. Mais do que isso, Covas teria indicado membros mais progressistas do partido como relatores nas subcomissões e comissões temáticas”. A tabela 3.3 abaixo compara, tomando como parâmetro a classificação ideológica de parlamentares proposta pelo Departamento Intersindical de Assessoria Parlamentar (DIAP, 1988), a posição ideológica de cada relator de cada subcomissão comparada à posição ideológica média de seu partido em plenário. A classificação do DIAP confirma o argumento de Gomes (2006) para 18 dos 24 relatores de subcomissões, localizados à esquerda do seu partido em plenário.

\footnotetext{
${ }^{66}$ O mesmo autor não cita o tema do orçamento como prioritário para o PDS na Constituinte: "A alocação dos parlamentares pedessistas pelas diferentes subcomissões mostra claramente a preocupação do partido com a questão da propriedade dos meios de produção, o que se explica tanto pela localização ideológica do partido no espectro direita-esquerda, quanto pela composição social de sua bancada, em que os empresários eram maioria" (Coelho 1999, p. 163).
} 
Tabela 3.3: Posição ideológica dos relatores das subcomissões da Assembléia Nacional Constituinte

\begin{tabular}{|l|l|l|}
\hline Subcomissão & Relator & Partido do Relator \\
\hline $\begin{array}{l}\text { Subcomissão da Comissão da Família, Educação, Cultura, Esportes, } \\
\text { Ciência, Tecnologia e Comunicação }\end{array}$ & 10 & 5,64 \\
\hline Subcomissão da Educação, Cultura e Esportes & 4,75 & 5,64 \\
\hline Subcomissão da Família, Menor e Idoso & 0,25 & 2,54 \\
\hline Subcomissão dos Estados & 5,75 & 3,50 \\
\hline Subcomissão dos Municípios e Regiões & 1,75 & 2,54 \\
\hline Subcomissão da União, Distrito Federal e Territórios & 10 & 5,64 \\
\hline Subcomissão de Política Agrícola e Fundiária e da Reforma Agrária & 10 & 5,64 \\
\hline $\begin{array}{l}\text { Subcomissão dos Princípios Gerais, Intervenção do Estado, Regime } \\
\text { de Propriedade do Subsolo e da Atividade Econômica }\end{array}$ & 7,75 & 5,64 \\
\hline Subcomissão da Questão Urbana e Transportes & 5,75 & 5,64 \\
\hline $\begin{array}{l}\text { Subcomissão de Defesa do Estado, da Sociedade e de Sua } \\
\text { Segurança }\end{array}$ & 0,25 & 2,54 \\
\hline Subcomissão de Garantias da Constituição, Reformas e Emendas & 10 & 5,64 \\
\hline Subcomissão do Sistema Eleitoral e Partidos Políticos & 10 & 6,32 \\
\hline Subcomissão do Poder Executivo & 9,25 & 5,64 \\
\hline Subcomissão do Poder Judiciário e Ministério Público & 10 & 9,95 \\
\hline Subcomissão do Poder Legislativo & 4,75 & 2,54 \\
\hline Subcomissão dos Direitos dos Trabalhadores e Servidores Públicos & 9,25 & 5,64 \\
\hline $\begin{array}{l}\text { Subcomissão dos Negros, Populações Indígenas, Deficientes e } \\
\text { Minorias }\end{array}$ & 3,75 & 2,54 \\
\hline Subcomissão da Saúde, Seguridade e Meio Ambiente & 8,5 & 5,64 \\
\hline Subcomissão dos Direitos e Garantias Individuais & 0,75 & 2,67 \\
\hline Subcomissão dos Direitos Políticos, Direitos Coletivos e Garantias & 9,75 & 9,10 \\
\hline $\begin{array}{l}\text { Subcomissão da Nacionalidade, Soberania e Relações } \\
\text { Internacionais }\end{array}$ & 10 & 5,64 \\
\hline Subcomissão do Orçamento e Fiscalização Financeira & $\mathbf{3 , 2 5}$ & $\mathbf{2 , 6 7}$ \\
\hline Subcomissão do Sistema Financeiro & 4 & 5,64 \\
\hline Subcomissão dos Tributos, Participação e Distribuição de Receitas & 5,75 & 5,64 \\
\hline Média ANC (4,10) & 6,46 & 5,00 \\
\hline Fonte DIAP. 0 Direita, 10 Esquer & \\
\hline
\end{tabular}

Fonte: DIAP. 0 = Direita, $10=$ Esquerda.

Quão poderoso era o relator da subcomissão? Cabe reproduzir o que o Regimento Interno dispunha sobre o assunto em seu artigo 17: “O relator, na subcomissão, com ou sem discussão preliminar, elaborará seu trabalho com base nos subsídios encaminhados nos termos do estabelecido neste Regimento, devendo, no prazo de trinta dias, apresentar relatório fundamentado como anteprojeto da matéria. O anteprojeto será distribuído, em avulsos, aos demais membros da subcomissão para, no prazo de cinco dias seguintes, destinados à discussão, receber emendas. Encerrada a discussão, o relator terá 72 horas para emitir parecer sobre as emendas, sendo estas e o anteprojeto submetidos à votação. As emendas rejeitadas serão arquivadas, podendo, entretanto, ser reapresentadas nas demais fases da elaboração da Constituição. A subcomissão, a partir de sua constituição, terá um prazo de 45 dias para encaminhar à respectiva comissão o 
anteprojeto por ela elaborado e, não o fazendo, caberá ao relator da comissão redigi-lo no prazo de cinco dias".

Dada a grande quantidade de assuntos a tratar em cada subcomissão, podemos esperar que o relator da subcomissão tenha tido razoável poder como agenda setter, ao ser o primeiro ator político a propor normas constitucionais para cada área. Sabemos, desde o seminal trabalho de Baron e Ferejohn (1989), que o poder de propor a primeira versão de uma peça legislativa não é algo a ser minimizado. Ainda que outros parlamentares possam emendar esta primeira versão - adicionando itens, suprimindo outros -, não é razoável imaginar que todos irão propor algo que contraria enormemente o anteprojeto inicial do relator.

Há diversas razões para isso. Em primeiro lugar, é razoável esperar que o relator tenha escrito a primeira versão de seu anteprojeto considerando interesses e opiniões de outros membros da subcomissão, pois ele sabe que uma maioria é necessária para aprová-lo. Em segundo lugar, os demais parlamentares sabem que o relator está melhor informado sobre a opinião da maioria da subcomissão, tornando qualquer proposta alternativa custosa - pois seria necessário angariar apoio de outra maioria - e menos legítima, pois não terá sido proposta pelo relator formal.

Considerando essas condições, o relator pode usar sua posição institucional de modo estratégico, incluindo em seu anteprojeto itens que ele considera de interesse da maioria e desenhando este anteprojeto de modo a incluir, também, preferências que o interessam especialmente - de maneira mais ou menos explícita. Veremos, na quinta seção deste texto, as preferências do relator sobre emendamento ao orçamento e existência e atribuições da Comissão Mista de Orçamento. Por ora, cabe apenas assinalar que a Subcomissão do Orçamento e Fiscalização Financeira teve relator (José Luiz Maia) e presidente (João Alves), ambos conservadores. A tabela 3.4 mostra algumas informações sobre os membros da subcomissão. Embora à esquerda do plenário, é relativamente conservadora. 
Tabela 3.4: Posição ideológica da Subcomissão de Orçamento da ANC, 1987

\begin{tabular}{|l|l|l|l|}
\hline & Subcomissão & Plenário & $\begin{array}{l}\text { Número de } \\
\text { integrantes }\end{array}$ \\
\hline PMDB & 6,04 & 5,64 & 10 \\
\hline PDS & 3,25 & 2,67 & 1 (relator) \\
\hline PFL & 2,3 & 2,56 & 4 (presidente) \\
\hline PTB & 2 & 6,32 & 2 \\
\hline PL & 1 & 4,80 & 1 \\
\hline PDT & 4 & 9,10 & 1 \\
\hline & $\mathbf{4 , 4 7 5}$ & $\mathbf{4 , 1 0 2}$ & $\mathbf{1 9}$ \\
\hline
\end{tabular}

* Fonte: Diap 1988. 0 = Direita, $10=$ Esquerda.

\section{(4) Interesses legislativos coletivos e decisões constituintes}

O objetivo desta seção é identificar os principais interesses legislativos em circulação durante a Assembléia Nacional Constituinte e como eles influenciaram as decisões sobre o desenho do processo orçamentário. Seguindo Schickler (2001), defino como interesses legislativos os interesses que podem explicar a atuação de parlamentares e que são formados a partir de incentivos da arena eleitoral, da arena partidária e da arena institucional interna ao Legislativo. No primeiro capítulo desta tese, observei que os parlamentares brasileiros normalmente agem de acordo com três interesses de curto prazo (reeleição, acesso a postos de poder institucional, pertencimento à coalizão/oposição) e um interesse de longo prazo (Legislativo como ator coletivo).

No entanto, os interesses legislativos que operam em uma Assembléia Constituinte são razoavelmente diferentes dos que podemos normalmente encontrar no Legislativo brasileiro. Não é demais supor, como faz Elster (1998), que parlamentares constituintes trabalhem com menos vistas à reeleição do que em uma legislatura normal. Podemos esperar também que o interesse dos parlamentares em fortalecer o Legislativo como ator coletivo é grande, sobretudo considerando que no período militar o Congresso foi fechado diversas vezes. Do mesmo modo, o interesse em desenhar postos institucionais fortes dentro do Legislativo tende a ser ativo durante a Assembléia Constituinte e apenas reativo durante uma legislatura normal, na qual basta manter o desenho institucional vigente. Interesses determinados pelo pertencimento à coalizão ou oposição tendem a ser fraquíssimos durante uma Assembléia Constituinte e fortíssimos durante uma legislatura normal, na qual o pertencimento à coalizão pode significar acesso privilegiado a benesses oferecidas pelo Executivo.

Pode-se identificar, ainda, um interesse conservador presente na Constituinte. Trata-se do interesse em manter, ao menos parcialmente, instituições políticas 
desenhadas durante a ditadura militar que vigorou no país de 1964 a 1985 . Embora o PMDB tenha obtido ampla maioria na Constituinte, partidos como PFL e PDS, associados ao regime político anterior, tiveram voz e caneta para expressar preferências por certas políticas (e desenhos institucionais) em detrimento de outras. Esse interesse conservador é favorecido pela inércia institucional, fenômeno razoavelmente comum que afeta instituições políticas ${ }^{67}$. Qualquer status quo é difícil de ser alterado, mesmo em critical junctures como a Constituinte. Além disso, parlamentares com interesses inicialmente contrários à conservação de instituições do período militar podem ter interesses que, paradoxalmente, ajudam a manter essas instituições no periodo pósmilitar.

Argumento, assim, que os três tipos de interesses legislativos mais importantes na Assembléia Nacional Constituinte foram o interesse no Legislativo como ator coletivo, o interesse no acesso a postos institucionais e o interesse de alguns em conservar algumas escolhas do período militar. Mas quais interesses legislativos explicam a escolha de certas instituições orçamentárias? Duas das escolhas constituintes mais relevantes determinaram que o Legislativo poderia emendar a proposta orçamentária do Executivo, respeitando certos limites, e que a Comissão Mista de Orçamento continuaria sendo o único locus de análise legislativa de questões referentes ao orçamento.

Antecipando parcialmente a discussão da próxima seção do texto, argumento que a decisão de permitir que parlamentares emendassem o orçamento indica forte influência do interesse em fortalecer o Legislativo como ator coletivo. Essa posição derrotou o plausível interesse conservador em manter a proposta orçamentária do Executivo insulada da interferência parlamentar, como os militares faziam. Não é difícil imaginar, neste caso, por que o interesse conservador foi derrotado, se é que foi manifestado em algum momento: a prerrogativa de emendar o orçamento é algo que agrada a todos os parlamentares indistintamente.

Além disso, os relatores da Subcomissão do Orçamento e Fiscalização Financeira e da Comissão do Sistema Tributário, Orçamento e Finanças. compartilhavam a disposição de dotar o Legislativo de poderes orçamentários. Vale citar trecho do primeiro anteprojeto da subcomissão, assinado pelo relator José Luiz Maia, do PDS: “Temos sido, lamentavelmente, um poder meramente homologatório da

\footnotetext{
${ }^{67}$ Como veremos no sexto capítulo, a inércia ou estabilidade institucional está longe de ser um processo "natural", sem interferência de atores politicos.
} 
vontade do Executivo. Vinte anos de exceção castraram nossa capacidade participativa, minimizaram a presença de nossa voz nas decisões nacionais, tiraram-nos o direito de opinar sobre os dispêndios públicos. $\mathrm{O}$ orçamento aqui chegava apenas para ser referendado e os pareceres e o exame legislativo serviam apenas para convalidar o arbítrio. O sistema de fiscalização e controle, em que pese ao Tribunal de contas da União permanecer constitucionalmente como órgão auxiliar deste poder, na verdade sempre se processava ao arrepio da decisão congressual. A transição que vivemos pôs fim a esse capítulo de nossa história".

Retórica peemedebista para parlamentar tão pedessista, com conteúdo ecoado, de modo mais discreto, por José Serra (PMBD-SP), em seu anteprojeto para a Comissão do Sistema Tributário, Orçamento e Finanças: “[Neste anteprojeto], mantém-se o princípio de que o Legislativo não deve substituir o Executivo em suas funções na realização da despesa pública, mas, ao mesmo tempo, considera-se crucial que o Legislativo participe efetivamente da definição das prioridades, controle e fiscalize a execução da despesa".

O caso da Comissão Mista de Orçamento é menos óbvio e mais revelador da maneira como diferentes interesses legislativos interagiram de modo a resultar na manutenção de uma instituição idealizada pelos militares. Na próxima seção veremos detidamente todas as diferentes propostas acerca da organização da tramitação legislativa do orçamento que foram consideradas nas diversas etapas da Constituinte. Cabe, por ora, ressalvar que a manutenção de uma única comissão legislativa para tratar de questões orçamentárias interessava: a) a quem defendia os interesses do Legislativo como ator coletivo, pois, em tese, uma única comissão poderia ter mais poder de barganha em relação ao Executivo do que diversas comissões desconexas; b) a quem defendia o interesse no acesso a postos institucionais, pois a Comissão Mista de Orçamento tornar-se-ia, dada a readquirida faculdade de emendar o orçamento, uma comissão fortíssima, sendo o pertencimento a ela considerado importante para garantir a reeleição ${ }^{68}$; c) a quem defendia a conservação de instituições desenhadas pelos militares - afinal, a Comissão Mista de Orçamento foi instituída em 1969 para diminuir o número de pontos de veto com os quais os militares teriam que se incomodar para carimbar a proposta orçamentária do Executivo.

\footnotetext{
${ }^{68}$ Agradeço Fernando Moutinho Ramalho Bittencourt, consultor de orçamento do Senado Federal, por chamar atenção a este aspecto durante entrevista realizada em Brasília em maio de 2008.
} 
Por motivos bastante diversos e contraditórios, portanto, a manutenção de uma forte Comissão Mista de Orçamento interessava a, não é ousado demais dizer, todos os constituintes $^{69}$.

\section{(5) Definição dos assuntos orçamentários na Assembléia Nacional Constituinte}

Os oito assuntos orçamentários cuja tramitação durante a Assembléia Nacional Constituinte detalho a seguir foram escolhidos de acordo com o número de emendas ao primeiro anteprojeto do relator da Subcomissão do Orçamento e Fiscalização Financeira que foram oferecidas a esses assuntos. 189 emendas foram propostas e 48 (25,3\%) delas foram acolhidas pelo relator da Subcomissão do Orçamento em seu anteprojeto final, aprovado pelos demais integrantes. A orientação geral da primeira versão do anteprojeto do relator não foi modificada. Cinco emendas modificavam grande parte do anteprojeto e foram rejeitadas por José Luiz Maia ${ }^{70}$.

Os oito assuntos são: a) fiscalização orçamentária; b) conteúdo das leis orçamentárias (Plano Plurianual, Lei Orçamentária Anual, Lei de Diretrizes Orçamentárias); c) normatização das finanças públicas; d) vinculação de receitas; e) regionalização dos gastos; f) Comissão Mista de Orçamento; g) emendas orçamentárias; h) limitação de despesas com pessoal.

A tramitação das escolhas sobre o processo orçamentário feitas durante a Assembléia Nacional Constituinte foi dividida em cinco etapas: i) primeiro anteprojeto do relator da Subcomissão de Orçamento e Fiscalização Financeira; ii) versão final do anteprojeto aprovado pela Subcomissão de Orçamento e Fiscalização Financeira; iii) versão final do anteprojeto aprovado pela Comissão do Sistema Tributário, Orçamento e Finanças; iv) versão final do projeto aprovado pela Comissão de Sistematização; v) Constituição Federal promulgada em outubro de 1988.

Em um primeiro momento, analisarei as duas primeiras etapas, ocorridas durante os trabalhos da Subcomissão de Orçamento e Fiscalização Financeira. A intenção é analisar como a proposta do relator da subcomissão, José Luiz Maia (PDS) foi assimilada por seus pares. As preferências iniciais do relator foram mantidas ou

\footnotetext{
${ }^{69}$ Este exemplo corrobora um dos principais raciocínios de Schickler (2001): o de que entrepreneurs que querem mudar o desenho de certa instituição legislativa conseguem este objetivo através do apelo a diversos - e às vezes contraditórios - interesses legislativos.

${ }^{70} \mathrm{O}$ regimento interno vedava a apresentação de emenda que substituísse integralmente o projeto, ou que dissesse respeito a mais de um dispositivo, a não ser que se tratasse de modificações correlatas e logicamente necessárias (Resolução 2/1987, art. 23, parágrafo $2^{\circ}$ ).
} 
substantivamente alteradas até que um anteprojeto final fosse aprovado pela subcomissão? Caso o plenário da subcomissão tenha mantido todas (ou ao menos boa parte) das preferências do relator, fica assinalada a relevância do poder inicial de propor certa preferência legislativa ${ }^{71}$. Isso indicaria também que o relator teria conseguido equacionar, com sucesso, seu interesse em manter, ao menos parcialmente, algumas instituições dos militares (já que pertence ao PDS) com o interesse em fortalecer o Legislativo, tão relevante para grande parte dos constituintes.

Caso o plenário da subcomissão não tenha apoiado as preferências iniciais do relator, ficará notado o insucesso do relator em incorporar interesses da maioria da subcomissão. É importante lembrar, nesse sentido, que não só o relator aceitou apenas $25 \%$ das emendas propostas a seu anteprojeto inicial como também o fato de o relator estar, de acordo com a classificação do DIAP, à direita da maioria da subcomissão (ver tabela 3.4). A tabela 3.5 mostra as escolhas da Subcomissão de Orçamento e Fiscalização Financeira em relação aos assuntos acima discriminados.

\footnotetext{
${ }^{71}$ A literatura sobre o Congresso norte-americano é pródiga em exemplos de casos nos quais o plenário não conseguiu derrubar decisões tomadas nas comissões, tanto por não poder emendar projetos (closed rule) quanto por não reunir a maioria necessária para vetar certas propostas. Limongi (1994) revisa esta literatura.
} 
Tabela 3.5: Escolhas da Subcomissão de Orçamento e Fiscalização Financeira sobre processo orçamentário

\begin{tabular}{|c|c|c|}
\hline Assuntos & $\begin{array}{l}\text { Primeiro anteprojeto do relator } \\
\text { da subcomissão }\end{array}$ & $\begin{array}{l}\text { Anteprojeto final aprovado pela } \\
\text { subcomissão }\end{array}$ \\
\hline $\begin{array}{l}\text { Fiscalização } \\
\text { Orçamentária }\end{array}$ & $\begin{array}{l}\text { Diversos artigos dispõem sobre } \\
\text { fiscalização e a composição e } \\
\text { competências do TCU. } \\
\text { Fiscalização cabe ao Congresso } \\
\text { com auxílio do TCU. }\end{array}$ & Igual. \\
\hline $\begin{array}{l}\text { Conteúdo das leis } \\
\text { orçamentárias: } \\
\text { PPA, LOA, LDO }\end{array}$ & $\begin{array}{l}\text { * orçamento unificado } \\
\text { * definição geral da LOA } \\
\text { * execução orçamentária } \\
\text { * créditos extraordinários }\end{array}$ & Igual. \\
\hline $\begin{array}{l}\text { Normatização das } \\
\text { finanças públicas }\end{array}$ & $\begin{array}{l}\text { Lei Complementar de Finanças } \\
\text { Públicas será instituída em até seis } \\
\text { meses após promulgação da } \\
\text { Constituição }\end{array}$ & Igual. \\
\hline $\begin{array}{l}\text { Vinculação de } \\
\text { receitas }\end{array}$ & $\begin{array}{l}\text { Vinculação é vedada, salvo se } \\
\text { prevista na Constituição }\end{array}$ & Igual. \\
\hline $\begin{array}{l}\text { Regionalização dos } \\
\text { gastos }\end{array}$ & $\begin{array}{l}\text { Orçamento deve "levar em conta } \\
\text { macro-regiões" do Brasil }\end{array}$ & Igual. \\
\hline $\begin{array}{l}\text { Comissão Mista de } \\
\text { Orçamento }\end{array}$ & $\begin{array}{l}\text { (1) Caso Executivo não apresente } \\
\text { projeto de lei orçamentária até } \\
\text { certo prazo, cabe à CMO } \\
\text { apresentá-lo } \\
\text { (2) CMO será formada por várias } \\
\text { subcomissões que representarão as } \\
\text { comissões permanentes da Câmara } \\
\text { e do Senado } \\
\text { (3) Mandato dos membros da } \\
\text { CMO será equivalente ao dos } \\
\text { membros das mesas diretoras da } \\
\text { Câmara e do Senado } \\
\text { (4) Emendas orçamentárias serão } \\
\text { oferecidas somente na CMO, que } \\
\text { terá poder conclusivo e final sobre } \\
\text { elas, salvo manifestação de } 1 / 3 \text { do } \\
\text { plenário de cada uma das casas } \\
\text { para rever o parecer da CMO sobre } \\
\text { emendas }\end{array}$ & $\begin{array}{l}\text { * Propostas (1), (2) e (3) da coluna ao } \\
\text { lado foram suprimidas } \\
* \text { Emendas orçamentárias serão } \\
\text { oferecidas somente na CMO, que terá } \\
\text { poder conclusivo e final sobre elas, salvo } \\
\text { manifestação de } 1 / 3 \text { do plenário de cada } \\
\text { uma das casas para rever o parecer da } \\
\text { CMO sobre emendas } \\
\text { * A estrutura e organização da CMO } \\
\text { serão determinadas pelo Regimento } \\
\text { Interno do Congresso Nacional }\end{array}$ \\
\hline $\begin{array}{l}\text { Emendas } \\
\text { orçamentárias }\end{array}$ & $\begin{array}{l}\text { * Têm que ser compatíveis com o } \\
\text { planejamento orçamentário } \\
* \text { Têm que indicar fontes de } \\
\text { financiamento }\end{array}$ & $\begin{array}{l}\text { * Têm que ser compatíveis com planos } \\
\text { de curto e médio prazo } \\
\text { * Não podem contrariar proposta de } \\
\text { distribuição de recursos } \\
\text { * Têm que indicar fontes de } \\
\text { financiamento } \\
\text { * Não podem alterar a natureza } \\
\text { econômica da despesa }\end{array}$ \\
\hline $\begin{array}{l}\text { Limitação de gastos } \\
\text { com pessoal }\end{array}$ & Não consta. & Igual. \\
\hline
\end{tabular}

Seis dos oito assuntos analisados foram mantidos sem mudanças na versão final do anteprojeto, aprovada por maioria no plenário da Subcomissão de Orçamento e 
Fiscalização Financeira. É notável que os dois assuntos sobre os quais mais mudanças incidiram foram as atribuições e organização da Comissão Mista de Orçamento e as emendas orçamentárias.

A Comissão Mista de Orçamento idealizada pelo relator na primeira versão de seu anteprojeto era extremamente poderosa. Caso o Executivo não apresentasse projeto de lei orçamentária até certo prazo, caberia à comissão fazê-lo. Emendas orçamentárias seriam oferecidas somente na comissão, que teria poder conclusivo e final sobre elas, salvo manifestação de um terço do plenário de cada uma das casas para rever o parecer da comissão sobre as emendas. A versão final do anteprojeto da subcomissão manteve o segundo ponto, mas suprimiu o artigo que daria à Comissão Mista de Orçamento a prerrogativa de apresentar um projeto de lei orçamentária na ausência de uma proposta do Executivo.

Ainda em relação à prerrogativa da Comissão Mista de Orçamento analisar e emitir parecer conclusivo sobre as emendas orçamentárias, é interessante destacar a emenda ao anteprojeto do relator proposta pelo senador Fernando Henrique Cardoso (PMDB-SP), suprimindo este poder da comissão. O então senador assim justificava sua proposta: "O dispositivo que se pretende suprimir foi introduzido no processo legislativo brasileiro pelo regime autoritário, visando facilitar o controle da elaboração orçamentária pelo Executivo". A emenda de Fernando Henrique Cardoso não foi acolhida pelo relator e ilustra bem a dinâmica de conflito entre interesses "próLegislativo", reativos às instituições do período militar, e os interesses “conservadores", guardiães de ao menos alguns aspectos institucionais introduzidos pela ditadura.

Além disso, o relator José Luiz Maia havia previsto, na primeira versão do anteprojeto, duas normas que tipicamente constam de regimento interno em relação à Comissão Mista de Orçamento: a) seus membros teriam mandatos equivalentes aos dos integrantes das mesas diretoras da Câmara dos Deputados e do Senado Federal (ou seja, quatro anos, sem possibilidade de reeleição); b) a Comissão Mista de Orçamento seria formada por várias subcomissões que representariam as comissões permanentes da Câmara e do Senado.

Nove emendas foram propostas para alterar o desenho da Comissão Mista de Orçamento previsto no primeiro anteprojeto do relator da subcomissão. Apenas duas dessas emendas foram acolhidas por José Luiz Maia, ambas versando sobre aspectos organizacionais da Comissão Mista de Orçamento e de autoria de Messias Góis (PFL$\mathrm{SE}$ ). As duas emendas de Góis retiravam os dispositivos sobre mandatos de membros da 
Comissão Mista de Orçamento e sobre a organização desta comissão em subcomissões, pois "tal como está, dificultaria qualquer modificação futura da comissão para atender a novas conjunturas". Esta preocupação de Góis foi ecoada por outros parlamentares. Victor Faccioni (PDS-RS) propôs emenda suprimindo parte do anteprojeto do relator que daria caráter permanente à CMO. Assim a justificou: "Tentamos retirar do anteprojeto original detalhes que nos parecem próprios de regimentos internos e que nem nesses devem estar por restringir prioridades, por outro lado, acrescentamos o reestabelecimento de prerrogativas do Legislativo". Sua emenda, no entanto, não foi acolhida. No mesmo sentido, Hélio Rosas (PMDB-SP), propôs a retirada da parte do anteprojeto do relator que dizia que a CMO seria constituída por subcomissões com representação das comissões técnicas permanentes do Senado e Câmara. A justificativa de Rosas: "Propõe-se essa nova redação para dar maior flexibilidade ao texto constitucional, permitindo que a composição e o mandato dos membros da Comissão Mista possam ser definidos pelo Regimento Comum do Congresso Nacional, que poderá mais facilmente alterá-lo, no sentido de seu aperfeiçoamento institucional". Sua emenda não foi acolhida formalmente, mas na prática sim.

Três emendas foram propostas para alterar o desenho da Comissão Mista de Orçamento previsto no primeiro anteprojeto do relator da subcomissão, que definia somente que as emendas teriam que ser compatíveis com o planejamento orçamentário e teriam que indicar fontes de financiamento. Os parlamentares Lídice da Mata (PC do B) e José Guedes (PMDB) propuseram a supressão do inciso do anteprojeto do relator que determinava a compatibilidade de emendas orçamentárias com os planos de médio e curto prazos. Essas duas emendas não foram acolhidas. Jairo Carneiro (PFL) propôs que as emendas deveriam ser proporcionais à população e inversas à renda, mantendo para elas a indicação das respectivas fontes de financiamento. Sua proposta tampouco foi incorporada pelo relator José Luiz Maia.

A versão final do anteprojeto da subcomissão alterou um ponto relevante sobre as emendas orçamentárias: elas não poderiam alterar a natureza econômica da despesa. Em outras palavras, uma emenda orçamentária que cortasse despesas com pessoal teria que necessariamente dispor sobre gastos com pessoal, não podendo, por exemplo, destinar recursos para determinado investimento público. Do mesmo modo, uma emenda orçamentária que cortasse despesas com investimentos teria que necessariamente prever novos investimentos, não podendo alocar os recursos para cobrir gastos com salários de funcionários da administração pública federal. 
Observa-se, portanto, que o relator acolheu poucas sugestões de seus pares, sendo as mais relevantes referentes às atribuições e organização da Comissão Mista de Orçamento. Essas mudanças não frustaram as expectativas do relator. Antes disso, é relevante analisar as idas e vindas do desenho orçamentário no projeto final da Comissão de Finanças, no projeto final da Comissão de Sistematização e, finalmente, na Constituição Federal promulgada em outubro de 1988.

Tabela 3.6: Escolhas da Assembléia Nacional Constituinte sobre processo orçamentário

\begin{tabular}{|c|c|c|c|}
\hline Assuntos & $\begin{array}{l}\text { Anteprojeto final da } \\
\text { Comissão do Sistema } \\
\text { Tributário, Orçamento } \\
\text { e Finanças }\end{array}$ & $\begin{array}{l}\text { Projeto final da } \\
\text { Comissão de } \\
\text { Sistematização }\end{array}$ & $\begin{array}{l}\text { Constituição Federal de } \\
1988\end{array}$ \\
\hline $\begin{array}{l}\text { Fiscalização } \\
\text { Orçamentária }\end{array}$ & $\begin{array}{l}\text { i) Diversos artigos } \\
\text { dispõem sobre } \\
\text { fiscalização e a } \\
\text { composição e } \\
\text { competências do TCU } \\
\text { ii) Fiscalização cabe ao } \\
\text { Congresso com auxílio } \\
\text { do TCU. }\end{array}$ & $\begin{array}{l}\text { i) Diversos artigos } \\
\text { dispõem sobre } \\
\text { fiscalização e a } \\
\text { composição e } \\
\text { competências do TCU; } \\
\text { ii) Fiscalização cabe à } \\
\text { CMO. }\end{array}$ & Igual ao anterior. \\
\hline $\begin{array}{l}\text { Conteúdo das } \\
\text { leis } \\
\text { orçamentárias: } \\
\text { PPA, LOA, } \\
\text { LDO }\end{array}$ & $\begin{array}{l}\text { i) orçamento unificado } \\
\text { ii) definições sobre o } \\
\text { PPA } \\
\text { iii) definição geral da } \\
\text { LOA, que deve ser } \\
\text { enviada ao Congresso } 4 \\
\text { meses antes do início do } \\
\text { ano fiscal } \\
\text { iv) execução } \\
\text { orçamentária } \\
\text { v) créditos } \\
\text { extraordinários }\end{array}$ & $\begin{array}{l}\text { i) orçamento unificado } \\
\text { ii) definições sobre o } \\
\text { PPA, LDO e LOA } \\
\text { iii) Prazo para envio de } \\
\text { LOA será determinado } \\
\text { por lei complementar } \\
\text { iv) execução } \\
\text { orçamentária } \\
\text { v) créditos } \\
\text { extraordinários }\end{array}$ & $\begin{array}{l}\text { Igual ao anterior, exceto } \\
\text { o item iv, que não consta. }\end{array}$ \\
\hline $\begin{array}{l}\text { Normatização } \\
\text { das finanças } \\
\text { públicas }\end{array}$ & $\begin{array}{l}\text { Lei Complementar de } \\
\text { Finanças Públicas - sem } \\
\text { prazo definido - irá } \\
\text { regular diversos aspectos } \\
\text { do Orçamento da União }\end{array}$ & Igual. & Igual. \\
\hline $\begin{array}{l}\text { Vinculação de } \\
\text { receitas }\end{array}$ & $\begin{array}{l}\text { Vinculação é vedada, } \\
\text { salvo as previstas no } \\
\text { capítulo do Sistema } \\
\text { Tributário Nacional. }\end{array}$ & $\begin{array}{l}\text { Vinculação é vedada, } \\
\text { exceto para (a) } \\
\text { educação, (b) impostos } \\
\text { a que se referem arts. } \\
187 \text { e } 188 ; \text { (c) garantias } \\
\text { para operações que } \\
\text { antecipam receitas } \\
\text { orçamentárias }\end{array}$ & $\begin{array}{l}\text { Vinculação é vedada, } \\
\text { exceto para (a) educação, } \\
\text { (b) impostos a que se } \\
\text { referem arts. } 187 \text { e } 188 ; \\
\text { (c) garantias para } \\
\text { operações que antecipam } \\
\text { receitas orçamentárias }\end{array}$ \\
\hline $\begin{array}{l}\text { Regionalização } \\
\text { dos gastos }\end{array}$ & $\begin{array}{l}\text { Lei Complementar que } \\
\text { tratará do PPA deverá } \\
\text { observar "a } \\
\text { regionalização do plano, } \\
\text { quando couber, levando } \\
\text { em conta as necessidades }\end{array}$ & $\begin{array}{l}\text { PPA considerará a } \\
\text { regionalização dos } \\
\text { gastos }\end{array}$ & $\begin{array}{l}\text { i) PPA estabelecerá, de } \\
\text { forma regionalizada, } \\
\text { diretrizes e objetivos para } \\
\text { despesas } \\
\text { ii) Orçamentos devem } \\
\text { reduzir desigualdades }\end{array}$ \\
\hline
\end{tabular}




\begin{tabular}{|c|c|c|c|}
\hline & $\begin{array}{l}\text { e peculiaridades das } \\
\text { diferentes regiões do } \\
\text { país" }\end{array}$ & & $\begin{array}{l}\text { inter-regionais segundo } \\
\text { critério populacional }\end{array}$ \\
\hline $\begin{array}{l}\text { Comissão } \\
\text { Mista de } \\
\text { Orçamento }\end{array}$ & $\begin{array}{l}\text { i) Cabe à CMO analisar } \\
\text { orçamentos propostos } \\
\text { pelo Executivo. } \\
\text { ii) Emendas } \\
\text { orçamentárias serão } \\
\text { oferecidas somente na } \\
\text { CMO, que terá poder } \\
\text { conclusivo e final sobre } \\
\text { elas, salvo manifestação } \\
\text { de } 1 / 3 \text { do plenário de } \\
\text { cada uma das casas para } \\
\text { rever o parecer da CMO } \\
\text { sobre emendas }\end{array}$ & $\begin{array}{l}\text { i) Cabe à CMO analisar } \\
\text { orçamentos propostos } \\
\text { pelo Executivo e } \\
\text { realizar a fiscalização } \\
\text { financeira. } \\
\text { ii) Não há menção a } \\
\text { poder conclusivo da } \\
\text { CMO sobre emendas. }\end{array}$ & Igual ao anterior. \\
\hline $\begin{array}{l}\text { Emendas } \\
\text { orçamentárias }\end{array}$ & $\begin{array}{l}\text { i) Emenda para aumentar } \\
\text { despesa só será } \\
\text { deliberada se: (a) for } \\
\text { compatível com PPA e } \\
\text { LDO; (b) indicar } \\
\text { recursos advindos de } \\
\text { operações de créditos ou } \\
\text { mudança na legislação } \\
\text { tributária. } \\
\text { ii) Emenda não pode: (a) } \\
\text { alterar natureza } \\
\text { econômica da despesa; } \\
\text { (b) indicar excesso de } \\
\text { arrecadação como fonte } \\
\text { de recurso. }\end{array}$ & $\begin{array}{l}\text { i) Emendas serão } \\
\text { apresentadas à CMO e } \\
\text { apreciadas, na forma } \\
\text { regimental, pelo } \\
\text { Congresso } \\
\text { ii) Emendas podem ser } \\
\text { propostas apenas para } \\
\text { investimentos } \\
\text { iii) Emendas (a) não } \\
\text { podem ser } \\
\text { incompatíveis com } \\
\text { PPA e LDO; (b) devem } \\
\text { prever recursos a partir } \\
\text { de despesas anuladas } \\
\text { iv) Emendas a créditos } \\
\text { suplementares também } \\
\text { são aceitas }\end{array}$ & $\begin{array}{l}\text { i) Emendas serão } \\
\text { apresentadas à CMO e } \\
\text { apreciadas pelo plenário } \\
\text { do Congresso } \\
\text { ii) Emendas (a) não } \\
\text { podem ser incompatíveis } \\
\text { com PPA e LDO; (b) } \\
\text { devem prever recursos a } \\
\text { partir de despesas } \\
\text { anuladas } \\
\text { iii) Emendas não podem } \\
\text { prever anulação de } \\
\text { despesas (a) com pessoal; } \\
\text { (b) com serviço da } \\
\text { dívida; (c) com } \\
\text { transferências } \\
\text { constitucionais para } \\
\text { estados e municípios }\end{array}$ \\
\hline $\begin{array}{l}\text { Limite de } \\
\text { gastos com } \\
\text { pessoal }\end{array}$ & $\begin{array}{l}\text { Não pode exceder } 65 \% \\
\text { dos gastos correntes. }\end{array}$ & $\begin{array}{l}\text { Limite será } \\
\text { estabelecido em lei } \\
\text { complementar }\end{array}$ & Igual ao anterior \\
\hline
\end{tabular}

Observa-se na tabela 3.6 acima que alterações extremamente relevantes ao projeto da subcomissão prosperaram nas fases subseqüentes da Assembléia Nacional Constituinte. Não cabe aqui analisar uma a uma, mas sim frisar as mudanças em relação aos dois assuntos que mais interessam ao texto: emendas orçamentárias e Comissão Mista de Orçamento. Em relação à Comissão Mista de Orçamento, o relator José Serra (PMDBSP) manteve a proposta final da subcomissão de fornecer a esta comissão o parecer conclusivo sobre emendas, salvo manifestação contrária de um terço dos parlamentares. Essa medida caiu nas fases seguintes, com a Constituição finalmente remetendo o assunto para o Regimento Interno. 
Quanto às emendas orçamentárias, a Comissão de Sistematização impôs restrição não prevista por José Luiz Maia nem por José Serra. Emendas só poderiam ser propostas para a parte do orçamento destinada a investimentos. A Constituição manteve isso com outra redação, disciplinando que as emendas não podem prever anulação de despesas (a) com pessoal; (b) com serviço da dívida; (c) com transferências constitucionais para estados e municípios. Cabe frisar, no entanto, que a prerrogativa dos parlamentares de emendar o orçamento não foi combatida em nenhuma instância da Constituinte. A decisão final sobre esse assunto assemelha-se enormemente à opinião do ex-ministro da Fazenda, Mario Henrique Simonsen, sobre o assunto. Convocado em reunião conjunta da Comissão de Finanças e da Subcomissão de Orçamento e Fiscalização Financeira, realizada em 30/4/1987, Simonsen assim se pronunciou sobre a prerrogativa de os parlamentares emendarem o orçamento: "No que tange à capacidade de o Congresso remanejar verbas e criar novas despesas durante a apreciação da lei orçamentária, minha impressão é a de que se deveria ficar em um meio-termo entre a Constituição Federal de 1946 e a de 1967. A de 1967, certamente, amarrou demais o Legislativo. Em compensação, a Constituição de 1946 permitia que se fizesse algo que não é desejável globalmente, ou seja, criar despesa sem indicar a fonte de financiamento. A meu ver, se se estabelecesse algo parecido, por exemplo, com o que existe na Constituição alemã, segundo a qual qualquer congressista pode propor despesa, desde que indique a correspondente fonte de receita. Já seria uma melhoria em relação à Constituição de 1967 e um freio contra o excesso de déficit público".

Quem, afinal, saiu ganhando? O relator da subcomissão ou o relator da comissão? Os dados indicam que as preferências de ambos sobre diversos assuntos orçamentários foram derrubadas em etapas posteriores da Assembléia Nacional Constituinte $^{72}$. Não se sabe a opinião de José Luiz Maia, mas José Serra assim se manifestou sobre seu trabalho: "Eu fui relator dos capítulos do sistema financeiro, orçamentário e tributário. O capítulo orçamentário absorveu talvez $95 \%$ das minhas idéias. Ele é enxuto e contribuiu muito para uma ordenação do gasto público no Brasil. O capítulo tributário, eu diria, ficou com $60 \%$ do que eu pensava. Foi intensamente negociado, o tempo inteiro. Eu tinha consciência, em certos momentos, de que estavam

\footnotetext{
72 Isso contraria a visão de Afonso (s/d, p. 7), segundo quem “a constância de princípios, conteúdo e forma das normas dos projetos decorre do fato de que foram poucos e sempre os mesmos 'atores' ou participantes dos debates sobre [finanças públicas] na Assembléia Nacional Constituinte. É peculiar o fato de que, ao contrário da maioria das matérias, não sobressaíram nessas discussões posições ideológicas e político-partidárias".
} 
entrando coisas no capítulo com as quais eu não estava de acordo mas que seria pior se eu não fosse o relator. E o capítulo do sistema financeiro foi puramente defensivo com relação às tendências absurdas que havia dentro do Congresso" (Serra 2002, p. 181).

É importante destacar ainda alguns pontos. Assuntos menos salientes, a julgar pelo número de emendas ao anteprojeto propostas pelos demais parlamentares, foram os mais modificados. No entanto, modificações não alteraram o fato de emendas orçamentárias serem bastante permissivas, semelhantes ao do período 1946-1964, e a Comissão Mista de Orçamento manteve amplas prerrogativas e forte autonomia em relação ao plenário.

Para concluir, vale notar que a análise da critical juncture constituinte tem claríssima importância para a definição das prerrogativas de emendamento orçamentário (tratadas no capítulo 4) e a organização da Comissão Mista de Orçamento (tratada no capítulo 5) nos últimos vinte anos. A Constituição de 1988 estabeleceu o status quo inicial a partir do qual os atores políticos usaram e redefiniram as instituições orçamentárias brasileiras, por vezes de modo bastante distinto do imaginado pela maioria dos constituintes. O modo como um parlamentar na posição de agenda-setter conseguiu impor boa parte de suas preferências sobre um tema de baixa saliência - ou seja, o relator José Luiz Maia e as instituições orçamentárias durante a Constituinte - é ecoado, como veremos no quinto capítulo, pelo exemplo do entrepreneur Ricardo Barros e suas preferências sobre descentralização orçamentária. 


\section{Capítulo 4}

\section{Layering institucional: prerrogativas de emendamento orçamentário}

A prerrogativa parlamentar de emendar o orçamento proposto pelo Executivo foi um dos principais ganhos da Constituição Federal de 1988. Como o terceiro capítulo mostrou, a volta da capacidade de emendar não foi combatida por qualquer grupo politico em nenhuma etapa do processo constituinte de 1987-1988. Desde então, parlamentares propõem emendas individuais e coletivas ao orçamento e, acreditam, são reeleitos em parte por causa desta capacidade readquirida.

Este capítulo tem o objetivo de explicar dois paradoxos do emendamento orçamentário no Brasil. O primeiro é: por que emendas propostas individualmente por parlamentares convivem com emendas orçamentárias coletivas, que podem ser propostas por comissões parlamentares ou bancadas estaduais? Afinal, se os parlamentares crêem que o principal propósito das emendas é auxiliá-los a atender pontualmente suas bases eleitorais (geográficas, setoriais ou de outra natureza), não haveria motivo para torná-las coletivas.

O segundo paradoxo é a progressiva limitação de alguns aspectos relativos ao emendamento - como o número de emendas individuais a serem propostas e a natureza das emendas coletivas, entre outros. À primeira vista, não faz sentido que parlamentares imponham limites a qualquer aspecto do emendamento individual, já que acreditam se beneficiar dele. Faz sentido que muitas limitações sejam impostas ao emendamento coletivo, que pode ser entendido como benéfico para a oposição. Neste caso, o paradoxo se refere à própria existência de emendas coletivas.

Esses paradoxos - a convivência de emendas individuais com coletivas e as limitações a ambos os tipos de emendamento - compõem um processo de mudança institucional chamado por Mahoney e Thelen (2009) de layering institucional.

Argumento que ambos os paradoxos podem ser explicados através de uma abordagem analítica que considera a interação entre idéias e interesses - tanto de curto prazo quanto de longo prazo - durante critical junctures. Conforme o primeiro capítulo mostra, sigo a definição de Campbell (2004, p. 93) para idéias. Para este autor, idéias podem ser tanto suposições profundas, que orientam o background do debate político, 
quanto as alternativas referentes a políticas públicas ou instituições mobilizadas diretamente pela elite política no foreground do debate. Enfatizo a segunda definição, observando que a primeira pode ser facilmente associada a definições correntes de ideologia ${ }^{73}$.

Essas idéias, que podem ser tanto discursos quanto projetos parlamentares (ou emendas a projetos), circulam mais livremente durante critical junctures. Capoccia e Kelemen (2007, p. 348) definem critical junctures como "períodos de tempo relativamente curtos, durante os quais há uma probabilidade significativamente maior de que as escolhas dos atores afetarão o resultado político que interessa estudar”. Há razoável consenso entre analistas que critical junctures são períodos nos quais idéias e propostas circulam mais livremente, permintindo que atores "experimentem, testem e explorem diversas alternativas" (Katznelson 2003, p. 282) ${ }^{74}$. As critical junctures permitem também a mobilização de muitos tipos de enquadramentos discursivos, que permitem distinguir interesses de curto e longo prazo dos atores políticos, como veremos mais adiante.

Um dos argumentos principais deste capítulo é que as idéias dos parlamentares a respeito das prerrogativas de emendamento podem ser consoantes ou não com os interesses desses atores politicos. Seguindo Schickler (2001, p. 5), cinco tipos de interesses dos parlamentares motivam o desenho de instituições legislativas. Três têm especial relevância neste capítulo. São eles: i) interesse na reeleição; ii) interesses relativos ao pertencimento à coalizão ou oposição e iii) interesse no Legislativo como ator coletivo $^{75}$.

Os dois primeiros são de curto prazo, enquanto o terceiro se refere a efeitos de longo prazo. O fortalecimento do Legislativo como ator coletivo é algo que ocorre apenas após diversas decisões que, acumuladas, atendem a esse interesse, enquanto decisões institucionais que atendem aos outros interesses citados não necessitam se acumular para que seus efeitos sejam atingidos.

As idéias dos parlamentares, no entanto, podem também ser contrárias a seus interesses de curto prazo, configurando o que chamo de "preferências deslocadas" dos atores. Trata-se, por exemplo, de um ator que tem interesses A e B para apoiar a

\footnotetext{
${ }^{73}$ Esta discussão está aprofundada no primeiro capítulo.

${ }^{74}$ Trata-se de momentos parecidos com o que Kingdon (1995, p. 194-5) denomina policy windows, abertas com a "aparição de problemas urgentes ou acontecimentos repentinos no meio político". Podem ser úteis para oxigenar a circulação de idéias, abrindo espaço para que propostas heterodoxas circulem.

${ }^{75}$ Os outros interesses são referentes ao acesso a postos de poder institucional e a políticas públicas.
} 
instituição $\mathrm{X}$ (os interesses podem ser pela reeleição e pertencimento à coalizão; a instituição pode ser "emendas individuais ilimitadas"), mas defende o fim (ou limitação parcial) desta instituição.

O conceito de "preferências deslocadas" é especialmente importante para entender três fenômenos. O primeiro é avaliar quão "crítica" é certa critical juncture, contribuindo para a análise de Cappocia e Kelemen (2007) sobre como definir períodos temporais como critical junctures. Esses autores propõem dois critérios para analisar a dimensão crítica das CJs: o "pulo da probabilidade" e a "relevância temporal". As critical junctures aqui consideradas - de 1994-1995 e 2005-2006 - são avaliadas de acordo com esses critérios no segundo capítulo. Quanto mais "preferências deslocadas" houver, mais "crítica" será certa critical juncture.

O segundo fenômeno que as "preferências deslocadas" ajudam a entender é a interação entre interesses de curto e longo prazo em critical junctures. Para justificar suas "preferências deslocadas", os parlamentares tendem a utilizar enquadramentos discursivos que privilegiam interesses de longo prazo e mascaram certos interesses de curto prazo. No caso deste capítulo, os escândalos de corrupção orçamentária em 19931994 podem permitir que um ator utilize o enquadramento "corrupção" para defender, por exemplo, o fim das emendas individuais - algo que seria contrário a seu interesse pela reeleição.

Por fim, o terceiro fenômeno que as "preferências deslocadas" ajudam a analisar é a importância do entrepreneur em certa critical juncture. Não é arriscado afirmar que os entrepreneurs são especialmente susceptíveis a propor idéias orientadas por "preferências deslocadas", pois se comprometem a "investir recursos" (Sheingate 2003, p. 188) em torno de certas idéias muito mais do que um ator "normal" faz. Esse investimento "exagerado" de recursos - que podem ser a introdução de um projeto de lei, discursos recorrentes em torno de uma idéia específica etc. - permite que o entrepreneur defenda idéias contrárias aos interesses do grupo politico a que pertence. Ou permite, mais realisticamente, que o entrepreneur defenda, dentro de um conjunto de idéias, algumas delas contrárias a seus interesses ("preferências deslocadas") e outras idéias consoantes com seus interesses. Isso faz sentido também se pensarmos que um entrepreneur tipicamente terá que negociar uma parte do que quer para que seu projeto seja aprovado. Desse modo, os entrepreneurs podem influenciar enormemente a agenda política de uma critical juncture. Se há um grupo favorável e outro contrário à idéia $\mathrm{X}$, o apoio de um entrepreneur a esta idéia- sendo que o normal a esperar deste 
entrepreneur seria uma posição desfavorável a ela - pode ser crítico para que esta idéia $\mathrm{X}$ prospere.

Este raciocínio nos lembra que as idéias - informadas por "preferências deslocadas" ou não -inserem-se em um contexto cuja agenda é controlada por um grupo politico. No caso deste trabalho, simplifico e assumo que dois grupos disputam esse controle: a coalizão liderada pelo Executivo e a oposição. Nas duas critical junctures aqui analisadas, a coalizão obteve amplo controle da agenda durante a primeira (19941995) e dividiu, com um entrepreneur da oposição, Ricardo Barros, o controle da agenda durante a segunda critical juncture (2005-2006).

Quais são as idéias orientadas por "preferências deslocadas" neste capítulo? São: I) qualquer parlamentar defendendo limite de número, valor e natureza de emendas individuais, pois a reeleição interessa a todos, ainda que os parlamentares da coalizão sejam mais beneficiados do que os da oposição na execução das emendas individuais, conforme mostrei no primeiro capítulo e II) parlamentares da oposição defendendo limites ao emendamento coletivo, pois podem acreditar que se beneficiarão deste tipo de emendamento já que o emendamento invididual beneficia mais os parlamentares da coalizão. A critical juncture de 1994-1995 viu os itens I e II acontecerem, enquanto em 2005-2006 ocorreu apenas o segundo item.

Vale relembrar o argumento, já exposto no segundo capítulo, que orienta esta discussão. Interessaria fortemente à coalizão governista dentro do Legislativo estabelecer certos limites às emendas, mesmo considerando que o Executivo controla a execução orçamentária e pode simplesmente não executar as emendas. Ainda asism, o Executivo pode ganhar se não tiver que negociar emendas, e a coalizão representa os interesses do Executivo. Portanto, podemos esperar que os parlamentares da coalizão sejam favoráveis a propostas no sentido de limitar as prerrogativas de emendar o orçamento. Este interesse deve ser forte sobretudo em relação às emendas coletivas, pois trata-se de um espaço institucional que pode ser aproveitado por parlamentares da oposição para compensar a baixa execução de emendas individuais. Não interessaria aos parlamentares da oposição estabelecer limites às emendas, pois perderiam espaço para barganhar a liberação de ao menos parte de suas emendas com o Executivo. Além disso, se as emendas coletivas fossem limitadas, a oposição perderia outra venue para negociar 
seus interesses orçamentários. Podemos esperar que os parlamentares da oposição se oponham, fortemente, a propostas no sentido de limitar o emendamento orçamentário ${ }^{76}$.

A partir desta introdução, proponho que as idéias orientadas por "preferências deslocadas" têm mais chances de sucesso: i) quanto mais elas puderem ser associadas, através de enquadramentos, aos escândalos de corrupção que perfazem o background das CJs descritas nesta tese. Isto pode ser avaliado do seguinte modo: se o relatório de uma CPI que investiga corrupção orçamentária propõe a idéia $X$, é porque esta idéia está associada ao escândalo; e ii) quanto maior for a capacidade de persuasão dos entrepreneurs, medida com base na influência deles no controle da agenda, nos recursos que investiram e nos enquadramentos estratégicos que utilizaram para convencer os atores.

Além disso, conforme afirmei no segundo capítulo, as idéias orientadas por "preferências deslocadas" serão mais bem-sucedidas quanto mais susceptível à pressão pública em torno do escândalo de corrupção está o grupo político que controla a agenda durante a critical juncture. Em 1995, a coalizão que controlou a agenda estava bastante sensível ao escândalo dos "anões do orçamento", dado o fato de parlamentares com cargos relevantes, como os presidentes da Câmara e do Senado, estarem envolvidos e a relevância do controle do processo orçamentário para o novo presidente Fernando Henrique Cardoso; em 2006, o escândalo dos "sanguessugas" pressionou menos os parlamentares que controlavam a agenda, pois a coalizão já controlava o processo orçamentário satisfatoriamente e nenhum parlamentar com cargo muito importante estava envolvido.

A próxima seção avalia, caso a caso, por que: os parlamentares brasileiros optaram, ao longo desses anos, pela limitação ao número de emendas individuais; por limitar parcialmente a natureza das emendas individuais; por ampliar os atores que podem propor emendas coletivas; por não limitar o valor global das emendas coletivas e, por fim, por limitar enormemente a natureza das emendas coletivas.

Catorze decisões foram tomadas sobre esses pontos nas critical junctures de 1994-1995 e 2005-2006, sete em cada CJ. Oito delas são "paradoxais", ou seja, a teoria de interesses da escolha racional não conseguiria explicá-las razoavelmente. Trata-se de

\footnotetext{
${ }^{76}$ Este argumento ignora o fato de haver parlamentares completamente indiferentes ao processo orçamentário e que, mesmo sendo da coalizão, não procurarão limitar emendas de nenhuma maneira. Ignora também que pode haver parlamentares da coalizão insatisfeitos com a execução de suas emendas individuais que procurarão satisfazer suas preferências orçamentárias através de emendas coletivas. $\mathrm{O}$ argumento explica, no entanto, os interesses médios dos parlamentares da coalizão e oposição em relação ao emendamento orçamentário.
} 
decisões contra os interesses de curto prazo (relativos à reeleição e relativos ao pertencimento à coalizão/oposição) do grupo que controlou a agenda nas critical junctures $^{77}$.

Na próxima seção, veremos como as idéias sobre os cinco pontos relativos a emendamento orçamentário circularam antes, depois e durante cada critical juncture. Isto é importante para mostrar como os escândalos de corrupção desvendados em 1994 e 2006 influenciaram a agenda de idéias. Analiso também os enquadramentos discursivos mobilizados pelos atores politicos e a freqüência de idéias orientadas por "preferências deslocadas", com o objetivo de verificar como o controle da agenda nas critical junctures ocorreu na prática, resultando ou não em medidas substantivas favoráveis ao grupo politico que controlou a agenda.

\section{(1) Cinco aspectos do emendamento orçamentário}

\section{1) Número de emendas individuais}

Emendas individuais são compreendidas pelos parlamentares como mecanismos de atendimento às "bases eleitorais" que melhoram suas chances de reeleição. São uma parte importante da complexa estratégia eleitoral de deputados brasileiros, que disputam 513 vagas em um sistema de representação proporcional no qual o distrito eleitoral é o estado. Além dos estados e da União, os municípios também são entes federativos definidos constitucionalmente, algo que lhes confere ampla autonomia administrativa e, em cerca de $19 \%$ deles, autonomia financeira ${ }^{78}$. A relação entre deputados federais, deputados estaduais e prefeitos dos municípios é um dos pilares das eleições brasileiras.

As emendas individuais propostas por parlamentares são parte importantíssima desta relação. Dois discursos de parlamentares em 2005 são exemplares para ilustrar isso. Cláudio Cajado, do PFL (oposição), reclamou: "É importante termos algum

\footnotetext{
${ }^{77}$ Houve cinco decisões paradoxais em 1995, referentes à natureza de emendas individuais, aos atores que podem propor emendas coletivas de bancada estadual e o número destas, aos atores que podem propor emendas coletivas de comissão e o número destas, e à natureza tanto das emendas coletivas de bancada estadual quanto das emendas coletivas de comissão. Em 2006, houve três decisões paradoxais, referentes ao número de emendas individuais, à natureza de emendas individuais e à natureza das emendas coletivas de bancada estadual.

${ }^{78}$ Em $81 \%$ dos mais de 5 mil municípios brasileiros, o fundo de participação dos municípios (FPM) é a principal fonte de receita. Composto por $22.5 \%$ do que a União arrecada com o Imposto de Renda e o Imposto sobre Produtos Industrializados, o FPM é uma transferência direta do governo federal para os municípios.
} 
mecanismo que permita que as emendas individuais apresentadas e aprovadas efetivamente sejam liberadas. Há dois anos minhas emendas não são liberadas. A pobre cidade de Dias D’Ávila, onde minha esposa é prefeita, está sofrendo agruras enormes. Faço minha função como deputado, apresento as emendas, divulgo-as e o povo fica a me cobrar. O contingenciamento feito pelo Executivo fulmina nossas expectativas" (Comissão 2005, 20/4/2005, p. 59). Wilson Santiago, do PMDB (coalizão), ecoou suas preocupações: “A bancada de nosso estado tem dezoito deputados e senadores, além dos governadores e prefeitos das capitais, defendendo-as e pressionando o governo, e mesmo assim não estamos conseguindo liberar 50\% dessas emendas. Imaginem bem se reduzirmos ainda mais o número de interessados" (Comissão 2005, 31/5/2005, p. 273). Os prefeitos estão tão interessados em participar do processo de emendamento que o Congresso publica periodicamente um "manual de orientação" para explicar a eles os caminhos possíveis para obter recursos federais para seus municípios (Bezerra 1999, p. 144).

Este raciocínio serve para mostrar como o sistema político brasileiro depende, de certo modo, da existência de mecanismos que levam pork aos municípios e aos estados. Acabar com qualquer mecanismo desse tipo não é tarefa fácil, dada a pletora de atores que com eles têm vantagens.

Tanto a Comissão Parlamentar de Inquérito que investigou os "anões do orçamento" em 1993-1994 quanto a CPI das Ambulâncias em 2006 recomendaram o fim das emendas individuais. A ligação destas com esquemas de corrupção é claríssima. O relatório da CPI mais recente afirmou: "É preciso esclarecer que o esquema da Planam $^{79}$ utilizou-se de transferências de recursos a municípios à conta de autorizações orçamentárias, tendo como origem emendas individuais, emendas coletivas ou mesmo a

\footnotetext{
${ }^{79}$ Um resumo sucinto do esquema de corrupção é: “A quadrilha que fraudava a venda de ambulâncias para prefeituras de diversos estados era chefiada pela família Trevisan Vedoin, no Mato Grosso, e tinha membros infiltrados na Câmara dos Deputados, no Ministério da Saúde e na Associação de Municípios do Mato Grosso. O primeiro passo da ação da quadrilha era o contato com os prefeitos interessados. $\mathrm{O}$ responsável pelo contato seria José Wagner dos Santos. Nessa conversa com os prefeitos, ele dizia que poderia entregar uma ambulância completa antes de o prefeito consegui-la pelos trâmites normais. Com a concordância do prefeito, a quadrilha acionava assessores de parlamentares que preparavam emendas a serem apresentadas. O texto era aprovado no Congresso Nacional e a assessora do Ministério da Saúde, Maria da Penha Lino, teria a incumbência de aprovar o convênio e facilitar a liberação do recurso. Caberia à empresa Planam, de propriedade da família Trevisan Vedoin, montar as ambulâncias e entregálas ao prefeito. A empresa superfaturava em até $110 \%$ a operação e entregava um veículo sem os equipamentos necessários para atendimentos de emergência. No total, a quadrilha teria movimentado R\$ 110 milhões desde 2001 e entregue 1.000 veículos. Cada intermediário recebia propina para atuar. Há indícios, conforme as investigações, que dois ex-parlamentares, Ronivon Santiago e Carlos Rodrigues, tenham também recebido propina" ("Entenda o esquema de compra irregular de ambulâncias", Folha Online, 10/8/2006).
} 
programação não derivada de emendas. (...) A emenda individual, da forma como hoje se apresenta, pode e é utilizada como instrumento de tráfico de influência e barganha política" ${ }^{\circ 0}$.

Parlamentares de coalizão e oposição protestaram contra esta recomendação das CPIs. Utilizaram abundamentemente o enquadramento discursivo referente à representação, com dois exemplos a seguir. O primeiro é a afirmação de Nelson Marquezelli, do PTB, para quem "o parlamentar deve ter liberdade para lutar pelos interesses de sua região" (Emenda ao Projeto José Fogaça, 30/8/1995). Sérgio Guerra, do PSDB, alonga-se na defesa das emendas: "A emenda individual foi uma maneira de o estado federal brasileiro estar presente em centenas de municípios, bases esquecidas do país a que o governo federal não consegue chegar. Por outro lado, ela gerou um mecanismo de conveniente apropriação pública. Participei de várias campanhas municipais no Nordeste, nas quais era tema de discurso a avaliação de programas feitos com emenda individual de deputados federais e senadores - mais os primeiros. Alguns diziam que os recursos tinham vindo, mas a obra não tinha sido feita. Outros alegavam que os recursos tinham chegado, trazidos por determinado deputado, e a obra estaria pronta. Desse modo, a própria sociedade começou a desenvolver um trabalho de fiscalização e de avaliação dessas emendas" (Comissão 2005, 7/4/2005, p. 217-218) ${ }^{81}$.

$\mathrm{O}$ fato de tanto membros da coalizão quanto a oposição defenderem a existência de emendas individuais mostra que esta instituição é mais ligada ao interesse pela reeleição, compartilhado por todos os parlamentares, do que a outros tipos de interesse.

No entanto, respondendo à pressão da opinião pública relativa aos escândalos, diversos parlamentares apoiaram o fim das emendas individuais, incorrendo em "preferências deslocadas". Para isso, utilizaram enquadramentos referentes à corrupção (do mesmo modo que a CPI de 2006), barganha política e eficiência processual do Legislativo. Os discursos abaixo ilustram cada um desses argumentos. Eduardo Valverde, do PT (coalizão), afirmou: "Nosso papel deveria ser tão-somente de fiscalizar a aplicação do orçamento e discutir as linhas gerais de investimento, porque uma atuação pontual, através das emendas individuais, acaba deixando de dar rumo a uma

\footnotetext{
${ }^{80}$ Esta posição sobre as emendas individuais ganhou forte adesão da imprensa e representantes de organizações não-governamentais. Ver, por exemplo, "A corrupção migrou para a administração indireta: o deputado que preside a ONG Contas Abertas defende o fim das emendas parlamentares", por Octávio Costa e Adriana Nicácio, IstoÉ Dinheiro, 26/5/2007 e "Emendar as emendas", editorial da Folha de S. Paulo, 12/8/2006.

${ }^{81}$ A consultora de orçamento do Senado Federal Rita de Cássia Leal Fonseca dos Santos afirmou, em entrevista realizada em Maio/2008, que "as emendas individuais são a voz dos municípios no orçamento federal".
} 
percepção abrangente dos interesses nacionais. Temos vários exemplos de obras que foram indiciadas por irregularidade pelo Tribunal de Contas da União e o último escândalo que ocorreu nesta Casa, dos 'anões do orçamento"” (Comissão 2005, 20/4/2005, p. 77).

Luiza Erundina, do PSB, adiciona um argumento "anti-barganha" para defender a eliminação das emendas individuais: "Com a supressão das emendas individuais, busca-se eliminar uma das principais modalidades de relações obscuras entre parlamentares e interesses privados, bem como diferentes setores da administracao pública. Longe de se pretender ceifar a iniciativa e criatividade dos representantes do povo, espera-se, com essa modificação, valorizar o trabalho das comissões temáticas e arregimentar os esforços das bancadas estaduais em torno das prioridades de cada estado. (...) Outro benefício evidente desta modificação que ora propomos é a eliminacao da barganha que se estabelece sistematicamente entre o Executivo, que detém o controle da execução orçamentária, e o autor da emenda, quando se trata de descontingenciar as dotações e liberar os recursos das emendas já incluídas na lei em troca do apoio às proposições de iniciativa do Executivo. Isto constringe o parlamentar e reduz sua liberdade nas diversas formas de votação das propostas que tramitam" (Emenda ao Projeto Ricardo Barros, Maio/2006).

Finalmente, o entrepreneur Ricardo Barros, do PP (oposição), afirma que a eficiência do processo orçamentário seria aumentada caso fossem impostos limites ao número de emendas individuais a ser apresentado por cada parlamentar: "As votações são complexas, o relator-geral recebe cerca de 3 mil emendas e é obrigado a dar parecer para todas. Por isso, estamos tentando reduzir o número de emendas, até porque as bancadas podem se articular e distribuir entre seus membros a apresentação de emendas" (Comissão 2005, 5/4/2005, p. 172).

As "preferências deslocadas", auxiliadas pela publicização dos escândalos orçamentários, foram vitoriosas em todas as etapas cruciais. A Resolução 1/1993, que precedeu a CPI dos "anões do orçamento", fixou em cinqüenta o limite de emendas individuais por parlamentar. Este número diminuiu para vinte emendas na Resolução 2/1995, após forte pressão para que chegasse a dez ${ }^{82}$. Nas discussões de 2005, havia quem quissesse um aumento no número de emendas, mas isto foi brecado com a

\footnotetext{
${ }^{82}$ A primeira tabela do Anexo I detalha todos esses momentos.
} 
investigação em torno do escândalo dos sanguessugas em 2006. A Resolução 1/2006, por fim, limita a vinte e cinco emendas individuais por parlamentar.

\section{2) Natureza de Emendas Individuais}

Quais são os limites impostos à natureza de emendas individuais? A Constituição de 1988 elencou apenas três: i) a emenda tem que ser compatível com o Plano Plurianual e a Lei de Diretrizes Orçamentárias; ii) a emenda deve indicar os recursos necessários, admitidos apenas os que anulem despesas ${ }^{83}$ (excluídas as com transferências para municípios, estados e Distrito Federal; serviço da dívida; gastos com pessoal) e iii) a emenda pode utilizar recursos que resultam da identificação e correção de "erros ou omissões" do projeto orçamentário enviado pelo Executivo.

Trata-se de um cenário bastante permissivo e pouco alterado nos anos seguintes. A Resolução 1/1991 adicionou apenas que uma emenda "não pode ser constituída de várias partes que devam ser objeto de emendas distintas. A Resolução 2/1995 acrescentou ainda que os parlamentares poderiam indicar "erros e omissões" do Executivo também nas estimativas de receita e as emendas poderiam usar esses valores acrescentados pela reestimativa.

Ao analisar os parecer preliminares dos relatores-gerais do orçamento, é possível observer que havia alguma preocupação com a natureza das emendas individuais. Carlos Bezerra, relator-geral em 1996, observou que "os comitês de avaliação incumbidos de avaliar as emendas recomendaram que fossem rejeitadas as emendas individuais que propunham ação que extravasasse o âmbito municipal, que tivessem sido atendidas pelo relator setorial com montante insuficiente para concluir etapa ou a totalidade da obra, ou que preconizassem construção ou pavimentação de estradas federais" $" 84$.

Duas maneiras de subverter a natureza das emendas individuais parecem ser mais comuns: a emenda "guarda-chuva" e a "janela orçamentária". Ricardo Barros, do PP (oposição), define a primeira do seguinte modo: "A maioria dos parlamentares hoje faz emenda individual 'guarda-chuva', algo que as regras permitem. O parlamentar coloca valor de um milhão para unidades de saúde no Estado do Paraná e pode atender

\footnotetext{
${ }^{83}$ Ou seja, para efetuar o gasto $\mathrm{X}$ no projeto, a emenda deve prever a anulação do gasto X no projeto $\mathrm{B}$.

${ }^{84}$ Comissão Mista de Orçamento. Parecer Preliminar sobre o Projeto de Lei n. 8, 1996-CN, que estima a receita e fixa a despesa da União para o exercício financeiro de 1997. Relator-Geral: Carlos Bezerra. 10 de outubro de 1996.
} 
20 ou 30 municípios com essa emenda" (Comissão 2005, 7/4/2005, p. 216). Infelizmente, as evidências empíricas a respeito desse tipo de emenda são extremamente escasassas, apesar de alusões por assessores técnicos do Orçamento [ver, por exemplo, Sanches (2007, p. 64)].

Mais comuns são as "janelas orçamentárias”. Trata-se de dotações orçamentárias com "valores simbólicos ou irreais", a serem suplementados por créditos adicionais (Bittencourt 2008, p. 58-59). O raciocínio é o seguinte. Desde 1997, quando o relatorgeral começou a estabelecer um limite para o valor global das emendas individuais, alguns parlamentares optaram por incluir emendas que claramente seriam insuficientes para executar a ação indicada. O passo seguinte seria convencer o ministério responsável pela área a propor "créditos adicionais" para a emenda, de modo que houvesse condições materiais suficientes para realizar a ação proposta pela emenda. É fundamental frisar o caráter informal deste tipo de emenda. As emendas do tipo "guarda-chuva" e "janelas orçamentárias" subvertem a natureza das emendas individuais pois vão contra a idéia de o parlamentar usar a emenda como um instrument para realizar pequenas melhorias em municípios que ele acredita representar.

Cabe salientar aqui que os debates em torno da natureza de emendas individuais no periodo analisado se deram em torno dessas "janelas orçamentárias", especialmente na critical juncture de 2005-2006 por iniciativa do entrepreneur Ricardo Barros. Em seu projeto de resolução datado de julho de 2005, Barros propôs que as emendas só poderiam destinar recursos para entidades privadas sob quatro condições: i) respeitando a Lei de Diretrizes Orçamentárias; ii) limitando-se à programação específica definida pelo relator-geral em seu parecer preliminar; iii) identificando a entidade beneficiada e iv) estipulando as metas que a entidade deve cumprir, sendo essas compatíveis com o valor da emenda (grifo meu). Trata-se de tentar prevenir a inclusão de "janelas orçamentárias".

Por que um parlamentar proporia limitações à natureza das emendas individuais? A teoria de interesses da escolha racional, a partir da qual o deputado só agiria de acordo com seu interesses em se reeleger, pertencer à coalizão e/ou ter acesso a um posto de poder institucional, não fornece resposta para este caso. É, portanto, uma "preferência deslocada" de Ricardo Barros. Neste caso específico, foi provavelmente motivada tanto pela vontade de ser um entrepreneur de inovações nas regras 
orçamentárias quanto a de responder a escândalos de corrupção ${ }^{85}$. Vale ressaltar que o relatório da CPI das Ambulâncias, proposto em agosto de 2006, clama pelo "exame obrigatório da adequação dos valores propostos pelas emendas individuais, tendo presente os custos do empreendimento e as metas pretendidas, evitando janelas orçamentárias ou superdimensionamento da dotação".

O resultado final veio na Resolução 1/2006, que dispõe: "As emendas individuais que destinarem recursos a entidades privadas, deverão observar a programação passível de ser objeto de emendas, definida no Parecer Preliminar e estipular as metas que a entidade beneficiária deverá cumprir, demonstrando a sua compatibilidade com o valor da emenda" (Resolução 1/2006, Art. 50, inciso II, grifo meu). A limitação formal às "janelas orçamentárias" proposta por Ricardo Barros foi, enfim, aprovada, embora isso não signifique que esta prática deixou de existir, como mostra Bittencourt (2008).

Barros teve sucesso em fazer aprovar outra pequena proposta que consta de seu projeto de resolução. É um item que afirma que as "emendas, em seu conjunto, devem resultar em montante suficiente para que obra - ou etapa do cronograma da execução seja completada”. Foi adotado no inciso III do artigo 50 da Resolução 1/2006.

A importância de um entrepreneur é sublinhada pelo fato de que outras propostas relativas à natureza de emendas individuais avançadas pela CPI das Ambulâncias em 2006 não tiveram sucesso. Um exemplo é a proibição do nepotismo em transferência de recursos para entidades privadas. A CPI recomendou "proibir a destinação e liberação de recursos a entidades privadas em que membros de quaisquer dos poderes da União ou respectivos cônjuges, companheiros ou parentes em linha reta, colateral ou por afinidade, até o terceiro grau, sejam ou tenham sido nos últimos cinco anos proprietários, controladores, diretores ou empregados". No entanto, apenas uma versão bastante diluída desta idéia foi aprovada na Resolução 1/2006, exigindo que a "emenda para entidade privada identifique a entidade beneficiada, seu endereço e o nome dos responsáveis pela direção"86. A descoberta de casos nepotismo depende, assim, de órgãos de controle da administração federal e jornalismo investigativo.

\footnotetext{
${ }^{85}$ Sérgio Guerra, do PSDB, também incorreu em "preferência deslocada" ao afirmar que "“"as emendas devem ser consistentes do ponto de vista macroeconômico. Quanto mais as identificarmos com políticas públicas gerais, melhores elas serão" (Comissão 2005, 7/4/2005, p. 218). Não propôs, no entanto, nenhuma medida concreta nesse sentido.

${ }^{86}$ Esta idéia foi proposta por José Carlos Aleluia em seu substitutivo ao projeto de Ricardo Barros em maio de 2006. Ver a segunda tabela do Anexo I.
} 
Outro exemplo de como limitações à natureza de emendas individuais são dificultadas na ausência de um entrepreneur foi a tentativa do relator-geral da Comissão Mista de Orçamento em 2006, Valdir Raupp, de permitir que parlamentares fizessem emendas para novas obras em municípios apenas a partir de R 150 mil. Com o valor abaixo de R\$ 150 mil, os prefeitos não são obrigados a fazer leilões públicos para as licitações e podem enviar carta-convite. Foi por meio de carta-convite que a quadrilha dos sanguessugas conseguia fraudar as licitações para a compra de ambulâncias superfaturadas. Os parlamentares rejeitaram a proposta de Raupp ${ }^{87}$.

Portanto, mesmo propostas de limitação à natureza de emendas individuais extremamente ligadas à corrupção não prosperaram sem um entrepreneur.

\section{3) Emendas Coletivas: número e atores}

Uma vez que as emendas individuais foram progressivamente limitadas, como vimos acima, os parlamentares optaram por criar emendas coletivas. A primeira medida veio na Resolução 1/1993, pouco antes do início da CPI que investigou os "anões do orçamento". As comissões permanentes do Senado Federal e Câmara dos Deputados podiam propor até 3 emendas cada, desde que sobre matérias pertinentes regimentalmente; partidos politicos podiam propor até 10 emendas, assinadas pela maioria absoluta da bancada; e bancadas estaduais podiam propor três emendas por parlamentar da bancada, cada uma delas subscritas por outros quatro parlamentares.

A Resolução 2/1995 manteve essas prerrogativas com poucas modificações, destacando a extinção das emendas de partidos politicos e a introdução de emendas de bancadas regionais, que poderiam apresentar até 5 emendas por região, deliberadas pela maioria da bancada, sendo que cada estado estaria representado por no mínimo $20 \%$ da bancada. Esse tipo de emenda foi sugerido por assessores técnicos da Câmara dos Deputados e Senado Federal, como mostra a tabela 3 do anexo I a este capítulo.

As emendas coletivas têm sido bastante usadas pelos parlamentares - e executadas pelo governo federal - desde 1993. Figueiredo e Limongi (2003, p. 69) notam que a distribuição percentual das emendas parlamentares em investimentos se deu da seguinte forma de 1996 a 2001: bancadas estaduais (50,7\%), parlamentares $(18,1 \%)$, relatores setoriais da Comissão Mista de Orçamento (10,3\%), relator-geral da

\footnotetext{
87 "Acordo derruba medidas que evitariam desvios no orçamento", Ana Paula Ribeiro, Folha Online, $8 / 11 / 2006$
} 
CMO (9,8\%), comissões $(8,4 \%)$ e bancadas regionais $(2,8 \%)$. Há um crescente uso de emendas coletivas, mas não à expensa das emendas individuais, como mostra a tabela 4.1 abaixo. Como veremos mais adiantes, as emendas coletivas são utilizadas pelos parlamentares para compensar limitações de número e valor às individuais.

Tabela 4.1: Emendas Individuais e Coletivas - Quantidade Apresentada e Valor Aprovado, 1994-2007 ${ }^{88}$

\begin{tabular}{|l|l|l|l|l|l|l|}
\hline & $\begin{array}{l}\text { Individuais: } \\
\text { quantidade }\end{array}$ & $\begin{array}{l}\text { Individuais: } \\
\text { Valor em } \\
\text { R\$ milhões }\end{array}$ & $\begin{array}{l}\text { Bancada } \\
\text { Estadual: } \\
\text { Quantidade }\end{array}$ & $\begin{array}{l}\text { Bancada } \\
\text { Estadual: } \\
\text { Valor em R\$ } \\
\text { milhões }\end{array}$ & $\begin{array}{l}\text { Comissão: } \\
\text { Quantidade }\end{array}$ & $\begin{array}{l}\text { Comissão: } \\
\text { Valor em } \\
\text { R\$ milhões }\end{array}$ \\
\hline $\mathbf{1 9 9 4}$ & 23.216 & 4.082 & 429 & 1.193 & - & - \\
\hline $\mathbf{1 9 9 5}$ & 10.403 & 862 & 279 & 1.608 & 110 & 169 \\
\hline $\mathbf{1 9 9 6}$ & 10.348 & 845 & 271 & 1.574 & 108 & 274 \\
\hline $\mathbf{1 9 9 7}$ & 8.533 & 866 & 245 & 2.048 & 121 & 464 \\
\hline $\mathbf{1 9 9 8}$ & 7.572 & 866 & 272 & 2.323 & 120 & 600 \\
\hline $\mathbf{1 9 9 9}$ & 8.334 & 880 & 275 & 3.256 & 112 & 1.334 \\
\hline $\mathbf{2 0 0 0}$ & 8.478 & 1.178 & 408 & 4.311 & 125 & 1.470 \\
\hline $\mathbf{2 0 0 1}$ & 7.642 & 1.178 & 426 & 5.444 & 123 & 1.733 \\
\hline $\mathbf{2 0 0 2}$ & 6.904 & 1.185 & 427 & 6.047 & 133 & 1.769 \\
\hline $\mathbf{2 0 0 3}$ & 7.278 & 1.483 & 508 & 3.756 & 144 & 839 \\
\hline $\mathbf{2 0 0 4}$ & 7.600 & 2.076 & 508 & 6.139 & 150 & 1.620 \\
\hline $\mathbf{2 0 0 5}$ & 7.943 & 2.964 & 508 & 5.767 & 160 & 2.003 \\
\hline $\mathbf{2 0 0 6}$ & 8.151 & 3.533 & 508 & 8.665 & 153 & 2.997 \\
\hline $\mathbf{2 0 0 7}$ & 8.998 & 4.743 & 482 & 8.755 & 139 & 2.688 \\
\hline
\end{tabular}

Fonte: Tollini (2009, p. 12)

Quando presidente da Comissão Mista de Orçamento em 2005, Paulo Bernardo enviou ofício ao presidente do Senado Federal sugerindo uma pauta de reformas orçamentárias. Entre elas, o fim das emendas de bancadas estaduais e regionais e a redução no limite de emendas coletivas a serem apresentadas. Trata-se de uma posição coerente com seu status de pertencimento à coalizão - pois, repetindo o que já afirmei acima, a existência de emendas coletivas interessaria sobretudo a parlamentares fora da coalizão, já que suas emendas individuais são menos executadas do que seus pares pertencentes à coalizão presidencial.

Paulo Bernardo associou a existência de emendas de bancada à "apropriação individual" dos parlamentares, resultando em "rachadinhas" (emendas individuais travestidas de coletivas). Utilizou, assim, o enquadramento referente a corrupção para justificar sua idéia. Do mesmo modo, a CPI das Ambulâncias, em agosto de 2006, pediu o "fortalecimento das emendas coletivas".

\footnotetext{
${ }^{88} \mathrm{O}$ ano é aquele no qual as emendas foram aprovadas, não gastas. As emendas regionais foram omitidas por motivos de espaço.
} 
Em março de 2005, o entrepreneur de oposição Ricardo Barros propôs a redução no número de emendas coletivas e, em relação às emendas de comissão, afirmou que essas poderiam ser extintas; serem tratadas somente pelo relator-geral ou serem tratadas somente pelos relatores setoriais.

É um caso de "preferência deslocada", pois poderíamos esperar que um deputado da oposição fosse favorável ao maior número possível de emendas coletivas. No entanto, há evidências de que Barros associava um grande número de emendas coletivas a práticas corruptas. Em 2007, o deputado criticou a Resolução 1/2001 como contendo "verdadeiros retrocessos, entre eles o aumento do número de emendas coletivas acima do número de parlamentares de cada bancada" (Barros 2007, p. 11). Se há mais emendas do que parlamentares, pode-se aferir que cada parlamentar pode ficar "responsável" por ao menos uma, tornando desnecessário o acordo coletivo. A falta de acordo em torno disso na discussão do projeto de Ricardo Barros oriundo da Comissão de 2005 foi um dos principais pontos que inviabilizou a votação desse projeto à época ${ }^{89}$. A resolução 1/2006 contrariou este desejo de Barros, fixando em 20 o número máximo de emendas de bancada estadual. Este total é signficativamente maior do que a quantidade de parlamentares de várias bancadas.

Em relação às emendas de comissão, a vontade inicial de Ricardo Barros em extingui-las pode ser explicado por um uso absolutamente inesperado desse tipo de emenda. Trata-se do uso informal dessas emendas por ministérios. O discurso da deputada Laura Carneiro, do PFL, é esclarecedor: "As emendas de comissão tradicionalmente se coadunam com o interesse do Executivo nas áreas afetas às comissões permanentes. (...) Nesse sentido, ao reduzir o número de emendas destinadas às comissões, esta emenda visa a minimizar interferencia do Executivo no Parlamento durante a tramitação da lei orçamentária" (Justificativa de Emenda ao Projeto Ricardo Barros, 13/9/2005). É um enquadramento referente à representação parlamentar.

À primeira vista, parece se tratar de uma "preferência deslocada". Mas não é. O pressuposto teórico de que emendas coletivas interessam aos parlamentares da oposição (por ser uma venue diferente das emendas individuais na qual esses parlamentares podem tentar satisfazer suas preferências orçamentárias) é colocado de ponta-cabeça com essa informalidade denunciada por Laura Carneiro.

\footnotetext{
${ }^{89}$ Tempos depois, Barros escreveu: "[Entre os] assuntos mais difíceis, aqueles em que os ânimos ficavam mais acirrados, estava a redução do número de emendas de bancada para resgatar o caráter coletivo das emendas" (Barros 2007, p. 12).
} 
O mesmo raciocínio é endossado tanto por Ricardo Barros, ao afirmar que o "ministro costuma pedir o atendimento de sua emenda de comissão" (Comissão 2005, 31/2005, p. 264, grifo meu), quanto pelo deputado Sérgio Miranda, do PC do B pertencente à coalizão: "Não concordo com a diminuição do papel e do sentido das emendas de comissão. São as emendas do Brasil. Não temos nenhuma forma de ajudar o Projeto Antártica, o Aramar ou a Rede Sarah se não for por uma comissão, porque são emendas de projetos mais abrangentes. Aumentou-se excessivamente o valor das emendas de bancada, e as emendas de comissão vêm minguando. (...) Serei um advogado das emendas de comissão. Não viabilizaremos nenhum projeto na área de Ciência e Tecnologia sem uma emenda de comissão importante para aquele setor" (Comissão 2005, 7/4/2005, p. 208).

Este tipo de informalidade não é inédita. No Paraguai, país onde formalmente apenas o Ministério da Fazenda pode negociar assuntos orçamentários, diversos ministros negociam dotações orçamentárias de modo informal com parlamentares (Molinas et. al 2009, p. 185) ${ }^{90}$.

Nas discussões ao longo de 2005, Barros concordou em manter as emendas de comissão, contrariando as preferências expostas em março de 2005. Pode ser um exemplo de negociação deste entrepreneur, pois, como vimos, as emendas de comissão interessam fortemente ao Executivo. Afinal, a Resolução 1/2006 manteve tanto as emendas de bancada estadual quanto as de comissão, dividindo-as entre as de "apropriação" (que podem utilizar receitas especificamente destinadas a emendas parlamentares) e as de "remanejamento" (que podem cancelar certas dotações orçamentárias, sugerindo outras) ${ }^{91}$.

Resta tratar de um paradoxo: se as emendas coletivas são um possível instrumento para a oposição satisfazer preferências orçamentárias, por que elas sobreviveram à critical juncture de 1994-1995, quando a coalizão controlou plenamente a agenda? ${ }^{92}$ A resposta está relacionado aos escândalos de corrupção. Emendas individuais são mais associadas a atos corruptos. Emendas coletivas, por exigirem algum tipo de acordo entre diversos parlamentares, são vistas como instituições "limpas" e "consensuais", para usar a terminologia de Pereira e Orellana (2009).

\footnotetext{
${ }^{90}$ Há também vários exemplos de pedidos de ministérios para relatores setoriais do orçamento, algo que indica que ministros buscam aumentar seus orçamentos não só na discussão interna ao Executivo como também na discussão parlamentar.

${ }^{91}$ Ver a terceira tabela do Anexo I a este capítulo para mais detalhes.

${ }^{92}$ Ver discussão extensa sobre este controle no segundo capítulo.
} 
Portanto, são menos associadas a atos corruptos. Vale ressaltar que mesmo o relatório da CPI das Ambulâncias, após ter identificado o uso corrupto de diversas emendas de bancada em Mato Grosso (Relatório da CPI das Ambulâncias, 2006, p. 73), sugeriu o "fortalecimento das emendas coletivas". É claro que acordos corruptos podem envolver diversos atores da mesma arena política, mas há medidas mais claras para combater esse tipo de ato corrupto - o rodízio de membros, por exemplo (ver Abbink 2004 e Kalnins 2005) - do que atos que envolvem apenas um parlamentar.

\section{4) Valor de Emendas coletivas}

Por que o valor destinado anualmente para atender emendas coletivas não é limitado enquanto o valor das emendas individuais é limitado pelo relator-geral em seu parecer preliminar? A resposta está contida na pergunta. Não há limite ao valor das emendas coletivas porque as emendas individuais são limitadas.

Uma das recomendações da CPI dos "anões do orçamento", em 1994, foi fixar valores "com critérios de proporcionalidade" não específicos para emendas coletivas. Esta recomendação não foi acatada na Resolução 2/1995. O assunto voltou à tona apenas onze anos depois, quando o então presidente da Comissão Mista de Orçamento, Paulo Bernardo, recomendou, em ofício enviado ao presidente do Congresso Nacional, a redução no limite de emendas coletivas. Esta medida é coerente com seu interesse referente ao pertencimento à coalizão.

No entanto, medida contrária foi sugerida pelo entrepreneur Ricardo Barros em seu projeto de resolução de julho de 2005. Barros propôs que o "parecer preliminar deverá estabelecer o valor mínimo das emendas de apropriação de bancadas estaduais. Os recursos virão de: reestimativa de receita, reserva de contingência e outros definidos no parecer preliminar, deduzidos os recursos para atender emendas individuais, despesas obrigatórias e outras obrigações definidas no mesmo parecer; além disso, os recursos para emendas de bancada estadual serão distribuídos na proporção de um terço com base na média histórica de atendimento das respectivas bancadas nos últimos 3 anos, um terço com base nos critérios estabelecidos para o Fundo de Participação dos

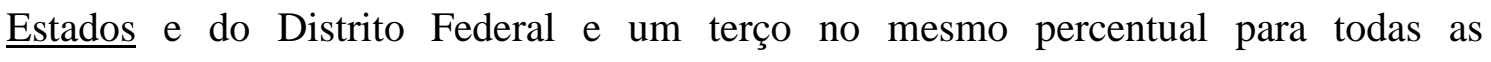


bancadas ${ }^{93}$ ". É uma proposta coerente com os interesses de Barros relativos ao pertencimento à oposição.

O deputado Luciano Castro, líder do PL, um dos partidos da coalizão, apoiou esta proposta, estendendo-a às emendas de comissão, incorrendo em um exemplo de "preferência deslocada". Ronaldo Dimas, do PSDB e da oposição, também defendeu a sugestão (Comissão 2005, 20/4/2005, p. 57-58).

Por fim, a Resolução 1/2006 foi aprovada com a solução sugerida por Ricardo Barros, à exceção dos critérios para distribuir recursos para emendas de bancada estadua. Foram definidos do seguinte modo: $50 \%$ com base nos critérios estabelecidos para o Fundo de Participação dos Estados; 40\% com base na série histórica de atendimento das respectivas Bancadas Estaduais nos últimos três anos e 10\% com base na população residente estimada pelo IBGE.

A idéia de que o limite às emendas individuais é compensado pela falta de limite de valor para as emendas coletivas é corrente entre parlamentares, imprensa e analistas. Para o consultor técnico da Câmara dos Deputados Helio Tollini (2009, p. 12), “os deputados e senadores têm progressivamente usado as emendas coletivas como um instrumento para escapar das limitações impostas às emendas individuais". Esta interação é vista também no diagnóstico de Ricardo Barros, para quem "as emendas individuais teriam que necessariamente ser executadas para que os parlamentares concordassem em reduzir o valor das emendas de bancada estadual" (Comissão 2005, 7/4/2005, p. 184-185).

O comportamento de alguns relatores-gerais do orçamento também ilustra essa opção institucional. Dois exemplos da imprensa a seguir: i) "O relator-geral do orçamento, Delcídio Amaral (PT), comentou a respeito das emendas individuais, que passaram de R \$ 8 milhões para R\$ 10 milhões por parlamentar. Segundo Delcídio, que se manifestou contra o aumento em seu relatório, o valor final global autorizado para todas as emendas não aumentou. 'Nós cortamos as emendas de comissões e de bancada. Com isso, apesar do aumento da quantia das emendas individuais, o montante final não ficou maior', explicou"94; ii) "Parlamentares reclamam que o corte de 57\% aplicado

\footnotetext{
${ }^{93} \mathrm{O}$ parlamentar sugeriu a seguinte distribuição de recursos para emendas coletivas: a) $25 \%$ para emendas de bancada estadual; b) $55 \%$ para relatores setoriais distribuírem entre emendas de bancada estadual e emendas de comissão; c) $20 \%$ para relator-geral distribuir entre emendas de bancada estadual e emendas de comissão; d) o relator-geral deve assegurar que emendas de comissão recebam pelo menos $15 \%$ dos recursos livres.

94 Delcídio espera votar orçamento até quinta-feira", Leandro Kleber, Contas Abertas, 15/12/2008, http://contasabertas.uol.com.br/noticias/detalhes_noticias.asp?auto=2500
} 
pelo relator-geral José Pimentel (PT) nas emendas coletivas, reduzindo os recursos de $\mathrm{R} \$ 23,9$ bilhões para $\mathrm{R} \$ 10,1$ bilhões, vai afetar a realização de obras estruturais de suas cidades. Em contrapartida, Pimentel preservou as emendas individuais dos parlamentares, que chegam a $\mathrm{R} \$ 4,75$ bilhões. O enxugamento das emendas de bancada faz parte da ginástica financeira desenvolvida pelo relator para recompor parte do montante que seria arrecadado com a CPMF. A decisão de Pimentel, tomada com o apoio do Colégio de Líderes, não alegrou muita gente. A bancada do Nordeste é a que mais reclama da tesourada, alegando que no setor de infra-estrutura, apenas R\$ 111 milhões foram destinados para o Piauí, enquanto para outros Estados, como Minas Gerais, foram reservados R \$ 1,2 bilhão"95.

Esta última notícia ilustra, alias, o principal enquadramento utilizado tanto para defender quanto atacar o valor ilimitado para emendas coletivas: o relativo à representação de interesses de estados. O deputado Pauderney Avelino, do PFL (oposição), afirmou: "Não podemos tratar os desiguais de forma igual. As emendas de estado rico e de estado pobre podem até ser na mesma quantidade, mas temos de criar critérios para distribuição dos recursos de forma desigual, haja vista que a distribuição do Fundo de Participação dos Estados é inversamente proporcional à população e à arrecadação de tributos no Estado, exatamente para se fazer um pouco mais de justiça" (Comissão 2005, 31/3/2005, p. 116-117). Favorável à limitação do valor de emendas coletivas, Fernando Bezerra, do PTB (coalizão), disse: "No caso das emendas de bancada, minha idéia é muito próxima à de Garibaldi Alves. Definido um valor global, seria rateado entre as bancadas pelo critério utilizado no Fundo de Participação dos Estados" (Comissão 2005, 20/4/2005, p. 72).

Ambos os parlamentares agem de acordo com seus interesses de curto prazo (pertencimento à coalizão ou oposição) utilizando o mesmo enquadramento que revela um interesse de longo prazo: representar bem seus estados. Todos os enquadramentos referentes a algum tipo de representação parlamentar estão relacionados a interesses de longo prazo porque a "boa representação" é algo que fortalece o Legislativo como ator coletivo ao longo do tempo.

Esses discursos têm duas outras características em comum. A primeira é que ambos os parlamentares incorrem no que Henson e Benoit (2009) chamam de "federalismo funcional". O argumento é que atores com competências nacionais dão

\footnotetext{
95 "Parlamentares brigam por emendas para os Estados", Márcio Falcão, Jornal do Brasil, 22/2/2008
} 
saliência a aspectos "nacionais", enquanto políticos com competências estaduais dão saliência a aspectos estaduais. Tanto Avelino quanto Bezerra são eleitos em estados e têm competências típicas desta jurisdição, sobretudo o senador.

A segunda característica é que ambos são favoráveis a algum tipo de repartição dos recursos baseado no Fundo de Participação dos Estados. Vale lembrar que Ricardo Barros propôs, em seu projeto de 2005, que "os recursos para emendas de bancada estadual serão distribuídos na proporção de um terço com base na média histórica de atendimento das respectivas bancadas nos últimos 3 anos, um terço com base nos critérios estabelecidos para o Fundo de Participação dos Estados e do Distrito Federal e um terço no mesmo percentual para todas as bancadas". Tanto Avelino quanto Bezerra sugerem que este critério do FPE, que beneficia estados com menos recursos, seja o único utilizado para dividir o dinheiro das bancadas estaduais. Barros aquiesceu parcialmente. O resultado final na Resolução 1/2006 é que metade dos recursos serão alocados de acordo com o FPE, $40 \%$ com base na média histórica de atendimento das bancadas estaduais nos últimos três anos e 10\% com base na população residente estimada pelo IBGE. É um bom exemplo de como um entrepreneur negocia alguns pontos de modo a tentar formar maioria para aprovar outros.

A principal lição a tirar desse caso é que algumas escolhas institucionais podem não ser bem compreendidas quando estudadas isoladamente. O limite ao valor global de emendas individuais poderia, à primeira vista, parecer uma medida eficaz contra o gasto parlamentar, talvez orientada pela coalizão presidencial. No entanto, quando colocado ao lado da falta de limite de valor para as emendas coletivas (e a crescente utilização destas, como mostra a tabela 4.1), torna-se uma decisão institucional mais plausivelmente associada a escândalos de corrupção. Afinal, o parlamentar poderia dizer para seus representados, sem mentir, que anualmente é estabelecido um limite para as emendas individuais. Caberia ao eleitor associar esta decisão à outra. A exigência informacional é altíssima, pois este trade-off das emendas individuais pelas coletivas é extremamente dinâmico e orientado, em parte, por uma lógica informal a ser tratada em outro capítulo.

\section{5 ) Natureza de Emendas coletivas}

A natureza de emendas individuais, como vimos, foi limitada ao longo do tempo devido, em parte, à influência de escândalos de corrupção, que associaram 
oportunidades corruptas à falta de limites da natureza dessas emendas. Algo bastante semelhante aconteceu com a natureza de emendas coletivas, em um caso que também contou com a presença decisiva do entrepreneur Ricardo Barros. A força de Barros vem do fato de ele ter sido relator do grupo de trabalho criado em 2005 para discutir a reestruturação do processo orçamentário ${ }^{96}$.

Em 1993, a primeira resolução congressual que permitiu emendas coletivas definiu sua natureza de modo espartano. Eram dois pontos, um afirmando que emendas de comissão seriam sobre matérias "pertinentes regimentalmente" e acompanhadas da ata da reunião em que foram deliberadas, e outro dizendo que as emendas de bancada estadual tratariam de projetos “de interesse estadual”. A Resolução 2/1995, seguindo sugestões inicialmente aventadas por assessores técnicos do orçamento ${ }^{97}$, adicionou diversos pontos que, embora não limitem, na prática, a natureza das emendas coletivas, exigem que elas sejam bem justificadas pelos parlamentares. Segundo a resolução, a emenda coletiva tem que: i) trazer referência a pré-projeto de viabilidade; ii) indicar fonte de financiamento e eventuais contrapartidas; iii) trazer relatório de impacto ambiental; iv) conter relação de custo/benefício sócio-econômico e v) trazer prazos de execução.

O início da experiência com emendas de bancada estadual pareceu ser apropriado. O relator-geral do processo orçamentário de 1999, Ramez Tebet, afirmou em seu parecer preliminar ter identificado "fontes capazes de melhorar substancialmente a peça orçamentária, atendendo às prioridades nacionais que, regra geral, as emendas coletivas tão adequadamente expressaram ${ }^{98}$ ". Samuels (2002, p. 329) concorda que emendas de bancada estadual atendem a interesses parlamentares diferentes das emendas individuais, dizendo que "embora a bancada pudesse dividir individualmente as emendas, para que cada parlamentar atendesse suas bases, entrevistados confirmam que a bancada se reúne para decidir coletivamente, com a crucial influência do governador".

No entanto, há diversas evidências de que emendas de bancada estadual são tratadas como individuais, incorrendo no que costuma-se chamar de "rachadinhas". Trata-se da divisão informal de emendas coletivas com o objetivo de beneficiar

\footnotetext{
${ }^{96} \mathrm{O}$ segundo capítulo traz mais detalhes sobre isso.

${ }^{97}$ Ver a tabela cinco do anexo II a este capítulo para o histórico completo das idéias em circulação.

${ }^{98}$ Comissão Mista de Orçamento. Parecer Preliminar sobre o Projeto de Lei n. 41,1998-CN, que estima a receita e fixa a despesa da União para o exercício financeiro de 1999. Relator-Geral: Ramez Tebet. 17 de janeiro de 1999, p. 3.
} 
parlamentares individualmente. Para isto, a emenda coletiva descreve uma ação extremamente genérica, sem especificar localizações geográficas além do estado. Isso permite que os parlamentares dividam, quando da execução da emenda, os méritos de ações específicas. Uma explicação encontrada na imprensa ajuda a esclarecer: "A principal pista para se reconhecer uma "rachadinha" no meio do emaranhado de emendas apresentadas ao Orçamento é o seu enunciado. Em um exemplo clássico, a bancada paulista no Congresso destinou, para este ano, R \$ 135 milhões para a "Estruturação de unidades de Atenção Especializada em Saúde" no Estado. Não há detalhes sobre quais municípios ou entidades serão agraciados. A descrição genérica dessas emendas facilita a divisão do valor entre parlamentares depois que a rubrica é aprovada. Dessa forma, o destino dos recursos é decidido depois que a emenda for liberada pelo Executivo, de acordo com os interesses dos parlamentares"99.

Como as "rachadinhas" foram limitadas formalmente? A idéia inicial foi de Ricardo Barros, em documento que circulou na comissão formada em 2005 para discutir a reestruturação do processo orçamentário ${ }^{100}$. O parlamentar propôs "critérios mais rígidos para a aprovação de emendas de bancada: localização geográfica específica, repetição da emenda nos exercícios subseqüentes até a conclusão de seu objeto". Tratase de uma "preferência deslocada" de Barros: afinal, como representante da oposição, pouco deveria lhe interessar impor limites à natureza das emendas coletivas.

Em seu projeto de resolução proposto em julho de 2005, Barros aprofundou a proposta. Para ele, as "emendas de bancada estadual que tratam de projetos deverão identificar de forma precisa o objeto da ação pretendida, vedada a designação genérica de ações que possam contemplar obras distintas em sua execução; e atender, alternativamente, a projetos de grande vulto,(...); ou projetos estruturantes de interesse nacional ou estadual, nos termos do parecer preliminar, especificando-se o objeto do gasto e a localização do empreendimento" e "as emendas de bancada, uma vez propostas e iniciadas com recursos federais, deverão necessariamente ser objeto de emendas coletivas até a sua conclusão, desde que esses não constem do projeto de lei encaminhado pelo Executivo".

Ninguém se manifestou contra essa proposta à época. Aliás, a CPI das Ambulâncias ajudou a guiar os parlamentares a favor da limitação. O esquema das

\footnotetext{
99 "Emendas rachadas corrompem orçamento", Karla Correia, Jornal do Brasil, 20/3/2008.

100 Agradeço imensamente o assessor técnico Carlos Marshall, do Senado Federal, por permitir acesso a este documento.
} 
ambulâncias utilizou-se de diversos tipos de dotações orçamentárias, tanto de emendas individuais quanto coletivas, e até de dotações que já vieram da proposta do Executivo, sem depender de emenda parlamentar (Relatório da CPI das Ambulâncias, 2006, p. 73). No entanto, as emendas coletivas "rachadinhas" levaram a pecha de mais associadas à corrupção do que outros tipos de emenda: "A máfia dos sanguessugas aproveitava-se das emendas rachadas para embolsar recursos que deveriam ser usados para a compra de ambulâncias"101. Mesmo o relatório da CPI afirmou que, entre as principais deficiências do processo orçamentário, estava o "desvirtuamento do papel das emendas coletivas de definição de projetos estruturantes" (Relatório da CPI das Ambulâncias, 2006, p. 76).

O cenário para a limitação formal das rachadinhas estava dado. A atenção dos parlamentares à investigação da CPI das Ambulâncias se torna notável ao analisarmos um detalhe. A CPI recomendou "tornar punível a falta de cumprimento das normas relativas à formalização dos convênios, especialmente em relação à definição do plano de trabalho, especificação precisa do objeto e dos custos associados" (grifo meu). Em adendo a seu substitutivo ao projeto de Ricardo Barros, José Carlos Aleluia inseriu a seguinte frase: "[As emendas coletivas devem] identificar de forma precisa o seu objetivo, vedada a designação genérica de programação que possa contemplar obras distintas ou possam resultar, na execução, em transferências voluntárias, convênios ou similares, para mais de um ente federativo ou entidade privada" (grifo meu). Isto foi aprovado, em completo consenso, na Resolução 1/2006.

No entanto, um recente projeto de resolução, proposto pelo senador governista Delcício Amaral propõe a volta das "rachadinhas". De acordo com o projeto (PRN 4/2008), "as emendas de bancada estadual devem poder contemplar um conjunto articulado de obras em todo o estado, não podendo ficar limitadas a um município ou região metropolitana, desde que exista, previamente, programa específico”. Além disso, Amaral afirma que "deve-se reconhecer a legitimidade da bancada buscar atender todo o estado com determinada política pública, ficando ao encargo do órgão executor, o Estado ou a União, a definição dos critérios de elegibilidade dos municípios onde serão realizadas as obras". Portanto, pode haver certo "prazo de validade" para algumas das medidas implementadas devido a escândalos de corrupção e a ação de entrepreneurs.

101 "Emendas rachadas corrompem orçamento", Karla Correia, Jornal do Brasil, 20/3/2008. 
A regra mais importante referente à natureza das emendas de comissão foi aprovada na Resolução 1/1993, afirmando que as emendas de comissão devem tratar de temas "pertinentes regimentalmente". Isto indica que nenhuma comissão deveria propor emendas em áreas de jurisidição de outra comissão. Há indícios de que esta regra não tenha sido bem obedecida ao menos em uma época próxima a 2005, pois naquele ano dois parlamentares (um da coalizão, outro da oposição) reclamaram que as emendas de comissão deveriam se ater às áreas temáticas determinadas regimentalmente. Gilmar Machado, do PT (coalizão), utiliza um enquadramento referente à eficiência processual do Legislativo para frisar este ponto: "A emenda tem de ser relativa ao tema da comissão, senão cada um vai começar a inventar. No ano passado fiquei impressionado com a criatividade das comissões, cada uma querendo entrar em outras áreas para apresentar emendas" (Comissão 2005, 31/3/2005, p. 115). Este clamor pelo respeito a um limite à natureza das emendas de comissão seria coerente, à primeira vista, com os interesses de um parlamentar pertencente à coalizão. No entanto, conforme já foi discutido acima, as emendas de comissão têm sido constantemente utilizada por ministérios que não conseguem fazer valer suas preferências em outras etapas do processo orçamentário. Portanto, Gilmar Machado mostra uma "preferência deslocada" neste caso. Seu enquadramento revela um interesse de longo prazo referente ao Legislativo como ator coletivo: afinal, um parlamento no qual comissões se envolvem em guerras jurisdicionais (turf wars) cotidianamente tende a se tornar menos legítimo.

$\mathrm{O}$ discurso de Machado parece ter encontrado ouvintes. Embora o entrepreneur Ricardo Barros não tenha se pronunciado sobre o assunto, o que indica que isto não estava entre suas prioridades, a Resolução 1/2006 aprovou ao menos três pontos que aquiescem ao que disse o parlamentar petista: i) emendas de comissão devem ter “caráter institucional e representar interesse nacional”, vedada a destinação a entidades privadas, salvo se contemplarem programação constante do projeto; ii) emendas de comissão devem conter, na sua justificação, elementos, critérios e fórmulas que determinem a aplicação dos recursos, em função da população beneficiada pela respectiva política pública, quando se tratar de transferências voluntárias de interesse nacional e iii) emendas de comissão que remanejam recursos somente poderão propor acréscimos e cancelamentos em dotações de caráter institucional e de interesse nacional, no âmbito da mesma subárea temática e mesmo grupo de natureza de despesa, observada a compatibilidade das fontes de recursos. Além disso, a Resolução 1/2006, 
em um anexo, determinou com clareza quais áreas temáticas são de jurisidição de quais comissões.

O recente projeto de resolução de Delcídio Amaral, PRN 4/2008, combate diretamente esta última medida, pedindo a "simplificação da regra de apresentação das emendas de comissão: extinção da correlação com as áreas e subáreas temáticas". A justificativa do senador é: "A regra atual estabelecia correlação entre a competência regimental das comissões permanentes da Camara e Senado com os órgãos da administração pública federal. A intenção original foi a de evitar que diversas comissões apresentassem emenda para a mesma programação. Todavia, a norma criou limitações e conflitos com a dinâmica das atribuições regimentais das comissões e que estão previstas nos Regimentos Internos de ambas as Casas. Portanto, sugerimos que a competência de emendamento das comissões se atenha apenas às suas atribuições regimentais, como era a prática desde a Resolução 2/1995."

O que Amaral não diz é que a falta de regras claras sobre jurisdição das comissões temáticas permite que a comissão X entre na turf da comissão $\mathrm{Y}$, pois talvez o ministério a que a comissão Y é ligada costuma ter melhor desempenho na execução orçamentária do governo federal. Isto só é possível devido à atuação permissiva do Comitê de Admissibilidade de Emendas, algo que vale analisar no futuro.

Após esta detalhada exposição das escolhas institucionais relativas a emendamento orçamentário, vale retomar os principais argumentos do capítulo. O principal é que as idéias dos parlamentares a respeito das prerrogativas de emendamento podem ser consoantes ou não com os interesses desses atores politicos. Quando as idéias não são consoantes com os interesses, configuram o que chamo de "preferências deslocadas" dos atores. Trata-se, por exemplo, de um ator que tem interesses A e B para apoiar a instituição $X$ (os interesses podem ser pela reeleição e pertencimento à coalizão; a instituição pode ser "emendas individuais ilimitadas"), mas defende o fim (ou limitação parcial) desta instituição.

Um dos fenômenos que as "preferências deslocadas" ajudam a entender é a interação entre interesses de curto e longo prazo em critical junctures. Para justificar suas "preferências deslocadas", os parlamentares tendem a utilizar enquadramentos 
discursivos que privilegiam interesses de longo prazo e mascaram certos interesses de curto prazo. Diversos enquadramentos foram analisados acima, ilustrando este aspecto.

Propus que as idéias orientadas por "preferências deslocadas" têm mais chances de sucesso: i) quanto mais elas puderem ser associadas, através de enquadramentos, aos escândalos de corrupção que perfazem o background das CJs analisadas nesta tese. Isto pode ser avaliado do seguinte modo: se o relatório de uma CPI que investiga corrupção orçamentária propõe a idéia X, é porque esta idéia está associada ao escândalo?; e ii) quanto maior for a capacidade de persuasão dos entrepreneurs, medida com base na influência deles no controle da agenda, nos recursos que investiram e nos enquadramentos estratégicos que utilizaram para convencer os atores. O resultado institucional será tanto mais paradoxal quanto mais ele contrariar os interesses dos atores $^{102}$. A tabela 4.2 sistematiza os casos estudados.

Tabela 4.2: Corrupção, entrepreneurs e escolhas sobre emendamento, 1988-2008

\begin{tabular}{|l|l|l|l|l|}
\hline & $\begin{array}{l}\text { Caso pode ser } \\
\text { associado à } \\
\text { corrupção? }\end{array}$ & $\begin{array}{l}\text { Atores tinham } \\
\text { preferências } \\
\text { deslocadas? }\end{array}$ & $\begin{array}{l}\text { Entrepreneur em } \\
\text { 2006 tinha } \\
\text { preferências } \\
\text { deslocadas? }\end{array}$ & $\begin{array}{l}\text { Resultado final } \\
\text { é paradoxal ou } \\
\text { não? }\end{array}$ \\
\hline $\begin{array}{l}\text { Número de } \\
\text { emendas } \\
\text { individuais }\end{array}$ & Sim & Sim & Sim & $\begin{array}{l}\text { Sim (2006); } \\
\text { Não (1995) }\end{array}$ \\
\hline $\begin{array}{l}\text { Natureza de } \\
\text { emendas } \\
\text { individuais }\end{array}$ & Sim & Não & Sim & $\begin{array}{l}\text { Sim (2006); } \\
\text { Sim (1995) }\end{array}$ \\
\hline $\begin{array}{l}\text { Número e atores: } \\
\text { emendas de } \\
\text { bancada estadual }\end{array}$ & Sim & Não & Sim & $\begin{array}{l}\text { Não (2006); } \\
\text { Sim (1995) }\end{array}$ \\
\hline $\begin{array}{l}\text { Número e atores: } \\
\text { emendas de } \\
\text { comissão }\end{array}$ & Não & Não & Sim & $\begin{array}{l}\text { Não (2006); } \\
\text { Sim (1995) }\end{array}$ \\
\hline $\begin{array}{l}\text { Valor de emendas } \\
\text { coletivas }\end{array}$ & Não & Não & Não & $\begin{array}{l}\text { Não (2006); } \\
\text { Não (1995) }\end{array}$ \\
\hline $\begin{array}{l}\text { Natureza de } \\
\text { emendas coletivas: } \\
\text { emendas de } \\
\text { bancada estadual }\end{array}$ & Sim & Não & Sim & $\begin{array}{l}\text { Sim (2006); } \\
\text { Sim (1995) }\end{array}$ \\
\hline $\begin{array}{l}\text { Natureza de } \\
\text { emendas coletivas: } \\
\text { emendas de } \\
\text { comissão }\end{array}$ & Não & Sim & Não & $\begin{array}{l}\text { Não (2006); } \\
\text { Sim (1995) }\end{array}$ \\
\hline
\end{tabular}

\footnotetext{
102 No caso deste capítulo, são os interesses referentes à reeleição e ao pertencimento ou não à coalizão. O interesse no Legislativo como ator coletivo é utilizado nos diversos enquadramentos discursivos, como vimos.
} 
Há dois pontos importantes a considerar a partir dos casos analisados. O primeiro é que todos os resultados paradoxais em 2006 são associados à corrupção e com clara influência de um entrepreneur. Com relação ao número de emendas individuais, tanto a CPI dos “anões do orçamento" em 1993-1994 quanto a CPI das Ambulâncias em 2006 recomendaram o fim desse tipo de emenda. Parlamentares de coalizão e oposição protestaram contra esta recomendação das CPIs, utilizando o enquadramento discursivo referente à representação. O fato de tanto membros da coalizão quanto a oposição defenderem a existência de emendas individuais mostra que esta instituição é mais ligada ao interesse pela reeleição, compartilhado por todos os parlamentares, do que a outros tipos de interesse. No entanto, respondendo à pressão da opinião pública relativa aos escândalos, diversos parlamentares apoiaram o fim das emendas individuais, incorrendo em "preferências deslocadas". Para isso, utilizaram enquadramentos referentes à corrupção, barganha política e eficiência processual.. A Resolução 1/1993 fixou em 50 o limite de emendas individuais por parlamentar. Este número diminuiu para 20 emendas na Resolução 2/1995. Nas discussões de 2005, havia quem quissesse um aumento no número de emendas, mas isto foi brecado com a investigação dos “sanguessugas” em 2006. A Resolução 1/2006, por fim, limita a 25 emendas individuais por parlamentar.

As “janelas orçamentárias” são a maneira mais comum de subverter a natureza das emendas individuais. Trata-se de dotações orçamentárias com "valores simbólicos ou irreais", a serem suplementados posteriormente. Os debates sobre a natureza de emendas individuais no periodo analisado se deram em torno dessas "janelas orçamentárias", especialmente na critical juncture de 2005-2006, por iniciativa do entrepreneur Ricardo Barros. Mas por que um parlamentar proporia limitações à natureza das emendas individuais? A teoria de interesses da escolha racional, a partir da qual o deputado só agiria de acordo com seu interesses em se reeleger, pertencer à coalizão e/ou ter acesso a um posto de poder institucional, não fornece resposta para este caso. É, portanto, uma "preferência deslocada" de Barros. O resultado final veio na Resolução 1/2006, que propõs uma limitação formal às "janelas orçamentárias”. A importância do entrepreneur é sublinhada pelo fato de que outras propostas relativas à natureza de emendas individuais avançadas pela CPI das Ambulâncias em 2006 não tiveram sucesso.

O segundo ponto é como as escolhas institucionais expostas acima estão ligadas em um todo analítico, referente ao caminho de layering institucional 
percorrido. Há quatro caminhos de mudança resultantes das escolhas de atores, segundo Mahoney e Thelen (2009). Trata-se da extinção de regras antigas e a introdução de novas (displacement); a introdução de novas regras que convivem com antigas regras (layering); novos efeitos de regras antigas devido a mudanças no ambiente institucional (drift); uso estratégico de regras antigas, resultando em novos efeitos institucionais (conversion).

À primeira vista, o caso das emendas individuais e coletivas no Brasil pós-1988 poderia ser um exemplo de displacement. Afinal, o fim das emendas individuais foi uma idéia proposta de modo recorrente. Não teria sido muito estranho se elas fossem extintas e as emendas coletivas tomassem completamente seu lugar. Instituições competem. Diversos atores políticos quiseram, ao menos em algum momento, que as emendas coletivas vencessem esta "competição" contra as emendas individuais. Mas não foi isso que ocorreu, como vimos acima. As emendas orçamentárias propostas individualmente pelos parlamentares foram progressivamente deslegitimadas após dois escândalos de corrupção e isso não resultou no fim dessa instituição, mas sim na prioritização, ao longo do tempo, de emendas coletivas (propostas atualmente por bancadas estaduais e comissões parlamentares).

Conforme Mahoney e Thelen (2009, p. 25) afirmam, veto players poderosos podem proteger regras antigas, mas não necessariamente impedir a adição de novas. Isto é layering. Foi o que ocorreu com as emendas individuais e coletivas. Não houve a extinção de regras antigas - apesar de forte pressão para isso nas critical junctures analisadas acima; não houve o negligenciamento progressivo das regras antigas nem uma mudança no impacto das regras antigas - afinal, as emendas individuais não deixaram de ser utilizadas pelos parlamentares, como mostra a tabela 4.1 deste capítulo; e houve a introdução de novas regras - pois as emendas coletivas só passaram a existir depois de 1993 e as regras sobre elas foram se aperfeiçoando em várias resoluções congressuais desde então ${ }^{103}$.

Para concluir, vale ressaltar alguns dos pontos teóricos a pensar a partir deste capítulo. A discussão acima mostrou como a direção de mudanças institucionais é definida por critical junctures, com forte ênfase em quem controla a agenda em cada critical juncture, conforme Capoccia e Kelemen (2007) afirmam ser importante. O

\footnotetext{
103 A não-extinção de regras antigas, a falta de negligenciamento delas ou a falta de mudança no seu impacto - ao lado de novas regras - são as condições que satisfazem o processo de layering para Mahoney e Thelen (2009, p. 49).
} 
impacto da ação de entrepreneurs também é bem sublinhado, frisando como este ator pode perder alguns pontos e ganhar outros, evitando uma definição tautológica do entrepreneur como "aquele que tem sucesso". Mostrei, também, como enquadramentos discursivos são mobilizados por atores em critical junctures para defender, sobretudo, suas "preferências deslocadas" (contrárias a seus interesses de curto prazo). Por fim, a discussão ilustra em que medida escândalos de corrupção realmente afetam mudanças institucionais no Brasil, em vez de simplesmente afirmar que "escândalos causam mudanças". O capítulo a seguir trata das escolhas sobre a organização da Comissão Mista de Orçamento sob a mesma ótica, mas com resultados diferentes. 


\section{Capítulo 5}

\section{Conversão institucional: o caso da Comissão Mista de Orçamento}

Este capítulo tem o objetivo de explicar dois paradoxos da organização da etapa legislativa do orçamento no Brasil. O primeiro é: por que a coalizão governista manteve, de 1995 a 2006, basicamente o mesmo desenho institucional que organiza a Comissão Mista de Orçamento da época dos “anões do orçamento"? Essa estabilidade institucional após 1994 faz pouco sentido se esperarmos que o escândalo de corrupção tenha o papel de fazer idéias anti-corrupção circularem e serem adotadas. Algumas dessas idéias são contra a centralização na Comissão Mista de Orçamento que tanto auxiliou o esquema dos "anões do orçamento". No entanto, a coalizão não adotou nenhuma delas na critical juncture terminada em 1995. Este paradoxo pode ser explicado pela importância da comissão centralizada, dotando o relator-geral de diversas prerrogativas importantes, para avançar os interesses orçamentários da coalizão.

O segundo paradoxo é: por que a Comissão Mista de Orçamento não foi descentralizada em 1995, quando havia forte pressão para isso, mas em 2006 ocorreu a descentralização parcial? Com a Resolução 1/2006, o Relator-Geral da comissão perdeu a prerrogativa de estimar a receita unilateralmente, por exemplo, e relatores setoriais se tornaram mais poderosos. Este paradoxo pode ser explicado pela bem-sucedida estratégia do entrepreneur Ricardo Barros, da oposição, em 2006. Barros conseguiu driblar o controle da agenda da coalizão através de sucessivas chantagens e negociações. Concedeu em alguns pontos - desistiu, por exemplo, de fazer a oposição indicar um Relator da Receita - e manteve-se firme em outros ${ }^{104}$.

A primeira decisão é paradoxal não por contrariar interesses de curto prazo da coalizão - como vimos no segundo capítulo, uma comissão centralizada é bastante condizente com esses interesses -, mas por ser contra diversas idéias em circulação na critical juncture de 1994-1995. Este paradoxo é um exemplo do processo de mudança institucional chamado por Mahoney e Thelen (2009) de "conversão institucional". Três aspectos institucionais ligados à comissão - a saber, a prerrogativa de o Relator-Geral

\footnotetext{
${ }^{104}$ O próximo capítulo mostra que o senador Antônio Carlos Magalhães quase conseguiu o mesmo em relação ao Orçamento Impositivo, mas os stakes eram mais altos: tratava-se da obrigatoriedade de o Executivo implementar o orçamento alterado pelo Legislativo.
} 
emendar o orçamento, estimar a Receita e sua autonomia decisória - tiveram um uso entre 1989-1993 (tempo 1) e outro uso entre 1994-2006 (tempo 2), o que configura conversion. A próxima seção avalia como os "anões do orçamento" usaram esses aspectos institucionais a seu favor e, posteriormente, a coalizão liderada pelo Executivo durante dois governos distintos deu novo significado para eles.

A segunda decisão é paradoxal por ser contra os interesses de curto prazo da coalizão. Afinal, quanto mais descentralizada a Comissão Mista de Orçamento, mais custoso é controlar seus principais postos de poder. Este paradoxo pode ser explicado através de uma abordagem analítica que considera a interação entre idéias e interesses tanto de curto prazo quanto de longo prazo - durante critical junctures. Idéias podem ser consoantes com os interesses de curto prazo dos atores, ou podem ser contrárias a esses interesses, configurando "preferências deslocadas". Trata-se de um ator que tem interesses A e B para apoiar a instituição X mas defende o fim (ou limitação parcial) desta instituição. As idéias orientadas por "preferências deslocadas" têm mais chances de sucesso: i) quanto mais elas puderem ser associadas, através de enquadramentos, a choques sistêmicos, tais como os escândalos de corrupção ${ }^{105}$ que perfazem o background das CJs. Isto pode ser avaliado do seguinte modo: se o relatório de uma CPI que investiga corrupção orçamentária propõe a idéia $X$, é porque esta idéia está associada ao escândalo; e quanto maior for a influência de entrepreneurs, no controle da agenda de uma critical juncture, nos recursos que investiram e nos enquadramentos estratégicos que utilizaram para convencer os atores de suas propostas.

Antes de tratar de ambos os paradoxos, cabe relembrar os interesses parlamentares que orientam esta discussão. Interessaria fortemente à coalizão governista dentro do Legislativo estabelecer uma comissão centralizada, pois o Regimento Interno do Congresso Nacional dispõe que as comissões são compostas de acordo com critérios de proporcionalidade partidária. O Executivo, através dos membros da coalizão no Legislativo, tradicionalmente sela acordos suficientes para indicar o Relator-Geral desta comissão. Portanto, quanto mais poderoso o Relator-Geral, melhor para a coalizão. A oposição, por sua vez, é contra um Relator-Geral poderoso e a favor de uma organização descentralizada. Afinal, já que a CMO é tradicionalmente controlada pela coalizão, parlamentares oposicionistas terão maior chance de expressar suas

\footnotetext{
${ }^{105}$ Vale ressaltar que escândalos de corrupção são apenas um dos tipos de choque sistêmico associados a critical junctures. Crises econômicas, sociais e políticas de outra natureza também estão associadas a esses fenômenos.
} 
preferências no orçamento se outras comissões (como a de Finanças e Tributação, de Educação etc.) tiverem mais poder. Supondo que a CMO seja poderosa, a oposição terá interesse em fortalecer os relatores setoriais que auxiliam o Relator-Geral, pois ao menos alguns dos relatores setoriais não deverão ser indicados pela coalizão ${ }^{106}$. Este é o raciocínio que esperamos que oriente a coalizão e oposição de modo geral.

Dois raciocínios podem complementar este. O primeiro é que parlamentares tanto da coalizão quanto da oposição que possuem cargos de modo recorrente na Comissão Mista de Orçamento têm fortes incentivos para defender um desenho institucional no qual esta comissão tenha fortes prerrogativas - ou seja, centralize a organização da etapa legislativa do orçamento em detrimento de outras comissões. Trata-se do que Schickler (2001) chama de "interesse nos postos de poder institucional". O segundo raciocínio é que a preferência de parlamentares da coalizão por uma comissão centralizada pode ser bastante desigual. Alguns parlamentares são bastante indiferentes ao processo orçamentário, nem mesmo apresentando emendas (Mesquita 2009). É importante lembrar também que a execução de emendas parlamentares é apenas um dos mecanismos com os quais o presidente cimenta sua coalizão no Legislativo. Apesar de executar apenas cerca de $70 \%$ das emendas da coalizão e $40 \%$ das emendas da oposição, o Executivo consegue apoio razoável em plenário para suas propostas ${ }^{107}$.

A seção a seguir explica como atores com forte interesse no pertencimento à coalizão (a saber, parlamentares pós-1994) utilizaram três aspectos institucionais da Comissão Mista de Orçamento de modo bastante diferente de atores com forte interesse nos postos de poder institucional durante o período imediatamente anterior (a saber, os “anões do orçamento" entre 1989 e 1993). A segunda seção do capítulo demonstra como esses aspectos institucionais e mais um outro, referente às prerrogativas dos relatores setoriais, foram mantidos ou mudados nas duas critical junctures consideradas nesta tese. Isto é importante para mostrar como os escândalos de corrupção desvendados em 1994 e 2006 influenciaram a agenda de escolhas institucionais. Analiso também os enquadramentos discursivos mobilizados pelos atores politicos e a freqüência de idéias

\footnotetext{
${ }^{106}$ Novamente, o critério para nomear os relatores setoriais é o da proporcionalidade partidária.

107 Nunca é demais dizer que há diversos outros fatores que influenciam o apoio de parlamentares a projetos do Executivo em plenário, provavelmente tão ou mais importantes do que a liberação de emendas. No entanto, não se pode ignorar o papel do processo orçamentário ao menos na tentativa de unir a coalizão pró-governo.
} 
orientadas por "preferências deslocadas", com o objetivo de verificar como o controle da agenda nas critical junctures ocorreu na prática.

\section{(1) Conversão institucional da Comissão Mista de Orçamento, 1988-2006}

A idéia de centralizar a tramitação legislativa do orçamento em uma comissão mista foi implementada em 1969. Entre 14 e 17 de julho daquele ano, reuniu-se uma comissão constitucional convocada por Arthur da Costa e Silva para reformar a Constituição de $1967^{108}$. O orçamento foi rapidamente discutido pela comissão constitucional em 15 de julho de 1969. Costa e Silva pede que se fale sobre orçamento e Pedro Aleixo indica Hélio Beltrão, que afirma: "Este capítulo é extremamente delicado. Sugeri uma redação e entreguei ao Dr. Aleixo. Nessa sugestão, eu mantinha o dispositivo constitucional [de 1967], introduzindo apenas uma novidade: entregar a votação do orçamento não às duas Câmaras (sic), mas ao Congresso reunido, a uma Comissão da Câmara e do Senado" (Vieira 2002, p. 205).

A junta militar que tomou o poder em agosto de 1969, cinco anos depois do golpe inicial, e editou a Emenda Constitucional n. 1 dois meses depois alterou substancialmente a proposta da comissão de debates constitucionais comandada por Aleixo e Costa e Silva. Mas não mudou a tramitação do orçamento pela comissão mista nem a limitação às emendas orçamentárias de parlamentares ${ }^{109}$.

Como vimos no terceiro capítulo, a Assembléia Nacional Constituinte de 19871988 conservou a Comissão Mista de Orçamento ao mesmo tempo em que permitiu que os parlamentares voltassem a emendar o orçamento. No período democrático, a comissão orçamentária foi "redirecionada para novos propósitos, resultando em mudanças relacionadas às funções que elas exercem e/ou os papéis que ocupam no

\footnotetext{
${ }^{108}$ Integraram essa comissão, além de Costa e Silva, o Ministro da Justiça, Luís Antonio da Gama e Silva; o vice-presidente, Pedro Aleixo; o Ministro do Planejamento, Hélio Beltrão; o Ministro do Supremo Tribunal Federal, Temístocles Brandão Cavalcanti; o Chefe da Casa Civil, Rondon Pacheco e os juristas Miguel Reale e Carlos Medeiros da Silva (Vieira 2002). Integraram essa comissão, além de Costa e Silva, o Ministro da Justiça, Luís Antonio da Gama e Silva; o vice-presidente, Pedro Aleixo; o Ministro do Planejamento, Hélio Beltrão; o Ministro do Supremo Tribunal Federal, Temístocles Brandão Cavalcanti; o Chefe da Casa Civil, Rondon Pacheco e os juristas Miguel Reale e Carlos Medeiros da Silva (Vieira 2002).

${ }^{109}$ A Emenda Constitucional n. 1 de 1969, portanto, instituiu a Comissão Mista de Orçamento nos três primeiros parágrafos do artigo 66. Diversos autores (Samuels 2002, p. 317; Souza 2003, p. 354) cometem o equívoco de afirmar que a Comissão Mista de Orçamento foi criada pela Constituição de 1988. A centralização do processo orçamentário por uma ditadura pode ser melhor entendida a partir de Gandhi (2008), para quem ditadores mantêm certas instituições democráticas funcionando com o objetivo, em parte, de fazer policy concessions que agradam oponentes moderados do regime, assim permitindo sua perpetuação.
} 
campo politico" (Thelen 2003, p. 226). É esta a definição de conversão institucional. Este tipo de processo pode resultar de uma mudanca no ambiente que coloca em confronto atores com novos problemas, com os quais eles lidam através do uso inovador de instituições já existentes, ou pode ser consequencia da incorporação de grupos antes marginalizados, que usam instituições herdadas para atingir novos resultados (Thelen 2003, p. 228).

Como a Comissão Mista de Orçamento passou de dominada por agentes autônomos (e corruptos) a fortemente controlada pela coalizão liderada pelo Executivo? De 1988 a 1993, o Executivo tinha controle pleno apenas da etapa da execução orçamentária e isto era suficiente. O objetivo principal era fazer a hiperinflação que assolava o país funcionar a seu favor. Isto ocorria através do mecanismo do contingenciamento, usado pelo Executivo para equacionar as demandas orçamentárias dos diversos ministérios. A partir do contingenciamento, observou-se uma relação simbiótica entre o governo e a inflação, como observou Pinheiro (1996, p. 158-159), A etapa legislativa do processo orçamentário era secundária para o Executivo, considerando que a hiperinflação corroía gradualmente todas as expectativas de arrecadação e despesas a elas vinculadas. Em outras palavras, o Executivo conseguia tornar letra morta praticamente qualquer dispositivo inserido pelos parlamentares que não lhe interessasse.

A partir de 1994, com o fim da hiperinflação a partir do Plano Real e o início da coalizão que elegeria e sustentaria Fernando Henrique Cardoso como presidente até 2002, o Executivo passou a priorizar a Comissão Mista de Orçamento como locus de decisão. Afinal, agora o orçamento passara a contar com números "reais", e a crescente transparência permitiu que o presidente fosse responsabilizado pelos resultados fiscais, emendas orçamentárias não-executadas etc.

Socos e empurrões não foram poupados pela equipe de Cardoso para tomar o controle do orçamento. No fim do governo de Itamar Franco, em 1994, o economista Gustavo Franco teve que segurar Murilo Portugal, secretário do Tesouro Nacional, ligado ao Ministério da Fazenda, no estacionamento de um dos prédios da Câmara dos Deputados. Portugal se atracara com Aurélio Nonô, o novo secretário do Orçamento Federal, ligado ao Ministério do Planejamento. Nonô irritou Portugal ao reclamar do contingenciamento excessivo de verbas pelo Ministério da Fazenda (Fiuza 2006, p. 8587). 
Mais pacificamente, o governo buscou aproveitar-se das regras centralizadoras da comissão orçamentária a seu favor. Antes de analisar detalhadamente como isto ocorreu, cabe a pergunta: quão governista, durante todo o período analisado nesta tese, é a Comissão Mista de Orçamento? A resposta curta é: mais do que o plenário, mas menos do que os partidos pertencentes à coalizão do Executivo. A tabela 5.1 mostra que os membros da Comissão Mista de Orçamento se equipararam à disciplina média do plenário apenas na legislatura 2003-2007. O governismo é medido como a porcentagem de votações em que a média dos parlamentares apoiou o governo.

Tabela 5.1: Governismo da Comissão Mista de Orçamento, 1988-2007 ${ }^{110}$

\begin{tabular}{|l|l|l|l|}
\hline & Disciplina da CMO & $\begin{array}{l}\text { Disciplina do } \\
\text { Plenário }\end{array}$ & $\begin{array}{l}\text { Disciplina da } \\
\text { Coalizão }\end{array}$ \\
\hline $\mathbf{1 9 8 7 - 1 9 9 1}$ & 66,59 & 54,24 & 87,26 \\
\hline $\mathbf{1 9 9 1 - 1 9 9 5}$ & 69,37 & 58,39 & 79,91 \\
\hline $\mathbf{1 9 9 5 - 1 9 9 9}$ & 71,33 & 51,50 & 86,50 \\
\hline $\mathbf{1 9 9 9 - 2 0 0 3}$ & 72,82 & 51,96 & 91,37 \\
\hline $\mathbf{2 0 0 3 - 2 0 0 7}$ & 67,50 & 68,93 & 87,92 \\
\hline
\end{tabular}

Fonte: Banco de Dados, Cebrap

Três aspectos institucionais ligados à comissão - a saber, a prerrogativa de o RelatorGeral emendar o orçamento, estimar a receita e sua autonomia decisória - tiveram um uso entre 1989 e 1993 e outro uso entre 1994 e 2006, o que configura "conversão institucional". A tabela 5.2 sistematiza os três aspectos, apresentados a seguir.

\footnotetext{
${ }^{110}$ Estabeleci a data de pertencimento partidário de cada deputado em 1 de novembro de cada ano para evitar problemas relacionados à migração de parlamentares. Escolhi novembro porque é logo após o período eleitoral e as migrações costumam acontecer até 5 de outubro em anos pré-eleitorais - se migração ocorreu, já terá sido captada. Apenas $6,56 \%$ dos parlamentares mudaram de partido no ano de pertencimento à comissão, média bastante inferior à média da Câmara dos Deputados, que é em torno de 25\% (Freitas 2008). Portanto, isto pouco influencia os dados apresentados. Do mesmo modo, o critério para definir se um partido pertence ou não à coalizão é 1/novembro de cada ano, porque o trabalho na CMO é bem mais intenso entre setembro e dezembro, e isso permite aferir a posição real dos partidos durante os trabalhos efetivos da comissão. Foram retiradas todas as votações em que o líder do governo não se posicionou; foram retiradas também todas as votações unânimes - se $91 \%$ dos parlamentares votaram da mesma forma, é considerada unânime e foram desconsideradas as votações inválidas, sem quorum. Cada parlamentar incluído precisa ter votado no mínimo cinco vezes em certo ano. Agradeço imensamente Andréa Freitas, do Cebrap, por fornecer os dados.
} 
Tabela 5.2: Uso de instituições relativas à organização da CMO, 1988-2006

\begin{tabular}{|c|c|c|}
\hline & 1988-1994 & 1995-2006 \\
\hline $\begin{array}{l}\text { Emendas do Relator- } \\
\text { Geral ao Orçamento }\end{array}$ & $\begin{array}{l}\text { *corrupção } \\
* \text { propositura de novos projetos }\end{array}$ & $\begin{array}{l}* \text { atendimento de demandas de } \\
\text { outros parlamentares }\end{array}$ \\
\hline $\begin{array}{l}\text { Relator-Geral estima } \\
\text { receitas }\end{array}$ & $\begin{array}{l}\text { *recursos para acolher demandas } \\
\text { corruptas } \\
\text { *recursos para acolher demandas } \\
\text { do relator-geral }\end{array}$ & $\begin{array}{l}\text { *recursos para acolher demandas } \\
\text { de outros parlamentares }\end{array}$ \\
\hline $\begin{array}{l}\text { Relator-Geral } \\
\text { centraliza poderes, } \\
\text { sem subcomissões } \\
\text { nem relatorias } \\
\text { setoriais fortes }\end{array}$ & $\begin{array}{l}\text { *Relator-Geral organiza acordos } \\
\text { com Executivo, mas não é } \\
\text { accountable a ele } \\
\text { * Relator-Geral não é agente do } \\
\text { Executivo: há pouca preocupação } \\
\text { com macroeconomia } \\
\text { * Falta de accountability: } \\
\text { Relator-Geral faz regras próprias } \\
\text { ou segue resoluções vagas e não } \\
\text { faz parecer preliminar detalhado }\end{array}$ & $\begin{array}{l}\text { * Relator-Geral é agente do } \\
\text { Executivo e accountable a ele } \\
\text { * Agente: Relator-Geral } \\
\text { preocupa-se bastante com } \\
\text { macroeconomia } \\
\text { * Accountability: Relator-Geral } \\
\text { faz parecer preliminar bastante } \\
\text { detalhado e segue resoluções }\end{array}$ \\
\hline
\end{tabular}

\section{1) Emendas de Relator-Geral ao orçamento}

As emendas de relator-geral foram, no período dos "anões do orçamento", um dos pilares do esquema de corrupção organizado por esses parlamentares. O ex-deputado federal João Alves de Almeida (PPR) acumulou, ilegalmente, US\$ 30,5 milhões entre 1989 e 1992 (Krieger et. al 1994, p. 26)). Junto com outros parlamentares de baixa estatura, Alves controlou a Comissão Mista de Orçamento nesse período, tendo sido relator-geral da lei orçamentária em 1990, e muito influente mesmo sem ocupar esse posto. Foi, sem dúvida, o líder dos "anões do orçamento".

João Alves, em diversos cargos importantes na Comissão Mista do Orçamento, "passou a decidir a inclusão de novas despesas no orçamento: construção de pontes, escolas, hospitais, verbas para programas sociais, recursos para grandes obras. Além disso, poderia incluir em seu relatório o aumento da dotação em despesas já previstas no projeto do Executivo. O deputado tornou-se dono de um concorrido balcão, freqüentado por políticos e empreiteiras" (Krieger et. al, 1994, p. 26).

Conforme o próprio parlamentar afirmou em depoimento à CPI, "o dinheiro do orçamento só saía se alguém descontingenciasse, e José Carlos Alves dos Santos, como Diretor do Orçamento no Executivo, era o intermediário" ${ }^{111}$. Afirmou também que José Carlos Alves dos Santos disse que recebia pedidos de parlamentares e de prefeitos que solicitavam o descontingenciamento de recursos destinados às suas respectivas regiões.

\footnotetext{
${ }^{111}$ Congresso Nacional, 1994 ( Volume II, depoimento tomado em 22/10/1993, p. 4).
} 
Conhecia também empresas particulares, através de comentários de parlamentares, que agilizavam a liberação de verbas e cobravam comissões que variavam de 5\% a $15 \%$.

Um dos principais recursos utilizados por Alves era a prerrogativa de propor emendas como relator-geral. Um exemplo é a emenda 955-6 de 1990 ${ }^{112}$. Foi aprovada como emenda de relator-geral "face à importância do subprojeto". Trata de infraestrutura urbana em Lauro de Freitas, município baiano. A emenda está no item "investimentos" do Ministério da Ação Social, um dos notoriamente corruptos da época (Krieger et. al, 1994, p. 109). O objetivo é "promover a recuperação e expansão da infra-estrutura básica de centros urbanos". Não há como provar que esta emenda, especificamente, foi utilizada para fins corruptos. Serve apenas para ilustrar a lógica da autonomia do relator-geral para incluir projetos - ligados ou não a atos corruptos - sem a concordância de outros parlamentares.

O relator-geral do Orçamento de 1992, Mansueto de Lavor, aparentava saber da associação das emendas de relator à corrupção. "Vali-me o mínimo possível da possibilidade de apresentar emendas de relator, e quando o fiz foi geralmente com o intuito de aprimorar tecnicamente o trabalho coletivo", escreveu. "A maioria foram emendas de adequação. Outras incluíram ou aumentaram valores com o objetivo único de dar racionalidade a um conjunto de ações de governo que permaneciam desarticuladas ou com hiatos, preponderantemente na área de infra-estrutura. Houve ainda as emendas que apresentei em resposta a apelos de destacadas autoridades, representando os genuínos interesses públicos de seus estados ou regiões."113

O número de emendas de relator-geral oscilava bastante ano a ano - em $1988^{114}$, 301; em 1993, 609 115 - e a natureza desse tipo de emenda começou a mudar em 1994. Naquele ano, de acordo com o colegiado que atuou como "relator-geral", as emendas de relator foram propostas "com vistas ao aperfeiçoamento e adequação da lei orçamentária, para aqueles casos em que as indicações recaíram sobre ações não perfeitamente contempladas por emendas existentes"116.

112 Congresso Nacional. Comissão Mista de Orçamento. Relação Geral dos Pareceres: Emendas Aprovadas. 13/12/1990, p. 3465.

${ }^{113}$ Congresso Nacional. Comissão Mista de Orçamento. Parecer Preliminar de 1992. Parecer sobre o Projeto de Lei n. 44, de $1992(\mathrm{CN})$, que "estima a receita e fixa a despesa da União para o exercício financeiro de 1993". Relator-Geral: Senador Mansueto de Lavor.

${ }_{114}$ Pesquisa do autor no Arquivo do Senado Federal, Brasília, 21/5/2008.

115 Comissão Mista de Orçamento. Sistema de Informações Orçamentárias. Relatório de Emendas Aprovadas. 26/3/1993, p. 19 -30.

${ }^{116}$ Congresso Nacional. Comissão Mista de Orçamento. Parecer Preliminar de 1994. Parecer Final da Comissão Mista de Orçamento sobre o Projeto de Lei n. 3 de 1994 (CN) de iniciativa do Poder Executivo que "estima a receita e fixa a despesa da União para o exercício financeiro de 1995". Autores: Gilberto 
O uso da emenda de relator-geral foi alterado no período de 1995 a 2006, quando essas emendas passaram a atender a demandas dispersas de parlamentares e bancadas estaduais. Em outras palavras, o relator-geral deixou de utilizar essas emendas para atingir objetivos próprios e passou a usá-las para equacionar as pressões inerentes a este poderoso cargo na Comissão Mista de Orçamento. O artigo 23 da Resolução 2/1995 proíbe as emendas de relator-geral de incluírem subprojetos novos à lei orçamentária. Não obstante isso, o relator-geral por vezes adota maneiras informais de atender aos pedidos de parlamentares e bancadas. Um exemplo é descrito por Sanches (1998, p. 9-10): “As 'Indicações de Bancada para Emendas de Relator', instituídas pelo Parecer Preliminar de 1996 e mantidas no Parecer Preliminar de 1997, contornam as restrições às emendas de Relator-Geral, São uma forma de violação aos limites quantitativos fixados pela Resolução n ${ }^{\circ}$ 2/95-CN para as emendas de bancada estadual”. As bancadas estaduais pressionam o Relator-Geral para que ele atenda suas demandas. Já que há um limite numérico para as emendas coletivas de bancada estadual, como vimos no capítulo anterior, o Relator-Geral incorpora parte dessas demandas em suas próprias emendas. Em 1997, foram apresentadas cerca de 200 emendas de RelatorGeral, das quais pelo menos $25 \%$ relativas à criação de novos subprojetos e subatividades".

Longe de significar atos unilaterais do relator-geral, as emendas de relator nos últimos anos têm sido um modo de atender às muitas demandas de parlamentares que não conseguiram influenciar o orçamento o suficiente a partir de suas emendas individuais e coletivas. Em 2007, por exemplo, o relator-geral incluiu um anexo de "metas e prioridades" que não constava da proposta enviada pelo Executivo. Uma notícia da época ${ }^{117}$. relata que "o anexo prevê gastos de $\mathrm{R} \$ 534$ milhões em obras que atenderão as bases eleitorais dos parlamentares. O valor entrou sob a denominação de "emendas do relator-geral". O deputado João Leão (PP) confirmou que a maioria das emendas do anexo veio de membros da comissão, que passaram a exigir do relator-geral mais espaços para verbas para seus projetos. Para autorizar o relator, a comissão fez novas concessões legais. Um parecer técnico da consultoria de Orçamento do Congresso

Miranda e diversos relatores-adjuntos, que são: senador Carlos Patrocínio; deputado Joao Faustino; deputado Roberto Balestra; deputado Vadão Gomes; deputado João Almeida; deputado Oswaldo Coelho; senador Ronan Tito. 2/12/1994.

117 "Contrabando no Orçamento dedica R\$ 534 milhões a emendas", Rubens Valente, Folha de S. Paulo, $25 / 2 / 2008$. 
havia advertido, em outubro de 2007, que o relator não tinha poderes para apresentar tais emendas como se fossem suas. Mas esse inconveniente foi ignorado" ${ }^{118}$.

\section{2) Estimativa de receitas pelo Relator-Geral}

O Legislativo brasileiro sistematicamente afirma que o Executivo subestima a receita a ser arrecadada no ano seguinte em seu projeto de lei orçamentária. Isto pode ocorrer por três motivos plausíveis. O primeiro é a incerteza inerente à condução econômica de um país. Bons ventos podem soprar e o crescimento econômico permitir maior arrecadação. Outro motivo é, em contexto inflacionário, o governo subestimar a inflação do ano seguinte de modo a não sinalizar negativamente para os demais agentes econômicos. Ao subestimar a inflação, os valores nominais da receita orçamentária serão abaixo do real. O terceiro motivo é o uso de metodologia equivocada pelo Executivo para aferir a receita esperada (Armstrong 1983) ${ }^{119}$.

No caso brasileiro, as mudanças estruturais na economia brasileira significaram que os parlamentares usaram, de 1988 a 1994, o segundo motivo para justificar o aumento de receitas e, de 1995 em diante, o terceiro motivo citado ${ }^{120}$. Uma ambiguidade constitucional é o mecanismo que permite a reestimativa de receitas pelo Congresso sem questionamento jurídico. A explicação clara de Tollini (2009, p. 6) vale ser reproduzida. "O Congresso Nacional usa subterfúgio controverso para burlar a Constituição e reestimar as receitas constantes dos projetos de lei orçamentária. O Congresso interpreta que a norma de 'correção de erros ou omissões aplica-se também à estimativa das receitas orçamentárias. Assim, utilizando-se do argumento de que as estimativas de receitas constantes dos projetos de lei orçamentária estariam 'erradas', o Congresso tem anualmente 'corrigido' as estimativas de receitas desde 1990. Como os "erros" encontrados têm sido invariavelmente receitas consideradas subestimadas ou ausentes, ao aprovar o autógrafo da lei orçamentária o Congresso introduz estimativa mais elevada das receitas, e apropria a diferença para financiar novas despesas".

\footnotetext{
${ }^{118}$ Podemos imaginar que se houvesse um cargo na Comissão Mista de Orçamento tão poderoso quanto o presidente da comissão orçamentária no Peru - que decide, sozinho, quais emendas parlamentares são aprovadas (Carranza Chávez e Valderrama 2009, p. 202) - a pressão seria ainda maior e soluções informais como este uso da emenda de relator-geral seriam comuns.

${ }^{119}$ Citado por Couture e Imbeau (2009).

${ }^{120}$ De acordo com Couture e Imbeau (2009. p. 56), o Executivo poderia ter razões também para superestimar as receitas a serem arrecadadas. Isto serviria para mostrar um déficit menor ou para justificar aumento de gastos em anos eleitorais. Para uma análise dessas e outras estratégias nos Estados Unidos, ver Block (2008).
} 
No período em que a comissão era controlada pelos "anões do orçamento", essas despesas financiadas por acréscimo na estimativa de receitas eram de natureza corrupta $^{121}$ ou, no mínimo, "pessoal". Em outras palavras, não se tratava de uma negociação ampla para atender a demandas diversas, mas sim de despesas que interessavam especificamente ao cartel corrupto que controlava a comissão. Dois exemplos indicam esse uso, ambos com o deputado João Alves.

Em 1990, quando era relator-geral, Alves propôs um acréscimo ao parecer preliminar aprovado pela Comissão Mista de Orçamento, "incluindo, como acréscimo aos programas já existentes, as seguintes dotações, programadas à conta da reestimativa da receita: i) apoio técnico para secretarias municipais de saúde pelo INAMPS; ii) apoio à habitação popular, através do Ministério da Ação Social ; iii) assentamento de trabalhadores rurais, através do Incra"122 (grifo meu). Utilizava o mesmo artifício para financiar suas emendas de relator-geral, como a de número 956-4 em 1990. Esta emenda tratava de investimento no "aproveitamento hidroagrícola de Irece, perímetro de irrigação Paramirim", constava do Ministério da Agricultra e Reforma Agrária e seria financiada por reestimativa de receitas ${ }^{123}$.

A justificativa mais comum para explicar a necessidade de reestimar a receita era relacionada à hiperinflação do periodo. No parecer preliminar de 1991, o relatorgeral Ricardo Fiúza reclamou de "desvios entre a previsão de receita e despesa e sua execução pela ausência de indexação nos valores incluídos no orçamento. O governo é forçado a admitir taxas irreais de inflação para não sinalizar indevidamente aos agentes econômicos. $O$ resultado é um orçamento subestimado, que não expressa o programa de governo nem as prioridades nacionais. (...). A partir de informações novas a respeito da política econômica externa para 1992, que vieram à luz posteriormente à elaboração da proposta pelo Executivo, e após considerar o impacto financeiro de medidas recentes em matéria tributária e de cobrança e arrecadação de rendas da União, pude estimar um aumento dos ingressos, que destinei ao financiamento de ações prioritárias"124 (grifo meu).

\footnotetext{
121 Um ato corrupto implica o abuso de poder político para fins privados, definição adotada por organizações como o Banco Mundial e a Transparência Internacional (Transparency International, 2007, p. xxi).

${ }_{122}$ Ofício informal do Relator-Geral em 1990. Deputado João Alves, 17/12/1990.

123 Congresso Nacional. Comissão Mista de Orçamento. Relação Geral dos Pareceres: Emendas Aprovadas. 13/12/1990, p. 3466.

${ }^{124}$ Congresso Nacional. Comissão Mista de Orçamento. Parecer Preliminar de 1991. Parecer Final sobre o projeto de lei n. 26 de 1991-CN que "estima a receita e fixa a despesa da União para o exercício financeiro de 1992”. Relator-Geral: Ricardo Fiúza. 17/12/1991.
} 
De 1994 em diante, o Congresso institucionalizou o mecanismo da "correção de erros e omissões" através da Resolução 2/1995, facilitando (e legitimando) a reestimativa de receitas. Não há pistas de que as reestimativas têm servido para financiar esquemas específicos de corrupção ou projetos pessoais dos relatores-gerais do orçamento no período recente. Têm a função, atualmente, de permitir que o relator-geral inclua despesas pensadas por outros parlamentares, algo que tem exigido certa criatividade dos ocupantes deste cargo. Em 2008, por exemplo, o relator-geral Delcídio Amaral (PT) propôs até mesmo incluir a possibilidade de remanejar recursos do PAC (Programa de Aceleração do Crescimento), uma das principais bandeiras do Executivo, para atender emendas parlamentares ${ }^{125}$.

A justificativa utilizada pelos relatores-gerais para reestimar a receita indicada pelo Executivo é de ordem metodológica, exemplificada pela afirmação de Carlos Bezerra, relator-geral em 1996: "Nossa primeira preocupação ao proceder a análise da receita foi a de não deixar que se repetisse o erro cometido na proposta orçamentária de 1995 para 1996. A mensagem do Executivo pouco esclareceu quanto aos procedimentos metodológicos usados para estimar receitas"

A principal consequiência da reestimativa de receitas pelos parlamentares é a "perda de realismo da lei orçamentária, que passa a conter despesas para as quais não haverão receitas suficientes. Por conta das reestimativas de receitas sempre excessivamente otimistas, todo início de ano o governo federal tem imposto contingenciamentos gigantescos" (Tollini 2009, p. 7). Não há notícia recente de que o secretário do Tesouro Nacional e o secretário do Orçamento Federal tenham se agredido publicamente por causa disso.

\section{3) Centralização de poderes no Relator-Geral e sua relação com o Executivo}

Vale agora analisar a centralização de poderes orçamentários na figura do Relator-Geral e a relação deste com o Executivo. Tanto de 1988 a 1993 quanto no período posterior, o Relator-Geral do orçamento tem amplos poderes decisórios, sem subcomissões nem relatorias setoriais fortes dentro da Comissão Mista de Orçamento. Mas o uso deste poder nos dois períodos é bastante diferente.

\footnotetext{
125 "Relatório do Orçamento abre brecha para o PAC", Fernanda Odilla, Folha de S. Paulo, 17/10/2008.

${ }^{126}$ Congresso Nacional. Comissão Mista de Orçamento. Parecer Preliminar de 1996. Parecer Preliminar sobre o Projeto de Lei n. 8, 1996-CN, que estima a receita e fixa a despesa da União para o exercício financeiro de 1997. Relator-Geral: Carlos Bezerra. 10/10/1996.
} 
De 1988 a 1993, o Relator-Geral era o principal responsável por organizar acordos com o Executivo, mas não era accountable a ele. Não pode ser considerado um agente do Executivo por não exibir grande preocupação com aspectos macroeconômicos. Não escreve seu parecer preliminar de modo detalhado, faz regras próprias ou segue resoluções congressuais bastante vagas. Em contraste, de 1994 em diante, o RelatorGeral é um agente do Executivo e accountable a ele ${ }^{127}$. Escreve pareceres preliminares detalhados, revelando interesse e preocupação com a macroeconomia. Além disso, segue os principais pontos das resoluções congressuais que regulamentam a tramitação legislativa do orçamento.

A “conversão institucional” configura-se mesmo com algumas mudanças formais sugeridas pela Resolução 2/1995 no sentido de diminuir o poder do relatorgeral. Sugeriu-se a criação de subcomissões permanentes e, assim, um novo papel para o relator-geral, que se tornaria um coordenador dos relatores setoriais. No entanto,é importantíssimo frisar que essas mudanças formais não foram adotadas na prática. $\mathrm{O}$ principal motivo para isso foi a redação vaga e ambígua da Resolução 2/1995, que permitiu a circumvenção das novas normas com facilidade.

Quanto às subcomissões permanentes da Comissão Mista de Orçamento, elas nunca foram instituídas a contento, apesar de previstas na resolução de 1995. De acordo com a justificativa do projeto de resolução congressual 5/2000, proposto pela Mesa Diretora do Congresso Nacional, propunha-se a "extinção das subcomissões permanentes, que existem no texto da Resolução 2/1995, mas não funcionaram nos dois últimos exercícios" ${ }^{2128}$. Diversos consultores orçamentários do Congresso têm testemunho semelhante. Segundo Macedo e Nerosky (2000, p. 2), “a inexistência de subcomissões temáticas prejudica o acompanhamento e a fiscalização financeira da execução orçamentaria”. Do mesmo modo, o consultor Helio Tollini afirma que as subcomissões não funcionam por falta de participação e interesse dos parlamentares, que alegavam não ter tempo hábil de estarem presentes em todas as etapas da tramitação do orçamento onde eram

\footnotetext{
${ }^{127}$ A tentativa de o Executivo interferir na parte legislativa do processo orçamentário não é novidade em presidencialismos. No Equador, por exemplo, entre 1979 e 1997, a comissão orçamentária analisava o projeto de orçamento enviado pelo Executivo. As emendas parlamentares necessitavam da aprovação do Plenario de Las Comisiones Legislativas (PCL) do Congresso, um conselho composto por 35 parlamentares - tipicamente dos maiores partidos. A necessidade de aprovação do PCL beneficiava esses partidos, que negociavam diretamente com o Executivo suas alocações orçamentárias (Acosta et. al 2009, p. 135-137).

${ }_{128}$ Justificativa do Projeto de Resolução 5/2000-CN, que dispõe sobre a Comissão Mista de Orçamento. $8 / 6 / 2000$.
} 
requeridos ${ }^{129}$. Portanto, se a existência formal das subcomissões a eles interessava como resposta ao escândalo dos "anões do orçamento", a delegação de poder ao relator-geral interessava aos parlamentares na prática.

Sobre o papel do relator-geral como mero organizador dos relatórios setoriais, Sanches (1998, p. 10): observa que "na prática, o relator-geral continua concentrando grande poder às expensas das relatorias setoriais. O principal motivo são as normas do parecer preliminar que têm reservado ao Relator-Geral os recursos derivados de cortes nas despesas de custeio, dos erros de alocação (como, por exemplo, nas transferências legais, reservas de contingência e sentenças judiciais) e dos adicionais de receita (novas ou reestimadas) em relação às previsões do Executivo. Neste último exercício, enquanto as relatorias setoriais só conseguiram mobilizar algo como $\mathrm{R} \$ 1$ bilhão com base no que lhes autorizava o parecer preliminar, a Relatoria-Geral trabalhou com R $\$ 3,3$ bilhões, dos quais $\mathrm{R} \$ 1,2$ bilhão por ela alocados diretamente e $\mathrm{R} \$ 2,1$ bilhões disponibilizados às Relatorias Setoriais, para atender às emendas individuais e parcialmente às emendas coletivas" $^{130}$.

Assim, nota-se que o relator-geral ocupa um papel crucial no processo de apreciação do orçamento no Congresso. Cabe a ele elaborar parecer preliminar ao projeto de lei orçamentário, a ser votado no plenário da comissão, estabelecendo critérios adicionais aos fixados pela Constituição e pela Lei de Diretrizes Orçamentárias (LDO) à intervenção dos parlamentares no projeto de orçamento. O parecer preliminar disciplina questões como dotação global de cada função, subfunção, órgão ou área temática. Também trata de condições, restrições e limites para o remanejamento e o cancelamento de dotações e dos limites de valores para as emendas individuais. Além disso, examina as conjunturas macroeconômica e fiscal do país, a adequação da proposta orçamentário com o Plano Plurianual (PPA) e a LDO, analisa as estimativas de receita e estabelece critérios de preferência para as emendas que contemplem ações definidas como prioritárias na LDO, entre outras atribuições ${ }^{131}$. A seção a seguir detalha como o Relator-Geral, ao se preocupar com aspectos macroeconômicos, torna-se um agente do Executivo.

\footnotetext{
${ }^{129}$ Entrevista com o consultor de orçamento Helio Tollini, Câmara dos Deputados, Brasília, Janeiro de 2009.

${ }^{130}$ Em suas sugestões para a formulação da Resolução 2/1995, a assessoria técnica do Congresso Nacional relatou situação semelhante. Esses números devem ser contextualizados considerando o tamanho do orçamento executado pelo governo em 1998: cerca de $\mathrm{R} \$ 624$ bilhões (Figueiredo e Limongi 2008, p. 35).

${ }^{131}$ Ver Lima e Miranda (2006, p. 338-339).
} 


\section{4) Relator-Geral como agente do Executivo}

Durante o período dos "anões do orçamento", a relação entre o Executivo e a Comissão Mista de Orçamento não era próxima. Os presidentes e relatores-gerais da comissão à época estavam longe de serem parlamentares com boa relação com o Executivo. Diversos investigados pela CPI do Orçamento de 1993-1994 relatam como acordos ad hoc entre integrantes da CMO e membros do Executivo foram aventados. De acordo com o burocrata corrupto José Carlos Alves dos Santos, houve, provavelmente em 1992, um acordo entre o Departamento de Orçamento da União (comandado por José Carlos), Pedro Parente e seus superiores no Ministério da Economia ${ }^{132}$, com conhecimento do ministro Marcílio Marques Moreira e do presidente Fernando Collor, segundo a qual seriam mantidos entendimentos com o núcleo da Comissão Mista de Orçamento para que já constassem da proposta do Executivo dotações que atendessem a esses parlamentares. Era uma negociação informal entre o Ministério da Economia, o Executivo e o Congresso ${ }^{133}$.

Na mesma CPI, o parlamentar José Geraldo relatou uma reunião em 1990 na casa do deputado João Alves com Pedro Parente, José Carlos Alves dos Santos, Ronaldo Aragão, Genebaldo Correia e Cid Carvalho. Nesse encontro, Alves revelou os limites de cancelamento para atendimento de emendas que pretendia propor em seu parecer preliminar. Esses limites seriam de 1\% de cancelamento para "outras despesas correntes" e $2 \%$ para investimentos, inversões financeiras e outras despesas de capital. Quanto menores os limites de cancelamento, menos liberdade os parlamentares teriam para mudar a proposta do Executivo. Se assim fosse, o Congresso praticamente não poderia alterar o Orçamento, algo que agradaria ao Executivo. Não obstante os pedidos que recebeu em contrário, Alves ficou irredutível. Não teve sucesso em aprovar essa preferência. Posteriormente, os limites foram alterados para 3\% para outras despesas correntes, $15 \%$ para investimentos e inversões financeiras e outras despesas de capital e

\footnotetext{
132 De 1990 a 1992, o que hoje conhecemos como Ministério da Fazenda se chamava Ministério da Economia, Fazenda e Planejamento.

133 Relatório Final da CPI do Orçamento, 1994, Depoimento de José Carlos Alves dos Santos, 20/10/1993, p. 56-57.
} 
$25 \%$ para investimentos, inversões financeiras e outras despesas de capital ${ }^{134}$. Assim, o Congresso teve muita liberdade para mudar a proposta orçamentária do Executivo.

Em contraste, de 1994 em diante o relator-geral do orçamento parecia ter estreita relação com o Executivo. Há um cuidado especial na escolha do relator-geral do Orçamento desde o governo Fernando Henrique Cardoso. Como regra geral, eles adotam um comportamento "chapa-branca". Não fazem nenhuma alteração sensível no orçamento sem negociar primeiro com o Ministro da Fazenda ou do Planejamento. O relator-geral atua fortemente como representante do Executivo. Várias alterações que teriam sido importantes para o Legislativo não foram adotadas durante esse período porque o ministro do Planejamento barrou ${ }^{135}$.

O principal exemplo da ação do Relator-Geral como agente do Executivo é sua progressiva preocupação com aspectos macroeconômicos, típicos da jurisdição do Executivo. De 1988 a 1993, os relatores-gerais pouco se importavam com as condições econômicas do país, procurando apenas encontrar receitas para atender às demandas dos parlamentares. É notável o exemplo do relator-geral Eraldo Tinoco em 1989. Havia dois grandes problemas a resolver naquele ano: o orçamento do Judiciário e o acolhimento de emendas parlamentares. Tinoco optou por estabelecer uma programação orçamentária "especial”, com recursos decorrentes do excesso de arrecadação tributária ${ }^{136}$. Esse dinheiro viria da "economia decorrente das medidas que o novo governo do president Fernando Collor certamente tomará, tanto no campo fiscal quanto no administrativo, principalmente nas questões cruciais de combate à inflação, de redução dos gastos públicos e de alterações na política relativa à dívida pública. Haverá também alterações no comportamento das taxas de juros e da estrutura da dívida, alongamento do perfil da dívida, substituição de credores etc." ${ }^{137}$. O otimismo de Tinoco, completamente dissociado da realidade do novo governo, não se concretizou.

No periodo mais recente, a partir de 1994, o relator-geral do Orçamento passou a se preocupar com aspectos macroeconômicos de modo realista, consoante com orientações do Executivo. Um jornal relata como, em 2008, o senador Delcídio Amaral (PT), relator do Orçamento naquele ano, preocupava-se com a crise internacional e

\footnotetext{
${ }^{134}$ Relatório Final da CPI do Orçamento, 1994, Depoimento de José Geraldo, Novembro de 1993, p. 27 28.

${ }^{135}$ Entrevista com Rita de Cássia Leal Fonseca dos Santos, consultora de Orçamento do Senado Federal, Brasília, Maio de 2008.

${ }^{136}$ Ver seção sobre reestimativa de receitas.

137 Congresso Nacional. Comissão Mista de Orçamento. Parecer Prelininar de 1989. Projeto de Lei Orçamentária para 1990. Adendo ao Relatório Preliminar do relator-geral Eraldo Tinoco.
} 
adotava um "tom de austeridade" em seu parecer preliminar: "Em 70 páginas, o documento vai sugerir que o governo mantenha o superávit primário em 4,3\% do PIB, em vez de reduzi-lo para 3,8\%, como cogitado. Também haverá menção a cortes de custeio, investimentos fora do PAC e emendas" ${ }^{138}$. Dois meses depois, confirmou-se a intervenção do relator-geral no sentido de cortar gastos, ao contrário do que poderíamos esperar se ele não tivesse relação tão estreita com o Executivo: "Em seu parecer, Amaral afirma que os parâmetros que orientaram a elaboração do projeto orçamentário baseavam-se em cenário otimista que se modificou à medida que se tornaram mais claros os impactos da desaceleração da economia mundial sobre a atividade interna. Assim, a proposta orçamentária, que chegou ao Congresso com gastos globais de $\mathrm{R} \$$ 1,664 trilhão, foi ajustada para R \$ 1,658 trilhão" "139. Enorme diferença em relação aos tempos de Eraldo Tinoco, que confiava na austeridade e competência do Executivo para gerar receitas que financiassem os gastos incluídos no orçamento durante sua tramitação parlamentar.

\section{1,5) Accountability do Relator-Geral a seus pares e às regras congressuais}

O segundo aspecto a considerar é a accountability do relator-geral em relação a seus pares e às regras congressuais que definem a tramitação legislativa do Orçamento. De 1988 a 1993, esta accountability praticamente não existia. Os relatores-gerais seguiam resoluções congressuais extremamente vagas - isto quando não havia a possibilidade de eles mesmos fazerem e interpretarem suas próprias regras. Em depoimento à CPI do Orçamento de 1993-1994, Mansueto de Lavor reclamou de "dificuldades internas à comissão, como a falta de adequados instrumentos normativos e legais que permitam superar o dilema do rodízio e da experiência dos membros da comissão e a indefinição do perfil dos relatores parciais, dos relatores setoriais e, sobretudo, do relator-geral" ${ }^{\prime 140}$.

Isto fica claro observando um memorando do relator-geral João Alves em 1990. O parlamentar resolveu, unilateralmente, que criaria regras para regulamentar questões na Comissão Mista de Orçamento: "Esta relatoria, não tendo havido objeção do plenário, adotou previdências que têm orientado o processo de tramitação legislativa das matérias orçamentárias, até que seja aprovado o novo regimento comum. Esta relatoria,

\footnotetext{
138 "Novos Tempos", Painel, Folha de S. Paulo, 11/10/2008

139 "Comissão do Congresso aprova relatório do Orçamento de 2009”, Agência Senado, 16/12/2008.

${ }^{140}$ Relatório Final da CPI do Orçamento, 1994, Depoimento de Mansueto de Lavor, 4/1/1994, p. 138.
} 
não havendo objeção do plenário, e até que seja votado o novo regimento comum, resolve (grifo dele) estabelecer para o presente período legislativo os seguintes procedimentos e calendário para apreciação do projeto de lei orçamentária para 1991, do projeto de Lei do Plano Plurianual para 1991-1995, bem como de projetos de créditos adicionais" $" 141$.

Memorandos informais não eram incomuns à época dos "anões do orçamento". Em depoimento à CPI de 1993-1994, João Alves confessou ter recebido, em maio de 1989, um ofício assinado pelo então presidente da comissão, Cid Carvalho, designandoo para "coordenar e encaminhar, junto aos respectivos ministérios, os assuntos relativos às subvenções sociais do interesse da Comissão Mista de Orçamento". Alves encaminhava aos setores competentes do ministério a relação das entidades designadas para serem beneficiadas com subvenções, para a posterior liberação dos recursos ${ }^{142}$.

A Resolução 1/1991, a primeira do período democrático recente, trouxe algum avanço. Instituiu que a Comissão Mista de Orçamento seria composta por 120 membros, sendo 90 deputados e 30 senadores, de acordo com a proporção das bancadas partidárias. Resoluções subseqüentes diminuíram o número de integrantes para 84, 63 deputados e 21 senadores. Talvez a medida mais importante desta resolução tenha sido a renovação anual de, no mínimo, 50\% dos membros, sendo proibida a permanência de qualquer membro por mais de dois anos consecutivos ${ }^{143}$. Outras medidas da Resolução 1/1991 permanecem até hoje: i) a alternância anual entre membros da Câmara dos Deputados e do Senado Federal para exercer cargos de presidente, vice-presidente, relator da Lei de Diretrizes Orçamentárias (LDO), relator da Lei Orçamentária Anual (LOA) e demais relatores; ii) o presidente da comissão indica o relator da LDO, o relator da LOA e os demais relatores ${ }^{144}$; iii) o relator-geral da LOA apresenta parecer preliminar sobre proposta do Executivo que, depois de aprovado pelo plenário da CMO, estabelece parâmetros que relatores setoriais obrigatoriamente devem seguir; iv) o parecer da CMO sobre emendas ao orçamento será conclusivo, salvo requerimento assinado por 1/10 dos congressistas para que a matéria seja discutida em plenário.

\footnotetext{
${ }^{141}$ Regras fixadas pelo Relator-Geral da Comissão Mista de Orçamento em 1990. Pesquisa do Autor no arquivo do Senado Federal, Maio de 2008.

${ }_{142}$ Relatório Final da CPI do Orçamento, 1994, Depoimento de João Alves Filho, 8/1/1994, p. 209.

143 Como ficou claro no caso dos "anões do orçamento", a permanência de um parlamentar na CMO é associada à corrupção, não à possível especialização benigna do representante em assuntos orçamentários. ${ }^{144}$ Soares (2007, p. 16) observa que "oficialmente, é o presidente da CMO quem designa um relatorgeral, relator da receita e relatores setoriais (...). Na prática, essa designação é feita em rodízio, depois de um acordo entre os líderes partidários, respeitando a alternância entre senadores e deputados, prevista nas normas da comissão, e o impedimento de reeleição e continuidade no cargo".
} 
Por sua vez, a Resolução 1/1993 disciplina que cada membro da comissão pode apresentar, no máximo, 50 emendas individuais. (O capítulo anterior analisa este ponto detalhadamente.) Quanto mais detalhadas as resoluções, mais accountable se tornam os relatores-gerais a seus pares. Após o escândalo dos "anões do orçamento", a preocupação dos integrantes da comissão orçamentária em realizar um trabalho menos obscuro era explícita. O colegiado que atuou como relatoria-geral em 1994, por exemplo, afirmou: "Fizemos questão de dar total transparência às ações e decisões adotadas no exercício desta relatoria. As decisões mais significativas foram compartilhadas entre o relator-geral e os sete relatores adjuntos, assegurando, ainda, aos partidos não representados no colegiado o acompanhamento dos trabalhos da relatoria. Além disso, o procedimento adotado de permitir ao parlamentar a escolha de suas emendas prioritárias evitou surpresas no conhecimento dos termos deste parecer, o que antes só ocorria na véspera de sua deliberação"145.

No período recente, vale alertar que ainda há espaço para que relatores-gerais e outros ocupantes de cargos relevantes se aproveitem de relativa autonomia, mesmo dentro das regras congressuais. De acordo com um jornal, "o relator-geral do orçamento de 2007, senador Valdir Raupp (PMDB), e o novo líder do governo no Senado, Romero Jucá (PMDB), amealharam R\$ 934 milhões das verbas de investimento federal do próximo ano para seus Estados - quase 10 vezes mais do que o inicialmente reservado pelo governo na proposta enviada ao Congresso, em agosto passado. $\mathrm{O}$ valor previsto na lei orçamentária para Roraima e Rondônia é tão desproporcional ao seu tamanho que quase empata com o de São Paulo, que tem uma população 20 vezes maior e foi contemplado com R\$ 1,07 bilhão"146. A execução dessas verbas depende, é claro, da proximidade dos parlamentares com o Executivo ${ }^{147}$. Conclui-se, portanto, que a coalizão liderada pelo Executivo tem, desde 1995, ampla influência para determinar os rumos da tramitação legislativa do orçamento.

\footnotetext{
145 Congresso Nacional. Comissão Mista de Orçamento. Parecer Preliminar de 1994. Parecer Final da Comissão Mista de Orçamento sobre o Projeto de Lei n. 3 de 1994 (CN) de iniciativa do Poder Executivo que "estima a receita e fixa a despesa da União para o exercício financeiro de 1995". Autores: Gilberto Miranda e diversos relatores-adjuntos, que são: senador Carlos Patrocínio; deputado Joao Faustino; deputado Roberto Balestra; deputado Vadão Gomes; deputado João Almeida; deputado Oswaldo Coelho; senador Ronan Tito. 2 de dezembro de 1994.

146 "Influência de parlamentares eleva fatia de ex-territórios no Orçamento", Sérgio Gobetti, O Estado de S. Paulo, 26/12/2006.

${ }^{147}$ Afinal, segundo Figueiredo e Limongi (2008, p. 104, grifo meu), “a execução das emendas individuais é pautada por critérios políticos. As emendas dos deputados filiados a partidos da coalizão do governo têm maiores chances de serem executadas do que as dos demais parlamentares. Contudo, parte das emendas de deputados da oposição também é executada e parte das emendas dos parlamentares que votam com o governo não é executada".
} 
Para que o fenômeno da "conversão institucional" fique mais claro, é importante retomar um raciocínio. A conversão se configura quando regras formais permanecem as mesmas de um período para o outro, mas são interpretadas e implementadas de uma nova maneira. Esta seção analisou como os "anões do orçamento" e a coalizão liderada pelo Executivo utilizaram, de modo bastante diferente, o mesmo poder concentrado no relator-geral da Comissão Mista de Orçamento. Não houve a remoção de regras antigas, nem a desobediência a regras antigas; houve um impacto diferenciado das mesmas regras referentes aos poderes do relator-geral, e não houve a introdução de novas regras realmente relevantes para este cargo no período analisado. Isto satisfaz as condições de Mahoney e Thelen (2009) para que a conversão institucional se caracterize ${ }^{148}$.

\section{(2) Escolhas institucionais na Comissão Mista de Orçamento}

Esta seção analisa o segundo paradoxo relativo à Comissão Mista de Orçamento: por que a comissão não foi descentralizada em 1995, quando havia forte pressão da CPI dos "anões do orçamento" para isso, mas em 2006 ocorreu a descentralização parcial? Esta decisão é paradoxal por ser contra os interesses de curto prazo da coalizão. Afinal, quanto mais descentralizada a Comissão Mista de Orçamento, mais custoso é controlar seus principais postos de poder. Isto pode ser explicado pela bem-sucedida estratégia do entrepreneur Ricardo Barros, da oposição, em 2006. Barros conseguiu driblar o controle da agenda da coalizão através de sucessivas chantagens e negociações. Concedeu em alguns pontos - desistiu, por exemplo, de fazer a oposição indicar um Relator da Receita - e manteve-se firme em outros ${ }^{149}$.

O paradoxo pode ser explicado através de uma abordagem analítica que considera a interação entre idéias e interesses - tanto de curto prazo quanto de longo prazo - durante critical junctures. Utilizo, aqui, a mesma explicação teórica proposta no quarto capítulo, adaptada para estudar a organização da Comissão Mista de Orçamento. As idéias dos parlamentares a respeito da organização da Comissão Mista de Orçamento podem ser consoantes ou não com os interesses deles. Seguindo Schickler (2001, p. 5), cinco tipos de interesses dos parlamentares motivam o desenho de instituições

\footnotetext{
${ }^{148}$ Ainda utilizado o framework desses autores, vale notar que a coalizão após 1994 pode ser considerada como um change-agent de natureza "simbionte mutualística", ou seja, que se aproveita de instituições que não desenharam sem desobedecê-las ou tentar destrui-las, mas utilizando-nas a favor de seus interesses.

${ }^{149}$ O próximo capítulo mostra que o senador Antônio Carlos Magalhães quase conseguiu o mesmo em relação ao Orçamento Impositivo, mas os stakes eram muito maiores: tratava-se da obrigatoriedade de o Executivo implementar o orçamento alterado pelo Legislativo.
} 
legislativas. Três têm especial relevância neste capítulo. São eles: i) interesse no acesso a postos de poder institucional; ii) interesses relativos ao pertencimento à coalizão ou oposição e iii) interesse no Legislativo como ator coletivo ${ }^{150}$.

As idéias dos parlamentares podem ser contrárias a seus interesses de curto prazo, configurando o que chamo de "preferências deslocadas" dos atores. Trata-se, por exemplo, de um ator que tem interesses A e B para apoiar a instituição X (os interesses podem ser no acesso a um posto institucional e no pertencimento à coalizão; a instituição pode ser "CMO completamente centralizada"), mas defende o fim (ou descentralização parcial) desta instituição. Essas idéias inserem-se em um contexto cuja agenda é controlada por um grupo politico. No caso deste trabalho, dois grupos disputam esse controle: a coalizão liderada pelo Executivo e a oposição. Nas duas critical junctures aqui analisadas, a coalizão obteve amplo controle da agenda durante a primeira (1994-1995) e dividiu, com Ricardo Barros, um entrepreneur da oposição, o controle da agenda durante a segunda critical juncture (2005-2006).

Os quatro pontos empíricos a serem analisados nesta seção são: 1) o poder do Relator-Geral da Comissão Mista de Orçamento para emendar o orçamento; 2) o poder do Relator-Geral para estimar a receita; 3 ) a existência da CMO (ou poder orçamentário para subcomissões e comissões temáticas) e 4) a força dos relatores setoriais vis-à-vis o relator-geral.

Cada um desses itens pode ser compreendido em um continuum que engloba da centralização completa à descentralização completa do processo ${ }^{151}$. Podemos imaginar, em uma das pontas, um processo orçamentário no qual o relator-geral é o único ator com prerrogativa de emendar o orçamento; o relator-geral estima as despesas e receitas sem físcalização de outros membros da comissão; a comissão orçamentária é a única responsável pelo orçamento e nela não há subcomissões institucionalizadas; não há relatores setoriais para auxiliar o relator-geral. Na outra ponta, imaginamos um processo orçamentário no qual não há um relator-geral, mas apenas relatores setoriais, e tanto a

\footnotetext{
${ }^{150}$ Os outros interesses parlamentares considerados pelo autor são os relativos a políticas públicas e à reeleição.

${ }^{151}$ Os quatro itens tratam dos pontos fundamentais da organização da etapa legislativa do processo orçamentário. Outros pontos, como o rodízio de membros da Comissão Mista de Orçamento e o rodízio de relatores setoriais, também são relevantes e ligados à spercepções sobre corrupção orçamentária. No entanto, optei por deixá-los de fora da análise por não considerar que têm ligações claras com os interesses de curto prazo considerados neste trabalho. Há um forte argumento no sentido de que quanto mais um parlamentar permanece na comissão orçamentária, melhores são suas chances de reeleição. No entanto, isto já está abordado na discussão sobre emendas individuais e reeleição realizadas no capítulo anterior. O cargo na comissão orçamentária serveria apenas como o mecanismo através do qual um parlamentar tem mais poder de barganha para fazer valer suas preferências orçamentárias.
} 
despesa quanto a receita são estimadas por comissões temáticas. A tabela 5.3 sistematiza essas escolhas possíveis.

Tabela 5.3: Escolhas possíveis relativas à organização legislativa do processo orçamentário

\begin{tabular}{|c|c|c|c|c|}
\hline & $\begin{array}{l}\text { Centralização } \\
\text { completa }\end{array}$ & Centralização parcial & $\begin{array}{l}\text { Descentralizaçã } \\
\text { o parcial }\end{array}$ & $\begin{array}{l}\text { Descentralização } \\
\text { completa }\end{array}$ \\
\hline $\begin{array}{l}\text { 1) Poder do } \\
\text { Relator-Geral para } \\
\text { emendar o } \\
\text { orçamento }\end{array}$ & $\begin{array}{l}\text { Relator-Geral é o } \\
\text { único a emendar } \\
\text { orçamento }\end{array}$ & $\begin{array}{l}\text { Relator-Geral pode } \\
\text { emendar orçamento sem } \\
\text { limites, assim como outros } \\
\text { parlamentares (1988- } \\
\text { 1994) }\end{array}$ & $\begin{array}{l}\text { Relator-Geral } \\
\text { pode emendar o } \\
\text { orçamento, com } \\
\text { limites (1995-) }\end{array}$ & $\begin{array}{l}\text { Relator-Geral não } \\
\text { pode emendar o } \\
\text { orçamento }\end{array}$ \\
\hline $\begin{array}{l}\text { 2) Poder do } \\
\text { Relator-Geral para } \\
\text { estimar a Receita }\end{array}$ & $\begin{array}{l}\text { Relator-Geral } \\
\text { estima receita, sem } \\
\text { fiscalização (1988- } \\
\text { 2001) }\end{array}$ & $\begin{array}{l}\text { * Relator-Geral estima } \\
\text { receita, auxiliado por } \\
\text { subcomissão específica } \\
(2001-2006) ; \\
* \text { Há Relator da Receita } \\
\text { indicado de acordo com a } \\
\text { proporcionalidade } \\
\text { partidária (2006-) }\end{array}$ & $\begin{array}{l}\text { Há Relator da } \\
\text { Receita indicado } \\
\text { pela oposição }\end{array}$ & $\begin{array}{l}\text { Receita é estimada } \\
\text { por comissões } \\
\text { temáticas }\end{array}$ \\
\hline $\begin{array}{l}\text { 3) Existência da } \\
\text { Comissão } \\
\text { Orçamentária e } \\
\text { institucionalização } \\
\text { de subcomissões }\end{array}$ & $\begin{array}{l}\text { Uma única } \\
\text { comissão cuida do } \\
\text { orçamento, sem } \\
\text { subcomissões } \\
(1988-2001)\end{array}$ & $\begin{array}{l}\text { Uma única comissão } \\
\text { cuida do orçamento, mas } \\
\text { há subcomissões mais ou } \\
\text { menos institucionalizadas } \\
\text { (2001-) }\end{array}$ & $\begin{array}{l}\text { Comissão } \\
\text { orçamentária } \\
\text { cuida do } \\
\text { orçamento, junto } \\
\text { com comissões } \\
\text { temáticas }\end{array}$ & $\begin{array}{l}\text { Comissões } \\
\text { temáticas cuidam } \\
\text { do orçamento }\end{array}$ \\
\hline $\begin{array}{l}\text { 4) Relação Relator- } \\
\text { Geral e Relatores } \\
\text { Setoriais }\end{array}$ & $\begin{array}{l}\text { Não há relatores } \\
\text { setoriais. Relator- } \\
\text { Geral trabalha } \\
\text { sozinho }\end{array}$ & $\begin{array}{l}\text { Relator-geral trabalha com } \\
\text { relatores setoriais pouco } \\
\text { poderosos }(1988-2006)\end{array}$ & $\begin{array}{l}\text { Relator-Geral } \\
\text { trabalha com } \\
\text { relatores setoriais } \\
\text { muito poderosos } \\
(2006-)\end{array}$ & $\begin{array}{l}\text { Apenas relatores } \\
\text { setoriais cuidam } \\
\text { do orçamento }\end{array}$ \\
\hline
\end{tabular}

\section{1) Poder do Relator-Geral para emendar o orçamento}

Vimos, na primeira seção deste capítulo, como o poder do relator-geral para emendar o orçamento foi usado de modo diferente no período dominado pelos "anões do orçamento" (1988-1993) e no período em que a coalizão liderada pelo Executivo controlou o processo orçamentário (1994 - ). Cabe agora analisar quais idéias sobre esta prerrogativa institucional circularam nas duas critical junctures, como e por quem elas foram defendidas, e por que foram adotadas ou não.

Até a Resolução 2/1994, utilizada apenas para regulamentar a tramitação do orçamento para 1995, as emendas de relator-geral não eram de modo alguma limitadas. Para facilitar a vontade individual do legislador, por vezes corrupta, não havia nem mesmo a previsão de que essas emendas fossem publicadas para conhecimento dos outros parlamentares, assessores e demais interessados. A Resolução 2/1994 mostrou 
preocupação com esse ponto, ao exigir que "as emendas de Relator-Geral que venham a ser formuladas com vistas ao cumprimento de suas responsabilidades serão publicadas como parte do relatório, com indicação do proponente e dos respectivos fundamentos".

Ainda durante a critical juncture de 1994-1995, a assessoria técnica do Congresso Nacional sugeriu que o relator-geral se limitasse a "consolidar as propostas dos Relatores Setoriais, promover as correções que se fizerem necessárias e eventuais ajustes em cumprimento do disposto no parecer preliminar, vedada a apresentação de emendas que contenham matéria nova" (grifo meu).

Ambas as sugestões foram incorporadas na Resolução 2/1995, resultante do controle da coalizão sobre a critical juncture que terminou naquele ano ${ }^{152}$. Trata-se de um caso de "preferência deslocada", pois é um exemplo de parlamentares da coalizão defendendo menos prerrogativas para o relator-geral do processo orçamentário. $\mathrm{O}$ raciocínio que embasa isto é que, como a coalizão forma maioria, costuma indicar o relator-geral da comissão orçamentária. Quanto mais poderoso este relator-geral, mais poderosa será a coalizão. No entanto, o impacto do escândalo dos "anões do orçamento" é explícito neste ponto. Esse status quo foi mantido, em seus termos básicos, pela Resolução $1 / 2001^{153}$.

Em 2005, houve outro caso de "preferência deslocada" em relação ao poder de emendamento do relator-geral. Trata-se de uma idéia do parlamentar Sérgio Miranda (PC do B, coalizão) de que uma comissão avalie as emendas do relator-geral. Disse ele:” O poder de inserção do relator-geral tem de ser inibido. Emenda de relator-geral tem de ser avaliada por uma comissão, tem de haver parecer sobre as emendas. Nossas emendas passam por esse aval, por que não as de relator-geral?" (Comissão 2005, 20/4/2005, p. 50). No entanto, sua proposta não empolgou nem mesmo o entrepreneur de oposição que tanto influenciou aquela critical juncture: o deputado Ricardo Barros ${ }^{154}$ (PP).

A proposta de Barros expressava bem sua posição como parlamentar da oposição, pois impunha mais alguns limites ao poder de emendamento do relator-geral. (Como vimos na primeira seção deste capítulo, a emenda de relator-geral no período

\footnotetext{
${ }^{152}$ Conforme o segundo capítulo argumenta, a coalizão controlou a agenda da critical juncture terminada em 1995 pois o relator do Grupo de Trabalho formado para reescrever as regras orçamentárias pertencia à coalizão e não havia um entrepreneur da oposição para propor regras diferentes.

${ }^{153}$ Ver a tabela 1 do Anexo III para todas as propostas de escolha institucional que circularam sobre este ponto de 1988 a 2008.

${ }^{154}$ A influência de Ricardo Barros nesta critical juncture deve-se ao fato de ele haver relatado o Grupo de Trabalho criado em 2005 para pensar em novas regras orçamentárias e, também, à sua tenacidade em passar seu projeto de resolução resultante desta relatoria no plenário ao fim de 2006.
} 
após os "anões do orçamento" tornou-se um meio de a coalizão calibrar diversas demandas parlamentares.) Em seu projeto de resolução de 2005, Barros propôs: “Os relatores somente poderão apresentar emendas à programação da despesa com a finalidade de: I) corrigir erros e omissões de ordem técnica ou legal; II) recompor, total ou parcialmente, dotações canceladas, limitada a recomposição ao montante originalmente proposto no projeto; III) atender às especificações do parecer preliminar. É vedada a apresentação de emendas que tenham por objetivo a inclusão de subtítulos novos, bem como o acréscimo de valores a dotações constantes dos projetos". Com modificações mínimas, a Resolução 1/2006 manteve a proposta de Barros.

O resultado é a diminuição da autonomia do relator-geral para emendar o orçamento, mais até do que em 1995. Naturalmente, a correção de "erros e omissões de ordem técnica ou legal" pode abrir espaço para que o relator-geral aja informalmente de modo a aumentar seu poder de emendamento. A ver.

\section{2) Poder do Relator-Geral para estimar a Receita}

A prerrogativa de reestimar a receita que consta da proposta orçamentária enviada pelo Executivo é, como vimos na primeira seção deste capítulo, um poderoso instrumento a favor tanto de parlamentares corruptos quanto da coalizão. O uso da reestimativa de receita pelos "anões do orçamento" fez com que a CPI do Orçamento de 1993-1994 proposusse a descentralização completa deste mecanismo. "As receitas seriam avaliadas pela Comissão de Finanças e Tributação da Câmara dos Deputados e a Comissão de Assuntos Econômicos do Senado Federal", de acordo com o relatório da CPI, cabendo à comissão orçamentária decidir apenas as despesas a serem realizadas a partir da receita pré-fixada.

Esta idéia não prosperou. Membro do grupo de trabalho coordenado por José Fogaça em 1995 para reformular as resoluções que tratam do processo orçamentário, o deputado Paulo Bernardo propôs torna o relator-geral explicitamente responsável por estimar a receita. Trata-se de um caso de "preferência deslocada", pois, como parlamentar da oposição, Bernardo deveria querer que a receita fosse estimada de modo descentralizado. Sua idéia foi adotada na Resolução 2/1995. Além disso, vale lembrar que esta mesma resolução institucionalizou o mecanismo da "correção de erros e omissões" usado por parlamentares corruptos antes de 1993 para facilitar e legitimar a reestimativa de receitas. 
Há um esboço de descentralização deste ponto na Resolução 1/2001, que propõe a criação do Comitê de Avaliação da Receita Orçamentária, coordenado pelo relatorgeral. No entanto, trata-se de um comitê sem poderes reais, pois suas "conclusões e recomendações dos comitês estarão previamente disponíveis na comissão e subsidiarão os Relatores-Setoriais e o Relator-Geral, sendo parte integrante do relatório final”. O comitê não funcionou do modo esperado: "A resolução 1/2001 dividiu responsabilidades na análise das receitas orçamentárias ao criar o Comitê de Avaliação das Receitas, com relator independente. No entanto, tal avanço não impediu que nos anos seguintes, ao longo do período de elaboração orçamentária no Legislativo, reestimativas crescentes das receitas fossem sucedendo-se de acordo com as pressões pela aprovação de emendas e gastos adicionais. Continuaram a ocorrer reestimativas de última hora, que possibilitavam ao Relator-Geral atender também de última hora a demandas novas e antigas" (Vieira 2008, p. 33-34).

Em março de 2005, o então presidente da Comissão Mista de Orçamento, Paulo Bernardo (PT), enviou ofício ao presidente do Congresso Nacional com diversas sugestões para reformular o processo orçamentário. Três delas referiam-se à estimativa de receitas: i) adotar na LDO normas que visem a compatibilização das metodologias de previsão dos Poderes Executivo e Legislativo quanto a receitas e despesas obrigatórias de forma a afastar a subavaliação de despesas obrigatórias na proposta orçamentária, principal causa do contingenciamento; ii) restringir a possibilidade de se reestimar a receita a um único momento; iii) atribuir a uma relatoria específica a análise da receita. Curiosamente, trata-se de outro exemplo de "preferências deslocadas" de Bernardo, desta vez defendendo a descentralização da estimativa de receita apesar de pertencer à coalizão.

No mesmo mês, o entrepreneur Ricardo Barros (PP, oposição) apoiou, na comissão instituída para reformar o processo orçamentário, a criação do Relator da Receita e a fixação de 31/outubro como data-limite para reestimar a receita todo ano. Barros não economizou enquadramentos discursivos para tentar convencer os parlamentares de sua proposta. Primeiro utilizou o enquadramento referente à "barganha política" que causaria o aumento indevido da receita ${ }^{155}$; em seguida, apelou à suposta

155 “Temos que discutir a separação do relator da receita do relator da despesa, ou seja, adotar um relator de receita com prazo definido. Em 15/novembro, ou 30/outubro, a receita tem de estar aprovada e não se muda mais. Hoje os relatórios da receita e da despesa são os mesmos, e conforme a pressão sobre a despesa, encontra-se mais razões para justificar o aumento da receita. Com essa separação, teríamos mais 
“democratização" do processo que o Relator da Receita traria ${ }^{156}$ e, por fim, utilizou o enquadramento referente à "difusão", ao afirmar que estava sugerindo o Relator da Receita "por causa de uma discussão que existe sobre separação da receita e despesa em outros parlamentos" (Comissão 2005, 7/4/2005, p. 199).

Se o entrepreneur Ricardo Barros foi insistente ao propor a separação entre relatar a receita e a despesa, bem como fiel ao seu papel como membro da oposição, o mesmo não ocorreu com alguns parlamentares da coalizão e da oposição. "Preferências deslocadas" foram bastante comuns ${ }^{157}$. O deputado Iberê Ferreira (PTB, coalizão) afirmou, por exemplo que concorda inteiramente "com a indicação de dois relatores, o da receita e o da despesa. O relator chama cinco pessoas para conseguir aprovar a receita, visto que a pressão é enorme e só assim poderá fechar o orçamento. Um Relator de Receita vai nos dar condição para justificar a limitação do contingenciamento. $O$ próprio governo não pode reclamar desde que haja um relator específico da receita, que irá apresentar seu relatório antes da elaboração orçamentária" (Comissão 2005, 31/3/2005, p. 100). Ainda assim, parlamentares como Carlito Merss (PT) e Jorge Bittar (PT) foram extremamente veementes na oposição ao Relator da Receita. Daí o estranhamento ao ler, na justificativa do projeto de Ricardo Barros, que este trouxe “importantes avanços que obtiveram consenso, como o Relator da Receita"

Quanto a parlamentares da oposição, dois foram contra o Relator da Receita indicado pela oposição, incorrendo em "preferências deslocadas". Para Fernando Coruja (PPS, oposição), “a indicação de um Relator da Receita pelo líder da minoria é complicada. Estamos tratando de uma questão de elaboração do orçamento, que é fundamentalmente de governo. Embora tenhamos participação ampla, temos que tomar cuidado para não criar um conflito. Imaginem se o líder da minoria acha que a receita é

segurança. Além disso, o relator da despesa terá de trabalhar com aquele limite aprovado anteriormente, isto é, no início de seu trabalho na comissão.” (Comissão 2005, 31/3/2005, p. 96)

156 “O relator da despesa é indicado pelo maior partido ou pelo acordo com o governo. O relator da receita é indicado pela minoria. A minoria autoriza e o governo gasta. Estou propondo uma democratização do trabalho legislativo" (Comissão 2005, 5/4/2005, p. 142). Outro exemplo foi sua afirmação de que propõe o Relator da Receita "com o objetivo de que aquele que reestimar a receita não seja o mesmo que vai aplicar a receita reestimada. Com isso, esperamos ter mais isenção na reestimativa da receita. Pois o relatório da receita será aprovado antes do parecer preliminar, sendo que o seu resultado final fará parte, portanto, do parecer preliminar, não podendo mais ser alterada a receita até o final da tramitacao do orçamento. Não teremos mais aquela reincidência da alocação de novos recursos durante a tramitação, o que prejudica especialmente aqueles relatores setoriais que não participaram da discussão acerca da disposição desses novos recursos" (Comissão 2005, 20/4/2005, p. 31-32).

${ }^{157}$ Ver a lista completa no anexo III a este capítulo, que contém todos os enquadramentos discursivos utilizados por parlamentares em relação às escolhas sobre a Comissão Mista de Orçamento.

${ }^{158}$ Barros (2007, p. 40) escreveu também que "os deputados Jorge Bittar e Carlito Merss entenderam e apoiaram a criação do Relator da Receita”, afirmação que a leitura das atas da Comissão de 2005 não autoriza. 
tanto e o da maioria acha que é outro tanto, vai-se criar um conflito, independentemente de quem esteja no governo" (Comissão 2005, 5/4/2005, p. 143-144). Esta posição prosperou contra a vontade de Ricardo Barros. Resignado, afirmou que o "Relator da Receita será também da maioria, mas da Casa, indicado pelo presidente" (Comissão 2005, 24/5/2005, p. 249).

A CPI das Ambulâncias, cujo relatório foi publicado em agosto de 2006, calouse sobre a criação do Relator da Receita, limitando-se a sugerir que fosse estabelecido em Lei Complementar ou na Lei de Diretrizes Orçamentárias "normas de compatibilização das metodologias de previsão de receitas e despesas obrigatórias pelo Executivo e Legislativo de modo a afastar a subavaliação de despesas obrigatórias e a reestimativa de receita, causas importantes do contingenciamento".

Por fim, a Resolução 1/2006 estabeleceu que o Relator da Receita não poderá pertencer à mesma Casa, partido ou bloco parlamentar do Relator-Geral, o que não impede que a coalizão controle esses dois cargos. (Afinal, o Relator-Geral pode ser um senador do PT e o Relator da Receita um deputado do PMDB). A resolução manteve o Comitê de Avaliação da Receita. Em linha com a recomendação da CPI das Ambulâncias, determinou que "a metodologia a ser utilizada na análise da estimativa da Receita deverá ser a estabelecida na lei de diretrizes orçamentárias” (art. 33). Estabeleceu também o conteúdo do Relatório da Receita, que deverá conter “i) exame da conjuntura macroeconômica e do endividamento e seu impacto sobre as finanças públicas; ii) análise da evolução da arrecadação das receitas e da sua estimativa no projeto, com ênfase na metodologia e nos parâmetros utilizados; iii) avaliação, em separado, das receitas próprias das entidades da administração indireta, em especial as pertencentes às agências reguladoras; iv) demonstrativo das receitas reestimadas, comparando-as com as do projeto, classificadas por natureza e fonte; v) demonstrativo das propostas de pareceres às emendas à receita e de renúncia de receitas; vi) o montante de eventuais recursos adicionais decorrentes da reestimativa das receitas, discriminando as variações positivas e negativas por natureza e fonte de recursos; vii) indicação dos montantes de despesa a serem reduzidos no Parecer Preliminar, quando necessário; viii) a verificação do atendimento às normas constitucionais e legais pertinentes à Receita, especialmente quanto à compatibilidade do projeto com a lei do plano plurianual, a lei de diretrizes orçamentárias e a Lei Complementar $n^{\circ} 101$, de 2000”. 
Nota-se que o relator-geral se vê obrigado a partilhar poder com o Relator da Receita, tendo que incluí-lo em suas deliberações para escrever o parecer preliminar. Recentemente, o projeto de resolução 4/2008 afirma que "a criação da relatoria da receita mostrou-se adequada, permitindo a discussão antecipada e autônoma da receita. Como aperfeiçoamento, propõe-se a inserção de dispositivo prevendo que os ajustes, na hipótese de reestimativa negativa da receita, situação que ocorreu nos últimos dois anos, incidam em todo o projeto de lei e suas alterações". O autor do projeto, Delcídio Amaral (PT), refere-se sobretudo à extinção da Contribuição Provisória sobre Movimentação Financeira no fim de 2007, o que forçou a coalizão a cortar $\mathrm{R} \$ 24,7$ bilhões do orçamento para 2008.

\section{3)Existência da Comissão Orçamentária e institucionalização de subcomissões}

Antes da CPI de 1993-1994, a comissão orçamentária tinha a prerrogativa de criar subcomissões temáticas permanentes de modo a realizar seus trabalhos de modo descentralizado, segundo a Resolução 1/1991, se os parlamentares assim desejassem. Não há notícia de que os "anões do orçamento" tenham adotado esse desenho institucional: afinal, a centralização dos poderes da CMO servia bem seus interesses.

A comissão que os investigou fez cinco sugestões radicais: i) extinção da Comissão Mista de Orçamento; ii) a LDO seria discutida em todas as comissões técnicas permanentes da Câmara dos Deputados e Senado Federal; iii) as propostas orçamentárias setoriais seriam discutidas e elaboradas nas comissões técnicas da Câmara dos Deputados e Senado Federal, com participação de representantes do Executivo; iv) as comissões técnicas permanentes da Câmara e Senado fiscalizariam a execução orçamentária; v) seria criada a Comissão Parlamentar Mista de Sistematização Orçamentária (com disciplina definida pelo Regimento Interno, não pela Constituição), que zelaria pelo cumprimento dos prazos de tramitação dos projetos e supriria deficiências das comissões técnicas, além de consolidar as propostas setoriais.

Nem a assessoria técnica teve idéias tão drásticas. Os assessores sugeriram dois pontos. O primeiro seria dividir a comissão em oito subcomissões temáticas permanentes, que seriam responsáveis pela discussão e votação das propostas de lei orçamentária e seus créditos adicionais. O segundo seria escolher os relatores setoriais de modo que fossem representantes das comissões técnicas permanentes do Senado Federal e da Câmara dos Deputados. 
As sugestões da CPI e da assessoria técnica não foram adotadas. A única modificação se deu em relação à obrigatoriedade das subcomissões temáticas permanentes. Se na Resolução 1/1991 as subcomissões eram opcionais, na Resolução 2/1995 elas se tornaram obrigatórias - mas, ainda assim, tiveram existência bastante irregular de 1995 a $2006^{159}$.

Novo passo para a descentralização se deu em 2001, quando a Resolução 1/2001 decidiu pela criação de até cinco comitês coordenados pelo Relator-Geral, sendo três obrigatórios: i) Comitê de Avaliação da Receita Orçamentária; ii) Comitê de Avaliação das Emendas e iii) Comitê de Avaliação das Informações enviadas pelo Tribunal de Contas da União. Teriam a função de informar os relatores setoriais e o relator-geral.

Em março de 2005, o presidente da Comissão Mista de Orçamento, Paulo Bernardo (PT), enviou ofício ao presidente do Congresso Nacional sugerindo modificações no processo orçamentário. Duas delas diziam respeito à descentralização da comissao: i) criação do Comitê de Acompanhamento e Fiscalização da Execução Orçamentária com a designação dos integrantes do comitê de acordo com as relatorias setoriais do ano anterior e ii) realização de audiência públicas obrigatórias com os relatores setoriais nas comissões permanentes correspondentes. São duas propostas bastante brandas, até condizentes com a posição de Bernardo como membro da coalizão. Três parlamentares da coalizão foram contra essas propostas durante as discussões da comissão formada para discutir a reforma orçamentária.

Um único parlamentar da coalizão, Sérgio Miranda (PC do B, coalizão), manifestou uma "preferência deslocada" em relação à descentralização, apoiando a continuidade do Comitê de Admissibilidade de Emendas criado em 2001. Utilizou o enquadramento discursivo "corrupção": "Quando se fez a CPI do Orçamento, a questão que resultou em cassação de mandatos foi a das emendas para as subvenções sociais. Então o Comitê de Admissibilidade de Emendas se justifica para cuidar desse aspecto" (Comissão 2005, 7/4/2005, p. 188-189).

Como poder-se-ia esperar, o entrepreneur da oposição à época, Ricardo Barros (PP, oposição) defendeu diversas idéias favoráveis à descentralização da Comissão Mista de Orçamento. Além de concordar com a continuidade dos comitês já existentes, Barros propôs que as comissões temáticas da Câmara dos Deputados e Senado Federal cuidassem do processo de emendamento orçamentário, funcionando como relatoriais

\footnotetext{
${ }^{159}$ Ver breve discussão na primeira seção deste capítulo.
} 
setoriais. Isso interessa à oposição pois é praticamente impossível a coalizão controlar todas as comissões temáticas - assim, os oposicionistas teriam diversos lugares para fazer avançar suas preferências orçamentárias.

Barros utilizou dois enquadramentos discursivos para defender essa idéia. O primeiro foi o referente à "difusão", ao dizer que "há a possibilidade de a comissão orçamentária, a exemplo do sistema americano, fazer apenas a macrodistribuicao de verbas - quanto é para a Educação, por exemplo -, realizando receitas e alocação de despesas por área. Cada comissão temática, em conjunto com a subcomissão do Senado, faria a destinação específica daquela verba. As relatorias setoriais passariam a ser as comissões temáticas instaladas na Câmara e Senado" (Comissão 2005, 30/3/2005, p. 24). O segundo foi o enquadramento referente aos ganhos com a especialização parlamentar, afirmando que "o debate do relatório setorial seria realizado por especialistas, que são os parlamentares que se dedicam o ano inteiro àquela área e atualmente, na hora de discutir o orçamento, ficam de fora" (Comissão 2005, 5/4/2005, p. 138-139).

Seus colegas da oposição em 2005 foram unânimes no apoio às propostas de descentralizar o processo orçamentário ${ }^{160}$. No entanto, ao fazer seu projeto de resolução, Barros optou por amenizar o poder das comissões temáticas, propondo que "as comissões permanentes do SF e da CD cujas competências materiais sejam correlatas poderão, em conjunto, sugerir ao RG a inclusão, no relatório preliminar, de até três programas ou ações, por área ou subárea temática, para integrar a programação prioritária passível de emendas (...)”. Além disso, seriam constituídos quatro comitês: i) Comitê de Avaliação, Fiscalizacao e Controle da Execucao Orçamentária; ii) Comitê de Avaliação da Receita; iii) Comitê de Avaliação das Informacoes sobre Obras e Serviços com Indícios de Irregularidades Graves e iv) Comitê de Exame de Admissibilidade das Emendas ${ }^{161}$.

\footnotetext{
${ }^{160}$ Ver a terceira tabela do Anexo III para uma lista completa de quem defendeu cada proposta.

${ }^{161}$ Barros (2007, p. 33) explica os objetivos de cada um deles: "São quatro os comitês permanente que terão entre 5 e 10 membros. O comitê de avaliação da receita é destinado a acompanhar a evolução da Receita e auxiliar o relator da Receita. O comitê de avaliação das informações sobre obras e serviços com indícios de irregularidades graves, que atualizará as informações, proporá o aperfeiçoamento nos procedimentos e sistemáticas relacionadas com o controle externo de obras e serviços que recebem recursos federais. O comitê de admissibilidade de emendas avaliará as emendas ao projeto de lei orçamentária, Plano Plurianual, Lei de Diretrizes Orçamentárias, créditos e emendas de relator, sem cujo parecer elas não poderão ser votadas pela CMO. Foi criado um novo comitê permanente: o de avaliação, fiscalização e controle da execução orçamentária, visando dar à CMO uma visão mais clara da real situação orçamentária, permitindo a avaliação da política de execução do orçamento praticada pelo Executivo".
} 
Ao contário do caso dos "anões do orçamento", o escândalo dos "sanguessugas" não teve impacto nas idéias sobre descentralização do processo orçamentário. No relatório, afirmou-se ser "equivocada a correlação entre a existência da CMO e seu processo decisório concentrado com o escândalo da Operação Sanguessuga, já que as denúncias de superfaturamento na venda de ambulâncias e ônibus escolares a prefeituras envolvem a execução orçamentária e não a apreciação da proposta orçamentário" (Relatório da CPI das Ambulâncias, 2006, p. 96).

Assim, a Resolução 1/2006 adotou as propostas diluídas de Ricardo Barros. A participação das comissões temáticas no processo orçamentário continua incipiente. De acordo com Vieira (2008, p. 32-33) apesar de esta resolução prever "a realização de debates em audiência pública conjunta entre as comissões temáticas e a CMO com a finalidade de subsidiar os relatórios setoriais do orçamento, podendo ser convidados para participar membros da sociedade civil. Observa-se nas pautas de convocação para reuniões ordinárias ou extraordinárias da Comissão Mista de Orçamento, entretanto, que essas reuniões conjuntas não ocorreram, basicamente por falta de entendimento político".

O mais recente projeto de resolução congressual sobre o processo orçamentário trata apenas da questão da admissibilidade das emendas, elogiando o "papel saneador das emendas, especialmente das coletivas, desempenhado pelo Comitê de Admissibilidade das Emendas. A atuação deste comitê demonstrou a conveniência de instancia autônoma coletiva com perfil técnico-jurídico na admissibilidade. Também mostrou a necessidade de prever sua atuação conjunta com as relatorias setoriais, especialmente no exame da admissibilidade das emendas individuais, o que contribui para a celeridade do processo" (Projeto de Resolução 4/2008-CN, 18/12/2008). O que Delcídio Amaral, proponente do projeto, deixa de relatar é a briga entre alguns relatores setoriais e o comitê, pois o comitê tem evitado barrar diversas emendas coletivas que ferem certas regras. Trata-se de uma informalidade do processo orçamentário brasileiro, que deve ser analisada futuramente.

Podemos apreender que no caso da existência da Comissão Mista de Orçamento e sua divisão em subcomissões, os escândalos de corrupção tiveram pouquíssimo impacto. A CPI dos "anões do orçamento" até sugeriu o fim da CMO, mas esta idéia não foi levada adiante pela coalizão que controlou a critical juncture de 1994-1995. Além disso, praticamente não houve "preferências deslocadas" dos atores. Afinal, já 
analisei casos em que a associação de certa instituição à corrupção pode ter ajudado a provocar o deslocamento de preferência dos atores.

\section{4) Relação do Relator-Geral com Relatores Setoriais}

Por fim, analisarei um ponto referente à relação do relator-geral com os relatores setoriais da Comissão Mista de Orçamento. Trata-se da liberdade dos relatores setoriais para manejar recursos vis-à-vis o relator-geral. As primeiras resoluções congressuais que trataram do processo orçamentário no periodo democratico - 1/1991, 1/1993 e 2/1995 - desenharam essa relação de modo a dar enormes prerrogativas ao relator-geral e pouquíssima relevância aos relatores setoriais.

De acordo com a a Resolução 1/1991, cabe ao relator-geral "adequar os pareceres setoriais aprovados, vedada qualquer modificação de parecer setorial, ressalvadas as alterações por ele propostas e aprovadas pelo Plenário da Comissão, bem como as decorrentes de destaques aprovados pela Comissão". A Resolução 2/1995 manteve este desenho básico, com modificações mínimas. Na prática, isso dava ao relator-geral o poder para mudar os relatórios setoriais à vontade. Segundo assesssores técnicos do processo orçamentário no Senado Federal, “depois da Resolução de 1995, se o relator-geral quisesse pegar os relatórios setoriais, jogar no lixo e fazer tudo de novo, ele podia. Simplesmente pegaria tudo que o relator setorial aprovou e mudaria a alocação dos recursos. Esse foi o motivo pelo qual a Resolução de 2006 tentou ao máximo apertar o parafuso do relator-geral com relação a varios pontos: o percentual de recursos que ele tem para usar, a distribuição de recursos entre os relatores setoriais etc. Tudo isso para não deixar o Relator-Geral simplesmente destruir o relatório setorial. O Relator-Geral deveria pegar os relatórios setoriais e ajustá-los, decidindo apenas as grandes questões como o salário-mínimo (que impacta a previdência) e parâmetros macroeconômico que perpassam os relatórios setoriais. Mas a maior parte do relatório setorial deveria ser preservada e isso não estava nas resoluções antes de 2006. A resolução de 2006 serviu bem para definir percentualmente os valores para que o Relator-Geral não pudesse definir sozinho a distribuição de recursos para cada relator setorial" $" 162$.

\footnotetext{
162 Entrevista com os consultores de Orçamento Carlos Marshall e Fernando Ramalho Bittencourt, Senado Federal, Maio/2008.
} 
Nao é de espantar, então, que o deputado Paulo Bernardo e o entrepreneur Ricardo Barros tenham sugerido o fortalecimento das relatorias setoriais em relação ao Relator-Geral. Em março de 2005, Bernardo (PT, coalizão) sugeriu, incorrendo em "preferências deslocadas", ou dar exclusividade ao acolhimento das despesas discricionárias pelas relatorias setoriais ou estabelecer limites e critérios à relatoria geral, no parecer preliminar, para remanejamento e cancelamentos na programação constantes dos relatórios setoriais. Trata-se de "preferências deslocadas" porque, como membro da coalizão, Bernardo deveria defender mais poderes para o Relator-Geral.

O entrepreneur Ricardo Barros foi um passo além. Sugeriu, também em março de 2005, na comissão criada para estudar reformas no processo orçamentário, dois pontos: i) vedação da possibilidade de o relator-geral alterar as dotações aprovadas nos relatórios setoriais, exceto para aumentar os seus valores e ii) definição, na resolução, dos percentuais da reestimativa de receita à disposição dos relatores setoriais e do relator-geral. Esse era o comportamento a esperar de Barros como membro da oposição. Não há "preferências deslocadas".

Barros defendeu esses pontos para "terminar com o papel secundário das relatorias setoriais e a possibilidade de revisão, pela relatoria geral, sem critérios definidos, dos relatórios setoriais já aprovados" (Comissão 2005, 31/3/2005, p. 110111). Afirmou, ainda, que "não podemos continuar repetindo o modelo atual, em que o relator setorial tem muito pouca importância no resultado final do que foi alocado, porque os valores que acabam ficando para o relator setorial são muito pequenos perto do conjunto das reestimativas feitas posteriormente à sua participação" (Comissão 2005, 24/5/2005, p. 252). Em seu projeto de resolução, Barros propôs, entre diversos outros pontos, que: i) Os relatores setoriais utilizarão como fontes de recursos para atendimento de emendas coletivas de apropriação aquelas definidas no parecer preliminar; ii) o Relator-Geral poderá propor em seu relatório acréscimos e cancelamentos nos valores das emendas coletivas de apropriação aprovadas nos pareceres setoriais, utilizando como fontes de recursos aquelas definidas no parecer preliminar e iii) é vedado ao Relator-Geral propor a aprovação de emendas com parecer setorial pela rejeição.

Curiosamente, dois parlamentares tiveram "preferências deslocadas" em relação às propostas de Barros. Laura Carneiro (PFL, oposição) sugeriu não definir o critério de distribuição dos recursos disponíveis para os relatores setoriais na resolução congressual, pois seria um "engessamento" do trabalho do Relator-Geral (Emenda ao 
Projeto Ricardo Barros, 13/9/2005). Por sua vez, Gilmar Machado (PT, coalizão) apoiou as idéias de Barros, dizendo que "dividir o poder do Relator-Geral é dar mais transparência e fazer com que o Relator-Geral tenha de realizar debates mais abertos, possibilitando que os relatores setoriais tenham mais força e, ao mesmo tempo, debatam os projetos e os programas nas comissões temáticas" (Comissão 2005, 7/4/2005, p. 194). Estas preferências são deslocadas porque Carneiro, da oposição, deveria defender menos poderes para o Relator-Geral (cargo que, afinal, a oposição não controla), enquanto Machado, da coalizão, deveria defender o inverso.

A decisão final da Resolução 1/2006 resultou em vitória complete para Barros neste quesito. Suas três propostas foram aprovadas. Decidiu-se que "os recursos líquidos destinados ao atendimento de emendas coletivas de apropriação terão o seguinte destino, observada a vinculação de fontes: i) 25\% para as emendas de Bancada Estadual...; ii) 55\% aos Relatores Setoriais, para as emendas de Bancada Estadual e as de Comissão; iii) 20\% ao Relator-Geral, para alocação, entre as emendas de Bancada Estadual e de Comissão, sendo que o Relator-Geral assegurará que o montante de recursos destinado ao atendimento de emendas de Comissão não seja inferior a $15 \%$ do total dos recursos líquidos”. Em outras palavras, a resolução assegura que uma parcela dos recursos será decidida de modo autônomo pelos relatores setoriais.

Barros comemorou, mais tarde, afirmando que "esta decisão eliminará a distorção repetida em muitos relatórios, em que o Relator-Geral aplicava em média 74\% dos recursos decorrentes de sucessivas reavaliações de receita. De 2002 a 2007, a maior participação do Relator-Geral foi de 80,68\% em 2003 e a menor foi em 2007, com $62,37 \%$. A partir desta nova resolução, caberá ao Relator-Geral 20\% dos recursos" (Barros 2007, p. 27). O raciocínio é complementado por Vieira (2008, p. 35), para quem “as modificações concretizadas na resolução 1/2006, ao tornar, mais transparente a avaliação da receita, tem também o potencial de tornar menos forte a figura do RG em face aos relatores setoriais. O papel dos relatores setoriais se eleva na medida em que o conhecimento antecipado dos recursos oriundos da reestimativa da receita permite que o atendimento por eles definido, relativo às emendas coletivas, seja efetivo. Não há, em tese, o risco de que o RG, promovendo nova rodada de distribuição de dotações, acabe por distorcer completamente as decisões tomadas no âmbito das relatorias setoriais".

Cabe, agora, analisar brevemente uma decisão institucional tomada a partir do interesses em postos de poder institucional, um dos destacados por Schickler (2001). Trata-se da decisão da Resolução 1/2006 de definir que "o critério de rodízio será 
adotado na designação dos Relatores Setoriais do projeto de lei orçamentária anual, de forma que não seja designado, no ano subseqüente, membro de mesmo partido para relator da mesma área temática". De acordo com o entrepreneur Ricardo Barros, "isso é para acabar com aqueles feudos, porque o partido tal todo ano quer infra-estrutura , o outro partido todo ano quer educação... Então queremos alternar”. (Comissão 2005, 5/4/2005, p. 144). Foi uma medida também defendida no Relatório da CPI das Ambulâncias, em agosto de 2006.

Três parlamentares do PMDB propuseram emendas ao projeto de resolução de Barros com o intuito de derrubar a medida, mobilizando enquadramentos discursivos referentes à "proporcionalidade partidária". Para ficar em um exemplo, vale citar a emenda de Alberico Filho, para quem a resolução deveria manter o respeito ao princípio da proporcionalidade, permitindo aos partidos a livre escolha das áreas temáticas, restringindo apenas a repetição do relator, o que preserva o objetivo da alternância" (Emenda ao Projeto Ricardo Barros, 30/5/2006). O PMDB notoriamente indica o relator setorial da área de Transportes na Comissão Mista de Orçamento. Há, portanto, um forte interesse na manutenção de postos de poder institucional desse tipo por trás da ação do PMDB. Mas o partido não obteve sucesso.

\section{(3) Conclusões}

Para concluir, vale salientar três pontos. O primeiro é que o entrepreneur Ricardo Barros não teve "preferências deslocadas" sobre nenhum dos aspectos analisados. Isto demonstra que a descentralização da Comissão Mistade Orçamento era algo importante para ele. Barros obteve sucesso em praticamente todos os pontos em 2006, bem como a coalizão teve sucesso, em 1995, em manter o desenho orçamentário centralizado que lhe interessava, como mostra a tabela 5.4. 
Tabela 5.4: Corrupção, entrepreneurs e escolhas sobre a organização da CMO, 1988-2008

\begin{tabular}{|l|l|l|l|l|}
\hline & $\begin{array}{l}\text { Caso pode ser } \\
\text { associado à } \\
\text { corrupção? }\end{array}$ & $\begin{array}{l}\text { Atores tinham } \\
\text { preferências } \\
\text { deslocadas? }\end{array}$ & $\begin{array}{l}\text { Entrepreneur } \\
\text { em 2006 tinha } \\
\text { preferências } \\
\text { deslocadas? }\end{array}$ & $\begin{array}{l}\text { Resultado final é } \\
\text { paradoxal ou } \\
\text { não? }\end{array}$ \\
\hline $\begin{array}{l}\text { Poder de Relator- } \\
\text { Geral emendar } \\
\text { orçamento }\end{array}$ & $\begin{array}{l}\text { Sim, sobretudo em } \\
1995\end{array}$ & $\begin{array}{l}\text { Sim, em 1995; um } \\
\text { pouco em 2005 }\end{array}$ & Não & $\begin{array}{l}\text { Sim (1995) } \\
\text { Não (2006) }\end{array}$ \\
\hline $\begin{array}{l}\text { Poder de Relator- } \\
\text { Geral estimar } \\
\text { receita }\end{array}$ & $\begin{array}{l}\text { Sim, sobretudo em } \\
1995\end{array}$ & Sim, diversos & Não & $\begin{array}{l}\text { Não (1995) } \\
\text { Não (2006) }\end{array}$ \\
\hline $\begin{array}{l}\text { CMO como } \\
\text { responsável pelo } \\
\text { orçamento }\end{array}$ & $\begin{array}{l}\text { Sim, muito, mas } \\
\text { apenas em 1995 }\end{array}$ & $\begin{array}{l}\text { Não, com uma } \\
\text { pequena exceção }\end{array}$ & Não & $\begin{array}{l}\text { Não (1995) } \\
\text { Sim (2006) }\end{array}$ \\
\hline $\begin{array}{l}\text { CMO com } \\
\text { relatores setoriais } \\
\text { poderosos }\end{array}$ & Não & Sim, diversos & Não & $\begin{array}{l}\text { Não (1995) } \\
\text { Não (2006) }\end{array}$ \\
\hline
\end{tabular}

O segundo ponto é que é fundamental avaliar também como as regras são seguidas na prática. O enorme sucesso do entrepreneur pode não ser sinal de força política dele; pode se tratar de indiferença de diversos atores ao processo de tramitação da resolução congressual. Esta indiferença se transforma, quando as regras são implementadas de fato, em falta de “compliance". Há, por exemplo, diversas interpretações dos relatores setoriais sobre o valor que eles podem efetivamente realocar/decidir sobre. Sobre este ponto, afirmou-me uma consultora do processo orçamentário federal brasileiro: "No ano passado, cada relator setorial deu uma interpretação diferente para um mesmo dispositivo da Resolução 1/2006. Os dispositivos de 44 a 47 da resolução regulamentam quanto dinheiro eles teriam para alocar. São regras sobre de onde viriam os recursos para os relatores setoriais apontarem. Um teve uma interpretação liberal e conseguiu mais recursos, outro deu uma interpretação mais conservadora e conseguiu menos"163. Portanto, a aprovação de regras institucionais é apenas uma das etapas que deve ser considerada na análise de desenvolvimento institucional.

Finalmente, é interessante destacar como processos de mudança institucional gradual, como a conversão institucional (Mahoney e Thelen 2009) analisada na primeira parte do capítulo, são afetadas entrepreneurs e critical junctures. Como membro da oposição, Ricardo Barros estava claramente insatisfeito com o modo como a Comissão Mista de Orçamento foi convertida, após 1994, em uma instituição prócoalizão. Aproveitou-se, o máximo que pôde, da critical juncture de 2005-2006 para

\footnotetext{
${ }^{163}$ Entrevista com a consultora de orçamento Rita de Cássia Leal Fonseca dos Santos, Senado Federal, Maio de 2008.
} 
mudar este uso da comissão ao menos parcialmente, limitando alguns poderes do Relator-Geral e dando outros para os relatores setoriais. É um exemplo concreto de como a agency de um ator politico é limitada pelas estruturas institucionais. O próximo capítulo traz o caso de um entrepreneur que teve menos sucesso do que Barros: o senador Antônio Carlos Magalhães e sua proposta para tornar o Orçamento Impositivo. 


\section{Capítulo 6}

\section{A dinâmica da inércia: a estabilidade do Orçamento Autorizativo no Brasil}

"Einstein believed that inertia would not exist for something spinning in a completely empty universe. Instead, inertia was caused only by rotation relative to all the other objects in the universe" (Isaacson 2007, p. 251, ênfase do autor)

“...inaction results from the operations of political influence and political institutions..." (Crenson 1971, p. 27)

Nos últimos anos, cientistas políticos de diversas escolas analíticas, sobretudo os ligados ao institucionalismo histórico, têm procurado explicar processos de gênese e mudança de instituições políticas ${ }^{164}$. Algo que era tradicionalmente um ponto analítico obscuro em processos políticos tornou-se o foco principal de análise de diversos estudiosos desta corrente analítica, mas também de parte dos analistas filiados à linha da escolha racional ${ }^{165}$. Ainda que esta literatura tenha avançado enormemente em relação às causas e processos de mudança institucional ${ }^{166}$, a dinâmica que resulta na estabilidade de instituições fora de processos path dependent (Pierson 2000; Bennett e Elman 2006) tem merecido menos atenção.

O principal objetivo do capítulo é contribuir para esta literatura sobre dinâmicas institucionais ao explorar os mecanismos de controle da agenda que sustentam instituições orçamentárias no Brasil apesar de fortes incentivos para que houvesse mudança institucional $^{167}$. A ausência de Orçamento Impositivo de 1988 a 2008 incorrendo, assim, na estabilidade do Orçamento Autorizativo - é o paradoxo empírico analisado. A falta de path dependence no caso aqui analisado se deve ao fato de que a prerrogativa de o Executivo controlar a execução orçamentária no Brasil - ou seja, o Orçamento Autorizativo - não foi contingente, mas sim uma escolha institucional bastante ligada aos interesses do Executivo em diversos momentos da história política do país. Adoto aqui a exigência de Mahoney (2000) de que processos de estabilidade

\footnotetext{
${ }^{164}$ Parte do título deste capítulo é emprestado do texto de Genschel (1997) sobre mudanças institucionais nas áreas de telecomunicações e saúde na Alemanha, embora seu argumento seja mais relevante para pensar processos de mudança institucional como os tratados por Mahoney e Thelen (2009) do que o controle da agenda legislativa pelo Executivo como mecanismo de estabilidade institucional.

${ }^{165}$ Knight (1992), Knight e Sened (1995), Shepsle (2001).

${ }^{166}$ Krasner (1984), Schickler (2001), Thelen (1999, 2003, 2006), Hacker (2004), Streeck e Thelen (2005), Tsai (2006), Weyland (2008), Taylor (2009), Mahoney e Thelen (2009).

${ }^{167}$ Exemplos de análises de mudanças em instituições orçamentárias são Lindner (2003) e Stewart (1989).
} 
institucional só se caracterizam como path dependent caso o momento de gênese da instituição tenha sido contingente, ou seja, inexplicável teoricamente ${ }^{168}$.

A estabilidade do Orçamento Autorizativo ao longo de vinte anos da democracia brasileira pós-Constituição é paradoxal se considerarmos que a barganha política possibilitada pelo Orçamento Autorizativo em torno de emendas orçamentárias encontra fortes críticos acadêmicos (Pereira e Mueller 2004) e na burocracia (Pontes Lima 2003) e que a idéia de implementar o Orçamento Impositivo é recorrente na pauta de reformas orçamentárias no país. .

O que explica essa estabilidade institucional é a maneira como o Executivo brasileiro controla a agenda legislativa do país. Avaliar o controle da agenda política, conforme Moe (2005) sugere, pode ser um bom método para analisar qual é a extensão dos poderes de cada ator ou grupo político para manter ou alterar arranjos institucionais vigentes. $\mathrm{O}$ estudo de não-decisões é, além de fundamental para entender dinâmicas institucionais, bastante negligenciado pela literatura sobre instituições políticas brasileiras ${ }^{169}$. Quando ignoradas pelos analistas, essas não-decisões mascaram como inercial um processo que é dinâmico e conflituoso.

O capítulo está dividido em quatro seções. A primeira trata da relação teórica entre poder, mecanismos e controle da agenda. A segunda explica como parlamentares têm uma relação de apoio contingente com a instituição do Orçamento Autorizativo. Para finalizar, a terceira e a quarta seção tratam como, na prática, o entrepreneur Antônio Carlos Magalhães quase conseguiu efetuar a mudança institucional que desejava.

\section{1) Estabilidade institucional: poder, mecanismos e controle da agenda}

A perspectiva institucionalista histórica sobre dinâmicas institucionais tem fortes raízes em estudos sobre path dependence que "tradicionalmente frisam continuidade institucional em detrimento de mudanças" (Mahoney e Thelen 2009, p. 8). A estabilidade aqui é tratada como o resultado contingente de um processo dinâmico endógeno às instituições, no qual mecanismos de controle da agenda legislativa operam de modo a manter os desenhos institucionais vigentes apesar de forte pressão externa. Nesse sentido, as “instituições alocam recursos de modo desproporcional aos atores que

\footnotetext{
${ }^{168}$ O historiador John Lewis Gaddis (2002, p. 64) afirma que eventos contingentes são $a$ causa de gênese e mudança institucional.

${ }^{169}$ Exceções são Diniz (2005) e Mancuso (2007). Para um argumento semelhante em relação a políticas públicas nos Estados Unidos, ver Maltzman e Shipan (2008).
} 
já são poderosos, justamente porque estes são os que desenham as instituições. Atores políticos poderosos vêem seu poder aumentar à medida que o tempo passa, tendo assim mais capacidade para manter o desenho institucional com o qual se beneficiam" (Mahoney e Thelen 2009, p. 8-9). É preciso também identificar o funcionamento dos mecanismos que permitem aos atores fortes desenhar as instituições de modo que os satisfaça. Neste capítulo, o controle das organizações legislativas pela maioria congressual liderada pelo Executivo brasileiro é o mecanismo utilizado para alocar recursos a atores poderosos.

Como já mencionei, os processos de estabilidade e mudança institucional dependem de relações de poder entre atores políticos. Uma definição abrangente de poder aborda a capacidade de um ator ou grupo político assegurar seu resultado predileto com o luxo de poder ignorar ao menos parte das escolhas e ações dos oponentes (Goodin 1996, p. 1516). Neste processo, o controle da agenda é fundamental, pois "a definição de alternativas é o instrumento supremo de poder. Inimigos políticos raramente concordam em relação aos temas sobre os quais serão defendidas alternativas pró e contra, pois o poder é parte inerente a esta definição da agenda" (Schattschneider 1960, p. 68, citado por Walker 1977). Se a estabilidade de certa instituição é explicada pelo fato de esta fornecer vantagem distributiva (ou seja, relativa a poder) para quem tem autoridade e poder suficiente para mudá-la (Knight 1992), é evidente que assegurar tal estabilidade requer a mobilização contínua de apoio político.

Antes de considerar o controle da agenda legislativa pelo Executivo como a operacionalização empírica do conceito de poder, apresento os pontos básicos do argumento de Mahoney (2000) sobre estabilidade institucional e o modo como esta perspectiva, quando posta ao lado da proposta de Moe (2005), pertencente a linha analítica diversa, torna-se relevante para pensar a manutenção de instituições mesmo em processos que não são path dependent, como no caso aqui analisado.

Mahoney (2000) parte de Collins (1994) para analisar quatro perspectivas analíticas da sociologia que podem explicar a reprodução institucional em processos path dependent. São elas: perspectiva utilitarista, perspectiva funcionalista, perspectiva relativa a poder e perspectiva relativa a legitimação. A intenção do autor foi fornecer conteúdo empírico a essas quatro tradições teóricas, associando proposições empíricas específicas às quatro perspectivas.

Segundo a perspectiva utilitarista, certa instituição é reproduzida porque benefícios potenciais de mudança são vistos como menores do que custos de mudança. A 
perspectiva funcionalista, por sua vez, estabelece, de modo bastante parecido ao que Pierson (2004) chama de feedback positivo, que as instituições são reproduzidas porque têm consequiências tidas como positivas para o sistema político, a saber, integração entre atores, incentivos à adaptação e incentivos à sobrevivência. A instituição serve certa função; a instituição se expande porque essa função é vista como positiva; a instituição é cada vez mais capacitada a exercer certa função, e assim com o tempo se consolida. De acordo com a perspectiva relativa à legitimidade, uma vez que a instituição é selecionada de modo contingente, ela será reforçada através de processos de progressiva legitimação, mesmo que outras alternativas institucionais previamente disponíveis tivessem sido mais legítimas (Mahoney 2000, p. 523).

A perspectiva relativa a poder é a que mais interessa para este capítulo. Assim como a perspectiva utilitarista, esta supõe que atores tomam decisões considerando os relativos custos e benefícios gerados pela instituição. Mas a explicação relativa a poder enfatiza o fato de que instituições distribuem custos e benefícios de modo desigual pelo sistema político (Knight 1992), e enfatiza também que atores com diferentes dotações de recursos terão interesses conflitantes no que se refere à reprodução institucional (em outras palavras, perdedores procurarão mudar instituições).

Por que esta perspectiva analítica é a mais adequada para estudar a estabilidade de instituições orçamentárias? Porque importa menos se uma instituição é reproduzida porque benefícios de mudança são baixos (perspectiva utilitarista) ou porque esta instituição tem consequiências tidas como positivas para o sistema político como um todo (perspectiva funcionalista), pois, no fim das contas, a decisão para manter ou eliminar certa instituição é relativa a qual grupo tem poder político para tomar a decisão (ou seja, quem controla a agenda política e tem a maioria necessária para tomar a decisão ou evitar uma decisão indesejada).

Seguirei, portanto, a proposta de Moe (2005), para quem uma boa maneira de operacionalizar empiricamente o conceito de poder político é analisar quem controla a agenda legislativa/agenda de mudanças institucionais. Essa sugestão foi feita originalmente por Bachrach e Baratz (1963), apesar de esses dois textos partirem de perspectivas analíticas bastante diferentes: Moe critica os institucionalistas de escolha racional (Moe 2005, p. 215), Bachrach e Baratz criticam pluralistas como Dahl (1961), pois eles enfatizam que a elite política vence conflitos não necessariamente derrotando explicitamente a oposição, mas sim de modo sub-reptício, evitando que decisões sobre 
propostas da oposição sejam tomadas. Este controle da agenda é o que eles chamam, em outro texto, de "a segunda face do poder" (Bachrach e Baratz, 1962).

Considero o controle da agenda legislativa como um mecanismo através do qual o Executivo brasileiro mantém certas instituições que lhe interessam. Cabe aqui uma explicação sobre mecanismos e sua relevância para o capítulo. Um dos pontos teóricos reconhecidamente controversos e ainda sem clara resolução na literatura é a ausência de mecanismos que explicam adequadamente os processos de estabilidade e mudança institucional (Arretche 2007, p. 149). Para minimizar este problema, proponho, em primeiro lugar, adotar uma definição restrita ${ }^{170}$ de mecanismos. De acordo com Elster (1998, p. 45), “mecanismos são padrões causais que ocorrem freqüentemente e são facilmente reconhecíveis, sendo acionados em condições incertas e com conseqüências indeterminadas. Permitem explicar fenômenos políticos e sociais, mas não que façamos predições sobre eles". Mecanismos, então, teriam um componente funcionalista para a explicação de certo acontecimento. Hedström e Swedberg (1998, p. 7) oferecem uma explicação elegante. Suponhamos ter observado uma relação sistemática entre duas entidades $I$ e $O$. Para explicar a relação entre elas, procuramos um mecanismo, $M$, que sob a ocorrência da causa $I$ gera o efeito ou resultado.

Para o caso aqui estudado, I seriam as critical junctures que colocam a idéia de Orçamento Impositivo na agenda pública; $O$ seria o resultado final relativo a esta instituição orçamentária (no caso, a manutenção do Orçamento Autorizativo) e $M$ seria o mecanismo através do qual os atores políticos com mais poder obtém este resultado desejado.

Assim, um dos modos de ligar a discussão teórica de Mahoney (2000), que enfatiza, entre outros pontos, a importância do poder como mecanismo de reprodução institucional, a casos empíricos que não são path dependent é adotar a sugestão de Moe (2005, p. 223). Este autor explicita duas formas de controle da agenda, sendo a segunda o mecanismo $M$ que considero neste artigo. A primeira trata do controle de agenda no qual um ator nega o status quo a outros atores para que sejam aceitas alternativas que este ator prefere. Este tipo de controle da agenda está relacionado ao "poder de agenda positivo" definido por Cox (2000, p. 173) como a habilidade de levar certo projeto de lei adiante em um certo momento da tramitação legislativa. A segunda forma de controlar a agenda ocorre quando o ator A usa suas prerrogativas sobre a agenda não

\footnotetext{
${ }^{170}$ Isso permite distinguir adequadamente os mecanismos que causam processos de mudança institucional dos processos em si. Para uma definição mais abrangente de "mecanismos", ver Faletti e Lynch (2009).
} 
para negar ao ator B o status quo, mas sim para lhe negar a possibilidade de colocar outras alternativas na agenda legislativa. A próxima seção trata das diversas propostas plausíveis de Orçamento Impositivo no Brasil.

\section{2) Propostas de Orçamento Impositivo e seus efeitos plausíveis}

É importante considerar agora os processos e atores responsáveis por tentativas, bemsucedidas ou não, de mudanças. Conforme o primeiro capítulo explicou longamente, os parlamentares brasileiros têm com a instituição do Orçamento Autorizativo uma relação de "apoio contingente", semelhante ao contingent consent de que Levi (1999) trata. Ou seja, possuem fortes incentivos a apoiar esta instituição desde que ela produza certos efeitos: a execução de emendas orçamentárias individuais e, conseqüentemente, de acordo com o pensamento corrente dos parlamentares, melhores chances para a reeleição ou outros modos de continuar a carreira política. Quanto menos o Orçamento Autorizativo se traduzir em uma razoável execução de emendas orçamentárias individuais, menos incentivos os parlamentares (tanto da coalizão quanto da oposição ao Executivo) terão para apoiar esta instituição ${ }^{171}$.

Como pensar o caso do Orçamento Impositivo à luz disso? Sigo a definição de Pontes Lima (2003, p. 8-9) sobre três modelos possíveis de Orçamento Impositivo e adiciono outro.

No Orçamento Impositivo Extremo (doravante OI Extremo), o governo seria obrigado a executar integralmente a programação orçamentária definida pelo Congresso. Se o presidente não tivesse a arrecadação tributária suficiente para isso, contrairia dívidas para executar os gastos necessários. No Orçamento Impositivo Intermediário (doravante OI Intermediário), o governo poderia deixar de executar certos

\footnotetext{
171 Atualmente, o Orçamento Autorizativo fornece vantagem distributiva para os membros da coalizão, pois permite que parlamentares pertencentes à coalizão governista tenham mais emendas orçamentárias individuais executadas do que os oposicionistas. Segundo (Figueiredo e Limongi, 2008, p. 104, grifo meu), "a execução das emendas individuais é pautada por critérios políticos. As emendas dos deputados filiados a partidos da coalizão do governo têm maiores chances de serem executadas do que as dos demais parlamentares. Contudo, parte das emendas de deputados da oposição também é executada e parte das emendas dos parlamentares que votam com o governo não é executada". Além disso, o Orçamento Autorizativo, de acordo com parte da literatura, fornece vantagem estratégica para Executivo, pois este consegue calibrar a execução orçamentária de modo a extrair maior apoio no plenário para suas propostas legislativas (Alston e Mueller 2005; Pereira, Power e Raile 2009). De qualquer modo, é inegável que o Executivo contingencia dotações e retém liberações financeiras para direcionar o orçamento segundo seus próprios interesses e conveniências (Piscitelli 2006, p. 3), assim como os parlamentares têm mais motivos para se incomodar com esta liberdade quanto menos o Executivo executar emendas individuais.
} 
gastos por falta de receita, desde que justificasse isso para o Legislativo e dele obtivesse autorização explícita. Tratar-se-ia de ter a anuência do Congresso para a não-execução de parte do orçamento ${ }^{172}$. Finalmente, no modelo de Orçamento Impositivo Flexível (doravante OI Flexível), o governo poderia deixar de executar certos gastos por causa da falta de receita, comunicando isso para o Legislativo sem precisar de sua autorização explícita para que isso ocorra. O sistema político brasileiro propôs um quarto tipo de Orçamento Impositivo plausível, no qual fica bastante clara a principal motivação dos parlamentares para apoiar propostas nesse sentido: o Orçamento Impositivo para Emendas Parlamentares (doravante OI Emendas). Neste caso, o Executivo estaria obrigado a executar todas as emendas orçamentárias, individuais e coletivas, propostas por parlamentares.

O Orçamento Impositivo Extremo teria três efeitos plausíveis: i) fortaleceria o Legislativo como ator coletivo, pois este seria responsável por parte da política macroeconômica do país; ii) eliminaria a vantagem distributiva da coalizão em relação à execução de emendas; iii) eliminaria a vantagem estratégica do Executivo em relação ao timing de execução das emendas. O Executivo e membros da coalizão são contrários a alguns tipos de Orçamento Impositivo devido a estes três efeitos plausíveis. É preciso destacar, portanto, que os quatro tipos de Orçamento Impositivo delineados acima são desiguais em relação a estes efeitos, como mostra a tabela 6.1 .

Tabela 6.1: Instituições orçamentárias plausíveis e efeitos para atores políticos

\begin{tabular}{|l|l|l|l|l|l|}
\hline & $\begin{array}{l}\text { Orçamento } \\
\text { Autorizativo }\end{array}$ & OI Extremo & OI Emendas & $\begin{array}{l}\text { OI } \\
\text { Intermediário }\end{array}$ & OI Flexível \\
\hline $\begin{array}{l}\text { Responsabilidade } \\
\text { macroeconômica }\end{array}$ & Executivo & Legislativo & Executivo & Executivo & Executivo \\
\hline $\begin{array}{l}\text { Vantagem } \\
\text { distributiva }\end{array}$ & $\begin{array}{l}\text { Membros da } \\
\text { Coalizão, grande }\end{array}$ & Ninguém & Ninguém & $\begin{array}{l}\text { Parlamentares } \\
\text { da Coalizão, } \\
\text { pequena }\end{array}$ & Ninguém \\
\hline $\begin{array}{l}\text { Vantagem } \\
\text { estratégica }\end{array}$ & $\begin{array}{l}\text { Executivo, } \\
\text { grande }\end{array}$ & Legislativo & $\begin{array}{l}\text { Legislativo, } \\
\text { parcial }\end{array}$ & $\begin{array}{l}\text { Executivo, } \\
\text { pequena }\end{array}$ & $\begin{array}{l}\text { Executivo, } \\
\text { grande }\end{array}$ \\
\hline $\begin{array}{l}\text { Tipo de ator que } \\
\text { deve defender } \\
\text { proposta }\end{array}$ & $\begin{array}{l}\text { Executivo e } \\
\text { Parlamentares } \\
\text { da Coalizão }\end{array}$ & $\begin{array}{l}\text { Parlamentares } \\
\text { da Coalizão e } \\
\text { Oposição, } \\
\text { sobretudo }\end{array}$ & $\begin{array}{l}\text { Parlamentares } \\
\text { da Coalizão e } \\
\text { Oposição, } \\
\text { sobretudo }\end{array}$ & $\begin{array}{l}\text { Parlamentares } \\
\text { da Coalizão e } \\
\text { Oposição }\end{array}$ & Executivo \\
\hline
\end{tabular}

Cabe uma observação em relação à liberdade de execução orçamentária existente no Brasil. Qual parte do orçamento federal seria afetada pelo Orçamento Impositivo? Boa

\footnotetext{
${ }^{172}$ É o mesmo que o mecanismo de rescission do sistema norte-americano, segundo o qual é necessária autorização legislativa para anular crédito orçamentário.
} 
parte do orçamento já é de execução obrigatória, por garantia constitucional ou não ${ }^{173}$. A parte não-obrigatória que seria afetada pelo Orçamento Impositivo engloba novos programas, com ressalvas ${ }^{174}$; a expansão de programas existentes; e investimentos. Ainda que se possa observar que mesmo um OI Extremo não fortaleceria tanto assim o Legislativo, levando em conta que mesmo o Executivo atualmente tem limitada interferência no orçamento (Pontes Lima 2003, p. 8), é claro que esta nova instituição transferiria grande poder aos parlamentares. Há uma parte Y do orçamento em disputa e uma parte $\mathrm{X}$ do orçamento que não é presumida como em disputa pelos atores políticos. Um OI Extremo tornaria essa parte Y do orçamento sob controle do Legislativo e não do Executivo.

Quanto aos efeitos do Orçamento Impositivo Emendas, os parlamentares da oposição seriam beneficiados, pois sumiria a vantagem distributiva dos parlamentares da coalizão, parcialmente beneficiados pelo Executivo quando da execução orçamentária. Algo um pouco diferente ocorreria sob o Orçamento Intermediário. Como o Executivo teria que enviar ao Legislativo pedido de autorização para anular certos créditos orçamentários, sua coalizão parlamentar poderia ser mobilizada e ver suas emendas preservadas enquanto as dos deputados da oposição seriam contingenciadas. Portanto, dentro das opções institucionais elencadas, o Orçamento Intermediário é uma alternativa "second-best" para parlamentares da oposição. O Orçamento Impositivo Flexível, por sua vez, trataria apenas de adicionar uma comunicação formal ao Legislativo a respeito dos cancelamentos e remanejamentos efetuados pelo Executivo. É, praticamente, outro Orçamento Autorizativo ${ }^{175}$. A tabela 6.2 mostra os projetos relativos às alternativas institucionais orçamentárias que ainda tramitam ou um dia tramitaram na Câmara dos Deputados e/ou Senado Federal brasileiro.

\footnotetext{
${ }^{173}$ Por exemplo, despesas com funcionários públicos federais, previdência, transferências para estados e municípios, pagamento de juros, amortização da dívida pública, abono, seguro-desemprego, Lei Orgânica da Assistência Social (LOAS), transferências referentes à Lei Kandir, Sistema Único de Saúde, subsídios e subvenções. Kupfer (2006) e Marques e Mendes (2005) apresentam visão positiva sobre alguns desses gastos, enquanto Velloso (2006) e Nóbrega (2005) criticam-nos duramente.

174 “... pois muitos projetos dependem de investimentos realizados ao longo de vários anos, tornando muito difícil interrompê-los" (Pontes Lima 2003, p. 7).

175 Não contemplo aqui outra alternativa institucional em circulação referente à criação de um comitê interministerial para coordenar a execução orçamentária, mencionada por Barbosa (2006, p. 146), por não haver proposta legislativa neste sentido.
} 
Tabela 6.2: Projetos de Orçamento Impositivo na Câmara dos Deputados e Senado Federal $^{176}$

\begin{tabular}{|c|c|c|c|c|}
\hline Projeto & Autor (a) & Modelo & Expectativa & $\begin{array}{l}\text { Posição do } \\
\text { autor }\end{array}$ \\
\hline $\begin{array}{l}\text { PEC } \\
2 / 2000\end{array}$ & José Alencar (PL) & OI Emendas & Oposição sobretudo & Oposição \\
\hline $\begin{array}{l}\text { PEC } \\
481 / 2001\end{array}$ & Wellington Dias (PT) & OI Emendas & Oposição sobretudo & Oposição \\
\hline $\begin{array}{l}\text { PLP } \\
205 / 2004\end{array}$ & Laura Carneiro (PFL) & OI Emendas & Oposição sobretudo & Oposição \\
\hline $\begin{array}{l}\text { PLP } \\
195 / 2004\end{array}$ & Bernardo Ariston (PMDB) & OI Emendas & Oposição sobretudo & Coalizão \\
\hline $\begin{array}{l}\text { PEC } \\
385 / 2005\end{array}$ & Marcondes Gadelha (PSB) & OI Emendas & Oposição sobretudo & Coalizão \\
\hline $\begin{array}{l}\text { PEC } \\
46 / 2007\end{array}$ & Flaviano Melo (PMDB) & OI Emendas & Oposição sobretudo & Coalizão \\
\hline $\begin{array}{l}\text { PEC } \\
96 / 2007\end{array}$ & $\begin{array}{l}\text { Wandenkolk Gonçalves } \\
\text { (PSDB) }\end{array}$ & OI Emendas & Oposição sobretudo & Oposição \\
\hline $\begin{array}{l}\text { PEC } \\
321 / 2009\end{array}$ & Jair Bolsonaro (PP) & OI Emendas & Oposição sobretudo & Coalizão \\
\hline $\begin{array}{l}\text { PEC } \\
77 / 1999\end{array}$ & Iris Rezende (PMDB) & OI Extremo & Oposição sobretudo & Coalizão \\
\hline $\begin{array}{l}\text { PEC } \\
281 / 2008\end{array}$ & Luiz Carlos Hauly (PSDB) & OI Extremo & Oposição sobretudo & Oposição \\
\hline $\begin{array}{l}\text { PEC } \\
28 / 2000\end{array}$ & Pedro Simon (PMDB) & OI Intermediário & Coalizão/Oposição & Coalizão \\
\hline $\begin{array}{l}\text { PEC } \\
22 / 2000\end{array}$ & $\begin{array}{l}\text { Antônio Carlos Magalhães } \\
\text { (PFL) }\end{array}$ & OI Intermediário & Coalizão/Oposição & Coalizão \\
\hline $\begin{array}{l}\text { PEC } \\
169 / 2003\end{array}$ & Jaime Martins (PL) & OI Intermediário & Coalizão/Oposição & Coalizão \\
\hline $\begin{array}{l}\text { PLP } \\
87 / 2003\end{array}$ & Reginaldo Germando (PP) & $\begin{array}{l}\text { OI Intermediário ligado } \\
\text { à LDO }\end{array}$ & Coalizão/Oposição & Oposição \\
\hline $\begin{array}{l}\text { PLP } \\
218 / 2004\end{array}$ & Yeda Crusius (PSDB) & $\begin{array}{l}\text { OI Intermediário ligado } \\
\text { à CMO }\end{array}$ & Membro da CMO & $\begin{array}{l}\text { Oposição e ex- } \\
\text { relatora setorial } \\
\text { da CMO }\end{array}$ \\
\hline $\begin{array}{l}\text { PL } \\
4786 / 2005\end{array}$ & Bismarck Maia (PSDB) & $\begin{array}{l}\text { OI para Área de } \\
\text { Transportes }\end{array}$ & $\begin{array}{l}\text { Partido ou } \\
\text { parlamentar } \\
\text { interessado em } \\
\text { Transportes }\end{array}$ & $\begin{array}{l}\text { Oposição e ex- } \\
\text { relator setorial } \\
\text { da CMO }\end{array}$ \\
\hline
\end{tabular}

Fontes: Câmara dos Deputados e Senado Federal brasileiro.

Apenas dois projetos de OI Extremo foram propostos, um por um senador da coalizão, outro por um deputado da oposição. Oito propostas de OI Emendas circularam nas casas legislativas, quatro por membros da coalizão, quatro por membros da oposição.

Três projetos de OI Intermediário foram aventados, todos por membros da oposição. Um deles, de Reginaldo Germando, propõe a obrigatoriedade de o Executivo gastar o que o Legislativo propõe na Lei de Diretrizes Orçamentárias, a primeira etapa

\footnotetext{
${ }^{176}$ Retirei da tabela o Projeto de Emenda Constitucional 565/2006, da Câmara dos Deputados, por ser apenas a continuação da PEC 22/2000 aprovada pelo Senado Federal.
} 
do processo orçamentário anual. Yeda Crusius, do PSDB, propôs que a Comissão Mista de Orçamento determinasse as verbas a serem obrigatoriamente gastas pelo Executivo, podendo ser anuladas mediante autorização legislativa - ou seja, um OI Intermediário ligado a esta comissão. Crusius havia sido relatora setorial da área de Educação, Cultura, Esporte, Ciência e Tecnologia na Comissão Mista de Orçamento em 1996, o que indica seu envolvimento na comissão e o interesse em dar mais poder aos postos institucionais da CMO. Bismarck Maia, também do PSDB, propôs um OI Intermediário específico para a área de Transportes. Maia foi relator setorial da área de Saúde na CMO em 2004, algo que nada tem a ver com sua proposta, mas indica interesse do parlamentar por assuntos orçamentários.

Finalmente, três propostas “ortodoxas" de OI intermediário foram sugeridas por membros da coalizão, duas em 2000 e uma em 2003. Destas, vale destacar o Projeto de Emenda Constitucional 22/2000 do senador Antônio Carlos Magalhães, líder notório do PFL na Bahia, falecido em 2007 . Por se tratar do projeto de Orçamento Impositivo que mais longe chegou dentro do Legislativo, tendo sido aprovado no Senado Federal e hoje tramitando na Câmara dos Deputados como o PEC 565/2006, o resto do capítulo será focado nele.

A partir das duas colunas à extrema direita da tabela 6.2, podemos observar que parlamentares da coalizão e da oposição são igualmente responsáveis por propostas de Orçamento Impositivo. Este resultado misto é pouco compreensível sob a perspectiva teórica de "perdedores" e "vencedores" com desenhos institucionais quanto com a perspectiva de que os atores agirão de acordo com seus interesses racionais: apenas deputados e senadores da oposição ao governo deveriam, nesta linha analítica, propor o fim do Orçamento Autorizativo.

Mudar instituições requer esforço, tempo, influência política e capacidade de persuasão incomuns. Freqüentemente exige um entrepreneur relativamente forte para que haja chances reais de superar os obstáculos à mudança institucional. A próxima seção dedica-se a explicar por que o entrepreneur Antônio Carlos Magalhães, senador da coalizão durante a maior parte dos governos de Fernando Henrique Cardoso (19952002), foi o principal proponente do Orçamento Impositivo nos últimos vinte anos no Brasil e como essa idéia, apesar de mobilizar o apoio de boa parte dos senadores, esbarrou no eficaz controle da agenda legislativa pelo Executivo. 


\section{3) Controle da agenda e um entrepreneur do Orçamento Impositivo}

Esta seção tratará de três temas. O primeiro considera rapidamente como as propostas de Orçamento Impositivo começaram a circular na agenda pública brasileira; em seguida, analisa como o Executivo busca controlar a agenda legislativa no Brasil e, por fim, como o empreendedor político Antônio Carlos Magalhães, senador conservador, teve relativo sucesso em burlar esse controle institucional do Executivo com sua proposta de Orçamento Impositivo.

A circulação de idéias institucionais - sobretudo as "heterodoxas", que buscam oferecer alternativas que distribuem recursos e poder de modo bastante diferente das instituições vigentes - costuma se beneficiar de critical junctures (Katznelson 2003), associadas, no caso desta tese, a escândalos de corrupção. À primeira vista, o caso do Orçamento Impositivo parece ser típico dessa dinâmica. A escassa literatura sobre instituições orçamentárias no Brasil atribui a circulação de propostas de Orçamento Impositivo tanto a escândalos de corrupção orçamentária (Figueiredo e Limongi 2008, p. 18) quanto a ações do Executivo que podem ser vistas como arbitrárias ou atípicas em um processo orçamentário saudável (Pontes Lima 2003, p. 11).

No entanto, ambas as perspectivas são incompletas. A primeira Comissão Parlamentar de Inquérito no Congresso que investigou corrupção orçamentária, entre 1993 e 1994, não incluiu, entre 23 sugestões de reforma institucional, a idéia do Orçamento Impositivo. Embora tenha apoiado que a "elaboração das propostas orçamentárias" ocorresse "em conjunto e simultaneamente pelo Executivo e Legislativo", o principal objetivo da comissão parecia ser livrar o processo orçamentário de um cartel corrupto, com pouca atenção para o equilíbrio da relação ExecutivoLegislativo neste aspecto.

Mas, desde 1999, dezesseis propostas de Orçamento Impositivo circularam tanto na Câmara dos Deputados quanto no Senado Federal. Um ofício do deputado federal Paulo Bernardo (então presidente da Comissão Mista de Orçamento), endereçado em 1/3/2005 para os presidentes da Câmara dos Deputados e Senado Federal tratava de diversos temas relativos à reforma orçamentária, entre eles "execução orçamentária e Orçamento Impositivo". Bernardo diagnosticou um "distanciamento da execução orçamentária em relação à autorização legislativa expressa na lei orçamentária, dada a idéia de que o orçamento aprovado tem caráter autorizativo" e um "contingenciamento discricionário da execução orçamentária”. Propôs, entre outras medidas, estabelecer na 
Lei de Diretrizes Orçamentárias ${ }^{177}$ (LDO) “critérios e fórmulas que reduzam o poder discricionário do Executivo" e tornar obrigatória a execução de despesas discricionárias aprovadas, desde que atingida a meta fiscal (nominal) prevista na LDO - em outras palavras, um Orçamento Impositivo dependente de certo equilíbrio fiscal a ser definido anteriormente pelo Congresso e Executivo na LDO.

A partir deste ofício, uma comissão de deputados e senadores foi encarregada de organizar reuniões com membros do Executivo e parlamentares em geral sobre diversos itens da reforma orçamentária. O Orçamento Impositivo foi discutido sobretudo como o que chamei de "OI Emendas" - uma proposta que tornasse obrigatória a execução de emendas orçamentárias propostas por parlamentares, sem se preocupar com o resto do orçamento $^{178}$.

Isto não é surpreendente: afinal, trata-se de uma mudança enorme no arcabouço institucional brasileiro. O Orçamento Impositivo, por ser, em sua versão mais pura, uma proposta de emenda constitucional, exige o apoio de $60 \%$ dos membros de cada casa legislativa no Brasil em duas votações. O único ator político que possui recursos suficientes para mobilizar tantos parlamentares em torno de uma proposta de emenda constitucional é o Executivo. Portanto, já que uma proposta de OI não interessa ao Executivo, quem poderia propô-la? Apenas um entrepreneur com grande força política para levar adiante a proposta. No caso do Orçamento Impositivo no Brasil, o senador Antônio Carlos Magalhães (PFL-BA) foi este empreendedor.

Por que Magalhães propôs o Orçamento Impositivo em 2000? Embora seja impossível saber ao certo, há três argumentos plausíveis que podem explicar a ação do senador: o mau relacionamento dentro da coalizão, uma estratégia de risk aversion e o Orçamento Impositivo como "proposta-bandeira", apenas simbólica, pois Magalhães não acreditaria em seu sucesso.

A primeira está relacionada ao seu turbulento relacionamento com a coalizão governista a partir de 1999. Embora Magalhães tivesse um bom relacionamento, em geral, com Fernando Henrique Cardoso desde sua eleição em 1994, a partir de 1999 o senador azedou relações com parte da coalizão. Vale citar o próprio presidente para explicar um pouco da conjuntura política à época: "No início de 2000 , havia nuvens

\footnotetext{
177 Trata-se da primeira versão do orçamento enviado ao Congresso pelo Executivo até 30 de junho de cada ano. Os parlamentares interferem no orçamento a partir dela.

${ }^{178}$ Agradeço funcionários da Comissão Mista de Orçamento por me darem acesso às atas das reuniões realizadas por esta comissão sobre reforma orçamentária em 2005. Essas atas foram essenciais para a reconstrução das idéias em seu contexto temporal.
} 
cinzentas no horizonte da política. A tensão entre PMDB e PFL, que vinha se arrastando desde 1999, ora tomava o aspecto de uma disputa entre o presidente do Senado, Antonio Carlos Magalhães, do PFL, e o da Câmara, Michel Temer, do PMDB, ora surgia como um choque direto entre o líder do PMDB no Senado, Jader Barbalho, e o presidente da Casa. Lançou-se mão sem reservas das armas habituais da política de caciques. Brandiram-se 'dossiês' antigos para desmoralizar o líder peemedebista que se candidatara a substituir o presidente do Senado, pois em fevereiro haveria renovação das Mesas, sem possibilidade de reeleição dos ocupantes" (Cardoso 2006, p. 330)

Magalhães não era um político com experiência e interesse por assuntos orçamentários (Dantas Neto 2006). É plausível imaginar que a proposta tenha tido a intenção de denunciar a suposta má condução da política macroeconômica pelo governo de Cardoso. Ou, então, apenas para irritar o presidente. Propostas vindas de Magalhães com essa intenção, de acordo com Cardoso, não eram raras: "No início de 1999, o senador ACM veio com uma nova proposta: um Fundo de Combate à Pobreza, matéria contra a qual ninguém em sã consciência pode se opor, que, contudo, em momento de apertar os cintos e de rigidez orçamentário, se torna um problema adicional para o governo. A proposta me pegou de surpresa. Respondi que nossa administração já tinha uma programação social intense, pois era evidente a estocada: o governo só se preocupa com o mercado e não com os pobres" (Cardoso 2006, p. 490-495).

A segunda explicação para a propositura do Orçamento Impositivo por Magalhães é que se tratou de uma estratégia racional de aversão a risco (risk aversion). Ou seja, Magalhães propos Orçamento Impositivo em grande parte para diminuir a incerteza decorrente da mudança de presidente em 2002. Se com Cardoso ele tinha relação razoável, não fazia idéia de como um novo presidente seria - tanto José Serra (PSDB) quanto Luiz Inácio Lula da Silva (PT) poderiam ser desastrosos para Magalhães. Assim, a proposta de mudança institucional pode ser vista como uma estratégia para reduzir a incerteza que naturalmente viria com um novo presidente - e a conseqüente mudança da relação entre certos partidos e parlamentares com o Executivo).

Segundo Elster (2007, p. 191), um ato é racional se preenche três requisitos :i) o ato deve ser "optimal" consideradas certas crenças; ii) as crenças devem estar bem fundamentadas em evidências empíricas; iii) essas evidências empíricas devem ter sido colhidas através de investimentos de tempo e recursos para se informar bem. Há duas condições prévias para isto, no entanto. As preferências do ator devem ser transitivas e 
completas. Elster (2007, p. 194) define "preferências completas" do seguinte modo. Se há dois resultados institucionais possíveis, o ator deve conseguir afirmar se prefere o primeiro ao segundo, o segundo ao primeiro, ou a indiferença entre os dois. Caso não consiga responder deste modo, não saberá determinar qual é a melhor opção. Neste sentido, a tabela 6.3 abaixo mostra que, quando se trata de instituições orçamentárias, Magalhães tem, sim, preferências completas.

Tabela 6.3: Payoffs para Magalhães de Orçamento Autorizativo x Orçamento Impositivo

\begin{tabular}{|l|l|l|}
\hline & Magalhães como líder partidário & $\begin{array}{l}\text { Magalhães como líder do } \\
\text { Legislativo }\end{array}$ \\
\hline $\begin{array}{l}\text { Orçamento Autorizativo } \\
\text { (como membro da coalizão) }\end{array}$ & Alto, pois ajuda a liberar emendas & $\begin{array}{l}\text { Médio, pois Legislativo } \\
\text { influencia apenas parte do } \\
\text { orçamento }\end{array}$ \\
\hline $\begin{array}{l}\text { Orçamento Autorizativo } \\
\text { (como membro da oposição) }\end{array}$ & $\begin{array}{l}\text { Baixíssimo, embora não tenha } \\
\text { certeza absoluta disso } \\
\text { Baixo, pois dificilmente } \\
\text { seria presidente do Senado } \\
\text { contra a vontade da } \\
\text { coalizão }\end{array}$ \\
\hline Orçamento Impositivo & $\begin{array}{l}\text { Baixo, pois deputados não } \\
\text { precisariam de Magalhães para ter } \\
\text { emendas executadas }\end{array}$ & $\begin{array}{l}\text { Altíssimo, pois o } \\
\text { Legislativo tomaria } \\
\text { decisões macroeconômicas } \\
\text { relevantes }\end{array}$ \\
\hline
\end{tabular}

Por que a propositura de um Orçamento Impositivo por Magalhães poderia ser uma estratégia de risk aversion? Porque ser da oposição sob o Orçamento Autorizativo traria dois resultados possíveis, a julgar pela experiência dos dois mandatos de Fernando Henrique Cardoso na presidência. Em primeiro lugar, Magalhães, como líder da oposição, teria acesso a muito menos pork, assim como o PT teve sob Cardoso. Talvez Magalhães pudesse ter acesso a uma quantidade satisfatória de pork, mas a um "preço" mais caro: teria que votar antes com o governo na expectativa de talvez receber depois. Ou seja, ficar sob Orçamento Autorizativo traria dois resultados arriscados para a liderança de Magalhães, enquanto a alternativa institucional - Orçamento Impositivo enfraqueceria-no como lider partidário, mas o fortaleceria muito como líder legislativo.

Outra possibilidade é que Magalhães tenha agido estrategicamente, propondo algo que saberia ser impossível de passar, mas usando isto para barganhar em torno de outros projetos de seu interesse ou mesmo uma versão atenuada de Orçamento Impositivo, menos agressiva em relação ao Executivo. Sabia que sua proposta teria pouca ou nenhuma chance de se tornar lei, mas, por motivos diversos, interessava ao senador ser visto como o proponente do orçamento impositivo. Ao analisar projetos de lei propostos pelo Executivo, Diniz (2005, p. 342) afirma que "o encaminhamento de 
uma proposta ao Congresso não deve ser interpretado como sendo, necessariamente, a preferência sincera do seu proponente. A iniciativa pode ter sido tomada para passar uma determinada imagem à opinião pública ou em resposta a grupos de pressão. Assim, a não-aprovação - que não seja rejeição - não deve ser tomada de antemão como indicador de fracasso". Devemos avaliar a tramitação de projetos de orçamento impositivo no Brasil - o de Magalhães, em especial - com isso em mente, considerando também que as três explicações não se anulam: são complementares.

Quais obstáculos institucionais um empreendedor como Magalhães enfrentaria para fazer aprovar sua proposta de Orçamento Impositivo? Seriam consideráveis. Após a Constituição de 1988, o sistema político brasileiro já foi descrito como repleto de “dificuldades para que o presidente passe sua agenda pelo Congresso" (Ames 2002, p. 213), mas também como tendo "um padrão consistente de governo versus oposição, com razoável disciplina entre os diversos partidos parceiros do governo e alta disciplina por parte da oposição" (Santos 2002, p. 257-258). Este capítulo não pretende realizar discussões sobre essa literatura. No entanto, através da descrição a seguir sobre como ocorre o controle da agenda legislativa pelo Executivo, a filiação à segunda visão tornase clara. Os parágrafos a seguir retomam uma discussão traçada no primeiro capítulo.

A Constituição de 1988 define que o processo deliberativo é de competência das duas Casas Legislativas - Câmara dos Deputados e Senado Federal - , sendo que a primeira tem primazia como instância deliberativa. Isto significa que as propostas apresentadas pelo Executivo devem iniciar sua tramitação pela Câmara. Ao Senado cabe a função de exercer um papel de revisor das matérias aprovadas pela Câmara, devendo esta se pronunciar, em última instância, sobre as eventuais alterações feitas pelo Senado. A proposição do Executivo aprovada na Câmara é enviada para deliberação do Senado.

A Câmara dos Deputados se organiza em torno de algumas instâncias fundamentais para o encaminhamento e a deliberação dos trabalhos legislativos. São as comissões permanentes, a Mesa Diretora das Casas Legislativas, e o Colégio de Líderes. As propostas enviadas como projetos de lei devem ser deliberadas, em cada uma das Casas, em primeira instância nas comissões permanentes para, posteriormente serem deliberadas pelo plenário. Essas comissões são integradas por parlamentares de acordo com critérios de proporcionalidade partidária e têm áreas específicas de jurisdição. Os trabalhos das comissões são comandados por seus presidentes, encarregados de indicarem relatores para as matérias e de conduzirem o processo de deliberação 
enquanto a matéria estiver no âmbito das comissões. Este ponto, sobretudo, nos interessará neste capítulo.

As Mesas Diretoras são os órgãos que administram as Casas Legislativas e dirigem grande parte do processo legislativo. Os cargos da Mesa (Presidente, Vicepresidentes e Secretários) são distribuídos pelo princípio da proporcionalidade partidária. Os regimentos internos definem uma série de regras para eleição dos membros da Mesa, porém, na prática, sabe-se que a escolha de tais membros obedece a critérios políticos. Em geral, a bancada partidária com maior representação na Casa Legislativa fica com a presidência da Mesa. A presidência é um cargo de suma importância, pois, além de estar na linha sucessória para substituir o chefe do Executivo, é ela quem comanda os trabalhos legislativos, definindo a Ordem do Dia, isto é, estabelecendo quais projetos serão apreciados e esclarecendo questões procedimentais que são importantes para a condução do processo deliberativo. A eleição da Mesa ocorre a cada dois anos.

Outra instância institucional, fundamental para as deliberações nas Casas Legislativas, é o Colégio de Líderes, formado pelos líderes das bancadas partidárias. Aos Líderes Partidários cabem, entre outras atribuições, encaminhar as votações nas comissões e no plenário e indicar os membros que irão compor as comissões, dirimir dúvidas, divergências e estabelecer acordos no andamento das matérias. Os líderes são eleitos por suas respectivas bancadas partidárias e a Presidência da República pode indicar um deputado para exercer a Liderança do Governo.

A composição das comissões permanentes depende da representação de cada partido nas casas legislativas. Como no Brasil vigora um multipartidarismo, onde é praticamente impossível que um único partido detenha maioria absoluta, o partido governista e sua base de apoio não terão a presidência de todas as comissões permanentes.

Cabe ao presidente da comissão indicar o parlamentar que será o relator da matéria. O relator é figura-chave no processo deliberativo, pois é com base no seu parecer que a matéria será colocada a voto. O parecer pode sugerir que o projeto seja aprovado na íntegra; pode apresentar emendas, isto é, alterar a proposta original; ou pode apresentar um substitutivo que é, muitas vezes, um novo projeto. Um presidente de comissão pouco simpático à proposta do governo poderá, por exemplo, indicar um parlamentar também pouco favorável à proposta para relatar a matéria. As resistências 
ao projeto começariam a se manifestar antes mesmo da matéria ser posta a voto, seja na comissão ou no plenário.

Digamos que o projeto tenha sido relatado por alguém favorável à matéria proposta pelo governo e que não apresentou modificações ao texto original. O parecer é votado na comissão. Se aprovado, vai a plenário. Se o plenário for o da Câmara dos Deputados, o projeto será remetido para apreciação dos senadores. No Senado, se o projeto for rejeitado será arquivado. Se alterado, voltará à Câmara para apreciação das alterações feitas. Se aprovado tal qual enviado pelo Senam tedo, será encaminhado para sanção presidencial. Se a Câmara não concorda com as alterações, permanece seu texto, que será encaminhando para sanção presidencial.

Uma vez encaminhado à sanção, se o Executivo concorda com o texto aprovado pelo Legislativo, ele é sancionado. Se não, poderá vetá-lo totalmente, ou apenas parcialmente, isto é, promulga apenas partes do projeto de lei. Ao Legislativo caberá dar a última palavra quanto aos vetos. Poderá manter o veto ou derrubá-lo, desde que aprovado pela maioria.

Projetos de emenda constitucional, como é o caso do Orçamento Impositivo, seguem regras um pouco diferentes. Quando iniciado no Senado, o projeto vai à Comissão de Constituição e Justiça e necessita da aprovação em dois turnos por $60 \%$ do plenário - 49 dos 81 senadores.

Notamos, com a descrição acima, que são consideráveis os obstáculos à frente de Antônio Carlos Magalhães e sua proposta de Orçamento Impositivo Intermediário. A seguir, um relato de como o senador conseguiu fazer de sua proposta a mais bemsucedida do período pós-1988. O projeto passou no Senado Federal, mas foi ser barrado pela coalizão governista na Comissão de Constituição e Justiça da Câmara dos Deputados em 2006, um ano antes de Magalhães morrer.

\section{Um empreendedor contra dois desenhos institucionais: o relativo sucesso de}

\section{Magalhães}

O argumento teórico inicial do capítulo propõe que o controle da agenda legislativa pelo Executivo é o mecanismo através do qual este ator político exerce poder e, assim, mantém certas instituições estáveis. No caso do "Orçamento Autorizativo", interessa ao Executivo que esta instituição permaneça como está pois com ela obtém três vantagens em relação ao Congresso: a condução da política macroeconômica do país; a vantagem 
distributiva da coalizão liderada pelo Executivo em relação à execução de emendas e, por fim, a vantagem estratégica do Executivo em relação ao timing de execução das emendas.

Portanto, podemos esperar que o Executivo mobilize diversos recursos institucionais à sua disposição, alguns dos quais foram elencados na seção anterior, para bloquear a tramitação legislativa de propostas de Orçamento Impositivo. Se o governo tem poucas condições de impedir que esse tipo de proposta entre na agenda pública ${ }^{179}$, consegue controlar muito bem a tramitação da proposta uma vez que ela seja oficializada no parlamento. Para isso, utiliza-se de alguns dos mecanismos com os quais busca fazer aprovar suas leis, como: o controle da Mesa Diretora; a alocação de ministérios e benesses para líderes partidários mais ou menos de acordo com a representação dos partidos no Legislativo; a indicação de relatores para projetos especialmente sensíveis a interesses do Executivo nas comissões da Câmara dos Deputados e Senado Federal, entre outros ${ }^{180}$.

Qual o destino das dezesseis propostas de Orçamento Impositivo ${ }^{181}$ que circularam pela Câmara dos Deputados e Senado Federal desde 1988? Uma foi devolvida ao parlamentar que o apresentou por falta de assinaturas; outra, proposta por Magalhães, foi aprovada no Senado Federal e tramita na Câmara dos Deputados; seis propostas foram formalmente arquivadas e as oito restantes foram apensadas, durante diversas etapas do processo legislativo, ao projeto de Magalhães ${ }^{182}$.

\footnotetext{
${ }^{179}$ Isto é verdade mesmo considerando que o Executivo tem razoável controle sobre a instalação e o alcance de comissões investigativas (Taylor e Buranelli 2007, p. 70). Tais comissões podem estimular, ainda que indiretamente, a proposição de projetos para instalar algum tipo de Orçamento Impositivo no país. Shepsle (2003, p. 313), ao contrário, acredita que políticos incumbentes conseguem controlar muito bem a agenda de assuntos públicos devido a dificuldades de comunicação dos losers políticos com os eleitores.

${ }^{180}$ Poderíamos adicionar, caso o Executivo tenha sucesso em formar um "cartel parlamentar" nos moldes de Amorim Neto, Cox e McCubbins (2003, p. 550), o controle do plenário e das comissões por uma maioria de parlamentares pertencente à coalizão governista.

181 Os projetos de emenda constitucional 22/2000 e 565/2006 são o mesmo em tempos diferentes: o segundo é o projeto de Magalhães durante sua tramitação na Câmara dos Deputados, após ser aprovado no plenário do Senado Federal. Por isso, considero apenas o PEC 22/2000 na tabela.

182 A tramitação conjunta de projetos geralmente ocorre quando projetos de lei tratam de assuntos correlatos. Qualquer parlamentar pode pedir o apensamento de um projeto a outro, assim como o contrário. Tantas propostas foram provavelmente apensadas à de Magalhães porque, a partir de certa altura, tornou-se claro que esta proposta era defendida com veemência por um forte líder político - assim, portanto, teria mais chance de passar do que outras. Além disso, quando ocorre tramitação conjunta, a proposta oriunda do Senado tem precedência sobre as da Câmara, assim como a proposta mais antiga tem precedência sobre as mais recentes. Ver artigos 258-260 do Regimento Interno do Senado Federal e artigos 142-143 do Regimento Interno da Câmara dos Deputados.
} 
Tabela 6.4: Situação atual das propostas de Orçamento Impositivo no Brasil

\begin{tabular}{|c|c|c|c|}
\hline Projeto & $\begin{array}{l}\text { Autor e sua posição em } \\
\text { relação ao Executivo }\end{array}$ & Situação Atual & $\begin{array}{l}\text { Apensado à PEC } \\
\text { 22/2000? }\end{array}$ \\
\hline PEC 77/1999 & Iris Rezende (coalizão) & - & $\begin{array}{l}\text { Sim, após relatório } \\
\text { favorável de Edison } \\
\text { Lobão na CCJ }\end{array}$ \\
\hline PEC 2/2000 & José Alencar (oposição) & $\begin{array}{l}\text { Arquivado ao fim da legislatura, } \\
\text { com relatório favorável na CCJ }\end{array}$ & $\begin{array}{l}\text { Houve tentativa, } \\
\text { mas Alencar evitou }\end{array}$ \\
\hline PEC 28/2000 & Pedro Simon (coalizão) & - & $\begin{array}{l}\text { Sim, após relatório } \\
\text { favorável da CCJ }\end{array}$ \\
\hline PEC 22/2000 & $\begin{array}{l}\text { Antônio Carlos Magalhães } \\
\text { (coalizão) }\end{array}$ & Tramita na CCJ da Câmara & Não se aplica \\
\hline $\begin{array}{l}\text { PEC } \\
481 / 2001\end{array}$ & Wellington Dias (oposição) & Arquivado por falta de assinaturas & - \\
\hline $\begin{array}{l}\text { PEC } \\
169 / 2003\end{array}$ & Jaime Martins (coalizão) & - & $\begin{array}{l}\text { Sim, mas relator } \\
\text { governista na CCJ } \\
\text { não apresentou } \\
\text { relatório }\end{array}$ \\
\hline PLP 87/2003 & $\begin{array}{l}\text { Reginaldo Germando } \\
\text { (oposição) }\end{array}$ & $\begin{array}{l}\text { Arquivado com relatório contrário } \\
\text { de governista J. E. Cardozo na CCJ }\end{array}$ & - \\
\hline $\begin{array}{l}\text { PLP } \\
218 / 2004\end{array}$ & Yeda Crusius (oposição) & Arquivado sem relator indicado & - \\
\hline $\begin{array}{l}\text { PLP } \\
205 / 2004\end{array}$ & Laura Carneiro (oposição) & Arquivado sem relator indicado & - \\
\hline $\begin{array}{l}\text { PLP } \\
195 / 2004\end{array}$ & Bernardo Ariston (coalizão) & Arquivado sem relator indicado & - \\
\hline $\begin{array}{l}\mathrm{PL} \\
4786 / 2005\end{array}$ & Bismarck Maia (oposição) & $\begin{array}{l}\text { Arquivado após relatora governista } \\
\text { na Comissão de Finanças não } \\
\text { apresentar relatório }\end{array}$ & - \\
\hline $\begin{array}{l}\text { PEC } \\
385 / 2005\end{array}$ & Marcondes Gadelha (coalizão) & - & $\begin{array}{l}\text { Sim, sem relator } \\
\text { indicado }\end{array}$ \\
\hline PEC 46/2007 & Flaviano Melo (coalizão) & - & $\begin{array}{l}\text { Sim, sem relator } \\
\text { indicado }\end{array}$ \\
\hline PEC 96/2007 & $\begin{array}{l}\text { Wandenkolk Gonçalves } \\
\text { (oposição) }\end{array}$ & - & $\begin{array}{l}\text { Sim, sem relator } \\
\text { indicado }\end{array}$ \\
\hline $\begin{array}{l}\text { PEC } \\
281 / 2008\end{array}$ & Luiz Carlos Hauly (oposição) & - & $\begin{array}{l}\text { Sim, sem relator } \\
\text { indicado }\end{array}$ \\
\hline $\begin{array}{l}\mathrm{PEC} \\
321 / 2009\end{array}$ & Jair Bolsonaro (coalizão) & - & $\begin{array}{l}\text { Siim, sem relator } \\
\text { indicado }\end{array}$ \\
\hline
\end{tabular}

Fontes: Câmara dos Deputados e Senado Federal; para posição dos autores em relação à coalizão liderada pelo Executivo, ver Figueiredo (2007, p. 190).

A partir da tabela 6.4, tornam-se evidentes os mecanismos usados pela coalizão liderada pelo Executivo para evitar a aprovação de propostas de Orçamento Impositivo. A coalizão pode não indicar relator para o projeto $^{183}$, assim impedindo sua votação pela comissão (projetos 218/2004; 205/2004; 195/2004; 385/2005; 46/2007; 96/2007;

${ }^{183}$ Não é a "coalizão" que indica diretamente os relatores dos projetos, mas sim os presidentes das comissões. 
281/2008; 321/2009); pode indicar um relator que proponha a rejeição da proposta pela comissão (projetos 87/2003, 4786/2005); pode indicar um relator que não apresente relatório, assim impedindo a votação da proposta pela comissão (projeto 169/2003). No caso de doze propostas, o poder do Executivo como líder da coalizão se exerce silenciosamente.

Três propostas, além da de Magalhães, conseguiram relatório favorável na Comissão de Constituição de Justiça do Senado Federal. Essas propostas foram apensadas à PEC 22/2000, aprovada em 2006 pelo plenário do Senado Federal e atualmente em tramitação na Câmara dos Deputados.

Mas uma proposta de Orçamento Impositivo, por alterar tão profundamente o desenho institucional do país, precisa de um empreendedor político (entrepreneur) forte e, ao menos aparentemente, sem medo de colecionar inimigos políticos no Executivo. Trata-se do senador Antônio Carlos Magalhães. Os outros proponentes de OI são, como Mintrom (1997, p. 741) afirma, "parlamentares que usam sua posição institucional para tentar inovar sem que isto seja acompanhado pelo charme do verdadeiro empreendedorismo".

Há quatro dificuldades claras para Magalhães. A primeira é a natureza da proposta. Por ser projeto de emenda constitucional, exige maioria "maior" no plenário do que projetos de lei ou projetos de lei complementar ${ }^{184}$. A segunda é o conteúdo da proposta: o Executivo, líder da coalizão majoritária no Legislativo, tem fortes incentivos para ser contra a idéia do Orçamento Impositivo Intermediário de Magalhães. A terceira se refere a uma prerrogativa institucional: o senador não pode, sozinho, pedir urgência para que o projeto seja deliberado rapidamente pelo plenário ${ }^{185}$. Por fim, a quarta dificuldade é também relacionada à natureza da proposta. Por se tratar de projeto de emenda constitucional, tem que ser aprovado no plenário tanto da Câmara dos Deputados quanto do Senado Federal. Magalhães tinha pouquíssima influência pessoal na Câmara, embora fosse um líder reconhecido no Senado.

No entanto, o senador apresenta no mínimo quatro vantagens em relação a outros parlamentares que propuseram algum tipo de Orçamento Impositivo. Era um ator

\footnotetext{
${ }^{184}$ Souza (2008, p. 810) afirma que parlamentares trabalham junto com membros do Executivo em alguns projetos de emenda constitucional, mostrando relação mais nuançada do que a divisão LegislativoExecutivo indica.

${ }^{185} \mathrm{O}$ requerimento de urgência é um dispositivo comumente usado pelo Executivo para acelerar a tramitação de projetos que lhe interessam. No caso de projetos propostos por senadores, o requerimento de urgência requer a concordância de, no mínimo, $25 \%$ dos membros ou líderes partidários que representam esse número. Ver artigos 336 a 344 do Regimento Interno do Senado Federal.
} 
político influente e relativamente independente do Executivo; de 2005 a 2006, foi presidente da Comissão de Constituição e Justiça do Senado Federal (doravante $\mathrm{CCJ} / \mathrm{SF}$ ), tendo a prerrogativa de indicar o senador que relataria sua PEC nesta comissão, a mais importante da casa legislativa; o partido de Magalhães, PFL, era muito forte na $\mathrm{CCJ} / \mathrm{SF}$, o que significa que o parecer do relator indicado por Magalhães teria boas chances de ser aprovado; por fim, o projeto do senador era de OI Intermediário e não Extremo, algo que alienaria, certamente, a imensa maioria dos parlamentares pertencentes à coalizão governista.

O que a proposta de OI Intermediário Magalhães dizia? Era uma típica proposta de governo ou de oposição? A PEC 22/2000 tinha seis principais pontos: 1) encerrar a sessão legislativa somente após a deliberação sobre o projeto de lei orçamentária anual; 2) proibir a ocorrência de programação genérica nas leis orçamentárias - os projetos "guarda-chuvas"; 3) incluir novas programações na lei orçamentária somente após adequadamente contempladas com dotações já em execução; 4) tornar de execução obrigatória a lei orçamentária; caso o presidente desobedeça, será configurado crime de responsabilidade; 5) vedar a ocorrência de "receitas condicionadas" nas leis orçamentárias; 6) alterar os prazos para o Congresso apreciar os projetos de Lei Orçamentária Anual, Lei de Diretrizes Orçamentárias e Plano Plurianual.

O quarto ponto, sem dúvida, é o mais importante do projeto e o que alteraria profundamente o processo orçamentário brasileiro. Se o presidente solicitasse cancelamento ou contingenciamento total ou parcial de algum projeto previsto no orçamento, esta solicitação tramitaria no Congresso Nacional em regime de urgência. Caso o Congresso não deliberasse sobre esta solicitação em até 30 dias, ela seria considerada aprovada - ou seja, caberia aos parlamentares se mobilizar para derrotar cancelamentos do Executivo, o que indica que o status quo não seria tão desfavorável ao presidente como se poderia imaginar.

Chama atenção, no entanto, o fato de Magalhães incluir que a mudança institucional entraria em vigor "no primeiro dia útil do segundo ano subseqüente ao de sua publicação". Como o senador propôs o projeto em junho de 2000, é razoável imaginar que ele esperava sua aprovação em, no mínimo, 2001. Ora, o segundo ano depois de 2001 é 2003, com novo governo. É o inverso das sunset provisions mecanismo no processo legislativo norte-americano que faz uma lei expirar após certo período (Sinclair 2007, p. 94) - e é, também, um fortíssimo indicador de que Magalhães propôs o PEC 22/2000 como uma estratégia de risk aversion, conforme defini acima. 
Como afirma Kingdon (1995, p. 181), a tenacidade recompensa o empreendedor político. Parada no Senado Federal por cinco anos, a PEC 22/2000 começou a ter importância real, para além de discursos de Magalhães e seus asseclas em plenário, quando o senador assumiu a presidência da CCJ/SF em 2005. Ele já era um líder da oposição ao presidente esquerdista Luiz Inácio Lula da Silva, do Partido dos Trabalhadores. Considerando que coalizões legislativas lideradas pelo Executivo tendem a "alocar a seus membros os postos oficiais que contêm prerrogativas de controlar a agenda, como ministérios, presidências de comissões etc." (Amorim Neto, Cox e McCubbins 2003, p. 551), foi estranho Magalhães conseguir este cargo.

Sobretudo porque a CCJ/SF é tida como uma das mais importantes e disputadas na estrutura do sistema de comissões brasileiro e uma grande quantidade de senadores com carreiras consolidadas buscam integrá-la (Lemos e Ranincheski 2008, p. 88 e 114). É, sem dúvida, a principal comissão do Senado: Ricci (2008, p. 252, citando Lemos 2006) afirma que, em 1995, 44\% dos projetos que tramitaram nesta casa legislativa passaram pela CCJ, enquanto o resto foi dividido em seis outras comissões.

A proposta demorou cinco anos para ser apreciada pela CCJ, algo que só ocorreu depois que Magalhães passou a presidir a comissão em 2005. Como presidente da comissão, pôde tentar realizar duas tarefas típicas de um empreendedor: mobilizar o apoio de outros atores políticos fortes em torno de sua proposta (sem sucesso) e indicar o relator que daria o parecer para sua proposta (com sucesso).

Para a primeira tarefa, Magalhães convenceu alguns aliados próximos a defenderem seu projeto no plenário ${ }^{186}$. Neste mesmo sentido, o líder do governo no Senado, Aloizio Mercadante (PT-SP), apelou para a convocação de audiências públicas com governadores e prefeitos para evitar que o projeto fosse aprovado. Tarefa arriscada: embora os governadores brasileiros tenham tido seu status de "barões da federação" (Abrucio 1988) bastante reduzido, sendo atores que pouco influenciam decisões importantes das bancadas estaduais na Câmara dos Deputados (Arretche 2007; Cheibub,

\footnotetext{
${ }^{186}$ Doze deputados, de 2000 a 2005, defenderam algum tipo de proposta de Orçamento Impositivo no plenário. Seis deles eram do partido de Magalhães e cinco mencionaram a proposta do senador, pedindo sua imediata votação. À exceção de um parlamentar, todos os outros pertenciam a partidos de oposição ao governo. Pode-se aferir que a proposta de Magalhães encontrou mais ressonância entre políticos de seu círculo mais próximo, com pouco sucesso em angariar apoio de um grupo político diversificado e capaz de fazer o projeto passar em plenário contra a vontade do Executivo. Ver discursos dos deputados Confúcio Moura (5/12/2003), Luiz Carreira (22/1/2004), Corauci Sobrinho (22/1/2004), Antônio Carlos Magalhães Neto (22/1/2004), Cláudio Cajado (2/3/2004), Walter Pinheiro (28/12/2004), Alceu Colares (17/2/2005), Costa Ferreira (15/6/2005), Ivan Ranzolin (15/6/2005), Agnaldo Muniz (15/6/2005) e Lincoln Portela (15/6/2005) em www.camara.gov.br.
} 
Figueiredo e Limongi 2009), o apoio dessas figuras certamente não prejudicaria Magalhães. A definição do pedido das audiências só foi obtida depois de divergências entre Mercadante e Antônio Carlos Magalhães (PFL-BA) ${ }^{187}$. Magalhães não teve sorte: um dos governadores enviou relatório não apoiando explicitamente a proposta, e um dos prefeitos chamou-a de "inoportuna".

Quanto à indicação do relator para o projeto na CCJ, trata-se de um grande trunfo para Magalhães e seu projeto. Os poderes dos relatores de comissões são consideráveis no sistema político brasileiro. Segundo Santos e Almeida (2005, p. 699700), "ao relator cabe proferir parecer sobre a matéria, sugerindo sua rejeição ou aprovação, incorporando ou não, a seu critério, eventuais emendas apresentadas pelos demais membros da comissão. A escolha dos relatores é atribuição exclusiva do presidente da comissão, não havendo restrição alguma quanto a quais membros da comissão e por quantas vezes podem ser designados para relatar projetos".

César Borges, do mesmo partido e estado de Magalhães, foi o relator da PEC 22/2000. Borges já foi descrito pela mídia como "afilhado", "apadrinhado"189 e "aliado" 190 de Magalhães - enfim, alguém "orientado"191 pelo senador. Sua atuação como relator impediu que o governo, através de Aloizio Mercadante, desfigurasse a PEC do Orçamento Impositivo. Mercadante propôs quatro emendas ao projeto ${ }^{192}$, uma das quais pode ser considerada uma tentativa de "killer amendment". Uma emenda a certo projeto se qualifica como killer se sua adição provoca o fracasso deste projeto que, anteriormente, tinha apoio da maioria, de acordo com Finocchiaro e Jenkins (2008, p. 263).

A quarta emenda de Mercandante propõe a extinção da Comissão mista de Orçamento e, portanto, a descentralização do processo orçamentário nas duas casas do

\footnotetext{
187 "PT evita votação do Orçamento impositivo", Valor Econômico, 24/03/2005, p. A8

188 “ACM morre aos 79 anos em São Paulo”, Diário de Natal, 21/7/2007, p. 9.

189 “ACM decide só sair da Bahia após decisão sobre a Ford”, Folha de S. Paulo, 08/07/1999.

190 “Adversários e aliados se despedem de ACM", www.g1.globo.com, 21/07/2007, acessado em 10/7/2009.

191 "PT evita votação do Orçamento impositivo", Valor Econômico, 24/03/2005, p. A8.

192 A primeira emenda de Mercadante propunha que os gastos previstos no orçamento não devem ser especificados no nível municipal, mas sim no estadual, pois seria um "trabalho legiferante hercúleo e irracional por se tratar de 5.563 cidades". A segunda emenda propõe que alterações ao processo orçamentário sugeridas pela PEC 22/2000 sejam adotadas obrigatoriamente por estados e municípios. A terceira emenda propõe que os prazos para o início do Orçamento Impositivo e outros itens da PEC 22/2000 sejam definidos por lei complementar, pois "são "de grande magnitude e envergadura". Esta emenda exemplifica muito bem o embate entre coalizão e oposição em torno da proposta, pois trata-se de tentar anular a espécie de sunset provision às avessas incluída pela senador conservador, já citada anteriormente. Foi a única das quatro emendas apresentadas por Mercadante que o relator César Borges rejeitou no mérito, com a justificativa de que o teor da emenda “já está contemplada” na PEC 22/2000.
} 
Congresso Nacional. Ao justificar esta emenda, Mercadante afirma: “... se a intenção que leva à apresentação da PEC 22/2000 é a afirmação do Congresso Nacional para dispor sobre matérias orçamentárias, caberia adotar um modelo similar ao norteamericano $^{193}$ ), no qual as Casas deliberam, separadamente, com plenas atribuições e prerrogativas, sobre questões orçamentárias. Não se justificaria, nesse novo contexto, a manutenção da Comissão Mista de Orçamento". Esta é uma clara tentativa de killer amendment pois a Comissão Mista de Orçamento é uma típica power base congressual, distribuindo enormes recursos e poder para os parlamentares - e partidos - que a controlam. A extinção da CMO seria extremamente contestada pela coalizão, como vimos também no quinto capítulo .César Borges conseguiu driblar a estratégia de Mercadante, que era atrelar o fim da Comissão Mista de Orçamento ao Orçamento Impositivo para que os defensores da comissão derrubassem, simultaneamente, as duas propostas.

Esta emenda, junto com a primeira e a segunda também propostas por Mercadante, foi incluída para votação na Comissão de Constituição e Justiça em 18/5/2005, poucos meses após Magalhães assumir a presidência da CCJ. Foram aprovadas em 11/7/2006 com apoio de 16 dos 23 senadores que integravam a comissão ${ }^{194}$. Com anuência tácita da Mesa Diretora, que não criou dificuldades para o projeto de Magalhães seguir a plenário ${ }^{195}, 56$ de 81 senadores aprovaram a proposta na primeira votação em plenário, realizada no mesmo dia. Interessante notar que a emenda de Mercadante que propôs a extinção da Comissão Mista de Orçamento foi, naquele momento, votada separadamente do projeto e contou com a oposição do senador Gilberto Mestrinho, que presidiu esta comissão em 2003. No início de agosto de 2006, o projeto de Magalhães foi aprovado no plenário do Senado, em segunda votação, com 55 votos e seguiu para a Câmara dos Deputados.

\section{o fracasso da proposta de Magalhães na Câmara dos Deputados}

Assim que a PEC 22/2000 chegou à Câmara dos Deputados, Magalhães viu seu poder de persuasão enormemente reduzido. Mahoney e Thelen (2009, p. 12) notam que um

\footnotetext{
${ }^{193}$ Para uma análise de em que medida o Congresso norte-americano inspira organizações legislativas em outros países, ver os ensaios reunidos em Power e Rae (2006).

1949 de 18 do bloco PFL/PSDB; 4 de 14 do bloco governista do PT/PSB/PL/PPS; 2 de 12 do PMDB; 1 de 2 do PDT.

${ }^{195}$ Agradeço Simone Diniz por me chamar atenção para este ponto.
} 
ator político que se encontra em desvantagem em certa instituição (neste caso, Magalhães na Câmara dos Deputados) pode usar sua influencia e status em outra instituição (neste caso, o Senado Federal) para obter a mudança institucional desejada. O senador conservador não conseguiu determinar o rumo de seu projeto na Comissão de Constituição e Justiça (CCJ) da Câmara dos Deputados, ao contrário de como vimos que fez no Senado Federal.

A CCJ da Câmara dos Deputados é estratégica para todos os partidos, pois pode determinar o rumo de projetos de lei e emendas constitucionais, (Müller 2005, p. 373). Os partidos confiam os postos na CCJ aos parlamentares mais leais. Nas palavras de Müller (2005, p. 387), "há um padrão nítido na composição das comissões, a partir do qual os membros da direção nacional dos partidos são alocados. A CCJ é a comissão que agrega o maior número de atuantes em diretórios nacionais. As indicações para esta comissão, de acordo com cada partido, mostram o PT como o que mais investiu nesse critério, com quatro membros de sua direção nacional, sendo seguido pelo PFL e PMDB, ambos com três membros". Ribeiral (1998), citada por Ricci e Lemos (2004, p. 110), aponta que a CCJ da Câmara dos Deputados é extremamente ativa, pois exerce seu poder terminativo e, apesar da grande rotatividade de membros, favorece a especialização interna.

Considerando a centralidade da CCJ para os trabalhos legislativos na Câmara dos Deputados, não espanta que a coalizão governista nela tenha maioria e consiga manejar os trabalhos de modo a conseguir certos resultados, sobretudo através da indicação de relatores e/ou formação de maioria na comissão para conseguir derrubar pareceres de relatores de oposição - comuns, aliás, segundo Santos e Almeida (2005).

Vale relembrar que esses e outros mecanismos foram usados pela coalizão liderada pelo Executivo para evitar a aprovação de algumas propostas de Orçamento Impositivo tanto na Câmara dos Deputados quanto no Senado Federal. A coalizão não indicou relator para o projeto, assim impedindo sua votação pela comissão (projetos 218/2004; 205/2004; 195/2004; 385/2005; 46/2007; 96/2007; 281/2008; 321/2009); indicou um relator que propôs a rejeição da proposta pela comissão (projetos 87/2003, 4786/2005); indicou um relator que não apresentou relatório, assim impedindo a votação da proposta pela comissão (projeto 169/2003). No caso desses doze projetos, o poder do Executivo como líder da coalizão se exerceu discretamente.

Processo semelhante se deu com o projeto de Magalhães na Câmara dos Deputados. O deputado Paulo Maluf (PP-SP), apesar de pertencer à coalizão, deu 
parecer favorável ao projeto de Magalhães na CCJ em 12/4/2007 ${ }^{196}$. Este parecer foi devolvido a Maluf em duas ocasiões (15/5/2007 e 13/7/2007) por falta de quórum para votação na comissão. Além disso, a coalizão governista se mobilizou em 18/3/2008, através dos deputados Antonio Carlos Biscaia, Colbert Martins e José Genoíno, para pedir vistas do parecer e atrasar por uma semana sua votação na CCJ.

A decisão final sobre o projeto de Magalhães na Câmara dos Deputados foi tomada em abril de 2008. Os deputados Paulo Magalhães (PFL), Felipe Maia (PFL) e Silvinho Peccioli (PFL) assinam o mesmo voto em separado, favorável à proposta de Orçamento Impositivo. O deputado governista José Eduardo Cardozo, do PT, apresenta voto em separado ao parecer de Maluf contrário ao projeto de Magalhães.

Se para Cardozo o orçamento impositivo "subverte o planejamento da ação governamental futura e impossibilita ao Executivo o exercício de suas atribuições constitucionalmente estipuladas", para os oposicionistas a proposta "reforça o equilíbrio entre o Executivo e o Legislativo, amesquinhado pelo descaso do primeiro em relação ao orçamento aprovado". A oposição percebeu que não teria fôlego para aprovar o projeto e optou por retirá-lo da pauta da CCJ. Assim, a maioria governista liderada pelo Executivo agiu silenciosamente e forçou o abandono do projeto de Magalhães. Em julho de 2007, o entrepreneur que tanto brigou para ver sua proposta aprovada faleceu em São Paulo.

Como é possível medir o sucesso de Magalhães? É inegável que, apesar de sua proposta de Orçamento Impositivo não haver sido aprovada, o senador obteve relativo sucesso. Trata-se de um projeto legislativo bastante contrário aos interesses do ator político mais poderoso do sistema brasileiro, o Executivo. Conseguiu levar o projeto ao plenário do Senado e obteve parecer favorável do relator na Comissão de Constituição e Justiça tanto do Senado Federal (César Borges) quanto da Câmara dos Deputados (Paulo Maluf). É também indicador do relativo sucesso de Magalhães o fato de que seu projeto não foi rejeitado no próprio Senado, algo que aconteceu com $83 \%$ dos projetos senatoriais não-aprovados entre 1991 e 2003 (Ricci 2008, p. 251), por se tratar de uma casa legislativa bastante auto-reguladora ${ }^{197}$ (Ricci 2003, p. 723).

\footnotetext{
${ }^{196}$ Paulo Maluf, ex-prefeito de São Paulo, é um notório inimigo político do presidente Luiz Inácio Lula da Silva. (Ver, por exemplo, "Lula provoca Maluf ao falar do combate ao crime organizado", Diário de S. Paulo, 28/3/2003.) Portanto, sua caracterização como pertencente à coalizão governista, devido ao fato de o partido ao qual é filiado ter conseguido um ministério no início de 2007, deve ser tomada com uma pitada de sal. Além disso, Maluf criticou duramente, à época, o fato de o Executivo editar medidas provisórias que alteram parte do orçamento. Ver Comissão de Constituição e Justiça, 2007.

${ }^{197}$ Os 17\% restantes foram aprovados no Senado Federal e rejeitados na Câmara dos Deputados.
} 
Para finalizar a seção, é pertinente retomar três quesitos assinalados por Campbell (2004, p. 86) para que um entrepreneur tenha sucesso: i) a capacidade de encaixar a proposta inovadora no contexto institucional; ii) habilidade em mobilizar apoio político em torno da proposta; iii) a disponibilidade de recursos financeiros, administrativos etc. para que a proposta seja viável. (Por se tratar de uma mudança institucional e não de policy, o terceiro quesito pouco interessa.)

A habilidade de Magalhães em mobilizar apoio compensou, parcialmente, a absoluta falta de encaixe de sua proposta no contexto institucional brasileiro. Veremos, na seção a seguir, os enquadramentos discursivos (frames) utilizados pelo senador para defender o projeto de Orçamento Impositivo e como eles revelam os interesses de curto e longo prazo dos atores políticos envolvidos.

\section{4) Interesses, idéias e enquadramentos discursivos sobre instituições orçamentárias}

A relação entre interesses e idéias de atores políticos é essencial para entender dinâmicas de mudança e estabilidade institucional, como frisei na introdução teórica à tese. A análise de enquadramentos (frames) discursivos pode elucidar a complicada interação entre idéias e interesses ao revelar como interesses de longo prazo são mobilizados para defender idéias que satisfazem interesses de curto prazo, como a reeleição e acesso a postos institucionais.

No caso do Orçamento Impositivo, observaremos que parlamentares utilizam enquadramentos relacionados a interesses de longo prazo como estratégia retórica para obscurecer interesses de curto prazo, relacionados à reeleição (como a execução de emendas individuais ao orçamento e participação na Comissão Mista de Orçamento). Uma explicação possível para isso é que os interesses de longo prazo - por exemplo, em defesa do Legislativo como ator coletivo - parecem mais legítimos e menos egoístas do que outros. É importante frisar, também, que os enquadramentos dependem fortemente do contexto histórico no qual os atores estão inseridos. Podemos esperar que, em uma critical juncture iniciada por causa de um escândalo de corrupção, o enquadramento do tipo "corrupção" seja mais recorrente do que outros, por exemplo.

Idéias e interesses determinam o conteúdo de mudanças institucionais como a proposta por Magalhães. A análise agora trata de como o proponente de certa idéia bastante subversiva e contrária a poderosos atores políticos, neste caso - pode jogar retoricamente de modo a convencer mais atores a defendê-la. 
Meu argumento básico é que Magalhães defende o Orçamento Impositivo Intermediário porque esta idéia institucional é consoante tanto com dois de seus principais interesses como ator político: o interesse como plausível líder oposicionista a médio prazo e o interesse como importante líder parlamentar - basta lembrar que em 2000 Magalhães presidia o Senado. A idéia de orçamento impositivo explicita, em primeiro lugar, interesses de curto e médio prazo do senador. (Lembremos que sua proposta implementaria a nova instituição orçamentária apenas dois anos após a aprovação legislativa da idéia.) Isto significa que é muito plausível imaginar que Magalhães calculava, no futuro, ser líder da oposição ao novo governo. Ora, estar na oposição a um Executivo que tem a instituição Orçamento Autorizativo a usar significa perder poder de barganha e, conseqüentemente, emendas orçamentárias executadas, como argumentei acima. Portanto, o Orçamento Impositivo seria excelente para satisfazer este interesse "egoísta” de Magalhães como futuro líder de oposição ${ }^{198}$.

O segundo interesse de Magalhães consoante com a idéia de Orçamento Impositivo é de longo prazo e relacionado à sua importância como líder legislativo. Em 2000, quando propôs a PEC 22/2000, Magalhães era presidente do Senado. É razoável imaginar que o senador tinha expectativas de continuar a influenciar os trabalhos congressuais por algum tempo. Assim, ele se fortaleceria quanto mais importante fosse a instituição sobre a qual ele tem influência. Ora, com o Orçamento Impositivo o Legislativo se fortaleceria como ator coletivo.

Quais tipos de enquadramentos podemos esperar que Magalhães use? Os enquadramentos que explicitem seus interesses de longo prazo e escondam seus interesses de curto e médio prazo, aparentemente "egoístas". Isto poderia facilitar o apoio de outros atores políticos em torno da idéia do Orçamento Impositivo.

Este tipo de ação não é novidade. Adler (2002, p. 222) aponta a necessidade de usar enquadramentos para defender reformas institucionais internas ao Legislativo "de modo que os colegas do entrepreneur pensem que com as reformas virão vantagens para a representação e reeleição". Em debates sobre mudanças de sistemas eleitorais, afirma Elster (1995, p. 147-148), partidos pequenos defendem a representação proporcional por ser "mais democrática" e partidos grandes propõem o sistema majoritário uninominal

\footnotetext{
198 No entanto, conforme ressaltei acima, outros dois fatores também podem ter influenciado os atos de Magalhães: o mal-estar na coalizão governista entre 1999 e 2001 e uma possível estratégia para barganhar outros projetos.
} 
por "facilitar a governabilidade" - nenhum dos partidos admite que sob cada um dos sistemas suas chances eleitorais aumentam.

Outras instituições também são afetadas por essa estratégia retórica. A Ordem dos Advogados Brasileiros, por exemplo, esconde-se, quando criticada, através do pilar de haver sido "um movimento popular a favor da democratização do país", obscurecendo o fato de ser um grupo de interesse com claras funções corporativistas (Taylor 2008, p. 119-120). Um exemplo mais próximo ao de meu caso é o de instituições orçamentárias na União Européia. Enderlein e Lindner (2006, p. 198-200) observam que uma das propostas defendidas pelo Parlamento Europeu para a reforma do processo orçamentário sugere eliminar a distinção entre gastos obrigatórios e nãoobrigatórios. Esta idéia pode ser defendida com um enquadramento discursivo que enfatiza interesses de curto prazo (por exemplo, maior eficiência econômica e menores oportunidades para conflitos políticos) ou combatida com enquadramentos que enfatizam interesses de longo prazo (por exemplo, a relação de poder entre o Conselho Europeu e o Parlamento Europeu). No caso do Orçamento Impositivo no Brasil, quais enquadramentos podem ser usados para mobilizar ou desincentivar o apoio de atores políticos? Observemos a tabela 6.5. 
Tabela 6.5: Frames Presumidos dos Atores Políticos em relação ao Orçamento Impositivo

\begin{tabular}{|c|c|c|c|c|}
\hline & Coalizão & Oposição & Executivo & Magalhães \\
\hline $\begin{array}{l}\text { 1) Com OI, "governo não poderá ter eficiência na } \\
\text { condução da macroeconomia; pois ficará de mãos atadas } \\
\text { para tratar de urgentes crises econômicas" - Frame } \\
\text { "Eficiência" }\end{array}$ & $\begin{array}{l}\text { Uso } \\
\text { provável }\end{array}$ & - & $\begin{array}{l}\text { Uso } \\
\text { provável }\end{array}$ & Usou \\
\hline $\begin{array}{l}\text { 2) Com OI, "governo deixará de ter uma importante } \\
\text { moeda de negociação com o Legislativo, pois é esse o } \\
\text { papel de contingenciar (ou simplesmente não gastar) } \\
\text { certas emendas orçamentárias" - Frame "Barganha } \\
\text { Política" }\end{array}$ & $\begin{array}{l}\text { Uso } \\
\text { provável }\end{array}$ & - & $\begin{array}{l}\text { Uso } \\
\text { provável }\end{array}$ & Usou \\
\hline $\begin{array}{l}\text { 3) Com OI, "“"governo será obrigado a fazer gastos ruins } \\
\text { e/ou inúteis incluídos pelos parlamentares" - Frame } \\
\text { "Representação do Executivo" }\end{array}$ & - & - & $\begin{array}{l}\text { Uso } \\
\text { provável }\end{array}$ & Não usou \\
\hline $\begin{array}{l}\text { 4) Com OI, "Legislativo finalmente conseguirá fazer o } \\
\text { que Constituição manda e compartilhará comando da } \\
\text { macroeconomia com o poder Executivo" - Frame } \\
\text { "Legislativo como ator coletivo" }\end{array}$ & $\begin{array}{l}\text { Uso } \\
\text { provável }\end{array}$ & $\begin{array}{l}\text { Uso } \\
\text { provável }\end{array}$ & - & Usou \\
\hline $\begin{array}{l}\text { 5) Com OI, "governo não mais poderá contingenciar as } \\
\text { emendas orçamentárias incluídas pelo Legislativo, corpo } \\
\text { político que representa as vontades da sociedade - ao } \\
\text { contrário do burocrático Executivo }- \text { Frame } \\
\text { "Representação do Legislativo" }\end{array}$ & $\begin{array}{l}\text { Uso } \\
\text { provável }\end{array}$ & $\begin{array}{l}\text { Uso } \\
\text { provável }\end{array}$ & - & Usou \\
\hline $\begin{array}{l}\text { 6) Com OI, "governo deixará de chantagear e fazer a } \\
\text { barganha corrupta com parlamentares onde só executa } \\
\text { emendas caso os parlamentares votam de acordo com os } \\
\text { interesses do Executivo" - Frame "Barganha Corrupta" }\end{array}$ & - & $\begin{array}{l}\text { Uso } \\
\text { provável }\end{array}$ & - & Não usou \\
\hline $\begin{array}{l}\text { 7) Com OI, "o sistema político brasileiro terá instituições } \\
\text { orçamentárias iguais às de países bem-sucedidos, como } \\
\text { os Estados Unidos" - Frame "Difusão" }\end{array}$ & $\begin{array}{l}\text { Uso } \\
\text { provável }\end{array}$ & $\begin{array}{l}\text { Uso } \\
\text { provável }\end{array}$ & - & Usou \\
\hline $\begin{array}{l}\text { 8) Com OI, "processo orçamentário brasileiro será } \\
\text { menos corrupto, pois haverá menores brechas durante o } \\
\text { processo para atores políticos ou econômicos mal- } \\
\text { intencionados" - Frame "Corrupção" }\end{array}$ & $\begin{array}{l}\text { Uso } \\
\text { provável }\end{array}$ & $\begin{array}{l}\text { Uso } \\
\text { provável }\end{array}$ & $\begin{array}{l}\text { Uso } \\
\text { provável }\end{array}$ & Não usou \\
\hline
\end{tabular}

Na justificativa formal para a PEC 22/2000, Magalhães utilizou três enquadramentos que podem ser associados tanto à coalizão quanto a oposição (frames 4,5 e 7), a depender do relacionamento prático dos parlamentares com o Executivo, e dois enquadramentos (frames 1 e 2) que poderia ser utilizado tanto por membros da coalizão quanto do Executivo.

Há uma clara predominância, no entanto, dos enquadramentos que frisam o papel de "representação" dos parlamentares e do Legislativo como "ator coletivo". De catorze enquadramentos utilizados por Magalhães na justificativa da proposta, oito tratam desses dois assuntos. Outros dois enquadramentos tratam da "eficiência" do Executivo; dois de "corrupção", um de "barganha" e um utiliza o argumento de 
“diffusion”, segundo o qual instituições de países estrangeiros devem inspirar reformas institucionais no Brasil ${ }^{199}$.

Ao escrever que sua proposta tem o objetivo de inserir "princípios e regras que coíbam a ditadura do Executivo em matéria orçamentária"; que não devemos remeter "para os burocratas do Executivo a arbitragem de quem pode e de quem não pode ser contemplado com as dotações orçamentárias, em flagrante usurpação das prerrogativas que são próprias do Legislativo"; que tempo demais é gasto pelos líderes partidários em "ntermináveis negociações para conciliar os justos e legítimos pleitos das bancadas com assento no Congresso Nacional"; que não pode haver a "usurpação das legítimas atribuições de um dos poderes da República, o que é intolerável em um regime democrático"; que "o que se tem em mira é restabelecer o equilíbrio entre os poderes"; que o orçamento "deve refletir as aspirações da sociedade em vez de espelhar apenas as deliberações tomadas nos refrigerados gabinetes da Esplanada dos Ministérios"; que a prerrogativa de o Executivo decidir o timing dos gastos transformou em "arbitrário o poder discricionário"; que o Congresso Nacional "sempre agiu e agirá em benefício do povo brasileiro" e esta situação toda tem causado muito desgaste "à imagem do Legislativo perante a sociedade", Magalhães claramente age como alguém que visa beneficiar o Legislativo como ator coletivo. Isto, como já disse, é bastante consoante com seus interesses de longo prazo.

O frame "Corrupção" foi utilizado por Magalhães duas vezes, ao afirmar que “com o objetivo de cicatrizar a grande chaga da corrupção orçamentária nossa proposta determina que uma vez iniciada a execução de um projeto este deve ter garantido o aporte de recursos nos orçamentos seguintes, até a sua conclusão", pois o orçamento, por se tratar de uma peça legislativa previsível, pode se tornar "susceptível a influências externas, acopladas a interesses que não condizem com a indispensável lisura e com o bem-estar da coletividade". Este frame também tem a ver com interesses de longo prazo de Magalhães, pois o Legislativo como um todo se beneficiaria de uma imagem dissociada da corrupção.

\footnotetext{
${ }^{199}$ Neste sentido, Magalhães afirmou: “A comparação de nossa proposta com a experiência internacional é sempre pertinente. $\mathrm{O}$ caso dos Estados Unidos se aproxima bastante de nossa realidade, uma vez que lá o sistema de governo é presidencialista - como o nosso - e, igualmente, uma federação. Nos EUA, sempre que o Executivo não pode executar uma programação ou, por razões outras, pretende executá-la posteriormente, o presidente é obrigado a submeter essa decisão à aprovação de uma das casas do Congresso. Portanto, trata-se de instrumento perfeitamente ajustado aos princípios democráticos e ao sistema presidencialista de governo".
} 
Quanto ao frame "Barganha Política", Magalhães o usa discretamente, escrevendo que "a programação orçamentária muitas vezes tem se prestado como instrumento de barganha política". O senador é mais explícito ao usar o frame "Eficiência" duas vezes, mostrando uma discreta aproximação retórica a certos interesses do Executivo. Afirmou que "é até compreensível e aceitável que as autoridades econômicas primem pelo uso do poder discricionário para ajustar a programação do orçamento aos meios disponíveis para executá-la” e, mais longamente, que "não poderíamos deixar de reconhecer que uma série de fatores impedem o Executivo de implementar esta ou aquela programação orçamentária. Um ciclo de conjuntura adversa que frustre as expectativas de arrecadação; a inadimplência de uma entidade, ou ente federado, na prestação de contas; a falta de apresentação de projetos consistentes para aplicação dos recursos. São situações às quais podemos agregar casos extremados - como calamidades públicas de grandes proporções; declarações de estado de guerra; resposta a agressão armada estrangeira - que podem obrigar o Executivo a dar outra orientação a determinada programação da lei orçamentária. Nessas hipóteses, a proposta prevê que o Executivo enviará ao Congresso Nacional solicitação de cancelamento ou de contingenciamento total ou parcial de dotações orçamentárias. Na solicitação devem ficar explícitas as justificativas de natureza técnica, econômicofinanceira, operacional ou jurídica da impossibilidade de execução da programação".

O que o uso desses enquadramentos por Magalhães pode nos dizer sobre sua estratégia política? Caso o senador tivesse usado mais frames ligados à sua posição na oposição ao Executivo, poderíamos aferir que a proposição do Orçamento Impositivo por ele tenha sido estratégica para barganhar em torno de outros projetos ou outras vantagens. Não parece ter sido este o caso, pois Magalhães frisou enormemente os frames ligados ao Legislativo como ator coletivo. Assim, justifica-se que outro ganho com a análise dos enquadramentos se refere a um esclarecimento sobre intenções e estratégia dos atores políticos.

Deve ter ficado claro, portanto, que parlamentares freqüentemente utilizam enquadramentos relacionados a interesses de longo prazo como estratégia retórica para obscurecer interesses de curto prazo. Estudar frames é importante, para distinguir esses dois tipos de interesses e como eles se relacionam a idéias concretas.

Os argumentos expostos neste capítulo têm clara ligação com os dois capítulos anteriores. O quarto capítulo avaliou como escândalos de corrupção e as critical junctures derivadas parcialmente deles ajudaram a alterar diversos aspectos do 
emendamento orçamentário no Brasil. O quinto capítulo mostrou como o entrepreneur de oposição Ricardo Barros conseguiu, em 2006, ser extremamente bem-sucedido na descentralização de aspectos da Comissão Mista de Orçamento. Este capítulo expôs como mesmo uma idéia com forte apoio dentro e fora do parlamento (o Orçamento Impositivo), sustentada por um entrepreneur de grande prestígio e detentor de recursos políticos consideráveis (Antônio Carlos Magalhães), não conseguiu superar o controle da agenda exercido pela coalizão governista contra esta proposta - que, afinal, feriria diretamente o controle da execução orçamentária pela coalizão. A narrativa explicitada aqui, portanto, mostra como os mesmos mecanismos mobilizados para explicar casos de mudança institucional nos outros capítulos - a saber, o controle da agenda legislativa dentro ou fora de critical junctures e a ação de entrepreneurs - podem ser utilizados para tratar de estabilidade institucional. A literatura institucionalista costuma tratar com argumentos teóricos diferentes os processos de estabilidade institucional (geralmente associados à path dependence) e os de mudanças institucionais. Este capítulo mostra que tal divisão pode não ser tão necessária. 


\section{Capítulo 7}

\section{Considerações Finais}

Em 1990, o deputado federal João Alves (PPR), Relator-Geral do processo orçamentário daquele ano, tinha liberdade para propor emendas orçamentárias com novos projetos. Aproveitava-se de um vasto vazio institucional resultante da falta de uma resolução congressual que regulasse a tramitação do orçamento; afinal, a Constituição Federal de 1988 tratava apenas das regras básicas. Alves propôs um parecer preliminar sobre a proposta orçamentária do Executivo com o conteúdo que queria, sem trechos obrigatórios nem análise detalhada da conjuntura econômica. $\mathrm{O}$ mais famoso "anão do orçamento" tinha também a prerrogativa de avaliar as emendas individuais propostas por seus colegas parlamentares, sem fixar um limite de valor máximo e sem autorizar emendas propostas coletivamente. Sozinho, Alves podia, por fim, reestimar à vontade a receita prevista pelo Executivo para o ano seguinte.

Dezessete anos depois, este cenário tornou-se impossível. O Relator-Geral de 2007, José Pimentel (PT), não pôde propor "emendas de relator" que colocassem novos projetos no orçamento. Seguiu os 161 artigos das 38 páginas da Resolução 1/2006 do Congresso Nacional, que dispõe sobre a tramitação do projeto orçamentário no Legislativo. Pimentel propôs um parecer preliminar de 75 páginas, com duas partes ${ }^{200}$, extremamente detalhado. Parlamentares propuseram emendas individuais e emendas coletivas através das comissões da Câmara dos Deputados e Senado Federal e das bancadas estaduais. Definiu-se um valor máximo para cada parlamentar emendar individualmente o orçamento, após negociações com líderes partidários. A Resolução 1/2006 fixou em 25 o número de emendas individuais a serem propostas por cada parlamentar. Pimentel teve que trabalhar com Francisco Dornelles, o Relator da Receita, para definir a reestimativa em relação à proposta do Executivo.

\footnotetext{
${ }^{200}$ A parte geral (I) avaliou as metas fiscais em função dos resultados primário e nominal implícitos no projeto; a programação orçamentária comparada com a execução do exercício anterior e o autorizado pela Lei Orçamentária em vigor; as despesas divididas por áreas temáticas; a compatibilização com o projeto de lei do plano plurianual, com a lei de diretrizes orçamentárias e a Lei Complementar $\mathrm{n}^{\circ} 101$, de 2000. A parte especial (II) definiu asregras, parâmetros e critérios que nortearam os trabalhos das relatorias; o limite financeiro para apresentação e atendimento das emendas individuais; orientações específicas referentes à apresentação e apreciação de emendas, inclusive de relator, e cancelamentos em dotações constantes do projeto; reavaliação das despesas obrigatórias e da reserva de contingência; critérios adotados na distribuição da reserva de recursos; competências temáticas, programação passível de ser objeto de emenda individual.
} 
Este trabalho avaliou como se deram todas as mudanças ocorridas do primeiro parágrafo para o segundo, além da estabilidade do Orçamento Autorizativo, que permite ao Executivo gastar o orçamento aprovado pelo Legislativo com extrema autonomia. $\mathrm{O}$ desenvolvimento institucional do processo orçamentário brasileiro de 1987 a 2008 não foi desprezível. Esta tese mobilizou uma literatura teórica que está na interesecção entre os institucionalismos histórico e de escolha racional, com especial ênfase em como os interesses e idéias dos atores interagem.

\section{(1) Contribuições substantivas}

O primeiro capítulo da tese definiu o framework teórico a partir do qual foram desenvolvidos os argumentos da tese. A interação entre interesses, idéias e enquadramentos discursivos permite explicar como e por que certas instituições orçamentárias brasileiras foram escolhidas, desde 1987, em vez de outras. O capítulo argumenta que os interesses dos parlamentares a respeito das instituições orçamentárias é definido, em grande parte, por como essas instituições funcionam na prática. Mostro que a estratégia de execução orçamentária utilizada pelo Executivo Brasileiro no período pós-1988 é fundamental para explicar por que parlamentares da coalizão devem, em tese, defender limites ao emendamento, a organização centralizada da Comissão Mista de Orçamento e o Orçamento Autorizativo. Os parlamentares da oposição, por sua vez, devem defender emendamento ilimitado, a descentralização da comissão orçamentária e o Orçamento Impositivo.

O capítulo dois definiu três critical junctures relacionadas a instituições orçamentárias brasileiras: a Assembléia Constituinte de 1987-1988, o período pós-CPI de 1994-1995 e a época de 2005-2006, com forte ênfase nessas últimas duas. Ainda que Mahoney e Thelen (2009) frisem a importância de processos graduais de mudança institucional, é inegável que critical junctures permitem que circulem de modo bastante livre as idéias institucionais que informam esses processos. Portanto, defini-las e analisá-las com rigor é fundamental. O mesmo capítulo também mostrou como são formadas as preferências dos atores políticos brasileiros sobre instituições orçamentárias, através do método da narrativa analítica.

A escolha de instituições orçamentárias pela Assembléia Nacional Constituinte de 1987-1988 é o tema do capítulo três. Trata-se de uma critical juncture na qual os interesses legislativos tratados acima (reeleição, acesso a postos institucionais, 
pertencimento à coalizão/oposição, Legislativo como ator coletivo) têm peso diferente em relação aos outros períodos analisados. Ao inserir as escolhas de instituições orçamentárias na lógica do processo constituinte, entende-se por que certas instituições da ditadura militar foram mantidas (por exemplo, a Comissão Mista de Orçamento) e outras foram ressuscitadas, parcialmente, do regime democrático de 1946-1964 (por exemplo, a prerrogativa de parlamentares emendarem o orçamento).

O capítulo quatro aborda as escolhas pós-constituinte a respeito das instituições que regulam o emendamento orçamentário e o capítulo cinco trata da organização da Comissão Mista de Orçamento. As critical junctures de 1994-1995 e 2005-2006 são analisadas detalhadamente em ambos os capítulos, identificando todas as idéias em circulação e quais interesses - revelados ou não por frames - informam essas idéias. Os dois casos são associados a processos de mudança institucional analisados por Mahoney e Thelen (2009) - layering para as emendas, conversion para a comissão orçamentária.

A estabilidade do Orçamento Autorizativo no Brasil é analisado no capítulo seis, que pode ser visto como um caso complementar aos demais, pois trata do que Cappocia e Kelemen (2007) chamam de "near miss": uma quase mudança institucional. Os enquadramentos discursivos utilizados pelo entrepreneur Antônio Carlos Magalhães, principal defensor do fim do Orçamento Autorizativo, revelam quais interesses legislativos estiveram presentes na decisão de manter essa instituição. O capítulo expôs como mesmo uma idéia com forte apoio dentro e fora do parlamento (o Orçamento Impositivo), sustentada por um entrepreneur de grande prestígio, conseguiu superar o controle da agenda exercido pela coalizão governista contra esta proposta - que, afinal, feriria diretamente o controle da execução orçamentária pela coalizão. Esta narrativa mostra como os mesmos mecanismos mobilizados para explicar casos de mudança institucional nos outros capítulos - a saber, o controle da agenda legislativa dentro ou fora de critical junctures e a ação de entrepreneurs - podem ser utilizados para tratar de estabilidade institucional. A literatura institucionalista costuma tratar com argumentos teóricos diferentes os processos de estabilidade institucional e os de mudanças institucionais. Argumento que tal divisão pode não ser tão necessária.

\section{(2) Contribuições teóricas}

É relevante destacar três pontos teóricos com os quais este trabalho pode ter avançado para o estudo de instituições. O primeiro trata da relação entre interesses, idéias e 
instituições. Se o institucionalismo de escolha racional postula que atores concordarão com certa mudança institucional apenas se acreditam que esta melhorará seus resultados, o institucionalismo histórico lembra que crenças normativas (legitimidade, justiça etc.) também afetam escolhas institucionais (Hall 2009, p. 210-211). No caso deste trabalho, essas crenças normativas são mobilizadas nos enquadramentos discursivos (frames) utilizados por atores e entrepreneurs para legitimar idéias que podem parecer ligadas demais a seus interesses de curto prazo, mais "egoístas". Assim, a análise de enquadramentos discursivos permite perceber que interesses de longo prazo também são mobilizados por atores na defesa e ataque a escolhas institucionais.

Esta análise está bastante em linha com o que Hall (2009, p. 211-212) chama de "preferências multivariadas". Significa simplesmente que todo ator pode ter um conjunto multidimensional de preferências e interesses a respeito de certa instituição. Um dos diversos exemplos encontrados neste trabalho é a defesa de emendas individuais, que condiz tanto com o interesse de curto prazo do parlamentar em se reeleger quanto o interesse de longo prazo em fortalecer o Legislativo como ator coletivo, aquele que tem "legitimidade para emendar". Podemos esperar que este segundo interesse seja dito, enquanto sobre o primeiro silencia-se.

O segundo ponto teórico está relacionado ao fato de que nem sempre a posição institucional ocupada por um ator determina suas idéias, ao contrário do que defende a "teoria de interesses" da linha analítica de escolha racional (Blyth 2003). Se um ator defende uma idéia contrária a seus interesses de curto prazo, chamo isso de "preferência deslocada". Os capítulos quatro e cinco expuseram diversos exemplos referentes a escolhas de instituições orçamentárias no Brasil. Mas por que preferências se deslocam?

Há quatro explicações possíveis. A primeira é que a preferência pelas instituições X e Y, menos importantes, é guiada pela preferência pela instituição $\mathrm{Z}$, muito mais importante para certo ator. Vale lembrar, por exemplo, que uma comissão orçamentária centralizada é mais importante para a coalizão liderada pelo Executivo no Brasil do que o emendamento limitado, já que a coalizão controla a execução orçamentária. Esta explicação é bastante semelhante à análise de Tsebelis (1990) sobre "jogos ocultos". Meu argumento frisa as circunstâncias nas quais as "preferências deslocadas" tendem a prosperar: são facilitadas por critical junctures. Isto leva à segunda explicação. A preferência pela instituição X1 é fortemente mal-vista em certo momento, pois ela é associada à corrupção ou algum outro aspecto negativo. Para não 
parecer corrupto, ator muda sua preferência para a instituição X2, mesmo que esta não seja tão condizente com certos interesses de curto prazo.

A terceira explicação para que haja "preferências deslocadas" é que certo ator quer ser visto como entrepreneur em relação a certo conjunto de instituições, de modo a se tornar referência em uma área e talvez um dia ser ministro etc. (Afinal, o ex-membro da Comissão Mista de Orçamento, Paulo Bernardo, tornou-se ministro do Planejamento.) O melhor modo de ser entrepreneur é ter preferências suficientemente deslocadas para, sendo "democrata", atrair membros de outros partidos. E assim conseguir fazer suas preferências passarem e tomar crédito pela reforma institucional concretizada, como o deputado federal Ricardo Barros fez com a Resolução 1/2006. Por fim, a quarta explicação pode ser chamada de "argumento trustee"201 . O ator pode se informar que sua predileção pela instituição A (por exemplo, barreiras tarifárias) é altamente danosa para certo objetivo (por exemplo, crescimento econômico), ainda que seja muito boa para seus eleitores e/ou financiadores de campanha. Assim, o ator "lidera" seus eleitores de modo a fazê-los mudar de opinião - ou seja, atua como trustee em vez de delegate. Vimos, nos capítulos quatro, cinco e seis, uma mistura das três primeiras explicações para "preferências deslocadas".

Vale lembrar que a análise de critical junctures - no caso deste trabalho, associadas a escândalos de corrupção orçamentária - mostra como a circulação de idéias nelas é afetada, mas os resultados finais dependem de quem controla a agenda legislativa. Entrepreneurs que conseguem driblar o controle da agenda, como Ricardo Barros, podem ser bem-sucedidos, ao contrário de outros como Antônio Carlos Magalhães, que precisava de recursos hercúleos para enfrentar a coalizão na questão do Orçamento Impositivo.

O terceiro ponto teórico avançado nesta tese diz respeito à importância de estudar tanto mudanças institucionais quanto estabilidade institucional, utilizando o mesmo arsenal teórico. O quarto capítulo, sobre emendamento orçamentário, mostra que os escândalos de corrupção têm mais impacto quando os stakes são relativamente baixos. Os dois capítulos seguintes mostram que quando os stakes são mais altos para a

\footnotetext{
${ }^{201}$ Há uma antiga controvérsia sobre o estilo ideal de representação política: o representante deve se comportar como alguém em quem os representados depositam confiança, e chega às decisões com base em sua avaliação própria dos fatos, ou o representante deve agir como um delegado e desconsiderar sua própria opinião, favorecendo a de seus eleitores? O primeiro seria um trustee e o segundo um delegate, de acordo com Eulau et. al (1959).
} 
coalizão - como é o caso da comissão centralizada e do Orçamento Autorizativo -, o controle da agenda é mais importate.

O ponto que quero frisar é que os mecanismos que causam mudanças institucionais são os mesmos responsáveis por estabilidade institucional. Nas palavras de Hall (2009, p. 217), “a persistência de instituições não é uma questão de aderência cega, mas o resultado contingente do exercício de poder". A estabilidade, como o capítulo seis mostrou, é bastante disputada politicamente. Perceber isso é fugir do pior tipo de análise de processos path dependent, que parecem esquecer que ao mesmo tempo em que certos interesses políticos sustentam uma instituição, pode haver outros interesses fortemente contrários a ela. Este raciocínio explica como as defesas de idéias como "Orçamento Impositivo", "fim das emendas individuais" e "fim da Comissão Mista de Orçamento" fracassaram: há interesses fortissimos, mais ou menos ocultos, que sustentam essas idéias mesmo em critical junctures influentes.

\section{(3) Dois desafios teóricos}

É importante considerar dois desafios teóricos para futuras pesquisas, ambos ligados à contribuição de Mahoney e Thelen (2009) sobre mudanças institucionais. O primeiro ponto trata de usar análise contrafactual para avaliar como o processo de mudança institucional poderia ter sido um em vez de outro, algo que Capoccia e Kelemen (2007, p. 358) sugerem. Os escândalos de corrupção e a ação de um entrepreneur foram fundamentais para definir o desenho de instituições de emendamento orçamentário no Brasil, como mostrou o quarto capítulo. Como exercício contrafactual, podemos imaginar três cenários distintos. A variação se dá no impacto da CPI de 1993-1994, já que a adoção ou não das idéias colocadas na agenda por esta CPI foram cruciais para o desenvolvimento posterior das instituições.

O primeiro cenário seria a CPI não influenciar nem a agenda de idéias da critical juncture nem os resultados finais. Ou seja, haver manutenção simples do status quo. Neste caso, o processo institucional seria caracterizado como conversion, pois haveria o uso de emendas individuais por outros atores que não aqueles que foram investigados pela CPI (neste caso, os "anões do orçamento"). Outra possibilidade seria a CPI influenciar a agenda temática da critical juncture de modo parcial, vendo algumas das idéias adotadas e outras não pelo grupo politico que controlou a agenda da critical juncture. Foi o que ocorreu, resultando em layering institucional - ou seja, regras novas 
convivendo com regras antigas. Por fim, outro cenário possível seria a adoção integral de idéias da CPI - como o fim das emendas individuais - por outro grupo politico em controle da agenda da critical juncture (a oposição, neste caso). Ocorreria, assim, o que Mahoney e Thelen (2009) chamam de displacement: extinção de regras antigas e a introdução de novas instituições.

O último ponto teórico que merece atenção no futuro é a relação entre obediência (compliance) institucional e informalidade. Instituições informais nunca estiveram à frente das preocupações de analistas institucionalistas tanto da linha da escolha racional quanto da linha institucionalista histórica. No entanto, a recente contribuição de Mahoney e Thelen (2009) parece conciliar os avanços mais importantes das duas linhas analíticas ao mesmo tempo em que consegue incorporar a compliance de atores à análise institucional, algo fortemente ligado ao estudo de instituições informais.

Um dos argumentos básicos dos autores é que mudanças institucionais freqüentemente ocorrem quando problemas de interpretação de regras, imposição (enforcement) e obediência (compliance) ocorrem e abrem espaço para que atores implementem regras existentes de novas maneiras. Certos tipos de instituições estão associadas a certos agentes de mudança (change-agents). São razoavelmente originais, sobretudo em relação ao institucionalismo de escolha racional, ao ressaltar que instituições não são "auto-impositivas": alguns atores podem seguir as regras X, Y, Z da instituição enquanto outros seguem as regras X e Z. Ou seja, a compliance de cada ator em relação às regras é um fator que deve ser levado em conta para pensar o funcionamento institucional na prática, bem como os caminhos possíveis de mudança institucional.

Espera-se que mudanças incrementais ocorram nos vazios (gaps) entre a existência da regra, a interpretação da regra e a imposição da regra. Trata-se, para Mahoney e Thelen (2009, p. 17-18), de um espaço analítico que outras definições de instituições ignoram, mas, na prática, é exatamente onde instituições são contestadas e redefinidas. Segundo Thelen (2009, p. 491), os vazios institucionais podem ter quatro origens.

A primeira trata de limites cognitivos dos atores que desenharam as instituições. É impossível, afinal, controlar completamente os usos feitos das instituições que eles desenharam. No caso do processo orçamentário brasileiro, um dos principais framers dessas instituições na Assembléia Nacional Constituinte, José Serra, reclamou 
fortemente do uso da instituição "erros e omissões" pelos membros da Comissão Mista de Orçamento entre 1988 e 1993. Algo que foi pensado como uma correção técnica à estimativa de receita feita pelo Executivo tornou-se instrumento para justificar receitas que financiavam emendas parlamentares corruptas.

A segunda origem dos vazios institucionais são acordos políticos. Regras são freqüentemente ambíguas por natureza, como consequiência dos acordos que permitiram sua escolha em primeiro lugar. A terceira origem é que os perdedores à época da gênese institucional podem comandar a instituição mais tarde e dar a ela outros fins e usos. Isto ocorreu com a Comissão Mista de Orçamento após 1995, quando a coalizão liderada pelo Executivo passou a controlá-la com cuidado. Por fim, vazios institucionais podem ocorrer com mudanças contextuais que abrem muito espaço para reinterpretações que moldam a instituição de modo contrário ao que seus framers tencionavam. O fim da hiperinflação brasileira em 1994 levou à enorme redefinição sobre a importância do processo orçamentário para o sistema político.

Se Mahoney e Thelen (2009) inserem elegantemente a informalidade dentro do debate teórico institucionalista, é fundamental também debater os efeitos e diferentes tipos de "desobediência institucional" (non-compliance). Para isto, há a contribuição analítica de Helmke e Levitsky (2006, p. 5). Instituições informais são, segundo esses autores, regras socialmente compartilhadas, normalmente não-escritas, que são criadas, comunicadas e reforçadas através de mecanismos institucionais extra-oficiais.

Dois fatores são considerados para definir o tipo de instituição informal: o grau de convergência entre instituições formais e informais e a eficácia de instituições formais. Em relação ao grau de convergência, pergunta-se: seguir regras informais leva a resultados diferentes do que seguir instituições formais? Se sim, instituições são divergentes; se não, instituições são convergentes. Em relação à eficácia das instituições formais, são consideradas eficazes caso os atores políticos temam algum tipo de sanção/punição caso as violem e ineficazes caso não haja sanção para atores que desobedeçam regras formais. Ou seja, são ineficazes se a non-compliance institucional, para lembrar os termos de Mahoney e Thelen (2009), não é punida.

Instituições informais complementares podem ser de dois tipos. Um deles simplesmente preenche espaços deixados por instituições formais, resolvendo contingências imprevistas pelo desenho formal. Outro tipo ajuda atores políticos a perseguir seus objetivos de modo mais eficaz dentro de certo desenho institucional formal (Helmke e Levitsky 2006, p. 13). O cartel corrupto que ocupou a Comissão 
Mista de Orçamento no Brasil de 1989 a 1993 operava sob instituições informais complementares. Ao definirem um rodízio informal de relatores, geralmente associados a interesses corruptos, e conferir grande poder ao relator-geral do orçamento - para citar dois exemplos-, parlamentares preenchiam lacunas deixadas tanto pela Constituição Federal quanto pelo Regimento Interno e perseguiam objetivos escusos de modo eficaz. Instituições informais complementares, portanto, operam em um ambiente no qual as regras formais são eficazes e convergentes às informais.

No entanto, é possível afirmar também que havia instituições informais acomodativas no mesmo período. Trata-se, de acordo com Helmke e Levitsky (2006, p. 15) da existência de incentivos para que atores se comportem de modo a alterar o efeito substantivo de instituições informais, mas sem violá-las diretamente. Ou seja, contrariam o espírito, mas não a gramática (letter) das regras formais. No período dos “anões”, isto ocorria porque tanto a Constituição Federal quanto o Regimento Interno e regras congressuais sobre o processo orçamentário não eram diretamente violados pela informalidade corrupta.

Há um claro ganho da tipologia de Helmke e Levitsky (2006), adaptada a partir de Lauth (2000), para o entendimento dos efeitos de instituições informais. Conforme eles mesmos afirmam, a maior parte da literatura trata as instituições informais ou como inteiramente funcionais, resolvendo problemas de interação social e coordenação (e.g., Knight 1992), ou como completamente disfuncionais (clientelismo, corrupção etc.). Assim, a tipologia ajuda a capturar relações entre instituições formais e informais que são mais complexas do que essa dicotomia faria entender.

\section{(4) Caminhos futuros para o estudo de instituições}

Vale especular, por fim, sobre a utilidade heurística do conceito de "preferências deslocadas" proposto neste trabalho. Argumento que este conceito pode ser usado para explicar decisões paradoxais - ou seja, que contrariam interesses de curto prazo - tanto de atores políticos brasileiros quanto de qualquer outro sistema político.

Este trabalho mostrou, nos capítulos quatro e cinco, 22 decisões relativas ao emendamento orçamentário e à organização da Comissão Mista de Orçamento - onze na critical juncture de 1994-1995, onze na critical juncture de 2005-2006. Dez dessas decisões foram paradoxais: oito das catorze sobre o emendamento, duas das oito sobre a organização da CMO. O fato de haver menos decisões paradoxais sobre a organização 
da comissão orçamentária sustenta o argumento de que a coalizão governista se preocupava mais em manter os poderes do relator-geral da comissão do que em manter limites ao emendamento - afinal, desde que o presidente controle a execução orçamentária, as conseqüências indesejadas do emendamento ilimitado podem ser muito bem calibradas.

Há também exemplos internacionais de decisões institucionais paradoxais. Um deles é a escolha de sistema eleitoral na Alemanha, que mudou do sistema majoritário de 1949 para o sistema misto (representação proporcional e majoritária) em 1953. Bawn (1993, p. 987) argumenta que a estratégia racional para o SPD (Social Democratic Party) em 1953 seria manter o sistema majoritário - afinal, era o segundo maior partido, junto com o CDU/CSU (Christian Democratic Party/Christian Social Union) e concentrava razoável poder de barganha.

No entanto, o SPD optou pelo sistema misto por calcular que, assim, o partido CDU/CSU teria menos chance de liderar coalizões no futuro. Trata-se, portanto, de uma escolha paradoxal. O "deslocamento de preferências" dos social-democratas foi um cálculo estratégico, consoante com o argumento de Tsebelis (1990). Esta tese mostra, no entanto, que nem todas as preferências se deslocam por motivos estratégicos.

Outra possibilidade de deslocamento de preferências vem de crises econômicas, sociais e políticas. Como já afirmei acima, a preferência pela instituição X1 pode ser fortemente mal-vista em certo momento, pois ela é associada à corrupção ou algum outro aspecto negativo. Então o ator muda sua preferência para a instituição X2, mesmo que esta não seja tão condizente com certos interesses dele. Nesse sentido, Blustein (2001, p. 175-205) relata sobre como Kim Dae Jung (“DJ”) presidente recém-eleito da Coréia do Sul no fim de 1997, tinha, historicamente, preferências econômicas "populistas", anti-liberais. No entanto, devido à crise econômica que acometia o país quando de sua eleição, Dae Jung se viu na posição de aceitar um pacote de condicionalidades do Fundo Monetário Internacional bastante contrário às suas preferências iniciais. Crises econômicas não nos faltarão. Talvez o conceito de "preferências deslocadas" proposto nesta tese seja uma ferramenta metodológica a auxiliar sua compreensão. 


\section{Anexo I}

Circulação de Idéias sobre Aspectos de Emendamento Orçamentário, 1988-2008

Caso 1: Circulação de Idéias sobre o Número de Emendas Individuais, 1988-2008

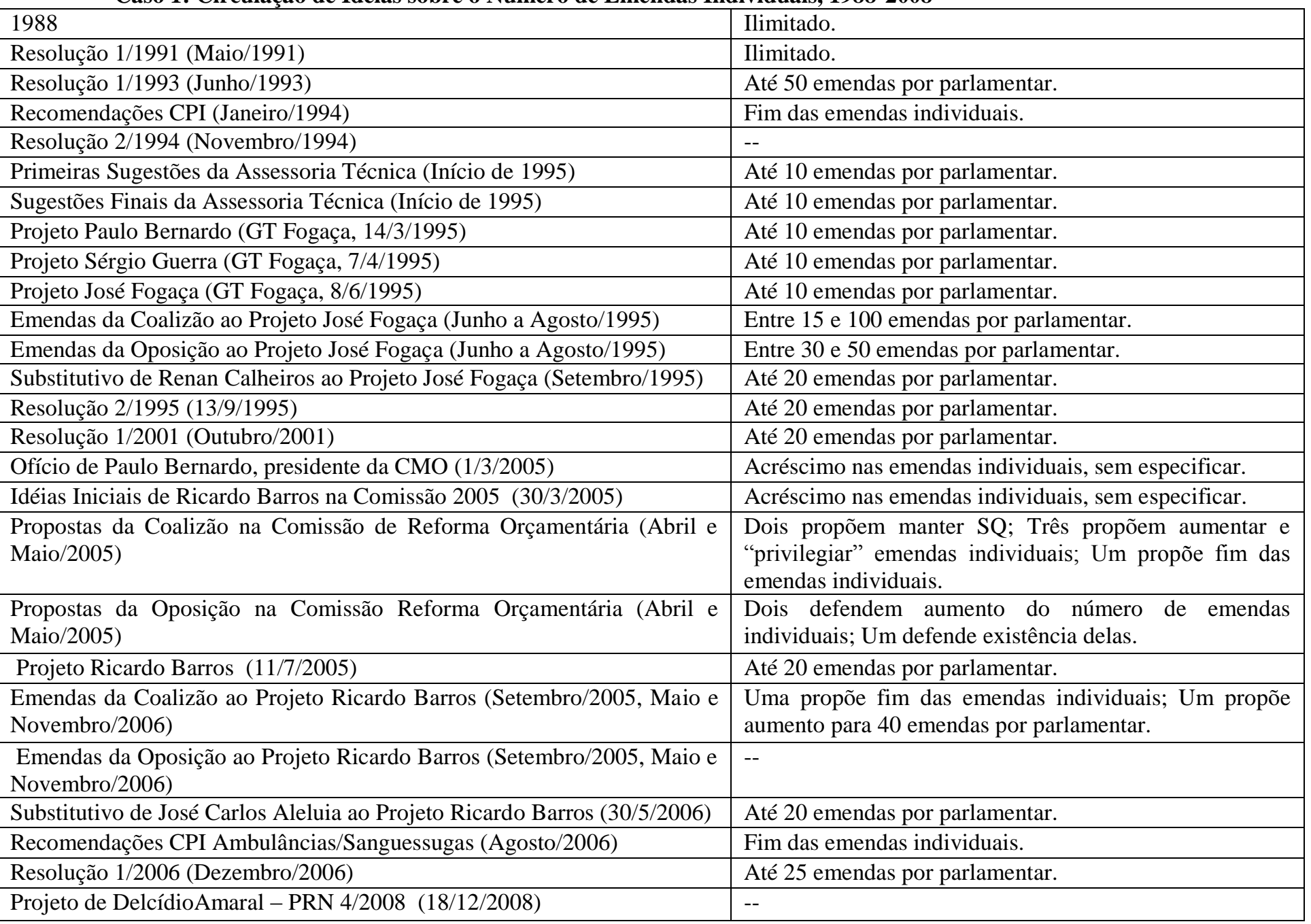


Caso 2: Circulação de Idéias sobre a Natureza de Emendas Individuais, 1988-2008

\begin{tabular}{|c|c|}
\hline 1988 & $\begin{array}{l}\text { 1) compatível com PPA e LDO } \\
\text { 2) indicar recursos necessários, admitidos apenas os que anulem } \\
\text { despesas (excluídas as com transferências para municípios etc.; } \\
\text { serviço da dívida; gastos com pessoal) } \\
\text { 3) indicar recursos necessários, podendo vir da correção de "erros ou } \\
\text { omissões" }\end{array}$ \\
\hline Resolução 1/1991 (Maio/1991) & $\begin{array}{l}\text { Pontos } 1,2 \text { e } 3 \\
\text { 4) não podem ser constituídas de várias partes que devam ser objeto } \\
\text { de emendas distintas }\end{array}$ \\
\hline Resolução 1/1993 (Junho/1993) & -- \\
\hline Recomendações CPI (Janeiro/1994) & 1) Fim das emendas individuais; 2) Extinção das subvenções sociais \\
\hline Resolução 2/1994 (Novembro/1994) & -- \\
\hline Primeiras Sugestões da Assessoria Técnica (Início de 1995) & -- \\
\hline Sugestões Finais da Assessoria Técnica (Início de 1995) & -- \\
\hline Projeto Paulo Bernardo (GT Fogaça, 14/3/1995) & Pontos 1,2 e 3 \\
\hline Projeto Sérgio Guerra (GT Fogaça, 7/4/1995) & Pontos 1,2 e 3 \\
\hline Projeto José Fogaça (GT Fogaça, 8/6/1995) & $\begin{array}{l}\text { Pontos } 1,2,3 \text { e } 4 \\
\text { 5) podem indicar "erros e omissões" também nas estimativas de } \\
\text { receita, na discussão do parecer preliminar }\end{array}$ \\
\hline $\begin{array}{l}\text { Emendas da Coalizão ao Projeto José Fogaça (Junho a } \\
\text { Agosto/1995) }\end{array}$ & -- \\
\hline $\begin{array}{l}\text { Emendas da Oposição ao Projeto José Fogaça (Junho a } \\
\text { Agosto/1995) }\end{array}$ & -- \\
\hline $\begin{array}{l}\text { Substitutivo de Renan Calheiros ao Projeto José Fogaça } \\
\text { (Setembro/1995) }\end{array}$ & Pontos $1,2,3,4$ e 5 \\
\hline Resolução 2/1995 (13/9/1995) & $\begin{array}{l}\text { Pontos } 1,2,3,4 \text { e } 5 \\
6 \text { ) emendas podem usar valores acrescentados por reestimativa da } \\
\text { receita }\end{array}$ \\
\hline
\end{tabular}




\begin{tabular}{|c|c|}
\hline Resolucão 1/2001 (Outubro/2001) & $\begin{array}{l}\text { Pontos } 1,2,3,4,5 \text { e } 6 \\
\text { 7) cria Comitê de Admissibilidade de Emendas }\end{array}$ \\
\hline Ofício de Paulo Bernardo, presidente da CMO (1/3/2005) & -- \\
\hline $\begin{array}{l}\text { Idéias Iniciais de Ricardo Barros na Comissão } 2005 \\
(30 / 3 / 2005)\end{array}$ & -- \\
\hline $\begin{array}{l}\text { Propostas da Coalizão na Comissão de Reforma Orçamentária } \\
\text { (Abril e Maio/2005) }\end{array}$ & -- \\
\hline $\begin{array}{l}\text { Propostas da Oposição na Comissão Reforma Orçamentária } \\
\text { (Abril e Maio/2005) }\end{array}$ & $\begin{array}{l}\text { 1) emendas devem ser consistentes do ponto de vista } \\
\text { macroeconômico; 2) fim da emenda individual "guarda-chuva" }\end{array}$ \\
\hline Projeto Ricardo Barros (11/7/2005) & $\begin{array}{l}\text { Pontos } 1,2,3,4,5,6 \text { e } 7 \\
\text { 8) emendas só podem dar recursos a entidades privadas sob certas } \\
\text { condições: respeitando LDO; apenas para programação especificada } \\
\text { no parecer preliminar; estipular metas que entidade deve cumprir, } \\
\text { sendo essas compatíveis com valor da emenda; identifiquem } \\
\text { entidade beneficiada. } \\
\text { 9) emendas, em seu conjunto, devem resultar em montante suficiente } \\
\text { para que obra - ou etapa do cronograma da execução - seja } \\
\text { completada }\end{array}$ \\
\hline $\begin{array}{lccrcc}\text { Emendas da Coalizão } & \text { ao } & \text { Projeto } & \text { Ricardo } & \text { Barros } \\
(\text { Setembro/2005, Maio e Novembro/2006) } & & \end{array}$ & -- \\
\hline $\begin{array}{lcccc}\text { Emendas da } & \text { Oposição ao Projeto } & \text { Ricardo } & \text { Barros } \\
\text { (Setembro/2005, Maio e Novembro/2006) } & & \end{array}$ & -- \\
\hline $\begin{array}{l}\text { Substitutivo de José Carlos Aleluia ao Projeto Ricardo Barros } \\
(30 / 5 / 2006)\end{array}$ & $\begin{array}{l}\text { Pontos } 1,2,3,4,5,6,7,8 \text { e } 9 \\
8 \text {-a) emenda para entidade privada deve identificar a entidade } \\
\text { beneficiada, seu endereço e o nome dos responsáveis pela direção } \\
\text { 10) parecer preliminar definirá programação passível de ser objeto } \\
\text { de emendas, assim como os elementos que devem justificar cada } \\
\text { emenda }\end{array}$ \\
\hline $\begin{array}{l}\text { Recomendações } \\
\text { (Agosto/2006) }\end{array}$ & $\begin{array}{l}\text { * Fim das emendas individuais } \\
\text { 10) parecer preliminar definirá programação passível de ser objeto } \\
\text { de emendas e de transferências voluntárias } \\
\text { 11) exame obrigatório da adequação dos valores propostos pelas } \\
\text { emendas individuais, tendo presente os custos do empreendimento e } \\
\text { as metas pretendidas, evitando janelas orçamentárias ou } \\
\text { superdimensionamento da dotação; } \\
\text { 12) proíbe investimentos em entidades privadas; } \\
\text { 13) pró́be nepotismo em transferência de recursos para entidades } \\
\text { privadas }\end{array}$ \\
\hline
\end{tabular}




\begin{tabular}{|l|l|}
\hline Resolução 1/2006 (Dezembro/2006) & $\begin{array}{l}\text { Pontos 1, 2, 3, 4, 5, 6, 7, 8, 8-A, 11 } \\
\text { - divide emendas como "remanejamento", “apropriação" e } \\
\text { "cancelamento" } \\
\text { - Remanejamento: só serão admitidas as que cancelarem dotações. } \\
\text { - Apropriação: utiliza "Reserva de Recursos" e outros definidos no } \\
\text { parecer preliminar. } \\
\text { - Cancelamento: propõe redução de dotações no projeto. }\end{array}$ \\
\hline Projeto de DelcídioAmaral - PRN 4/2008 (18/12/2008) & $\begin{array}{l}\text { Mantém SQ. Comitê de Admissibilidade de Emendas permanece, } \\
\text { mas com menos poderes }\end{array}$ \\
& \\
\hline
\end{tabular}


Caso 3: Circulação de Idéias sobre os Atores que podem propor Emendas Coletivas, 1988-2008

\begin{tabular}{|c|c|}
\hline 1988 & -- \\
\hline Resolução 1/1991 (Maio/1991) & -- \\
\hline Resolução 1/1993 (Junho/1993) & $\begin{array}{l}\text { 1) comissões permanentes } \mathrm{SF} \text { e } \mathrm{CD} \text {, sobre matérias pertinentes } \\
\text { regimentalmente, com ata da reunião em que foram deliberadas: } \\
\text { até } 3 \text { emendas por comissão; } \\
\text { 2) partidos políticos com representação no } \mathrm{CN} \text {, assinadas pela } \\
\text { maioria absoluta da bancada: no mínimo } 1 \text { emenda, no máximo } \\
10 \text { emendas; } \\
\text { 3) bancadas estaduais, no mínimo } 1 / 3 \text { da bancada com } 5 \\
\text { parlamentares assinando: cada parlamentar pode encabeçar até } 3 \\
\text { emendas. }\end{array}$ \\
\hline Recomendações CPI (Janeiro/1994) & $\begin{array}{l}\text { Serão permitidas apenas emendas de comissão, bancada, e } \\
\text { partidos, fixando valores com critérios de proporcionalidade }\end{array}$ \\
\hline Resolução 2/1994 (Novembro/1994) & -- \\
\hline Primeiras Sugestões da Assessoria Técnica (Início de 1995) & $\begin{array}{l}\text { 1) comissões: até } 5 \text { emendas por comissão; } \\
\text { 2) partidos políticos: } 1 \text { emenda a cada } 5 \text { parlamentares; } \\
\text { 3) bancadas estaduais: } 10 \text { emendas por bancada, deliberadas por } \\
\text { 2/3 da bancada; } \\
\text { 4) bancadas regionais: até } 5 \text { emendas por região, deliberadas } \\
\text { pela maioria da bancada, sendo que cada estado ou DF deverá } \\
\text { estar representado por no mínimo } 20 \% \text { da bancada. }\end{array}$ \\
\hline Sugestões Finais da Assessoria Técnica (Início de 1995) & $\begin{array}{l}\text { 1) comissões: até } 5 \text { emendas por comissão; } \\
\text { 2) partidos políticos: } 1 \text { emenda por cada grupo de } 5 \\
\text { parlamentares; } \\
\text { 3) bancadas estaduais: } 10 \text { emendas por bancada, deliberadas pela } \\
\text { maioria da bancada. }\end{array}$ \\
\hline Projeto Paulo Bernardo (GT Fogaça, 14/3/1995) & Igual acima. \\
\hline Projeto Sérgio Guerra (GT Fogaça, 7/4/1995) & $\begin{array}{l}\text { 1) comissões: até } 5 \text { emendas por comissão; } \\
\text { 2) bancadas estaduais: } 10 \text { emendas por bancada, deliberadas por } \\
\text { 3/4 da bancada; } \\
\text { 3) bancadas regionais: até } 5 \text { emendas por bancada. }\end{array}$ \\
\hline $\begin{array}{l}\text { Emendas da Coalizão ao Projeto José Fogaça (Junho a } \\
\text { Agosto/1995) }\end{array}$ & -- \\
\hline $\begin{array}{l}\text { Emendas da Oposição ao Projeto José Fogaça (Junho a } \\
\text { Agosto/1995) }\end{array}$ & -- \\
\hline $\begin{array}{lllllll}\begin{array}{l}\text { Substitutivo de } \\
(\text { Setembro/1995) }\end{array} & \text { Renan Calheiros ao Projeto José Fogaça } \\
\end{array}$ & Igual ao projeto José Fogaça. \\
\hline Resolução 2/1995 (13/9/1995) & Igual ao projeto José Fogaça. \\
\hline Resolução 1/2001 (Outubro/2001) & $\begin{array}{l}\text { 1) comissões: até } 5 \text { emendas por comissão; } \\
\text { 2) bancadas estaduais: aprovadas por } 2 / 3 \text { dos deputados e } 2 / 3 \text { dos } \\
\text { senadores, no mínimo } 15 \text { emendas, no máximo } 20 \text {; } \\
\text { 3) bancadas regionais: até } 2 \text { emendas por região, deliberadas } \\
\text { pela maioria da bancada, sendo que cada estado ou DF deverá } \\
\text { estar representado por no mínimo } 20 \% \text { da bancada. }\end{array}$ \\
\hline Ofício de Paulo Bernardo, presidente da CMO (1/3/2005) & $\begin{array}{l}\text { 1) Redução no limite de emendas coletivas a serem apresentadas; } \\
\text { 2) Fim das emendas coletivas de bancada e regionais, }\end{array}$ \\
\hline Idéias Iniciais de Ricardo Barros na Comissão 2005 (30/3/2005) & $\begin{array}{l}\text { Soluções: 1) Redução do } \mathrm{n}^{\circ} \text { de emendas coletivas e aumento do } \\
\mathrm{n}^{\circ} \text { de emendas individuais. 2) } \mathrm{O} \mathrm{n}^{\circ} \text { de emendas da bancada deve } \\
\text { ser inferior ao } \mathrm{n}^{\circ} \text { de parlamentares da bancada; } 3 \text { ) Exigência de } \\
\text { critérios mais rígidos para a aprovação de emendas de bancada: } \\
\text { localização geográfica específica, repetição da emenda nos } \\
\text { exercícios subseqüentes até a conclusão de seu objeto; 4) }\end{array}$ \\
\hline
\end{tabular}


Propostas da Coalizão na Comissão de Reforma Orçamentária (Abril e Maio/2005)

Propostas da Oposição na Comissão Reforma Orçamentária (Abril e Maio/2005)

Projeto Ricardo Barros (11/7/2005) eliminação das emendas de Comissão; 5) emendas de Comissão atendidas somente pelo Relator-Geral; 6) emendas de Comissão atendidas somente pelos relatores setoriais; audiência dos relatores setoriais em todas as comissões que apresentarem emendas."

Três querem limite para emendas de bancada; Um é contra limite para emendas de bancada; Um quer limites para emendas de comissão; Um quer limite para emendas coletivas em geral

R. Barros:manter ou aumentar emendas de comissão; C. Martins/R. Barros: reduzir emendas de bancada; R. Dimas: contra redução de emendas de bancada; J. Leão: contra limite ao número de emendas de bancada; C. Martins: acabar com emendas de comissão e emendas regionais; R. Dimas: manter SQ de número de emendas coletivas

1) Comissões: a) para comissões com competência sobre uma única subárea temática, duas emendas são permitidas (1 de apropriação, 1 de remanejamento); b) para comissões com competência sobre mais de uma subárea temática, 6 emendas são permitidas (3 apropriacao, 3 remanejamento); c) As mesas diretoras do SF e da $\mathrm{CD}$ poderão apresentar 4 emendas de apropriação e 4 de remanejamento ; 2)Bancadas estaduais: até 12 emendas (9 apropriação, 3 de remanejamento), relativas a matérias de interesses de cada estado ou DF, aprovadas por $2 / 3$ dos deputados e $2 / 3$ dos senadores da respectiva unidade da federação.

Emendas da Coalizão ao Projeto Ricardo Barros (Setembro/2005, Maio e Novembro/2006)

Emendas da Oposição ao Projeto Ricardo Barros (Setembro/2005, Maio e Novembro/2006)

Substitutivo de José Carlos Aleluia ao Projeto Ricardo Barros $(30 / 5 / 2006)$

Recomendações CPI Ambulâncias/Sanguessugas (Agosto/2006)

Resolução 1/2006 (Dezembro/2006)

Um parlamentar propõe: Poderao ser apresentadas no mínimo 18 e no máxio 20 emendas de apropriacao, além de 3 de remanejamento, sendo que: as bancadas estaduais com mais de 11 parlamentares poderao apresentar, além do mínimo de 18 emendas, uma emenda de apropriacao para cada glupo completo de de 10 parlamentares da bancada que exceder a 11 parlamentares

Uma parlamentar propôs: 4 emendas de comissao (2 de apropriacao e 2 de remanejamento) para comissões com competencia em mais de uma subárea temática

1) comissões: a) até 4 emendas (2 apropriação, 2 remanejamento) pelas comissões cuja competência estiver restrita a uma única subárea temática, observados os quantitativos constantes do anexo desta resolução; b) até 8 emendas (4 apropriação, 4 remanejamento) para aquelas cuja competência abranja mais de uma subárea temática

*nada sobre emendas de mesas diretoras

2) Bancadas estaduais: mínimo 15, máximo 20 emendas de apropriação, além de 3 de remanejamento; 5 emendas para bancadas estaduais do $\mathrm{CN}$; bancadas estaduais com mais de 11 parlamentares poderao apresentar, além do mínimo de 15 emendas, uma emenda de apropriação para cada grupo completo de 10 parlamentares da bancada que exceder a 11 parlamentares; nas bancadas estaduais com mais de 18 parlamentares, caberá à representação do SF a iniciativa da apresentação de 3 emendas de apropriação daquela que trata o caput.

"Fortalecimento das emendas coletivas"

Art. 44. As emendas de Comissão: I - até 4 (quatro) emendas, sendo 2 (duas) de apropriação e 2 (duas) de remanejamento, para as comissões cuja competência esteja restrita a uma única subárea temática, conforme definido no $\S 1^{\circ}$ do art. 26 desta Resolução, e observados os quantitativos constantes do Anexo a esta Resolução;II - até 8 (oito) emendas, sendo 4 (quatro) de apropriação e 4 (quatro) de remanejamento, para aquelas cuja competência abranja mais de uma subárea temática, observados 
os quantitativos constantes do Anexo a esta Resolução; As Mesas Diretoras do Senado Federal e da Câmara dos Deputados poderão apresentar emendas, sendo até 4 (quatro) de apropriação e até 4 (quatro) de remanejamento.

- Art. 47. As emendas de Bancada Estadual deverão: I - ser apresentadas juntamente com a ata da reunião que decidiu por sua apresentação, aprovada por 3/4 (três quartos) dos Deputados e 2/3 (dois terços) dos Senadores da respectiva Unidade da Federação;Poderão ser apresentadas no mínimo 15 (quinze) e no máximo 20 (vinte) emendas de apropriação, além de 3 (três) emendas de remanejamento, sendo que: I - as Bancadas Estaduais com mais de 11 (onze) parlamentares poderão apresentar, além do mínimo de 15 (quinze) emendas, uma emenda de apropriação para cada grupo completo de 10 (dez) parlamentares da bancada que exceder a 11 (onze) parlamentares; II - nas Bancadas Estaduais integradas por mais de 18 (dezoito) parlamentares, caberá à representação do Senado Federal a iniciativa da apresentação de 3 (três) emendas de apropriação dentre aquelas de que trata o caput.

Simplificação da regra de apresentação das emendas de comissão - extinção da correlação com as áreas e subáreas temáticas e fixação de 4 emendas de apropriação e 4 de remanejamento para todas as comissões. A regra atual estabelecia correlação entre a competência regimental das comissões permanentes da Camara e Senado com os órgãos da administração pública federal. A intenção original foi a de evitar que diversas comissões apresentassem emenda para a mesma programação. Todavia, a norma criou limitações e conflitos com a dinâmica das atribuições regimentais das comissões e que estão previstas nos Regimentos Internos de ambas as Casas. Portanto, sugerimos que a competência de emendamento das comissões se atenha apenas às suas atribuições regimentais, como era a prática desde a Resolução 2/1995. Também sugerimos tornar fixo e equitativo o número de emendas de comissão, qual seja, 4 emendas de apropriação e 4 emendas de remanejamento para todas as comissões. 
Caso 4: Circulação de Idéias sobre o Valor Destinado a Emendas Coletivas, 1988-2008

\begin{tabular}{|c|c|}
\hline 1988 & -- \\
\hline Resolução 1/1991 (Maio/1991) & -- \\
\hline Resolução 1/1993 (Junho/1993) & -- \\
\hline Recomendações CPI (Janeiro/1994) & $\begin{array}{l}\text { Serão permitidas apenas emendas de comissão, bancada, e } \\
\text { partidos, fixando valores com critérios de proporcionalidade (mas } \\
\text { não especificados esses critérios). }\end{array}$ \\
\hline Resolução 2/1994 (Novembro/1994) & -- \\
\hline Projeto Paulo Bernardo (GT Fogaça, 14/3/1995) & -- \\
\hline Projeto Sérgio Guerra (GT Fogaça, 7/4/1995) & -- \\
\hline Projeto José Fogaça (GT Fogaça, 8/6/1995) & -- \\
\hline $\begin{array}{l}\text { Emendas da Coalizão ao Projeto José Fogaça (Junho a } \\
\text { Agosto/1995) }\end{array}$ & -- \\
\hline Resolução 2/1995 (13/9/1995) & -- \\
\hline Resolução 1/2001 (Outubro/2001) & -- \\
\hline Ofício de Paulo Bernardo, presidente da CMO (1/3/2005) & Redução no limite de emendas coletivas. \\
\hline Idéias Iniciais de Ricardo Barros na Comissão 2005 (30/3/2005) & -- \\
\hline $\begin{array}{l}\text { Propostas da Coalizão na Comissão de Reforma Orçamentária } \\
\text { (Abril e Maio/2005) }\end{array}$ & $\begin{array}{l}\text { S. Miranda: aumento do valor de emendas de comissão; F. } \\
\text { Bezerra: limite de valor para emendas de bancada }\end{array}$ \\
\hline $\begin{array}{l}\text { Propostas da Oposição na Comissão Reforma Orçamentária } \\
\text { (Abril e Maio/2005) }\end{array}$ & $\begin{array}{l}\text { Pauderney Avelino: emendas de bancadas de estados mais pobres } \\
\text { devem ser de maior valor; R. Barros: redução do valor e número } \\
\text { de emendas de bancada estadual; R. Dimas: limite do valor de } \\
\text { emendas coletivas }\end{array}$ \\
\hline $\begin{array}{l}\text { Emendas da Coalizão ao Projeto Ricardo Barros (Setembro/2005, } \\
\text { Maio e Novembro/2006) }\end{array}$ & $\begin{array}{l}\text { L. Castro: recursos para emendas coletivas de apropriação serão } \\
\text { definidos pelo RG no PP }\end{array}$ \\
\hline $\begin{array}{lcccc}\begin{array}{l}\text { Emendas da Oposição ao Projeto } \\
\text { (Setembro/2005, Maio e Novembro/2006) }\end{array} & & \text { Barros } \\
\end{array}$ & -- \\
\hline $\begin{array}{l}\text { Substitutivo de José Carlos Aleluia ao Projeto Ricardo Barros } \\
(30 / 5 / 2006)\end{array}$ & Mantém projeto Ricardo Barros. \\
\hline Recomendações CPI Ambulâncias/Sanguessugas (Agosto/2006) & "Fortalecimento das emendas coletivas." \\
\hline Resolução 1/2006 (Dezembro/2006) & $\begin{array}{l}\text { Mantém projeto Ricardo Barros, exceto critérios para distribuir } \\
\text { recursos para emendas de bancada estadual a seguir: } 50 \% \text { com } \\
\text { base nos critérios estabelecidos para o FPE; } 40 \% \text { com base na } \\
\text { média histórica de atendimento das respectivas Bancadas }\end{array}$ \\
\hline
\end{tabular}




\begin{tabular}{|l|l|}
\hline & $\begin{array}{l}\text { Estaduais nos últimos 3 anos; 10\% com base na população } \\
\text { residente estimada pelo IBGE. }\end{array}$ \\
\hline Projeto de DelcídioAmaral - PRN 4/2008 (18/12/2008) & -- \\
\hline
\end{tabular}


Caso 5: Circulação de Idéias sobre a Natureza de Emendas Coletivas, 1988-2008

\begin{tabular}{|c|c|}
\hline 1988 & -- \\
\hline Resolução 1/1991 (Maio/1991) & -- \\
\hline Resolução 1/1993 (Junho/1993) & $\begin{array}{l}\text { 1) emendas de comissão serão sobre matérias } \\
\text { "pertinentes regimentalmente"; } \\
\text { 2) emendas de comissão serão acompanhadas da } \\
\text { ata da reunião em que foram deliberadas; } \\
\text { 3) emendas de bancada tratarao de projetos "de } \\
\text { interesse estadual" }\end{array}$ \\
\hline Resolução 2/1994 (Novembro/1994) & -- \\
\hline Primeiras Sugestões da Assessoria Técnica (Início de 1995) & $\begin{array}{l}\text { 4) emenda coletiva tem que trazer referência a pré- } \\
\text { projeto de viabilidade; } \\
\text { 5) emenda coletiva tem que indicar indicação de } \\
\text { fonte de financiamento e eventuais contrapartidas; } \\
\text { 6) emenda coletiva precisa vir com relatório de } \\
\text { impacto ambiental; } \\
\text { 7) emenda coletiva precisa conter relação de } \\
\text { custo/benefício sócio-econômico; } \\
\text { 8) emenda coletiva precisa trazer prazos de } \\
\text { execução, }\end{array}$ \\
\hline Sugestões Finais da Assessoria Técnica (Início de 1995) & -- \\
\hline Projeto Paulo Bernardo (GT Fogaça, 14/3/1995) & -- \\
\hline Projeto Sérgio Guerra (GT Fogaça, 7/4/1995) & -- \\
\hline Projeto José Fogaça (GT Fogaça, 8/6/1995) & $\begin{array}{l}\text { Pontos } 1,2,3,4,5,7 \text { e } 8 \\
\text { 9) emenda coletiva precisa informar sobre o estágio } \\
\text { de execução dos investimentos já realizados }\end{array}$ \\
\hline Emendas da Coalizão ao Projeto José Fogaça (Junho a Agosto/1995) & -- \\
\hline Emendas da Oposição ao Projeto José Fogaça (Junho a Agosto/1995) & -- \\
\hline Substitutivo de Renan Calheiros ao Projeto José Fogaça (Setembro/1995) & Mantém projeto José Fogaça. \\
\hline $\begin{array}{l}\text { Propostas da Coalizão na Comissão de Reforma Orçamentária (Abril e } \\
\text { Maio/2005) }\end{array}$ & $\begin{array}{l}\text { Dois dizem que emendas de bancada precisam ser } \\
\text { "estruturantes"; Dois são a favor de critérios mais } \\
\text { rígidos para aprovar emendas de bancada; Um } \\
\text { afirma que emendas de comissão precisam se ater } \\
\text { às "áreas temáticas determinadas regimentalmente" }\end{array}$ \\
\hline $\begin{array}{l}\text { Propostas da Oposição na Comissão Reforma Orçamentária (Abril e } \\
\text { Maio/2005) }\end{array}$ & $\begin{array}{l}\text { Um diz que emendas coletivas devem levar em } \\
\text { conta interesses nacionais, não estaduais; Um diz } \\
\text { que emendas de comissão devem respeitar áreas } \\
\text { temáticas }\end{array}$ \\
\hline Projeto Ricardo Barros (11/7/2005) & $\begin{array}{l}\text { Pontos } 1,2,3,5,7,8 \\
\text { 11) emendas de bancada estadual que tratam de } \\
\text { projetos deverão identificar de forma precisa o } \\
\text { objeto da ação pretendida, vedada a designação } \\
\text { genérica de ações que possam contemplar obras } \\
\text { distintas em sua execução; e atender, } \\
\text { alternativamente, a projetos de grande vulto, } \\
\text { conforme definidos no PPA; ou projetos }\end{array}$ \\
\hline
\end{tabular}




\begin{tabular}{|c|c|}
\hline & $\begin{array}{l}\text { estruturantes de interesse nacional ou estadual, nos } \\
\text { termos do parecer preliminar, especificando-se o } \\
\text { objeto do gasto e a localização do } \\
\text { empreendimento; } \\
\text { 12) as emendas de bancada, uma vez propostas e } \\
\text { iniciadas com recursos federais, deverão } \\
\text { necessariamente ser objeto de emendas coletivas } \\
\text { até a sua conclusão, desde que esses não constem } \\
\text { do projeto de lei encaminhado pelo Executivo; } \\
\text { 13) as emendas de bancada que tratam de } \\
\text { atividades e operações especiais devem restringir- } \\
\text { se às modalidades de aplicação } 30 \text { e } 90\end{array}$ \\
\hline $\begin{array}{l}\text { Emendas da Coalizão ao Projeto Ricardo Barros (Setembro/2005, Maio e } \\
\text { Novembro/2006) }\end{array}$ & $\begin{array}{l}\text { Um propõe que emendas de bancadas estaduais } \\
\text { possam tratar de projetos menos abrangentes. }\end{array}$ \\
\hline $\begin{array}{l}\text { Emendas da Oposição ao Projeto Ricardo Barros (Setembro/2005, Maio e } \\
\text { Novembro/2006) }\end{array}$ & -- \\
\hline Substitutivo de José Carlos Aleluia ao Projeto Ricardo Barros (30/5/2006) & $\begin{array}{l}\text { - Mantém proposta de R. Barros. } \\
\text { 11-B) emendas de bancada devem - identificar de } \\
\text { forma precisa o seu objetivo, vedada a designação } \\
\text { genérica de programação que possa contemplar } \\
\text { obras distintas ou possam resultar, na execução, em } \\
\text { transferências voluntárias, convênios ou similares } \\
\text { para mais de um ente federativo ou entidade } \\
\text { privada". }\end{array}$ \\
\hline Recomendações CPI Ambulâncias/Sanguessugas (Agosto/2006) & $\begin{array}{l}\text { "Tornar punível a falta de cumprimento das normas } \\
\text { relativas à formalização dos convênios, } \\
\text { especialmente em relação à definição do plano de } \\
\text { trabalho, especificação precisa do objeto e dos } \\
\text { custos associados" }\end{array}$ \\
\hline Resolução 1/2006 (Dezembro/2006) & 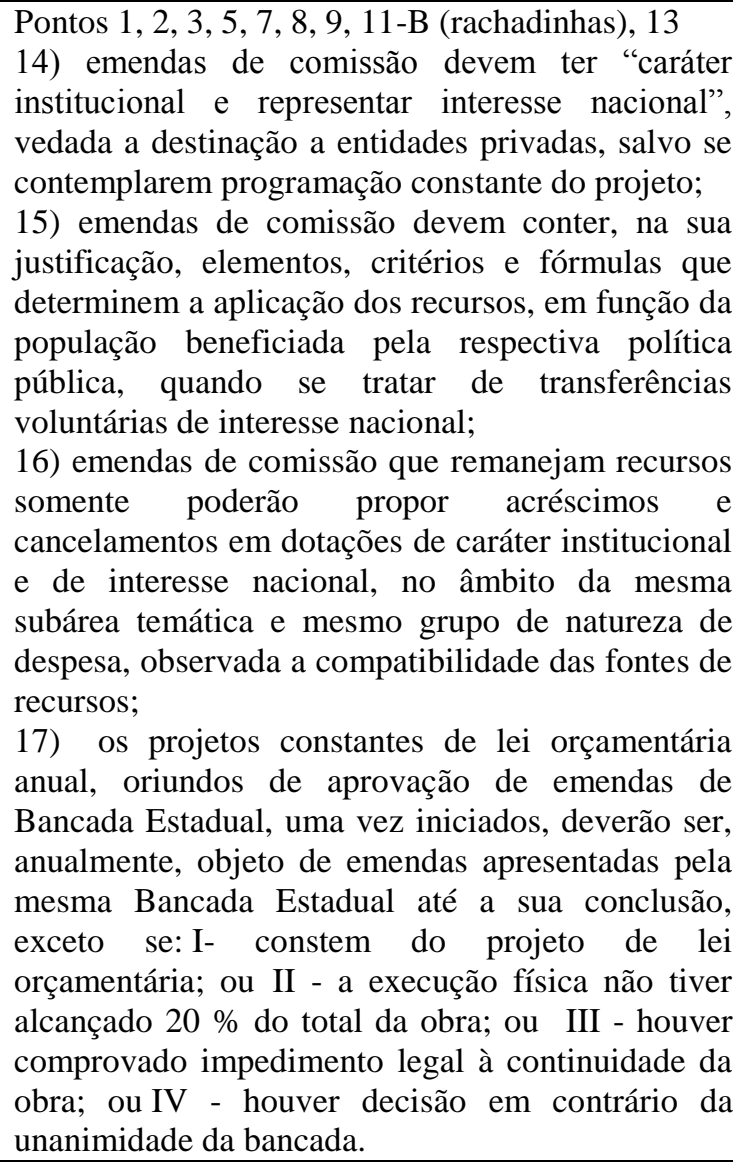 \\
\hline Projeto de DelcídioAmaral - PRN 4/2008 (18/12/2008) & $\begin{array}{l}\text { Diversas propostas contrárias à resolução } 1 / 2006: \\
\text { - "as emendas de bancada estadual devem poder }\end{array}$ \\
\hline
\end{tabular}


contemplar um conjunto articulado de obras em todo o estado, não podendo ficar limitadas a um município ou região metropolitana, desde que exista, previamente, programa específico"

- "Deve-se reconhecer a legitimidade da bancada buscar atender todo o estado com determinada política pública, ficando ao encargo do órgão executor, o Estado ou a União, a definição dos critérios de elegibilidade dos municípios onde serão realizadas as obras";

- "Propomos que a repetição obrigatória das emendas de bancada possa ser afastada com o quorum de 2/3 tanto dos deputados quando $2 / 3$ dos senadores do estado";

- "Simplificação da regra de apresentação das emendas de comissão - extinção da correlação com as áreas e subáreas temáticas" 


\section{Anexo II}

\section{Enquadramentos Discursivos (frames) sobre emendamento orçamentário}

1) Ator: Laura Carneiro (PFL, oposição)

Instância: Emenda ao projeto Ricardo Barros

Data: $13 / 9 / 2005$

Idéia: Limitar número de emendas de comissão

Interesse curto prazo: Pertencimento à oposição

Frame: Representação e Legitimidade Parlamentar: "As emendas de comissão aprovadas no processo de tramitacao da LOA tradicionalmente se coadunam com o interesse do Executivo nas áreas afetas às comissões permanentes. Entende-se que o Executivo tem a prerrogativa de alterar a peça orçamentária até o momento do envio da proposta para o CN. A partir desse instante, o governo deve se restringir a auxiliar os congressistas no sentido de informar e esclarecer pontos para o melhor andamento dos trabalhos de elaboracao da lei no ambito do Legislativo. Nesse sentido, ao reduzir o número de emendas destinadas às comissões, esta emenda visa a minimizar interferencia do Executivo no Parlamento durante a tramitacao do PLOA."

2) Ator: Primeiras sugestões da Assessoria Técnica

Instância: CPI 1993-1994

Data: Início de 1995

Idéia: Mais critérios para natureza de emendas coletivas

Interesse curto prazo: Não há.

Frame: Representação dos interessees do Estado: “O critério de apresentação de emendas de bancada não tem sido suficiente para que estas reflitam de fato projetos de interesse estadual. Neste sentido, a proposta tem a vantagem de obrigar a que haja uma reunião da bancada, com a conseqüente decisão conjunta das emendas prioritárias para a unidade de federação e também na nova modalidade por região."

\section{3) Ator: Recomendações CPI Ambulâncias/Sanguessugas}

Instância: CPI 2006

Data: Agosto de 2006

Idéia: Fim das emendas individuais

Interesse curto prazo: Não há.

Frame: Anti-Barganha: "Uma das primeiras soluções apontadas foi a extinção das emendas individuais. Preliminarmente, é preciso esclarecer que o esquema da Planan utilizou-se de transferências de recursos a municípios à conta de autorizações orçamentárias, tendo como origem emendas individuais, emendas coletivas ou mesmo a programação ministerial Não derivada de emendas. AsSim, problemas e desvios podem se valer Não apenas de dotações apropriadas pelas emendas individuais, mas de qualquer programação do orçamento. A extinção das emendas individuais transferirá o poder decisório para as emendas coletivas (bancadas e comissões) e para o Poder Executivo (Ministérios) quanto à especificação das autorizações genéricas; Adicionalmente, critica-se a emenda individual pelo seu caráter privatista do orçamento público. De fato, a emenda individual, da forma como hoje se apresenta, pode e é utilizada como instrumento de tráfico de influência e barganha política. A emenda representa uma parcela de poder do parlamentar na elaboração orçamentária. Incluída a programação, o princípio de impessoalidade, que deve reger o orçamento público, exige a neutralidade do parlamentar e do Poder Executivo na fase da execução. Com esse propósito, o Congresso Nacional incluiu, desde 2001, dispositivo nas LDOs prevendo que a execução da lei orçamentária e de seus créditos devem obedecer ao princípio da impessoalidade na Administração Pública, Não podendo ser utilizada para influir na apreciação de proposições legislativas em tramitação no Congresso Nacional. Outro dispositivo da LDO determina que a execução dos créditos orçamentários genéricos - aqueles que Não identificam o município beneficiado - fica condicionada à prévia publicação, pelo concedente, em órgão oficial de imprensa, dos critérios de distribuição. Sabemos que tais disposições Não têm sido eficazes, visto que os critérios, quando publicados, são excessivamente genéricos."

4) Ator: Romero Jucá (PSDB, coalizão)

Instância: Emenda ao Projeto José Fogaça

Data: Junho de 1995

Idéia: Ampliar para 15 emendas individuais por parlamentar

Interesse curto prazo: Reeleição 
Frame: Representação: “A presente emenda visa ampliar o número de emendas individuais a serem apresentadas ao PLOA, objetivando dar ao parlamentar um maior número de opções para atender às reivindicações de suas bases"

\section{5) Ator: Sugestões Finais Assessoria Técnica}

Instância: CPI 1993-1994

Data: Início de 1995

Idéia: Até 10 emendas individuais por parlamentar.

Interesse curto prazo: Não há

Frame: Eficiência técnica: "O grande número de emendas individuais dificulta uma apreciação mais criteriosa e a seleção de prioridades. ..... Nos últimos anos, as emendas individuais foram limitadas sem maiores problemas. Em 1993, foram definidas emendas prioritárias para análise em número de 20. Em 1994, o rito sumário (resolução 2/93? Ou 2/94??) determinou a apresentação de apenas 25 emendas por parlamentar. Para 1995, embora formalizadas em número de 50, só 10 foram apreciadas pelos relatores"

6) Ator: Sugestões Finais Assessoria Técnica

Instância: CPI 1993-1994

Data: Início de 1995

Idéia: Mais critérios para natureza de emendas coletivas

Interesse curto prazo: Não há.

Frame: Representação dos interessees do Estado: "O critério de apresentação de emendas de bancada da alternativa A (assinadas por 1/3 da bancada estadual) Não tem sido suficiente para fazer com quem tais emendas reflitam de fato projetos de interesse estadual. Neste sentido, a alternativa B tem a vantagem de obrigar que haja uma reunião de bancada, com a conseqüente decisão conjunta das emendas prioritárias para a unidade da federação. Vale destacar que as alternativas existentes Não valorizam suficientemente as emendas de comissão, na forma de uma apreciação preferencial pela CMO, o que ampliaria efetivamente a participação das comissões técnicas."

7) Ator: Francisco Dornelles (PPR, oposição)

Instância: Emenda ao Projeto José Fogaça

Data: 23/8 /1995

Idéia: Ampliar para 30 emendas individuais por parlamentar

Interesse curto prazo: Reeleição

Frame: Eficiência Processual: “A redução do limite de emendas individuais de despesas ao orçamanto de 50 para 10 em nada beneficia o processo de revisão da proposta orçamentária do Executivo. Ao contrário, o prejudica, já que não permitirá ao parlamentar corrigir mais do que 10 "distorções" que encontre na proposta do Executivo"

8) Ator: Francisco Dornelles (PPR, oposição)

Instância: Emenda ao Projeto José Fogaça

Data: 23/8 /1995

Idéia: Ampliar para 40 emendas individuais por parlamentar

Interesse curto prazo: Reeleição

Frame: Eficiência Processual: “A redução do limite de emendas individuais de despesas ao orçamanto de 50 para 10 em nada beneficia o processo de revisão da proposta orçamentária do Executivo. Ao contrário, o prejudica, já que não permitirá ao parlamentar corrigir mais do que 10 "distorções" que encontre na proposta do Executivo"

9) Ator: Francisco Dornelles (PPR, oposição)

Instância: Emenda ao Projeto José Fogaça

Data: 23/8 /1995

Idéia: Ampliar para 50 emendas individuais por parlamentar

Interesse curto prazo: Reeleição

Frame: Eficiência Processual: "A redução do limite de emendas individuais de despesas ao orçamanto de 50 para 10 em nada beneficia o processo de revisão da proposta orçamentária do Executivo. Ao contrário, o prejudica, já que não permitirá ao parlamentar corrigir mais do que 10 "distorções" que encontre na proposta do Executivo"

10) Ator: Nelson Marquezelli (PTB, coalizão)

Instância: Emenda ao Projeto José Fogaça 
Data: 30/8/1995

Idéia: Ampliar para 100 emendas individuais por parlamentar

Interesse curto prazo: Reeleição

Frame: Representação: "O parlamentar deve ter liberdade para lutar pelos interesses de sua região"

11) Ator: Nelson Marquezelli (PTB, coalizão)

Instância: Emenda ao Projeto José Fogaça

Data: 30/8/1995

Idéia: Até 50 emendas individuais por parlamentar

Interesse curto prazo: Reeleição

Frame: Representação/Legitimidade da atividade parlamentar: "Inadmissível tal restrição à atividade parlamentar"

12) Ator: Fernando Bezerra(PTB, coalizão)

Instância: Comissão 2005

Data: 31/3/2005

Idéia: Reduzir número de emendas coletivas

Interesse curto prazo: Pertencimento à coalizão

Frame: Representação dos interesses do estado: "O número de emendas de bancada deve ser inferior ao de parlamentares da bancada. Isso é para dar um caráter ...de interesse geral do estado na emenda. Também serão impostos critérios mais rígidos para a aprovação de emendas de bancada: localização geográfica específica; repetição de emenda dos exercícios subseqüentes até a conclusão do seu objetivo ou seja, vamos supor que houvesse 5 emendas de bancada para cada estado; essas emendas terão que ser repetidas até a conclusão da obra. Uma vez que uma bancada decide pelo início da construção de uma estrada, pela ampliação de um porto, pelo investimento em um determinado setor, essa emenda deve repetir-se obrigatoriamente até a conclusão daquele projeto. Essa seria uma forma de garantir o interesse estadual ou regional. Pode ser até uma ligação entre estados, uma obra de interesse de mais de um estado, mas a emenda deve repetir-se até a conclusão dessa obra. Em tese, apresentaríamos no relatório a proposta de redução do número de emendas de bancada. Hoje o limite está em 18 ou 20; reduziríamos para 3 ou 5 emendas de bancada, embora eu saiba que alguns companheiros achem até que elas Não devam existir."

13) Ator: Fernando Bezerra (PTB, coalizão)

Instância: Comissão 2005

Data: 31/3/2005

Idéia: A favor de limitar o número de emendas coletivas

Interesse curto prazo: Pertencimento à coalizão

Frame: Representação dos Interesses do Estado: "Quero a redução do número de emendas coletivas e aumento do valor da emenda individual, ou até do número de emendas individuais. Temos hoje os "guarda-chuvas" e isso fica resolvido. O número de emendas de bancada deve ser inferior ao de parlamentares da bancada. Isso é para dar um caráter ...de interesse geral do estado na emenda. Também serão impostos critérios mais rígidos para a aprovação de emendas de bancada: localização geográfica específica; repetição de emenda dos exercícios subseqüentes até a conclusão do seu objetivo - ou seja, vamos supor que houvesse 5 emendas de bancada para cada estado; essas emendas terão que ser repetidas até a conclusão da obra. Uma vez que uma bancada decide pelo início da construção de uma estrada, pela ampliação de um porto, pelo investimento em um determinado setor, essa emenda deve repetir-se obrigatoriamente até a conclusão daquele projeto. Essa seria uma forma de garantir o interesse estadual ou regional. Pode ser até uma ligação entre estados, uma obra de interesse de mais de um estado, mas a emenda deve repetir-se até a conclusão dessa obra. Em tese, apresentaríamos no relatório a proposta de redução do número de emendas de bancada. Hoje o limite está em 18 ou 20; reduziríamos para 3 ou 5 emendas de bancada, embora eu saiba que alguns companheiros achem até que elas não devam existir."

14) Ator: Gilmar Machado (PT, coalizão)

Instância: Comissão 2005

Data: 31/3/2005

Idéia: Limitar a natureza de emendas de bancada

Interesse curto prazo: Pertencimento à coalizão

Frame: Corrupção: "Em relação às emendas de bancada, fazendo-se a média proporcional, está correto reduzir o número. Além disso, emendas precisam ser estruturantes. Temos de definir claramente o destino, para Não fazer uma emenda geral sobre ambulâncias para dividir depois" 
15) Ator: Gilmar Machado (PT, coalizão)

Instância: Comissão 2005

Data: 31/3/2005

Idéia: Limitar a natureza das emendas de comissão

Interesse curto prazo: Pertencimento à coalizão

Frame: Eficiência Processual/ Turf Wars: "A emenda tem de ser relativa ao tema da comissão, seNão cada um vai começar a inventar. No ano passado fiquei impressionado com a criatividade das comissões, cada uma querendo entrar em outras áreas para apresentar emendas. E os relatores setoriais têm de sentar com as comissões da área. Ainda Não consegui entender: os relatores setoriais Não vão às comissões para debates, e depois vem aquele punhado de coisas"

16) Ator: Pauderney Avelino (PFL, oposição)

Instância: Comissão 2005

Data: $31 / 3 / 2005$,

Idéia: A favor do aumento de valor de emendas de bancada

Interesse curto prazo: Pertencimento à oposição

Frame: Representação dos interesses do Estado: "Não podemos tratar os desiguais de forma igual. As emendas de estado rico e de estado pobre podem até ser na mesma quantidade, mas temos de criar critérios para distribuição dos recursos de forma desigual, haja vista que a distribuição do Fundo de Participação dos Estados é inversamente proporcional à população e à arrecadação de tributos no Estado, exatamente para se fazer um pouco mais de justiça."

17) Ator: Ronaldo Dimas (PSDB, oposição)

Instância: Comissão 2005

Data: 31/3/2005

Idéia: Contra redução do número de emendas de bancada

Interesse curto prazo: Pertencimento à oposição

Frame: Representação dos interesses do Estado: "Reduzir o número de emendas coletivas faz aumentar as desigualdades regionais. Essa é uma verdade, pois os estados pequenos vão além de um número predeterminado de emendas e ficam prejudicados com essa sugestão oferecida. É uma preocupação dos representantes de estados menores. Um dos maiores problemas brasileiros é a diferença entre as grandes e médias regiões e as pequenas, que têm poucos representantes no parlamento, e há apenas uma forma de corrigir essas distorções no orçamento: as emendas coletivas. É por esse caminho que os estados pequenos têm buscado diminuir as diferenças"

18) Ator: Ricardo Barros (PP, oposição)

Instância: Comissão 2005

Data: 5/4/2005

Idéia: Limitar o número de emendas individuais

Interesse curto prazo: Preferência deslocada (contrária à reeleição)

Frame: Eficiência Processual: "Proponho limitar para 30 o número de emendas individuais. ... As votações são complexas, o relator-geral recebe cerca de 3 mil emendas e é obrigado a dar parecer para todas. Por isso, estamos tentando reduzir o número de emendas, até porque as bancadas podem se articular e distribuir entre seus membros a apresentação de emendas."

19) Ator: José Chaves (PTB, coalizão)

Instância: Comissão 2005

Data: $7 / 4 / 2005$

Idéia: Execução obrigatória de emendas individuais

Interesse curto prazo: Reeleição

Frame: Representação: Não tenho uma idéia formada sobre as emendas impositivas. É evidente que era o desejo de todos. Penso que essa é uma questão de interesse público, mas volto a lembrar que, na LDO, vamos discutir esse assunto. .. E Não há como negar, numa transparência clara que esta Casa deve exercer, que essa questão de emenda individual, realmente, é um incomodo. A grande maioria Não entende da prática orçamentária...mas certamente lembra-se, em primeiro lugar,da sua emenda individual, por razões políticas que não cabem nesta discussão".

20) Ator: Ricardo Barros (PP, oposição)

Instância: Comissão 2005 
Data: $7 / 4 / 2005$

Idéia: Preservar a existência das emendas de comissão

Interesse curto prazo: Pertencimento à oposição

Frame: Epecializacao Técnica: "Foi discutido ontem que as emendas de comissão seriam apenas de remanejamento. A comissão analisa o orçamento da sua área temática e, se entender que deva remanejar recursos de uma área para outra, deve fazê-lo. Agora, Não seriam de acréscimo porque há uma opinião muito ampla de que deveriam ser suprimidas as emendas de comissão, mas entendo que se limitarmos as emendas de comissão às emendas de remanejamento, dentro da área temática da comissão, evidentemente, isso provocaria uma análise, uma reflexão mais própria de que realmente um determinado programa do governo Não foi bem atendido e, dentro daquela mesma área, os parlamentares da comissão vão encontrar uma fonte para suprir mais aquela necessidade porque, apenas para fazer uma emenda, para que uma área tenha mais atendimento, isso é muito Simples. Agora, quando você tem que buscar esse atendimento dentro do próprio orçamento do ministério, passa a ser uma análise mais complexa, mais técnica e mais frutífera, que a comissão temática tem todas as condições de fazer, e as emendas de comissão deixariam de concorrer com as emendas de bancada na busca dos recursos porque, é evidente, os problemas nacionais Não podem competir com os problemas regionais. ...Seria muito importante porque eliminaria o conflito da disputa de atendimento, o ministro pedindo o atendimento da sua emenda de comissão contra a bancada pedindo recursos para sua obra."

21) Ator: Sérgio Guerra (PSDB, oposição)

Instância: Comissão 2005

Data: $7 / 4 / 2005$

Idéia: Defesa da existência das emendas individuais

Interesse curto prazo: Reeleição

Frame: Representação dos interesses do Estado: "Foi uma maneira de o estado federal brasileiro chegar a centenas de municípios, bases esquecidas do país a que o governo federal Não consegue chegar na forma de investimentos. Por outro lado, ela gerou um mecanismo de conveniente apropriação pública. Participei de várias campanhas municipais no Nordeste, nas quais era tema de discurso a avaliação de programas feitos com emenda individual de deputados federais e senadores - mais os primeiros. Alguns diziam que os recursos tinham vindo, mas a obra Não tinha sido feita. Outros alegavam que os recursos tinham chegado, trazidos por determinado deputado, e a obra estaria pronta. Desse modo, a própria sociedade começou a desenvolver um trabalho de fiscalização e de avaliação dessas emendas."

22) Ator: Jorge Bittar (PT, Coalizão)

Instância: Comissão 2005

Data: $7 / 4 / 2005$

Idéia: Contra aumento do número de emendas individuais: manteria 20 por parlamentar

Interesse curto prazo: Preferência deslocada (contrária à reeleição)

Frame: Eficiência Processual: "Se pretendemos tornar obrigatória a execução das emendas individuais, Não sei se aumentar para 30 Não é um exagero, porque é um problema também para processar. Fiz a conta aqui: 30 vezes 600 parlamentares, entre deputados e senadores, são 18 mil emendas. E processar tudo isso, acompanhar a execução, Não é uma tarefa Simples. Eu talvez mantivesse as 20 emendas hoje, a que temos direito, até como forma de tornar mais exeqüível isso"

23) Ator: Sérgio Guerra (PSDB, oposição)

Instância: Comissão 2005

Data: 7/4/2005

Idéia: A favor de limitar a natureza das emendas individuais

Interesse curto prazo: Preferência deslocada (contrária à reeleição)

Frame: Eficiência Macroeconômica: "As emendas devem ser consistentes do ponto de vista macroeconômico. Quanto mais as identificarmos com políticas públicas gerais, melhores elas serão"

24) Ator: Sérgio Miranda (PC do B, coalizão)

Instância: Comissão 2005

Data: 7/4/2005

Idéia: Defesa do aumento do valor de emendas de comissão

Interesse curto prazo: Pertencimento à Coalizão

Frame: Representação Setorial: "Não concordo com a diminuição do papel e do sentido das emendas de comissão. São as emendas do Brasil. Não temos nenhuma forma de ajudar o Projeto Antártica, o Aramar ou a Rede Sarah se Não for por uma comissão, porque são emendas de projetos mais abrangentes. O que 
vem ocorrendo nos últimos orçamentos é a diminuição do valor das emendas de comissão. Aumentou-se excessivamente o valor das emendas de bancada, e as emendas de comissão vêm minguando. Mas dizermos que um tipo de emenda só pode ser de remanejamento e a outra Não, o que é isso? Não são emendas parlamentares? Uma é feita pela comissão, a outra feita por uma bancada. Penso que Não pode haver diferenciação de emendas. ... O medo que tenho é que sejamos criticados porque estamos "paroquializando" o orçamento, reforçando mais as emendas individuais. Então, o deputado vai ter 30 emendas individuais. Estamos diminuindo as emendas de bancada e restringindo as de comissão. ...Defendo a emenda individual. Mas tem de haver um equilíbrio com ela e as emendas estruturantes.... Serei um advogado das emendas de comissão. Não viabilizaremos nenhum projeto na área de Ciência e Tecnologia sem uma emenda de comissão importante para aquele setor."

25) Ator: João Leão (PP, oposição)

Instância: Comissão 2005

Data: 20/4/2005

Idéia: Contra limite ao número de emendas de bancada

Interesse curto prazo: Pertencimento à oposição

Frame: Representação dos interesses do Estado: "Pertenço à CMO há doze anos. Na Bahia, conseguimos executar os projetos Barreiras Norte, Nupeba, Riacho Grande, Brejos da Barra, Baixio de Irecê, Salitre, tudo isso com emendas parlamentares, com as emendas de bancada e algumas emendas individuais. Muitas vezes nos juntamos nesta comissão para dar viabilidade a um determinado projeto de irrigação na Bahia. AsSim também foi com a recuperação das BRs 135 e 242. Considero, então, 5 emendas por estado muito pouco. Poderíamos equalizar os valores dessas emendas parlamentares em função, por exemplo, do Fundo de Participacao dos Estados. Não é justo que os estados mais ricos tenham direito a mais, e os estados mais pobres fiquem com menos. Temos de analisar isso em função da população, efetuar um cálculo que venha beneficiar principalmente os estados em desenvolvimento."

26) Ator: Eduardo Valverde (PT, coalizão)

Instância: Comissão 2005

Data: 20/4/2005

Idéia: Fim das emendas individuais

Interesse curto prazo: Preferência deslocada (contrária à reeleição)

Frame: Corrupção: "Minha divergência é em relação à competência que deve ter a CMO para apresentar essas emendas. Creio que nosso papel deveria ser tão-somente de fiscalizar a aplicação do orçamento e de discutir as linhas gerais de investimento, os programas de investimento do governo, porque uma atuação pontual, fragmentada, muitas vezes localizada acaba deixando de dar rumo a uma percepção muito mais abrangente dos interesses nacionais. Não temos ainda condição política de fazer isso. Nossa história política se faz muito ainda em função dos interesses paroquiais, localizados. E talvez nossa cultura republicana e acumulada Não permita avançar no sentido de permitir que o Congresso e a CMO se limitem ao papel de fiscalizar, de cobrar ou discutir programa, mas nunca de apontar emenda, destinação de verba pública, porque esta Não é uma boa prática. Temos vários exemplos de obras que foram indiciadas por irregularidade pelo TCU e o último escândalo que ocorreu nesta casa, dos anões do orçamento"

27) Ator: Luiza Erundina (PSB, coalizão)

Instância: Emenda ao Projeto Ricardo Barros

Data: Maio/2006

Idéia: Fim das emendas individuais

Interesse curto prazo: Preferência deslocada (contrária à reeleição)

Frame: Participação, Corrupção, Anti-Barganha: Com a supressão das emendas individuais ao PLOA e suas alteracoes, busca-se eliminar uma das principais modalidades de relacoes obscuras entre parlamentares e interesses privados, bem como diferentes setores da administracao pública. Longe de se pretender ceifar a iniciativa e a criatividade dos representantes do povo, espera-se, com essa modificacao, valorizar o trabalho das comissões temáticas das duas casas e arregimentar os esforços das bancadas estaduais em torno das prioridades de cada unidade federativa. Na elaboracao do orçamento, de abrangencia nacional, é a visao de conjunto dos desafios do país que deve nortear os trabalhos de aperfeiçoamento da proposta encaminhada pelo Executivo. (...) Outro benefício evidente desta modificacao que ora propomos é a eliminacao da barganha que se estabelece sistematicamente entre o Executivo, que detém o controle da execução orçamentária, e o autor da emenda, quando se trata de descontingenciar as dotações e liberar os recursos das emendas já incluídas na lei em troca do apoio às proposições de iniciativa do Executivo, constrangendo o parlamentar e reduzindo seus graus de liberdade 
nas diversas formas de votacao das proposicoes em tramitacao no CN. Esta proposta é mais do que oportuna, dada a recorrência dos escândalos denunciados pela imprensa e a proximidade do período eleitoral, servindo como uma demonstração de que a renúncia a uma prerrogativa individual oferece uma perspectiva de generosidade que tem em vista objetivos muito mais amplos e perenes"

28) Ator: Sérgio Miranda (PC do B, coalizão)

Instância: Comissão 2005

Data: 20/4/2005

Idéia: Contra aumento de emendas individuais

Interesse curto prazo: Preferência deslocada (contrária à reeleição)

Frame: Representação: "Não sei qual é a opinião do Executivo quanto à questão da execução orçamentária, mas sabe qual é meu medo da ampliação das emendas individuais? É uma certa 'paroquialização' do orçamento, o orçamento pode ficar muito voltado para pequenas emendas"

29) Ator: Primeiras sugestões da Assessoria Técnica

Instância: CPI 1993-1994

Data: Início de 1995

Idéia: Priorização das emendas coletivas e limites à natureza das emendas coletivas

Interesse curto prazo: Não há.

Frame: Representação: “A forma de participação preconizada na proposta,via priorização das emendas coletivas, terá o salutar efeito de valorizar o trabalho e estimular uma participação mais efetiva das Comissões Técnicas e das bancadas."

30) Ator: Ricardo Barros (PP, oposição)

Instância: Comissão 2005

Data: 30/3/2005

Idéia: Limite à natureza de emendas de bancada

Interesse curto prazo: Preferência deslocada (contária ao pertencimento à oposição)

Frame: Representação: "Há uma apropriação individual das emendas coletivas (aumento das emendas partilhadas) e isto causa falta de isonomia entre os mandatos parlamentares na alocação dos recursos orçamentários."

31) Ator: Jorge Bittar (PT, coalizão)

Instância: Comissão 2005

Data: 31/3/2005

Idéia: A favor da limitação da naturezade emendas de bancada

Interesse curto prazo: Pertencimento à coalizão

Frame: Representação dos interesses do Estado: "A emenda de bancada teria de estar vinculada a algum mecanismo de planejamento estadual ou microrregional, ou seja, a algum estado da federação. Evidentemente, as emendas sucessivas têm de assegurar isso. Para se garantir a execução orçamentária, o Executivo e o Legislativo precisam estar minimamente de acordo sobre os objetivos do projeto. Caso contrário, haverá dificuldades na execução"

32) Ator: Fernando Bezerra (PTB, coalizão)

Instância: Comissão 2005

Data: 31/3/2005

Idéia: A favor de critérios mais rígidos para a aprovação de emendas de bancada

Interesse curto prazo: Pertencimento à coalizão

Frame: Representação dos interesses do Estado: "O número de emendas de bancada deve ser inferior ao de parlamentares da bancada. Isso é para dar um caráter ...de interesse geral do estado na emenda. Também serão impostos critérios mais rígidos para a aprovação de emendas de bancada: localização geográfica específica; repetição de emenda dos exercícios subseqüentes até a conclusão do seu objetivo ou seja, vamos supor que houvesse 5 emendas de bancada para cada estado; essas emendas terão que ser repetidas até a conclusão da obra. Uma vez que uma bancada decide pelo início da construção de uma estrada, pela ampliação de um porto, pelo investimento em um determinado setor, essa emenda deve repetir-se obrigatoriamente até a conclusão daquele projeto. Essa seria uma forma de garantir o interesse estadual ou regional. Pode ser até uma ligação entre estados, uma obra de interesse de mais de um estado, mas a emenda deve repetir-se até a conclusão dessa obra. Em tese, apresentaríamos no relatório a proposta de redução do número de emendas de bancada. Hoje o limite está em 18 ou 20; reduziríamos 
para 3 ou 5 emendas de bancada, embora eu saiba que alguns companheiros achem até que elas não devam existir."

33) Ator: Ricardo Barros (PP, oposição)

Instância: Comissão 2005

Data: $7 / 4 / 2005$

Idéia: Emendas de comissão devem respeitar áreas temáticas

Interesse curto prazo: Pertencimento à oposição

Frame: Especialização Técnica: "Foi discutido ontem que as emendas de comissão seriam apenas de remanejamento. A comissão analisa o orçamento da sua área temática e, se entender que deva remanejar recursos de uma área para outra, deve fazê-lo. Agora, não seriam de acréscimo porque há uma opinião muito ampla de que deveriam ser suprimidas as emendas de comissão, mas entendo que se limitarmos as emendas de comissão às emendas de remanejamento, dentro da área temática da comissão, evidentemente, isso provocaria uma análise, uma reflexão mais própria de que realmente um determinado programa do governo não foi bem atendido e, dentro daquela mesma área, os parlamentares da comissão vão encontrar uma fonte para suprir mais aquela necessidade porque, apenas para fazer uma emenda, para que uma área tenha mais atendimento, isso é muito simples. Agora, quando você tem que buscar esse atendimento dentro do próprio orçamento do ministério, passa a ser uma análise mais complexa, mais técnica e mais frutífera, que a comissão temática tem todas as condições de fazer, e as emendas de comissão deixariam de concorrer com as emendas de bancada na busca dos recursos porque, é evidente, os problemas nacionais não podem competir com os problemas regionais. ...Seria muito importante porque eliminaria o conflito da disputa de atendimento, o ministro pedindo o atendimento da sua emenda de comissão contra a bancada pedindo recursos para sua obra" 
Anexo III

Circulação de idéias sobre a organização da Comissão Mista de Orçamento, 1988-2008

Caso 1: Circulação de Idéias sobre o Poder do Relator-Geral para emendar o orçamento, 19882008

\begin{tabular}{|c|c|}
\hline & Poder do Relator-Geral para emendar o orçamento \\
\hline 1988 & -- \\
\hline Resolução 1/1991 (Maio/1991) & -- \\
\hline Resolução 1/1993 (Junho/1993) & -- \\
\hline Recomendações CPI (Janeiro/1994) & -- \\
\hline Resolução 2/1994 (Novembro/1994) & $\begin{array}{l}\text { As emendas de Relator-Geral que venham a ser formuladas com } \\
\text { vistas ao cumprimento de suas responsabilidades serão publicadas } \\
\text { como parte do relatório, com indicação do proponente e dos } \\
\text { respectivos fundamentos. }\end{array}$ \\
\hline Primeiras Sugestões da Assessoria Técnica (Início de 1995) & $\begin{array}{l}\text { A Relatoria Geral seria formada por um Colegiado composto de } \\
\text { um Relator-Geral e até sete Relatores Adjuntos a serem escolhidos } \\
\text { pelo Relator Geral, sendo um de cada subcomissão, os quais, sob a } \\
\text { coordenação do Relator-Geral, seriam responsáveis pela elaboração } \\
\text { do relatório, cabendo à Relatoria Geral consolidar as propostas dos } \\
\text { Relatores Setoriais, promover as correções que se fizerem } \\
\text { necessárias e eventuais ajustes em cumprimento do disposto no } \\
\text { parecer preliminar, vedada a apresentação de emendas que } \\
\text { contenham matéria nova. }\end{array}$ \\
\hline Sugestões Finais da Assessoria Técnica (Início de 1995) & $\begin{array}{l}\text { Divisão da proposta orçamentária por relatores setoriais e relator- } \\
\text { geral; as propostas e suas emendas seriam relatadas pelos relatores } \\
\text { setoriais (e apreciadas no âmbito de determinada subcomissão, ou } \\
\text { na comissão); os pareceres setoriais seriam posteriormente } \\
\text { submetidos a um novo parecer do RG,. O RG não poderá aprovar } \\
\text { ou efetuar modificações nos pareceres setoriais, salvo para fins de } \\
\text { consolidação e eventuais ajustes técnicos (corresponde às regras } \\
\text { atuais que, no entanto, não têm sido respeitadas). }\end{array}$ \\
\hline Projeto Paulo Bernardo (GT Fogaça, 14/3/1995) & $\begin{array}{l}\text { "O parecer do relator-geral será elaborado conjuntamente com oito } \\
\text { relatores adjuntos, designados pelo presidente da CMO, observados } \\
\text { os critérios da proporcionalidade partidária e da proporcionalidade } \\
\text { numérica de membros titulares da CMO estabelecido nos termos } \\
\text { do art. } 3 \text { desta resolução. .... } 2^{\circ} \text { : caberá ao RG consolidar as } \\
\text { propostas dos relatores adjuntos, promovendo os ajustes que se } \\
\text { fizerem necessárias para o cumprimento do disposto no parecer } \\
\text { preliminar e na legislação em vigor; } 3^{\circ} \text { : somente poderão ser } \\
\text { incorporadas ao relatório como propostas de alteração do PLOA as } \\
\text { modificações que forem aprovadas pela maioria do colegiado } \\
\text { constituído pelo RG e relatores adjuntos; (...) } 5^{\circ} \text { : As emendas de } \\
\text { relator-geral que venham a ser formuladas com vistas ao } \\
\text { cumprimento de suas responsabilidades serão publicadas como } \\
\text { parte do relatório, com indicação do proponente e dos respectivos } \\
\text { fundamentos". }\end{array}$ \\
\hline Projeto Sérgio Guerra (GT Fogaça, 7/4/1995) & $\begin{array}{l}\text { "Caberá ao RG do PLOA adequar os pareceres setoriais aprovados } \\
\text { e as alterações decorrentes de destaques aprovados, vedada a } \\
\text { aprovação de emendas já rejeitadas, bem como a apresentacao de } \\
\text { emenda de relator que implique inclusao de subprojetos ou } \\
\text { subatividades novos; ... As emendas de RG que venham a ser } \\
\text { formuladas com vistas ao cumprimento de suas responsabilidades } \\
\text { serão publicadas como parte do relatório, com os respectivos } \\
\text { fundamentos. }\end{array}$ \\
\hline Projeto José Fogaça (GT Fogaça, 8/6/1995) & $\begin{array}{l}\text { Art. 9, parág. } 1^{\circ} \text { : Caberá à relatoria-geral adequar os pareceres } \\
\text { setoriais aprovados e as alterações decorrentes de destaques } \\
\text { aprovados, vedada a aprovação de emendas já rejeitadas bem como } \\
\text { a apresentação de emenda de relator que implique inclusão de }\end{array}$ \\
\hline
\end{tabular}




\begin{tabular}{|c|c|}
\hline & $\begin{array}{l}\text { subprojetos ou subatividades novos...... As emendas de RG que } \\
\text { venham a ser formuladas com vistas ao cumprimento de suas } \\
\text { responsabilidades serão publicadas como parte do relatório, com os } \\
\text { respectivos fundamentos }\end{array}$ \\
\hline $\begin{array}{l}\text { Emendas da Coalizão ao Projeto José Fogaça (Junho a } \\
\text { Agosto/1995) }\end{array}$ & -- \\
\hline $\begin{array}{l}\text { Emendas da Oposição ao Projeto José Fogaça (Junho a } \\
\text { Agosto/1995) }\end{array}$ & -- \\
\hline $\begin{array}{l}\text { Substitutivo de Renan Calheiros ao Projeto José Fogaça } \\
\text { (Setembro/1995) }\end{array}$ & Mantém Projeto José Fogaça. \\
\hline Resolução 2/1995 (13/9/1995) & $\begin{array}{l}\text { Caberá à Relatoria Geral do projeto de lei orçamentária anual } \\
\text { adequar os pareceres setoriais aprovados e as alterações } \\
\text { decorrentes de destaques aprovados, vedada a aprovação de } \\
\text { emendas já rejeitadas, bem como a apresentação de emenda de } \\
\text { Relator, que implique inclusão de subprojetos ou subatividades } \\
\text { novos.... } \$ 5^{\circ} \text { AS emendas de Relator-Geral que venham a ser } \\
\text { formuladas com vistas ao cumprimento de suas responsabilidade } \\
\text { serão publicadas como parte do relatório, com os respectivos } \\
\text { fundamentos. }\end{array}$ \\
\hline Resoluçao 1/2001 (Outubro/2001) & $\begin{array}{l}\text { Art. } 27 \text {. Os Relatores somente poderão apresentar emendas à } \\
\text { despesa e à receita com a finalidade de: I - corrigir erros e } \\
\text { omissões de ordem técnica ou legal; II - agregar proposições com } \\
\text { o mesmo objetivo ou viabilizar o alcance de resultados pretendidos } \\
\text { por um conjunto de emendas. } \\
\S 1^{\circ} \text { É vedada a apresentação de emendas de Relator tendo por } \\
\text { objetivo a inclusão de subtítulos novos, bem como o acréscimo de } \\
\text { valores a dotações constantes no projeto de lei orçamentária, } \\
\text { ressalvado o disposto no inciso I do caput e no parecer preliminar. } \\
\$ 2^{\circ} \text { As emendas de Relator serão classificadas de acordo com a } \\
\text { finalidade, nos termos do parecer preliminar. }\end{array}$ \\
\hline Ofício de Paulo Bernardo, presidente da CMO (1/3/2005) & -- \\
\hline Idéias Iniciais de Ricardo Barros na Comissão 2005 (30/3/2005) & $\begin{array}{l}\text { Vedação da possibilidade de o relator-geral alterar as dotações } \\
\text { aprovadas nos relatórios setoriais, exceto para aumentar os seus } \\
\text { valores }\end{array}$ \\
\hline $\begin{array}{l}\text { Propostas da Coalizão na Comissão de Reforma Orçamentária } \\
\text { (Abril e Maio/2005) }\end{array}$ & Um propõe uma comissão para avaliar emendas de relator-geral \\
\hline $\begin{array}{l}\text { Propostas da Oposição na Comissão Reforma Orçamentária } \\
\text { (Abril e Maio/2005) }\end{array}$ & $\begin{array}{l}\text { Um propõe: "É vedado ao relator-geral propor I - aprovação de } \\
\text { emendas com parecer setorial pela rejeição; II - a aprovação de } \\
\text { emendas destinando recursos para despesas discricionárias, } \\
\text { ressalvado o disposto no parágrafo anterior. (Entao emendas } \\
\text { discricionárias só com aqueles } 10 \% \text { que estão no artigo anterior.)" }\end{array}$ \\
\hline Projeto Ricardo Barros (11/7/2005) & $\begin{array}{l}\text { Art. 52: O relatório preliminar será composto de duas partes; II - } \\
\text { Parte Especial, que conterá... orientações específicas referentes à } \\
\text { apresentação e apreciação de emendas, inclusive as de relator e } \\
\text { classificação das emendas de relator quanto à finalidade; } \\
\text { Art. 144: Os relatores somente poderão apresentar emendas à } \\
\text { programação da despesa com a finalidade de: I - corrigir erros e } \\
\text { omissões de ordem técnica ou legal; II - recompor, total ou } \\
\text { parcialmente, dotações canceladas, limitada a recomposição ao } \\
\text { montante originalmente proposto no projeto; III - atender às } \\
\text { especificações do parecer preliminar. Parág. Único: é vedada a } \\
\text { apresentação de emendas que tenham por objetivo a inclusão de } \\
\text { subtítulos novos, bem como o acréscimo de valores a dotações } \\
\text { constantes dos projetos, ressalvado o disposto no inciso I do caput } \\
\text { e nos pareceres preliminares. Art. 145: As emendas de relator serão } \\
\text { classificadas de acordo com a finalidade, nos termos dos pareceres } \\
\text { preliminares. }\end{array}$ \\
\hline
\end{tabular}




\begin{tabular}{|c|c|}
\hline $\begin{array}{l}\text { Emendas da Coalizão ao Projeto } \\
\text { (Setembro/2005, Maio e Novembro/2006) }\end{array}$ & -- \\
\hline $\begin{array}{l}\text { Emendas da Oposição ao Projeto } \\
\text { (Setembro/2005, Maio e Novembro/2006) }\end{array}$ & -- \\
\hline $\begin{array}{l}\text { Substitutivo de José Carlos Aleluia ao Projeto Ricardo Barros } \\
(30 / 5 / 2006)\end{array}$ & Mantém proposta de Ricardo Barros. \\
\hline Recomendações CPI Ambulâncias/Sanguessugas (Agosto/2006) & -- \\
\hline Resolução 1/2006 (Dezembro/2006) & $\begin{array}{l}\text { Art. 66. O Relator-Geral poderá propor, em seu relatório, } \\
\text { acréscimos e cancelamentos aos valores aprovados para as } \\
\text { emendas coletivas de apropriação nos pareceres setoriais, } \\
\text { utilizando as fontes de recursos definidas no Parecer Preliminar. } \\
\text { Parágrafo único. O cancelamento de que trata o caput não poderá } \\
\text { ser superior a } 10 \% \text { (dez por cento) do valor aprovado para cada } \\
\text { emenda no Parecer Setorial. } \\
\text { Art. 67. É vedado ao Relator-Geral propor a aprovação de } \\
\text { emendas com Parecer Setorial pela rejeição. } \\
\text { Art. 69. ...IV - anexar os espelhos das emendas de Relator, } \\
\text { acompanhados dos respectivos fundamentos técnicos e legais e do } \\
\text { demonstrativo dessas emendas por modalidade. } \\
\text { Art. 144. Os Relatores somente poderão apresentar emendas à } \\
\text { programação da despesa com a finalidade de: I - corrigir erros e } \\
\text { omissões de ordem técnica ou legal; II - recompor, total ou } \\
\text { parcialmente, dotações canceladas, limitada a recomposição ao } \\
\text { montante originalmente proposto no projeto III - atender às } \\
\text { especificações dos Pareceres Preliminares. Parágrafo único. É } \\
\text { vedada a apresentação de emendas que tenham por objetivo a } \\
\text { inclusão de programação nova, bem como o acréscimo de valores a } \\
\text { programações constantes dos projetos, ressalvado o disposto no } \\
\text { inciso I do caput e nos Pareceres Preliminares }\end{array}$ \\
\hline Projeto de DelcídioAmaral - PRN 4/2008 (18/12/2008) & -- \\
\hline
\end{tabular}


Caso 2: Circulação de Idéias sobre o Poder do Relator-Geral para estimar receitas, 1988-2008

\begin{tabular}{|c|c|}
\hline & Poder do Relator-Geral para estimar receitas \\
\hline 1988 & $\begin{array}{l}\text { Está implícito que CMO decidirá como organizar este aspecto. Apenas dispõe } \\
\text { sobre certas vinculações de receitas. }\end{array}$ \\
\hline Resolução 1/1991 (Maio/1991) & $\begin{array}{l}\text { Não dispõe sobre. Na prática, RG estima. Lembrar que sob hiperinflação é } \\
\text { praticamente impossível estimar a receita. }\end{array}$ \\
\hline Resolução 1/1993 (Junho/1993) & Não dispõe sobre. Na prática, RG estima. \\
\hline Recomendações CPI (Janeiro/1994) & $\begin{array}{l}\text { "Orçamentos das receitas serão avaliados pela Comissão de Finanças e } \\
\text { Tributação (CD) e Comissão de Assuntos Econômicos (SF)" }\end{array}$ \\
\hline Resolução 2/1994 (Novembro/1994) & RG e sete relatores-adjuntos são responsáveis pelo parecer preliminar. \\
\hline $\begin{array}{l}\text { Primeiras Sugestões da Assessoria Técnica (Início } \\
\text { de 1995) }\end{array}$ & -- \\
\hline $\begin{array}{l}\text { Sugestões Finais da Assessoria Técnica (Início de } \\
\text { 1995) }\end{array}$ & -- \\
\hline Projeto Paulo Bernardo (GT Fogaça, 14/3/1995) & 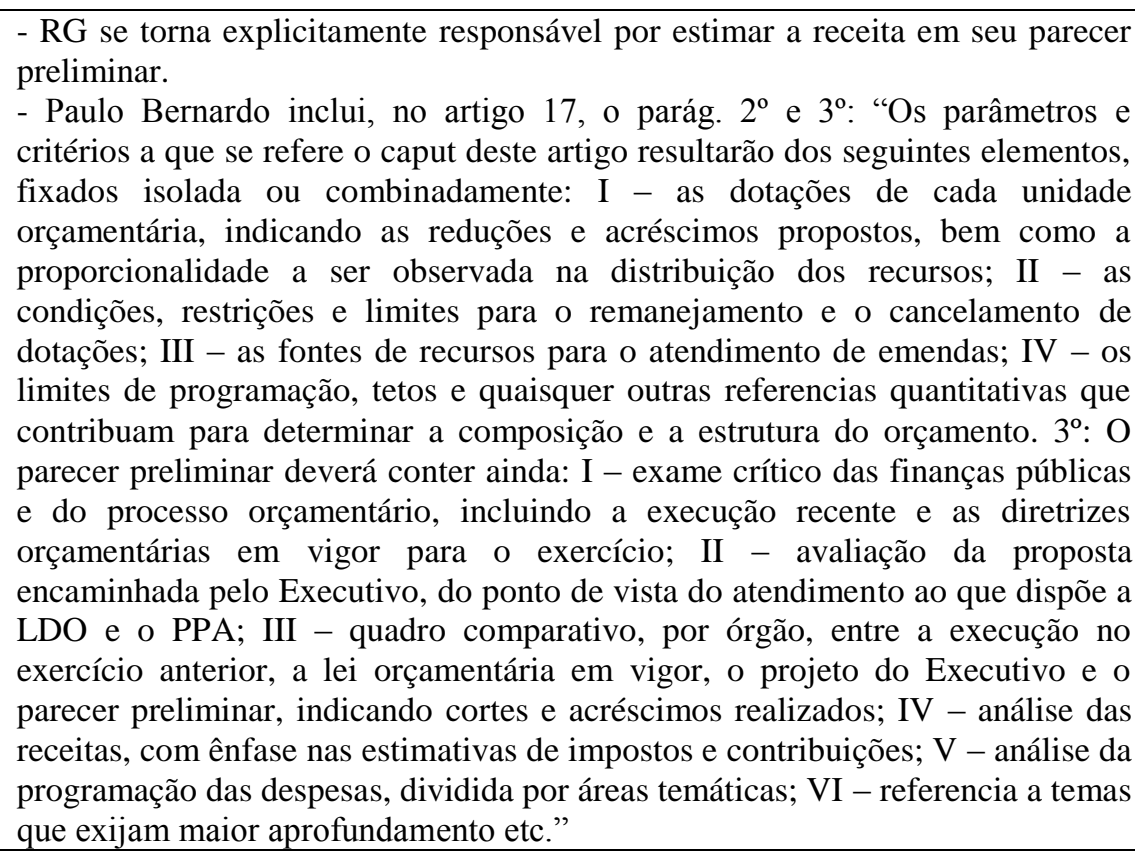 \\
\hline Projeto Sérgio Guerra (GT Fogaça, 7/4/1995) & Mantém Proposta de Paulo Bernardo. \\
\hline Projeto José Fogaça (GT Fogaça, 8/6/1995) & Mantém Proposta de Paulo Bernardo. \\
\hline $\begin{array}{l}\text { Emendas da Coalizão ao Projeto José Fogaça } \\
\text { (Junho a Agosto/1995) }\end{array}$ & -- \\
\hline $\begin{array}{l}\text { Emendas da Oposição ao Projeto José Fogaça } \\
\text { (Junho a Agosto/1995) }\end{array}$ & -- \\
\hline $\begin{array}{l}\text { Substitutivo de Renan Calheiros ao Projeto José } \\
\text { Fogaça (Setembro/1995) }\end{array}$ & Mantém Proposta de Paulo Bernardo. \\
\hline Resolução 2/1995 (13/9/1995) & Mantém Proposta de Paulo Bernardo. \\
\hline Resoluçao 1/2001 (Outubro/2001) & $\begin{array}{l}\text { Mantém Resolução } 1995 \text {. } \\
\text {-Art. 10. O projeto de lei do plano plurianual e o projeto de lei orçamentária } \\
\text { anual poderão ser divididos em até dez áreas temáticas, que ficarão a cargo dos } \\
\text { respectivos Relatores-Setoriais, nos termos do regulamento interno. Parágrafo }\end{array}$ \\
\hline
\end{tabular}


Ofício de Paulo Bernardo, presidente da CMO $(1 / 3 / 2005)$

Idéias Iniciais de Ricardo Barros na Comissão 2005

Propostas da Coalizão na Comissão de Reforma Orçamentária (Abril e Maio/2005)

Propostas da Oposição na Comissão Reforma Orçamentária (Abril e Maio/2005) $(30 / 3 / 2005)$

único. Na apreciação, na Comissão, do projeto de lei orçamentária anual, a análise da parte relativa à receita, à reserva de contingência e ao texto da lei ficarão a cargo do Relator-Geral

- Cria "comitê de avaliação da receita orçamentária", mas é coordenado pelo RG. "Serão constituídos até 5 comitês, sob a coordenação do Relator-Geral, com o mínimo de 3 e o máximo de 7 integrantes cada, para apoio aos RelatoresSetoriais e ao Relator-Geral do projeto de lei orçamentária. $\S 1^{\circ}$ Serão constituídos, pelo menos, os seguintes comitês: I - Comitê de Avaliação da Receita Orçamentária;.... $§ 2^{\circ}$ Cada comitê terá sua atribuição e número de membros fixados em ato da Comissão, sendo seus membros designados pelo Relator-Geral. $\S 3^{\circ}$ As conclusões e recomendações dos comitês estarão previamente disponíveis na Comissão e subsidiarão os Relatores-Setoriais e o Relator-Geral, sendo parte integrante do relatório final."

1) adotar na LDO normas que visem a compatiblização das metodologias de previsão dos Poderes Executivo e Legislativo quanto a receitas e despesas obrigatórias de forma a afastar a subavaliação de despesas obrigatórias na proposta orçamentária, principal causa do contingenciamento; atribuir responsabilidades às autoridades encarregadas da previsão; prever o envio antecipado pelo Executivo de previsões preliminares"

2) Restringir a possibilidade de se reestimar a receita a um único momento."

3) Segregar as funções de reestimativa da receita e de sua alocação, pelas alternativas: i) Atribuindo ao relator-geral a análise da receita e das despesas financeiras e obrigatórias nos termos do parecer preliminar (o acolhimento das emendas relativas a despesas discricionárias caberia exclusivamente às relatorias setoriais); ou ii) Atribuindo a uma relatoria específica a análise da receita".

1) Segregação das funções de reestimar e alocar, pela instituição da relatoria da receita; 2) Fixação de data-limite para a reestimativa da receita - 31/10.

Quatro são contra relator da receita; Dois são contra relator da receita indicado pela oposição; Dois são a favor do relator da receita

Entrepreneur Ricardo Barros é fortemente a favor da criação do Relator da Receita e do comitê permanente de avaliação da receita, mobilizando muitos enquadramentos diferentes (inicialmente quer que relator da receita seja indicado pela oposição, mas depois aceita que seja indicado de acordo com proporcionalidade partidária; Um parlamentar é a favor do relator da receita; um é contra relator da receita ; dois são contra relator da receita indicado pela oposição

Projeto Ricardo Barros (11/7/2005)
- Art. 16: A indicação e a designação dos relatores observará as seguintes disposições: I - do RG e do relator da receita do PLOA....será procedida de acordo com a indicação das lideranças partidárias; ...IV - as funções de RG e .... serão exercidas a cada ano, alternadamente, por representantes do SF e da $\mathrm{CD}$; V - o relator da receita não poderá pertencer à mesma casa, partido ou bloco parlamentar do RG; VI - a indicação dos relatores setoriais do PLOA observará as indicações dos líderes partidários e os critérios de proporcionalidade partidária e a dos membros de cada Casa, na CMO; VII - os relatores setoriais serão indicados preferencialmente dentre os membros das comissões permanentes afetas às respectivas áreas temáticas ou dentre os que tenham notória atuação parlamentar nas respectivas políticas públicas; VIII - na designação dos relatores setoriais, será adotado o critério de rodízio de forma que não seja repetido, no ano subseqüente, o mesmo relator para a mesma área temática

- Art. 31: A avaliação da estimativa da receita orçamentária e das respectivas emendas é de competência do relator da receita. Parág. Único: o relatório da receita será votado previamente à apresentação do relatório preliminar do RG... Art. 32. O relatório da receita será elaborado com o auxílio do Comitê de Avaliação da Receita. Parág. Único: a metodologia a ser utilizada na análise da estimativa de receita deverá ser a estabelecida pela LDO. Art. 33: o montante 
Emendas da Coalizão ao Projeto Ricardo Barros (Setembro/2005, Maio e Novembro/2006)

Emendas da Oposição ao Projeto Ricardo Barros (Setembro/2005, Maio e Novembro/2006)

Substitutivo de José Carlos Aleluia ao Projeto Ricardo Barros (30/5/2006)

Recomendações CPI Ambulâncias/Sanguessugas (Agosto/2006)

Resolução 1/2006 (Dezembro/2006) de eventuais recursos adicionais decorrentes de reestimativas de receitas constará do relatório da receita, não se admitindo novas reavaliações após sua aprovação. Art. 34: o relator da receita indicará as variações positivas e negativas por natureza e fonte de recursos, não podendo propor, em seu relatório, o cancelamento, parcial ou total, de dotações constantes do PLOA. Art. 35: o relator da receita deverá avaliar, em seu relatório, o atendimento das normas constitucionais e legais pertinentes à receita orçamentária, especialmente quanto à compatibilidade do projeto com a lei do PPA, a LDO e a LRF.

- Art. 38: O relatório da receita deverá conter: I - exame da conjuntura macroeconômica e do endividamento e seu impacto sobre as finanças públicas; II - análise da evolução da arrecadação da receita e da avaliação da sua estimativa na proposta, com ênfase na metodologia e nos parâmetros utilizados; III - demonstrativo das receitas reestimadas, comparando-as com as constantes da proposta orçamentária, classificadas por natureza e fonte; IV demonstrativo das propostas de pareceres às emendas à receita e de renúncia de receitas; $\mathrm{V}$ - o montante de eventuais recursos adicionais decorrentes de reestimativas de receitas, discriminando as variações positivas e negativas por natureza e fonte de recursos; VI - indicação dos montantes de despesa a serem reduzidos no parecer preliminar, quando necessária; VII - a verificação do atendimento das normas constitucionais e legais pertinentes à receita orçamentária, nos termos do art. 35"

Luciano Castro (PL, coalizão) é contra indicacao do relator da receita pelas lideranças partidárias (do mesmo modo que o RG), e contra também o fato de o relator da receita "não poder pertencer à mêsma casa, partido ou bloco parlamentar do RG" 3/5/2006

Laura Carneiro (PFL, oposição) é contra o Legislativo seguir metodologia de cálculo de receita do Executivo: " $\mathrm{O} C \mathrm{CN}$ não deve simplesmente seguir a metodologia do Executivo, pois esse tem subestimado as receitas de forma recorrente. A utilizacao de metodologias diferentes proporciona a evolucao no cálculo da reestimativa"

Mantém proposta Ricardo Barros.

“ Estabelecer na legislação complementar ou na LDO:. iv) normas de compatibilização das metodologias de previsão de receitas e despesas obrigatórias pelo Exec. e Legisl. de modo a afastar a subavaliação de despesas obrigatórias e a reestimativa de receita, causas importantes do contingenciamento"

- Art. 16. A indicação e a designação dos Relatores observarão as seguintes disposições: I - as lideranças partidárias indicarão o Relator-Geral e o Relator da Receita do projeto de lei orçamentária anual, o Relator do projeto de lei de diretrizes orçamentárias e o Relator do projeto de lei do plano plurianual;.... V o Relator da Receita do projeto de lei orçamentária anual não poderá pertencer à mesma Casa, partido ou bloco parlamentar do Relator-Geral do projeto de lei orçamentária anual;

- Art. 18. Serão constituídos os seguintes comitês permanents: II - Comitê de Avaliação da Receita; $\S 1^{\circ}$ Os comitês serão constituídos por no mínimo 5 (cinco) e no máximo 10 (dez) membros, indicados pelos Líderes, não computados os relatores de que trata o $\S 4^{\circ} ; \S 2^{\circ} \mathrm{O}$ número de membros de cada comitê será definido pelo Presidente, ouvidos os Líderes; $\S 3^{\circ}$ Cada comitê contará com um coordenador, escolhido obrigatoriamente dentre seus membros; $\ldots \S 5^{\circ} \mathrm{O}$ Relator da Receita do projeto de lei orçamentária anual integrará e coordenará o comitê previsto no inciso II do caput.

- Art. 23. Ao Comitê de Avaliação da Receita cabe: I - acompanhar a evolução da arrecadação das receitas; II - analisar a estimativa das receitas constantes dos projetos de lei do plano plurianual e da lei orçamentária anual; III - analisar as informações encaminhadas pelo Tribunal de Contas da União concernentes à 


\begin{tabular}{|c|c|}
\hline & 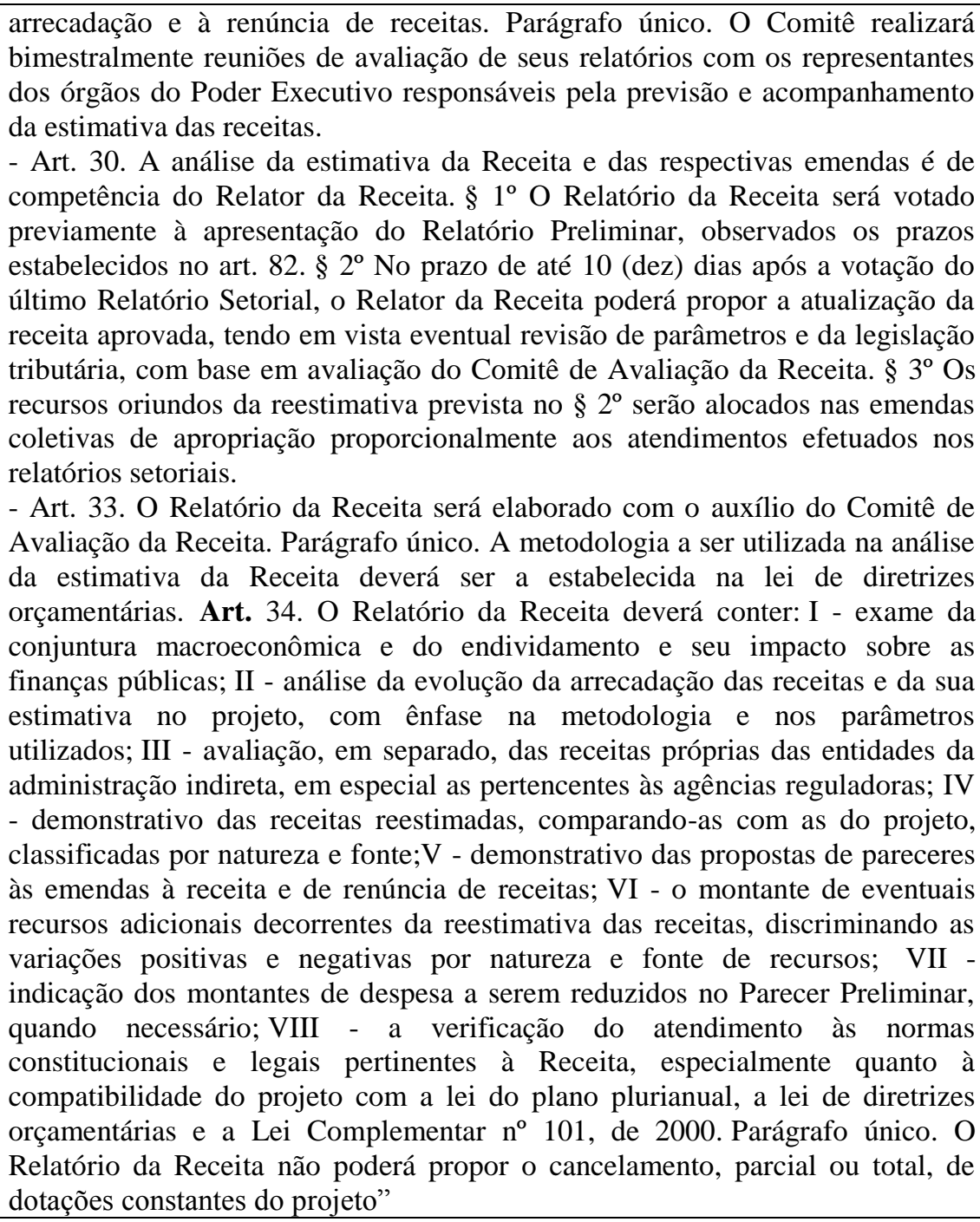 \\
\hline $\begin{array}{lllll}\text { Projeto de } & \text { DelcídioAmaral } & - & \text { PRN } & 4 / 2008 \\
(18 / 12 / 2008) & & & & \end{array}$ & $\begin{array}{l}\text { "A criação da relatoria da receita mostrou-se adequada, permitindo a discussão } \\
\text { antecipada e autônoma da receita. Como aperfeiçoamento, propõe-se a inserção } \\
\text { de dispositivo prevendo que os ajustes, na hipótese de reestimativa negativa da } \\
\text { receita, situação que ocorreu nos últimos dois anos, incidam em todo o projeto } \\
\text { de lei e suas alterações. Quando a segunda reestimativa for positiva, } \\
\text { entendemos que a regra da aplicação integral e proporcional do acréscimo aos } \\
\text { valores das emendas aprovadas pelos relatórios setoriais pode ampliar } \\
\text { distorções, engessando a ação da relatoria-geral e dificultando a correção de } \\
\text { despesas obrigatórias ou de erros e omissões identificados. Assim, propõe-se } \\
\text { nesse caso que os recursos da reestimativa sejam alocados nas emendas } \\
\text { coletivas, sendo que, no mínimo, } 80 \% \text { deve ser distribuído proporcionalmente } \\
\text { aos atendimentos efetuados nos relatórios setoriais, observado o limite } \\
\text { solicitado na emenda." }\end{array}$ \\
\hline
\end{tabular}


Caso 3: Circulação de Idéias sobre Poder para CMO, comissões temáticas ou subcomissões, 19882008

\begin{tabular}{|c|c|}
\hline & Poder para CMO, comissões temáticas ou subcomissões? \\
\hline 1988 & -- \\
\hline Resolução 1/1991 (Maio/1991) & $\begin{array}{l}\text { - Art. 21. A Comissão poderá criar subcomissões temáticas permanentes em } \\
\text { número nunca superior a oito, objetivando a racionalização dos seus trabalhos; } \\
\S 1^{\circ} \text { As matérias pertinentes a cada uma das Subcomissões poderão ser } \\
\text { apreciadas no seu âmbito antes da apreciação pelo Plenário da Comissão; } \S 2^{\circ} \\
\text { Os Projetos de Lei de Créditos Adicionais que contenham matéria da } \\
\text { competência de mais de uma Subcomissão poderão ser divididos para } \\
\text { apreciação das Subcomissões pertinentes; } \S 3^{\circ} \text { No caso do Projeto de Lei } \\
\text { Orçamentária Anual, os pareceres parciais serão apreciados em cada } \\
\text { Subcomissão especifica pertinente; } \S 4^{\circ} \text { Os pareceres setoriais aprovados pela } \\
\text { Subcomissão serão adequados pelo Relator-Geral da Lei Orçamentária Anual, } \\
\text { na forma do disposto no } \S 1^{\circ} \text { do art. } 10 \text {, e apreciados pelo Plenário da } \\
\text { Comissão'; } \S 5^{\circ} \text { Dentre as Subcomissões a que se refere o caput deste artigo é } \\
\text { criada, em caráter permanente, subcomissão incumbida de acompanhar e } \\
\text { fiscalizar a execução orçamentária, nos termos da CF, que atuará sem prejuízo } \\
\text { do exercício de atribuições semelhantes pelas outras subcomissões e pelas } \\
\text { demais Comissões do Congresso Nacional e de suas Casas; } \S 6^{\circ} \text { As atribuições } \\
\text { e composição das subcomissões serão estabelecidas pela Comissão; } \S 7^{\circ} \text { Na } \\
\text { composição de cada Subcomissão será obedecida a mesma representatividade } \\
\text { de cada uma das Casas do Congresso Nacional na Comissão e, sempre que } \\
\text { possível, a proporcionalidade partidária. } \\
\text { - Art. } 10 \S 2^{\circ} \text { Caso não haja constituição de subcomissões caberá ao Relator- } \\
\text { Geral da Lei Orçamentária Anual adequar os pareceres parciais aprovados, } \\
\text { vedada qualquer modificação, ressalvadas as alterações por ele propostas e } \\
\text { aprovadas pelo Plenário da Comissão. }\end{array}$ \\
\hline Resolução 1/1993 (Junho/1993) & $\begin{array}{l}\text { - Art. } 1^{\circ} \text { A Resolução } \mathrm{n}^{\circ} 1 \text {, de } 1991 \text { - CN passa a vigorar com as seguintes } \\
\text { alterações:... } \S 2^{\circ} \text { Com exceção do Presidente, cada membro titular da } \\
\text { Comissão será membro efetivo de duas das subcomissões temáticas de que } \\
\text { trata o art. } 21 \text { desta Resolução, excluída a subcomissão referida no seu } \S 5^{\circ} \text {. }\end{array}$ \\
\hline Recomendações CPI (Janeiro/1994) & $\begin{array}{l}\text { Extinção da CMO; LDO será discutida em todas as comissões técnicas } \\
\text { permanentes da Câmara e Senado; Propostas orçamentárias setoriais } \\
\text { (educação, saúde etc.) serão discutidas e elaboradas nas comissões técnicas da } \\
\text { CD e SF, com participação de representantes do Executivo. Serão reuniões } \\
\text { colegiadas de caráter misto; Comissões técnicas permanentes da CD e SF } \\
\text { fiscalizarão a execução dos projetos, sub-projetos e atividades; Será criada a } \\
\text { Comissão Parlamentar Mista de Sistematização Orçamentária (com disciplina } \\
\text { definida pelo regimento interno, não pela CF), que zelará pelo cumprimento } \\
\text { dos prazos de tramitação dos projetos e irá suprir deficiências das comissões } \\
\text { técnicas, além de consolidar as propostas setoriais. }\end{array}$ \\
\hline Resolução 2/1994 (Novembro/1994) & -- \\
\hline $\begin{array}{l}\text { Primeiras Sugestões da Assessoria Técnica (Início de } \\
\text { 1995) }\end{array}$ & $\begin{array}{l}\text { "Implementar a organização da Comissão Mista em subcomissões } \\
\text { permanentes, com até sete áreas temáticas. A subcomissão de fiscalização e } \\
\text { controle seria extinta, com as suas atribuições sendo exercidas pelas diversas } \\
\text { subcomissões, que seriam responsáveis, ainda, pela discussão e elaboração dos } \\
\text { pareceres setoriais da lei orçamentária e seus créditos adicionais, de acordo } \\
\text { com sua área temática" }\end{array}$ \\
\hline $\begin{array}{l}\text { Sugestões Finais da Assessoria Técnica (Início de } \\
\text { 1995) }\end{array}$ & $\begin{array}{l}\text { 1) escolha das relatorias setoriais (com a CMO estruturada ou não em } \\
\text { subcomissões permanentes - vide proposta } 2 \text { ) de modo que estas tenham } \\
\text { representantes das comissões técnicas permanentes do SF e da CD, os quais } \\
\text { operariam como interlocutores dos órgãos representados; } \\
\text { 2-A) Dividir a CMO em subcomissões permanentes, sendo, em princípio, } 6 \text { a } 8 \\
\text { áreas temáticas e uma de fiscalização e controle; tais subcomissões seriam } \\
\text { responsáveis pela discussão e votação das propostas de lei orçamentária e seus } \\
\text { créditos adicionais, de acordo com sua área temática (setor); } \\
\text { 2-B) igual à alternativa A, com a diferença de que a votação dos relatórios }\end{array}$ \\
\hline
\end{tabular}




\begin{tabular}{|c|c|}
\hline & setoriais seriam feitas no plenário da CMO, em vez de nas subcomissões. \\
\hline Projeto Paulo Bernardo (GT Fogaça, 14/3/1995) & $\begin{array}{l}\text { - Bernardo riscou parte do art. } 10 \text { da resolução, que dizia: "No caso de } \\
\text { designação dos relatores parciais para apresentação de seus relatórios à } \\
\text { subcomissão específica, serão indicados, também, relatores setoriais que } \\
\text { consolidarão os relatórios parciais, na forma do parág. } 3^{\circ} \text { do art. } 22 \text { desta } \\
\text { resolução, cabendo ao RG do PLOA adequar os pareceres setoriais aprovados } \\
\text { em cada subcomissão, vedada qualquer modificação de parecer setorial, } \\
\text { ressalvadas as alterações por ele propostas e aprovadas pelo plenário da CMO, } \\
\text { bem como as decorrentes de destaques aprovados pela CMO; } 2^{\circ} \text { caso não haja } \\
\text { constituição de subcomissões, caberá ao RG da LOA adequar os pareceres } \\
\text { parciais aprovados, vedada qualquer modificação, ressalvadas as alterações por } \\
\text { ele propostas e aprovadas pelo plenário da CMO". } \\
\text { - Paulo Bernardo apagou os trechos a seguir do art. } 22: \text { "A CMO poderá criar } \\
\text { subcomissões temáticas permanentes em número nunca superior a oito, } \\
\text { objetivando a racionalização dos seus trabalhos. } 1^{\circ} \text { : as matérias pertinentes a } \\
\text { cada uma das subcomissões poderão ser apreciadas no seu âmbito antes da } \\
\text { apreciação pelo plenário da CMO; } 2^{\circ} \text { : os projetos de lei de créditos adicionais } \\
\text { que contenham matéria da competência de mais de uma subcomissão poderão } \\
\text { ser divididos para apreciação das subcomissões pertinentes; } 3^{\circ}: \text { no caso do } \\
\text { PLOA, os pareceres parciais serão apreciadas em cada subcomissão específica } \\
\text { pertinente; } 4^{\circ} \text { : os pareceres setoriais aprovados pela subcomissão serão } \\
\text { adequados pelo RG da LOA, na forma do disposto no parág. } 1^{\circ} \text { do art. 10, e } \\
\text { apreciados pelo plenário da CMO; ... } 6^{\circ} \text { : as atribuições e composição das } \\
\text { subcomissões serão estabelecidas pela comissão; } 7^{\circ} \text { na na composição de cada } \\
\text { subcomissão será obedecida a mesma representatividade de cada uma das casas } \\
\text { do CN na CMO e, sempre que possível, a proporcionalidade partidária". } \\
\text { - Bernardo propõe (ou mantém) a subcomissão para acompanhar e fiscalizar a } \\
\text { execução orçamentária }\end{array}$ \\
\hline Projeto Sérgio Guerra (GT Fogaça, 7/4/1995) & $\begin{array}{l}\text { - Art. 24: "A CMO organizar-se-á em subcomissões temáticas permanentes em } \\
\text { número não superior a sete, objetivando a racionalização dos seus trabalhos, } \\
\text { cabendo às mesmas, dentre outras atribuições, apreciar os relatórios setoriais, } \\
\text { acompanhar e fiscalizar a respectiva execucao orçamentária, examinar as } \\
\text { prioridades e metas da LDO e realizar audiências públicas; } 1^{\circ} \text { : os projetos de } \\
\text { lei de créditos adicionais que contenham matéria da competência de mais de } \\
\text { uma subcomissão poderão ser divididos para apreciação das subcomissões } \\
\text { pertinentes, sem prejuízo de sua apreciação pela comissão; } 2^{\circ} \text { : os pareceres } \\
\text { setoriais aprovados pela subcomissão serão adequados pelo RG da LOA, na } \\
\text { forma do disposto no parág. } 1^{\circ} \text { do art. } 9 ; 3^{\circ} \text { : as demais atribuições e } \\
\text { composição das subcomissões serão estabelecidas pela CMO; } 4^{\circ} \text { cada } \\
\text { subcomissão será composta de pelo menos } 20 \text { membros titulares etc.; } 5^{\circ} \text { : o } \\
\text { presidente da CMO indicará coordenador de cada subcomissão; } 6^{\circ} \text { : os } \\
\text { pareceres dos relatores setoriais serão elaborados conjuntamente com até cinco } \\
\text { relatores setoriais por eles designados dentre os membros da subcomissão } \\
\text { respectiva, não podendo haver mais de dois relatores setoriais adjuntos } \\
\text { pertencentes ao mesmo partido ou bloco parlamentar". }\end{array}$ \\
\hline Projeto José Fogaça (GT Fogaça, 8/6/1995) & $\begin{array}{l}\text { - Art. 24: A CMO organizar-se-á em subcomissões temáticas permanentes em } \\
\text { número não superior a sete, objetivando a racionalização dos seus trabalhos, } \\
\text { cabendo às mesmas, dentre outras atribuições, apreciar os relatórios setoriais, } \\
\text { acompanhar e fiscalizar a respectiva execução orçamentária, examinar as } \\
\text { prioridades e metas da LDO e realizar audiências públicas. Art. 24, parág. } 1^{\circ} \text { : } \\
\text { os projetos de lei de créditos adicionais que contenham matéria da competência } \\
\text { de mais de uma subcomissão poderão ser divididos para apreciação das } \\
\text { subcomissões pertinentes, sem prejuízo da sua apreciação pela comissão. Art. } \\
24 \text {, parág. } 2^{\circ} \text { : os pareceres setoriais aprovados pela subcomissão serão } \\
\text { adequados pelo RG da LOA. Art. } 24 \text {, parág. } 3^{\circ} \text { : as demais atribuições e } \\
\text { composição das subcomissões serão estabelecidas pela comissão. Art. } 24 \text {, } \\
\text { parág. } 4^{\circ}: \text { cada subcomissão será composta de pelo menos } 20 \text { membros } \\
\text { titulares, sendo que, na sua composição, será obedecida a mesma } \\
\text { representatividade de cada uma das casas do CN e a proporcionalidade } \\
\text { partidária. Art. } 24 \text {, parág. } 5^{\circ} \text { : o presidente da CMO indicará, no âmbito de cada }\end{array}$ \\
\hline
\end{tabular}


Emendas da Coalizão ao Projeto José Fogaça (Junho a Agosto/1995)

Emendas da Oposição ao Projeto José Fogaça (Junho a Agosto/1995)

Substitutivo de Renan Calheiros ao Projeto José Fogaça (Setembro/1995)

Resolução 2/1995 (13/9/1995) subcomissão, um coordenador de seus trabalhos. Art. 24, parág. $6^{\circ}$ : os pareceres dos relatores setoriais serão elaborados conjuntamente com até cinco relatores setoriais adjuntos por eles designados dentre os membros da subcomissão respectiva, não podendo haver mais de dois relatores setoriais adjuntos pertencentes ao mesmo partido ou bloco parlamentar. $-$ $--$

-Art. 24: A CMO organizar-se-á em subcomissões temáticas permanentes em número não superior a sete, objetivando a racionalização dos seus trabalhos, cabendo às mesmas, dentre outras atribuições, apreciar os relatórios setoriais, acompanhar e fiscalizar a respectiva execução orçamentária, examinar as prioridades e metas da LDO e realizar audiências públicas. Art. 24, parág. $1^{\text {o }}$ : os projetos de lei de créditos adicionais que contenham matéria da competência de mais de uma subcomissão poderão ser divididos para apreciação das subcomissões pertinentes, sem prejuízo da sua apreciação pela comissão. (Eliminado) Art. 24, parág. $2^{\circ}$ : os pareceres setoriais aprovados pela subcomissão serão adequados pelo RG da LOA. Art. 24, parág. $3^{\circ}$ : as demais atribuições e composição das subcomissões serão estabelecidas pela comissão. Art. 24 , parág. $4^{\circ}$ : cada subcomissão será composta de pelo menos 20 membros titulares, sendo que, na sua composição, será obedecida a mesma representatividade de cada uma das casas do $\mathrm{CN}$ e a proporcionalidade partidária. Art. 24, parág. $5^{\circ}$ : o presidente da CMO indicará, no âmbito de cada subcomissão, um coordenador de seus trabalhos. Art. 24, parág. $6^{\circ}$ : os pareceres dos relatores setoriais serão elaborados conjuntamente com até cinco relatores setoriais adjuntos por eles designados dentre os membros da subcomissão respectiva, não podendo haver mais de dois relatores setoriais adjuntos pertencentes ao mesmo partido ou bloco parlamentar.

Art. 11. A Comissão organizar-se-á em subcomissões temáticas permanentes em número não superior a sete, objetivando a racionalização dos seus trabalhos, cabendo às mesmas, dentre outras atribuições, apreciar os relatórios setoriais, acompanhar a e fiscalizar a respectiva execução orçamentária, examinar as prioridades e metas da lei de diretrizes orçamentarias e realizar audiências públicas; $\S 1^{\circ}$ Os projetos de lei de créditos adicionais que contenham matéria da competência de mais de uma subcomissão poderão ser divididos para apreciação das subcomissões pertinentes, sem prejuízo da sua apreciação pela Comissão; $\S 2^{\circ}$ Cada subcomissão será composta de pelo menos vinte membros titulares, devendo, na sua composição, ser obedecida a mesma representatividade de cada uma das Casas do Congresso Nacional na Comissão e a proporcionalidade partidária; $\S 3^{\circ} \mathrm{O}$ Presidente da Comissão indicará, no âmbito de cada subcomissão, um Coordenador de seus trabalhos

Resolução 1/2001 (Outubro/2001)

- Art. 11. Serão constituídos até 5 (cinco) comitês, sob a coordenação do Relator-Geral, com o mínimo de 3 (três) e o máximo de 7 (sete) integrantes cada, para apoio aos Relatores-Setoriais e ao Relator-Geral do projeto de lei orçamentária. § $1^{\circ}$ Serão constituídos, pelo menos, os seguintes comitês: I Comitê de Avaliação da Receita Orçamentária; II - Comitê de Avaliação das Emendas; III - Comitê de Avaliação das Informações enviadas pelo Tribunal de Contas da União; $\S 2^{\circ}$ Cada comitê terá sua atribuição e número de membros fixados em ato da Comissão, sendo seus membros designados pelo Relator-Geral; $\S 3^{\circ}$ As conclusões e recomendações dos comitês estarão previamente disponíveis na Comissão e subsidiarão os Relatores-Setoriais e o Relator-Geral, sendo parte integrante do relatório final.

- Art. 46. A Comissão organizará a reunião conjunta de que trata o art. 9 , § 5, da Lei Complementar $n^{\circ} 101$, de 2000, em articulação com as demais comissões temáticas pertinentes das Casas do Congresso Nacional 


\begin{tabular}{|c|c|}
\hline $\begin{array}{l}\text { Ofício de Paulo Bernardo, presidente da CMO } \\
(1 / 3 / 2005)\end{array}$ & $\begin{array}{l}\text { 1) Criar Comitê de Acompanhamento e Fiscalização da Execução } \\
\text { Orçamentária em nível de resolução com a designação dos integrantes do } \\
\text { comitê de acordo com as relatorias setoriais do ano anterior; } \\
\text { 2) Dar exclusividade ao acolhimento das despesas discricionárias pelas } \\
\text { relatorias setoriais; } \\
\text { 3) Estabelecer limites e critérios à relatoria geral, no parecer preliminar, para } \\
\text { remanejamento e cancelamentos na programação constantes dos pareceres } \\
\text { setoriais se não adotado o critério acima; } \\
\text { 4) Obrigar a realização de audiência públicas com os relatores setoriais nas } \\
\text { Comissões Permanentes correspondentes }\end{array}$ \\
\hline $\begin{array}{l}\text { Idéias Iniciais de Ricardo Barros na Comissão } 2005 \\
(30 / 3 / 2005)\end{array}$ & $\begin{array}{l}\text { 1) eliminação das emendas de Comissão; } \\
\text { 2) emendas de Comissão atendidas somente pelo Relator-Geral; } \\
\text { 3) emendas de Comissão atendidas somente pelos relatores setoriais; audiência } \\
\text { dos relatores setoriais em todas as comissões que apresentarem emendas." }\end{array}$ \\
\hline $\begin{array}{l}\text { Propostas da Coalizão na Comissão de Reforma } \\
\text { Orçamentária (Abril e Maio/2005) }\end{array}$ & $\begin{array}{l}\text { Um é contra participação das comissões temáticas; Um é a favor do CAE; Um } \\
\text { é contra o CAE; Dois são contra comitê para acompanhar execução } \\
\text { orçamentária }\end{array}$ \\
\hline
\end{tabular}

Propostas da Oposição na Comissão Reforma

Orçamentária (Abril e Maio/2005)

R. Barros: CMO define macrodistribuicao de verbas e comissões temáticas cuidam do processo de emendamento etc., funcionando como as relatorias setoriais; é a favor de audiências públicas e participação das comissões temáticas; a favor de comitê para acompanhar execução orçamentário; Dois são a favor de comitê para acompanhar execução orçamentária; Um é a favor do fim da CMO; Um é a favor da participação das comissões temáticas; Um é a favor do Comitê de Avaliação da Receita e de Consistência Fiscal

Projeto Ricardo Barros (11/7/2005) - Art. 15. Ao presidente da CMO cabe: ...V - designar os relatores; VI designar os membros e coordenadores dos comitês; XI - declarar a inadmissibilidade das emendas

- Art. 18 Serao constituídos os seguintes comitês permanentes...I - Comitê de Avaliação, Fiscalizacao e Controle da Execucao Orçamentária; II - Comitê de Avaliação da Receita; III - Comitê de Avaliação das Informacoes sobre Obras e Serviços com Indícios de Irregularidades Graves; IV - Comitê de Exame de Admissibilidade das Emendas... Cada comitê terá um coordenador, escolhido obrigatoriamente dentre seus membros; Independentemente dos membros efetivos designados, os relatores setoriais e o RG integrarão o Comitê de Avaliação, Controle e Fiscalizacao da Execucao Orçamentária; Os comitês serao constituídos por no mínimo 5 e no máximo 10 membros; O relator da receita coordenará o Comitê de Avaliação da Receita.

- Art. 27: Poderao ser constituídos até dois comitês para apoio ao RG, com o mínimo de 3 e o máximo de 10 integrantes, sendo seus membros por ele indicados. Parág. Único: os comitês de que trata o caput terão sua atribuição e número de membros fixados em ato do presidente. Art. 28: a designação do conjunto dos membros e coordenadores dos comitês a que se refere esta seção obedecerá ao critério da proporcionalidade partidária e a de cada casa na CMO. - Art. 39: A participação das comissões permanentes da CD e SF no processo de apreciação do PLOA dar-se-á na forma do disposto no art. 90 do regimento comum e das disposições desta resolução. Art. 40: As comissões permanentes do SF e da CD cujas competências materiais sejam correlatas poderão, em conjunto, sugerir ao RG a inclusão, no relatório preliminar, de até três programas ou ações, por área ou subárea temática, para integrar a programação prioritária passível de emendas, nos termos do art. 52, II, " $k$ ". Parág. Único: As sugestões deverão observar as prioridades e metas estabelecidas na LDO e ser encaminhadas ao RG, por intermédio da secretaria da CMO, acompanhadas da ata de deliberação, no prazo de até cinco dias antes da data de apresentação do parecer preliminar.

Emendas da Coalizão ao Projeto Ricardo Barros (Setembro/2005, Maio e Novembro/2006)

Márcio Reinaldo Moreira (PP, coalizão) - 30/5/2006 - Suprima-se o art. 62 do substitutivo de Aleluia. Idéia é tornar relacionamento entre comissões e relatorias setoriais algo não-obrigatório. "O Art. 62 dispoe que os relatores setoriais debaterão o projeto de lei orçamentária nas comissões permanentes, antes da apresentacao de seus relatórios, observadas as áreas temáticas correspondentes, podendo ser convidados representantes da sociedade civil. A 


\begin{tabular}{|c|c|}
\hline & $\begin{array}{l}\text { ida de relator setorial a audiencia em comissao permanente não deveria ser } \\
\text { imposição legal e sim por convite do seu presidente, caso julgasse conveniente. } \\
\text { Os membros das comissões permanentes do SF e da CD serão convidados para } \\
\text { participar na CMO, da discussao dos relatórios setoriais, conforme previsto no } \\
\text { art. 63, dispensando assim a determinacao contida no art. 62" } \\
\text { - Alberico Filho (PMDB, coalizão) - } 30 / 5 / 2006 \text { - O substitutivo de Aleluia diz } \\
\text { o seguinte (art. 2, inciso IV, parág. } 2^{\circ} \text { ): A CMO poderá, para fins de } \\
\text { observancia do disposto no art. } 17 \text { da LRF, observados os regimentos internos } \\
\text { de cada Casa, antes da votacao nos respectivos plenários, ser ouvida acerca da } \\
\text { estimativa do custo e do impacto fiscal e orçamentário da aprovacao de } \\
\text { projetos de lei e medidas provisórias em tramitacao". Alberico Filho propoe } \\
\text { suprimir esse trecho. ("Esta emenda objetiva resguardar a atual competência } \\
\text { das outras comissões permanentes das casas do CN, sem a necessidade de } \\
\text { trâmite pela CMO, o que poderia dificultar o desenvolvimento do processo } \\
\text { legislativo") }\end{array}$ \\
\hline $\begin{array}{l}\text { Emendas da Oposição ao Projeto Ricardo Barros } \\
\text { (Setembro/2005, Maio e Novembro/2006) }\end{array}$ & $\begin{array}{l}\text { Laura Carneiro (PFL, oposição) - 13/9/2005 - CAE deve avaliar emendas aos } \\
\text { projetos de créditos adicionais }\end{array}$ \\
\hline $\begin{array}{l}\text { Substitutivo de José Carlos Aleluia ao Projeto Ricardo } \\
\text { Barros (30/5/2006) }\end{array}$ & Mantém Ricardo Barros. \\
\hline $\begin{array}{l}\begin{array}{l}\text { Recomendações } \\
\text { (Agosto/2006) }\end{array} \\
\text { CPI }\end{array}$ & $\begin{array}{l}\text { "Estabelecer na legislação complementar ou na LDO: i) criar Comissão Mista } \\
\text { de Fiscalização e Controle." }\end{array}$ \\
\hline Resolução 1/2006 (Dezembro/2006) & 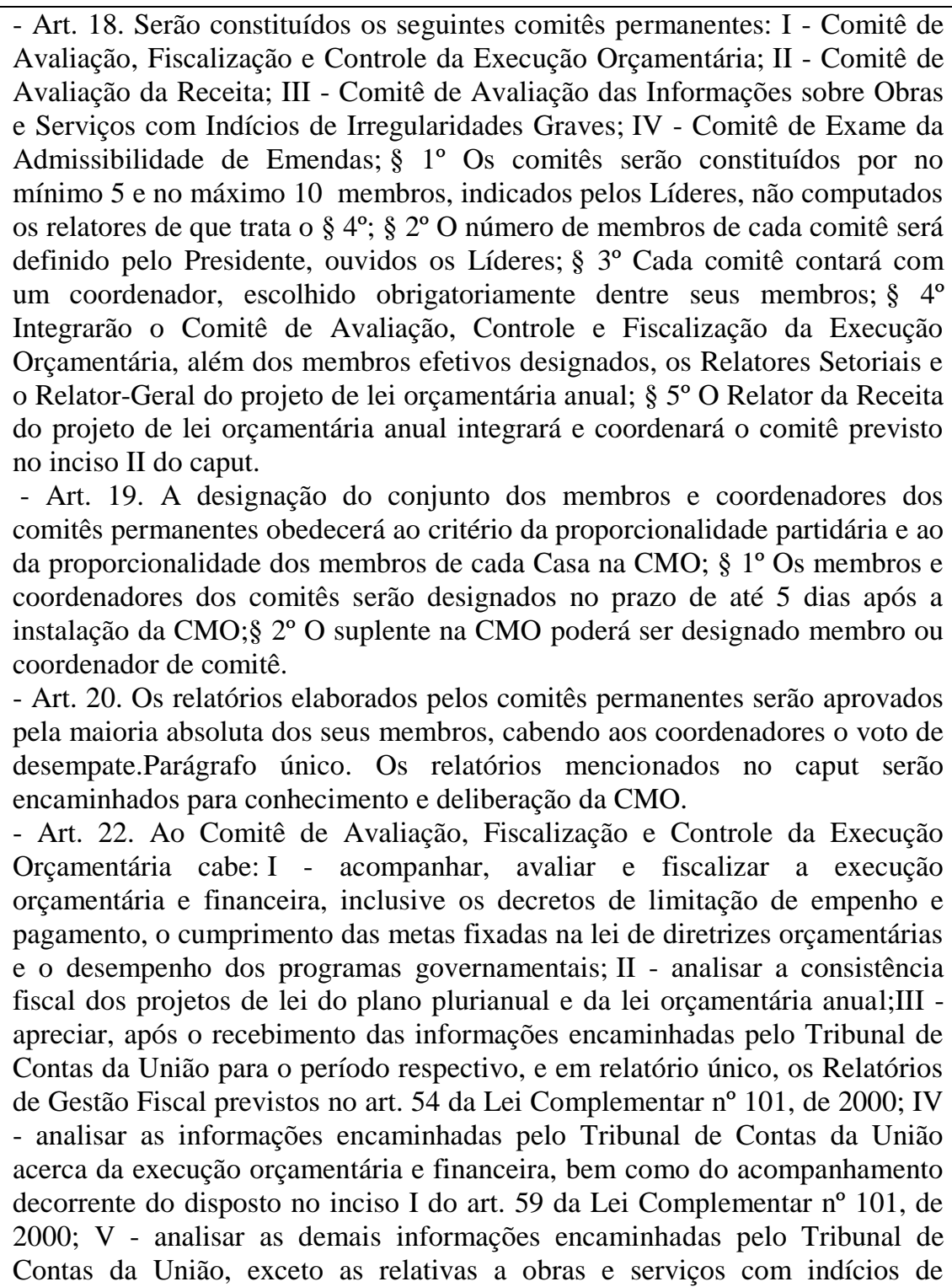 \\
\hline
\end{tabular}




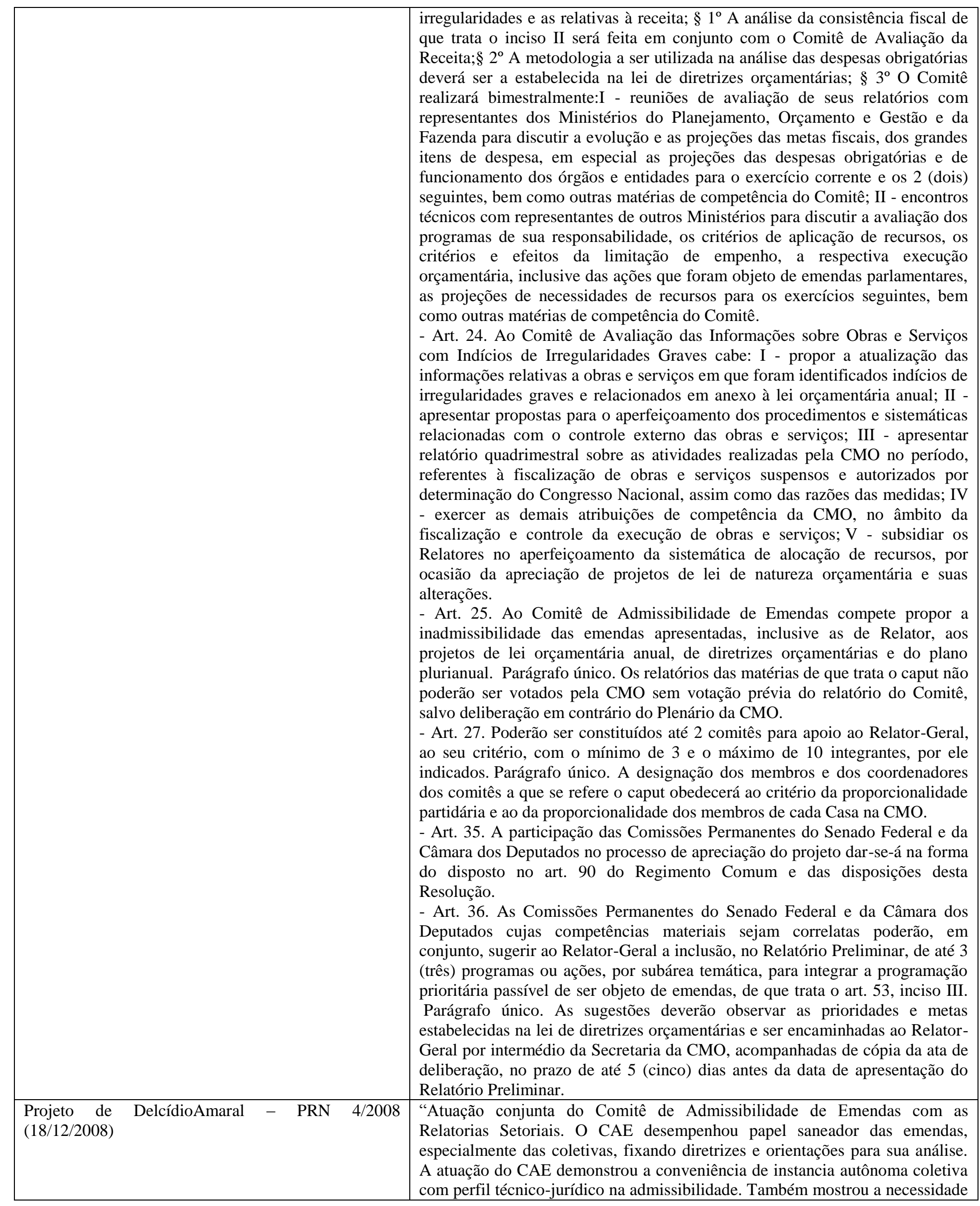


de prever sua atuação conjunta com as relatorias setoriais, especialmente no exame da admissibilidade das emendas individuais, o que contribui para a celeridade do processo." 
Caso 4: Circulação de Idéias sobre o Poder do Relator-Geral em relação aos Relatores Setoriais, 1988-2008

\begin{tabular}{|c|c|}
\hline & Poder dos Relatores Setoriais emrelação ao Relator-Geral \\
\hline 1988 & -- \\
\hline Resolução 1/1991 (Maio/1991) & $\begin{array}{l}\text { Art. 10. Compete ao Presidente,...., designar Relator-Geral do Projeto de Lei Orçamentária } \\
\text { Anual e o Relator do Projeto de Lei de Diretrizes Orçamentárias, de acordo com a indicação } \\
\text { das Lideranças Partidárias ou dos Blocos Parlamentares, bem como os demais Relatores que } \\
\text { se fizerem necessários aos trabalhos da Comissão, observado, sempre que possível, o critério } \\
\text { da proporcionalidade partidária; } \S 1^{\circ} \text { No caso de designação de Relatores-Parciais para } \\
\text { apresentação de seus relatórios à Subcomissão específica, serão indicados, também, } \\
\text { Relatores-Setoriais que consolidarão os relatórios parciais, na forma do } \S 3^{\circ} \text { do art. } 21 \text { desta } \\
\text { Resolução, cabendo ao Relator-Geral do Projeto de Lei Orçamentária Anual adequar os } \\
\text { pareceres setoriais aprovados em cada Subcomissão, vedada qualquer modificação de } \\
\text { parecer setorial, ressalvadas as alterações por ele propostas e aprovadas pelo Plenário da } \\
\text { Comissão, bem como as decorrentes de destaques aprovados pela Comissão; ....; } \S 5^{\circ} \text { Na } \\
\text { designação dos relatores parciais ou setoriais da Lei Orçamentária Anual será adotado o } \\
\text { critério de rodízio de forma que não seja repetido, no ano subseqüente, o mesmo relator para } \\
\text { a mesma unidade orçamentária. }\end{array}$ \\
\hline Resolução 1/1993 (Junho/1993) & -- \\
\hline Recomendações CPI (Janeiro/1994) & -- \\
\hline Resolução 2/1994 (Novembro/1994) & $\begin{array}{l}\text { Art. } 2^{\circ} \text { O projeto de lei a que se refere o artigo anterior será objeto, no âmbito da Comissão } \\
\text { Mista de Planos, Orçamentos Públicos e Fiscalização, de parecer do Relator-Geral do Projeto } \\
\text { de Lei Orçamentária Anual, elaborado conjuntamente com os sete Relatores Adjuntos } \\
\text { designados pelo Presidente da Comissão Mista. } § 1^{\circ} \text { Somente poderão ser incorporadas como } \\
\text { propostas de alteração do Projeto de Lei Orçamentária Anual as modificações que forem } \\
\text { aprovadas pela maioria do colegiado constituído pelo Relator-Geral e Relatores Adjuntos. }\end{array}$ \\
\hline $\begin{array}{l}\text { Primeiras Sugestões da Assessoria } \\
\text { Técnica (Início de 1995) }\end{array}$ & $\begin{array}{l}\text { Propõe-se que a análise do projeto de lei orçamentária seja feita por Relatores Setoriais e por } \\
\text { uma Relatoria Geral, definindo-se as atribuições de cada um. A proposta e suas emendas } \\
\text { seriam relatadas por Relatores Setoriais, indicados pelo Presidente da Comissão, e subscritas } \\
\text { pela maioria dos membros. Após, os pareceres setoriais seriam discutidos e votados em dois } \\
\text { turnos pelo plenário da Comissão. A Relatoria Geral seria formada por um Colegiado } \\
\text { composto de um Relator-Geral e até sete Relatores Adjuntos a serem escolhidos pelo Relator } \\
\text { Geral, sendo um de cada subcomissão, os quais, sob a coordenação do Relator-Geral, seriam } \\
\text { responsáveis pela elaboração do relatório, cabendo à Relatoria Geral consolidar as propostas } \\
\text { dos Relatores Setoriais, promover as correções que se fizerem necessárias e eventuais ajustes } \\
\text { em cumprimento do disposto no parecer preliminar, vedada a apresentação de emendas que } \\
\text { contenham matéria nova. }\end{array}$ \\
\hline $\begin{array}{l}\text { Sugestões Finais da } \\
\text { Técnica (Início de 1995) }\end{array}$ & $\begin{array}{l}\text { Alternativa a) (status quo na prática) Divisão da proposta orçamentária por relatores setoriais } \\
\text { e relator-geral; as propostas e suas emendas seriam relatadas pelos relatores setoriais (e } \\
\text { apreciadas no âmbito de determinada subcomissão, ou na comissão); os pareceres setoriais } \\
\text { seriam posteriormente submetidos a um novo parecer do RG, com possibilidade de } \\
\text { modificações e apresentação de novas emendas (corresponde à prática atual); } \\
\text { Alternativa b) (status quo formal) igual à alternativa anterior, diferenciada apenas na } \\
\text { atribuicao do RG, que não poderá aprovar ou efetuar modificações nos pareceres setoriais, } \\
\text { salvo para fins de consolidação e eventuais ajustes técnicos (corresponde às regras atuais } \\
\text { que, no entanto, não têm sido respeitadas); } \\
\text { Alternativa c) (Resolução 11/994) apenas uma relatoria-geral, formada por um colegiado } \\
\text { composto de um RG e, em principio, seis a oito relatores adjuntos; os relatores adjuntos, sob } \\
\text { a coordenação do relator, serao responsáveis pela elaboracao do relatório, dividido por áreas } \\
\text { temáticas distintas; caberá ao RG consolidar as propostas dos relatores adjuntos, promovendo } \\
\text { os ajustes que se fizerem necessários para o cumprimento do disposto no parecer preliminar; } \\
\text { questões substantivas que surgirem, não abordadas pelo parecer preliminar, serao } \\
\text { solucionadas mediante a decisão da maioria do colegiado (corresponde ao rito sumário } \\
\text { adotado na apreciação do orçamento para 1995). }\end{array}$ \\
\hline $\begin{array}{l}\text { Projeto Paulo Bernardo (GT Fogaça, } \\
\text { 14/3/1995) }\end{array}$ & $\begin{array}{l}\text { - Art. 17: "O RG da LOA apresentará parecer preliminar que, depois de aprovado pelo } \\
\text { plenário da CMO, estabelecerá os parâmetros e critérios que, obrigatoriamente, deverão ser } \\
\text { obedecidos...(na versão anterior, estava "pelos relatores parciais ou setoriais em seus } \\
\text { relatórios"; na versão de Paulo Bernardo, ficou: "pelo RG e pelos relatores adjuntos na } \\
\text { elaboração do parecer sobre o PLOA, inclusive quanto às emendas"). }\end{array}$ \\
\hline
\end{tabular}




\begin{tabular}{|c|c|}
\hline & $\begin{array}{l}\text { - Paulo Bernardo incluiu art. 19: "O parecer do RG DO PLOA será elaborado conjuntamente } \\
\text { com oito relatores adjuntos, designados pelo presidente da CMO, observados os critérios da } \\
\text { proporcionalidade partidária e da proporcionalidade numérica de membros titulares da CMO } \\
\text { estabelecido nos termos do art. } 3 \text { desta resolução. } 1^{\text {o: }} \text { os relatores adjuntos, sob a coordenação } \\
\text { do RG, serão responsáveis pela apreciação do projeto, dividido por áreas temáticas distintas; } \\
2^{\circ} \text { : caberá ao RG consolidar as propostas dos relatores adjuntos, promovendo os ajustes que } \\
\text { se fizerem necessárias para o cumprimento do disposto no parecer preliminar e na legislação } \\
\text { em vigor; } 3^{\circ} \text { : somente poderão ser incorporadas ao relatório como propostas de alteração do } \\
\text { PLOA as modificações que forem aprovadas pela maioria do colegiado constituído pelo RG } \\
\text { e relatores adjuntos" }\end{array}$ \\
\hline $\begin{array}{l}\text { Projeto Sérgio Guerra (GT Fogaça, } \\
\text { 7/4/1995) }\end{array}$ & $\begin{array}{l}\text { - Art. 9: "1 }{ }^{\circ} \text { : Caberá ao RG do PLOA adequar os pareceres setoriais aprovados e as } \\
\text { alterações decorrentes de destaques aprovados, vedada a aprovação de emendas já rejeitadas, } \\
\text { bem como a apresentacao de emenda de relator que implique inclusao de subprojetos ou } \\
\text { subatividades novos... } \\
\text { - Art. 16: "O RG do PLOA apresentará parecer preliminar que, depois de aprovado pelo } \\
\text { plenário da CMO, estabelecerá os parâmetros e critérios que, obrigatoriamente, deverão ser } \\
\text { obedecidos pelos relatores setoriais, pelo RG e pelos relatores adjuntos na elaboração do } \\
\text { parecer sobre o projeto de lei, inclusive quanto às emendas." } \\
\text { - Art. 19: "O parecer do RG do PLOA, com base nos pareceres dos relatores setoriais, será } \\
\text { elaborado conjuntamente com até sete relatores adjuntos por ele designados, sendo um de } \\
\text { cada subcomissão; } 1^{\circ} \text { : os relatores adjuntos, sob a coordenação do RG, terão a incumbência } \\
\text { de auxiliar a apreciação do projeto, dividido por áreas temáticas distintas, não podendo haver } \\
\text { mais de dois relatores adjuntos pertencentes ao mesmo partido ou bloco; } 2^{\circ} \text { : somente poderão } \\
\text { ser incorporadas ao relatório como propostas de alteração dos pareceres setoriais as } \\
\text { modificações que, devidamente justificadas, tenham sido aprovadas pela maioria do } \\
\text { colegiado constituído pelo RG e relatores adjuntos } \\
\text { - Art. 9, } 4^{\circ}: \text { "Na designação dos relatores setoriais, será adotado o critério de rodízio de } \\
\text { forma que não seja reptido, no ano subseqüente, o mesmo relator para a mesma área } \\
\text { temática". }\end{array}$ \\
\hline $\begin{array}{l}\text { Projeto José Fogaça (GT Fogaça, } \\
\text { 8/6/1995) }\end{array}$ & $\begin{array}{l}\text { - Art. 19: O parecer do RG do PLOA, com base nos pareceres dos relatores setoriais, será } \\
\text { elaborado conjuntamente com até sete relatores adjuntos por ele designados, sendo um de } \\
\text { cada subcomissão. Art. } 19 \text {, parág. } 1^{\circ}: \text { os relatores adjuntos, sob coordenação do RG, terão a } \\
\text { incumbência de auxiliar na apreciação do projeto, dividido por áreas temáticas distintas, não } \\
\text { podendo haver mais de dois relatores adjuntos pertencentes ao mesmo partido ou bloco. Art. } \\
\text { 19, parág. } 2^{\circ}: \text { somente poderão ser incorporadas ao relatório como propostas de alteração dos } \\
\text { pareceres setoriais as modificações que, devidamente justificadas, tenham sido aprovadas } \\
\text { pela maioria do colegiado constituído pelo RG e relatores adjuntos. Art. 19, parág. } 3^{\circ} \text { : Além } \\
\text { da programação da despesa de cada unidade orçamentária, integrarão o parecer sobre o } \\
\text { PLOA demonstrativo das alterações em relação à programação contida na proposta do } \\
\text { Executivo, por unidade orçamentária e por subprojeto ou subatividade, das emendas } \\
\text { aprovadas ou aprovadas parcialmente, em ordem alfabética de autor, informando-se os } \\
\text { respectivos valores aprovados. } \\
\text { - Art. 9, parág. } 1^{\circ} \text { : Caberá à relatoria-geral do PLOA adequar os pareceres setoriais } \\
\text { aprovados e as alterações decorrentes de destaques aprovados, vedada a aprovação de } \\
\text { emendas já rejeitadas bem como a apresentação de emenda de relator que implique inclusão } \\
\text { de subprojetos ou subatividades novos } \\
\text { - Art. } 9 \text {, parág. } 4^{\circ}: \text { Na designação dos relatores setoriais, será adotado o critério de rodízio de } \\
\text { forma que não seja repetido, no ano subseqüente, o mesmo relator para a mesma área } \\
\text { temática. }\end{array}$ \\
\hline $\begin{array}{l}\text { Emendas da Coalizão ao Projeto José } \\
\text { Fogaça (Junho a Agosto/1995) }\end{array}$ & $\begin{array}{l}\text { Nelson Marquezelli (PTB, coalizão) - 30/8/1995: 1) Relatores-adjuntos ao RG devem } \\
\text { pertencer a muitos partidos; 2) Rodízio de partidos nas principais relatorias; 3) Relatores } \\
\text { setoriais devem pertencer a muitos partidos; 4) Rodízio de relatores setoriais }\end{array}$ \\
\hline $\begin{array}{l}\text { Emendas da Oposição ao Projeto José } \\
\text { Fogaça (Junho a Agosto/1995) }\end{array}$ & -- \\
\hline $\begin{array}{l}\text { Substitutivo de Renan Calheiros ao } \\
\text { Projeto José Fogaça (Setembro/1995) }\end{array}$ & $\begin{array}{l}\text { - Art. 19: O parecer do RG do PLOA, com base nos pareceres dos relatores setoriais, será } \\
\text { elaborado conjuntamente com até sete relatores adjuntos por ele designados, sendo um de } \\
\text { cada subcomissão. Art. } 19 \text {, parág. } 1^{\circ} \text { : os relatores adjuntos, sob coordenação do RG, terão a } \\
\text { incumbência de auxiliar na apreciação do projeto, dividido por áreas temáticas distintas, não } \\
\text { podendo haver mais de dois relatores adjuntos pertencentes ao mesmo partido ou bloco. Art. } \\
\text { 19, parág. } 2^{\circ} \text { : somente poderão ser incorporadas ao relatório como propostas de alteração dos }\end{array}$ \\
\hline
\end{tabular}




\begin{tabular}{|c|c|}
\hline & $\begin{array}{l}\text { pareceres setoriais as modificações que, devidamente justificadas, tenham sido aprovadas } \\
\text { pela maioria do colegiado constituído pelo RG e relatores adjuntos. Art. } 19 \text {, parág. } 3^{\circ} \text { : Além } \\
\text { da programação da despesa de cada unidade orçamentária, integrarão o parecer sobre o } \\
\text { PLOA demonstrativo das alterações em relação à programação contida na proposta do } \\
\text { Executivo, por unidade orçamentária e por subprojeto ou subatividade, das emendas } \\
\text { aprovadas ou aprovadas parcialmente, em ordem alfabética de autor, informando-se os } \\
\text { respectivos valores aprovados. } \\
\text { - Art. } 9 \text {, parág. } 3^{\circ} \text { : na designação dos relatores setoriais, será adotado o critério de rodízio, de } \\
\text { forma que não seja repetido, no ano subsequiente, o mesmo relator para a mesma área } \\
\text { temática }\end{array}$ \\
\hline Resolução 2/1995 (13/9/1995) & 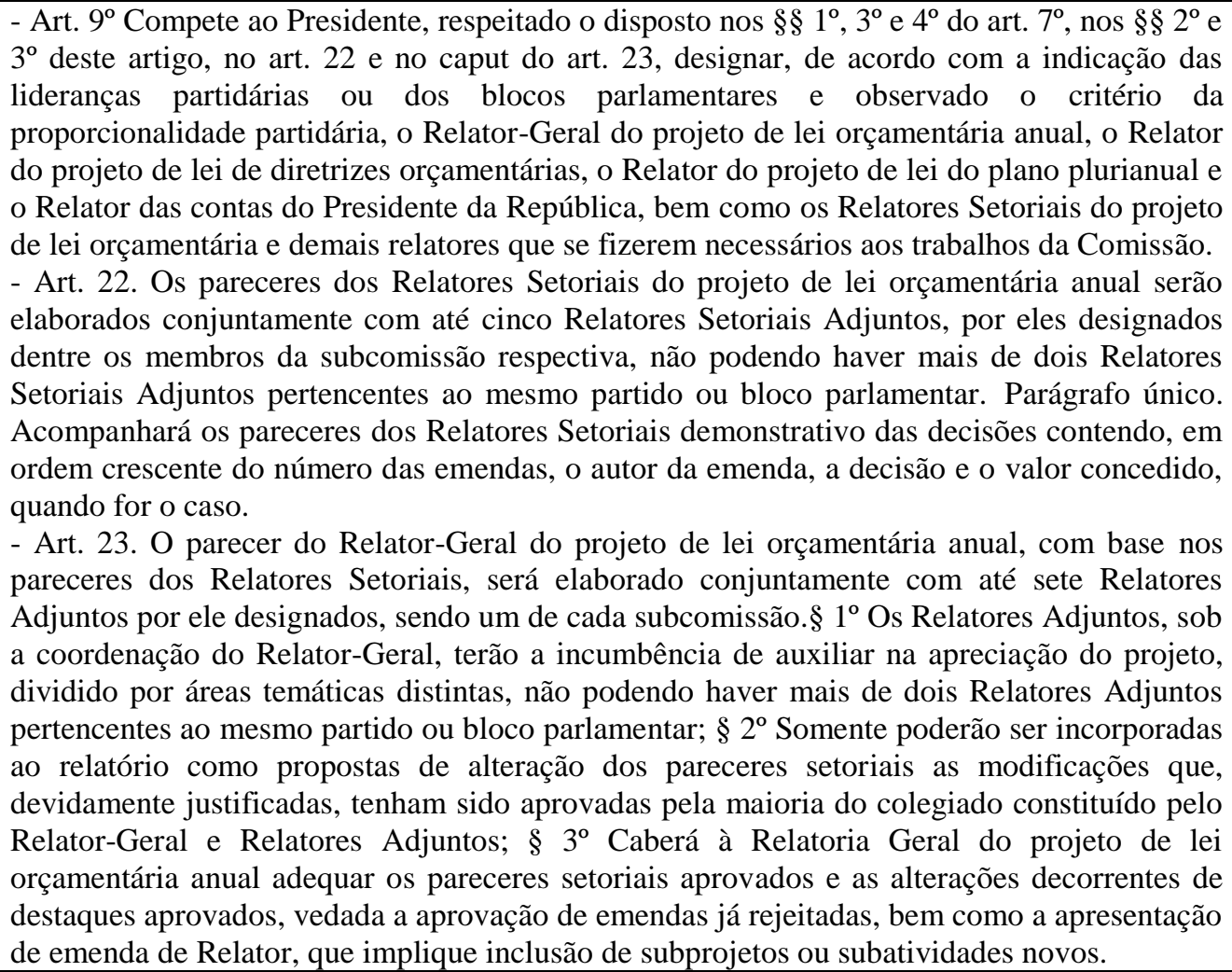 \\
\hline Resoluçao 1/2001 (Outubro/2001) &  \\
\hline $\begin{array}{l}\text { Ofício de Paulo Bernardo, presidente } \\
\text { da CMO }(1 / 3 / 2005)\end{array}$ & $\begin{array}{l}\text { 1) Fixar em resolução critérios para designação dos relatores setoriais; } \\
\text { 2) Dar exclusividade ao acolhimento das despesas discricionárias pelas relatorias setoriais; } \\
\text { 3) Estabeler limites e critérios à relatoria geral, no parecer preliminar, para remanejamento e } \\
\text { cancelamentos na programação constantes dos pareceres setoriais se não adotado o critério } \\
\text { acima; } \\
\text { 4) Obrigar a realização de audiência públicas com os relatores setoriais nas Comissões }\end{array}$ \\
\hline
\end{tabular}




\begin{tabular}{|c|c|}
\hline & Permanentes correspondentes. \\
\hline $\begin{array}{l}\text { Idéias Iniciais de Ricardo Barros na } \\
\text { Comissão } 2005(30 / 3 / 2005)\end{array}$ & $\begin{array}{l}\text { 1) Vedação da possibilidade de o relator-geral alterar as dotações aprovadas nos relatórios } \\
\text { setoriais, exceto para aumentar os seus valores; } \\
\text { 2) Definição, na resolução, dos percentuais da reestimativa de receita à disposição dos } \\
\text { relatores setoriais e do relator-geral; } \\
\text { 3)Vedação da possibilidade de o relator-geral alterar as dotações aprovadas nos relatórios } \\
\text { setoriais, exceto para aumentar os seus valores }\end{array}$ \\
\hline $\begin{array}{l}\text { Propostas da Coalizão na Comissão de } \\
\text { Reforma Orçamentária (Abril e } \\
\text { Maio/2005) }\end{array}$ & Um propõe manter o mesmo poder para o RG. \\
\hline $\begin{array}{l}\text { Propostas da Oposição na Comissão } \\
\text { Reforma Orçamentária (Abril e } \\
\text { Maio/2005) }\end{array}$ & $\begin{array}{l}\text { R. Barros: 1) mais poder para relatores setoriais; 2) Vedacao da possibilidade de o relator- } \\
\text { geral alterar dotações aprovadas nos relatórios setoriais exceto para aumentar seus valores ; } \\
\text { 3) definição na resolução dos percentuais da reestimativa de receita à disposição dos } \\
\text { relatores setoriais e do relator-geral, de modo que já ficasse clara a parcela de cada um; 4) } \\
\text { RG perde poder para definir algumas despesas que permitem "equalizar" os relatórios } \\
\text { setoriais; 5) A favor do rodízio de relatores setoriais; 6) Aumentar número de relatores } \\
\text { setoriais }\end{array}$ \\
\hline Projeto Ricardo Barros (11/7/2005) & 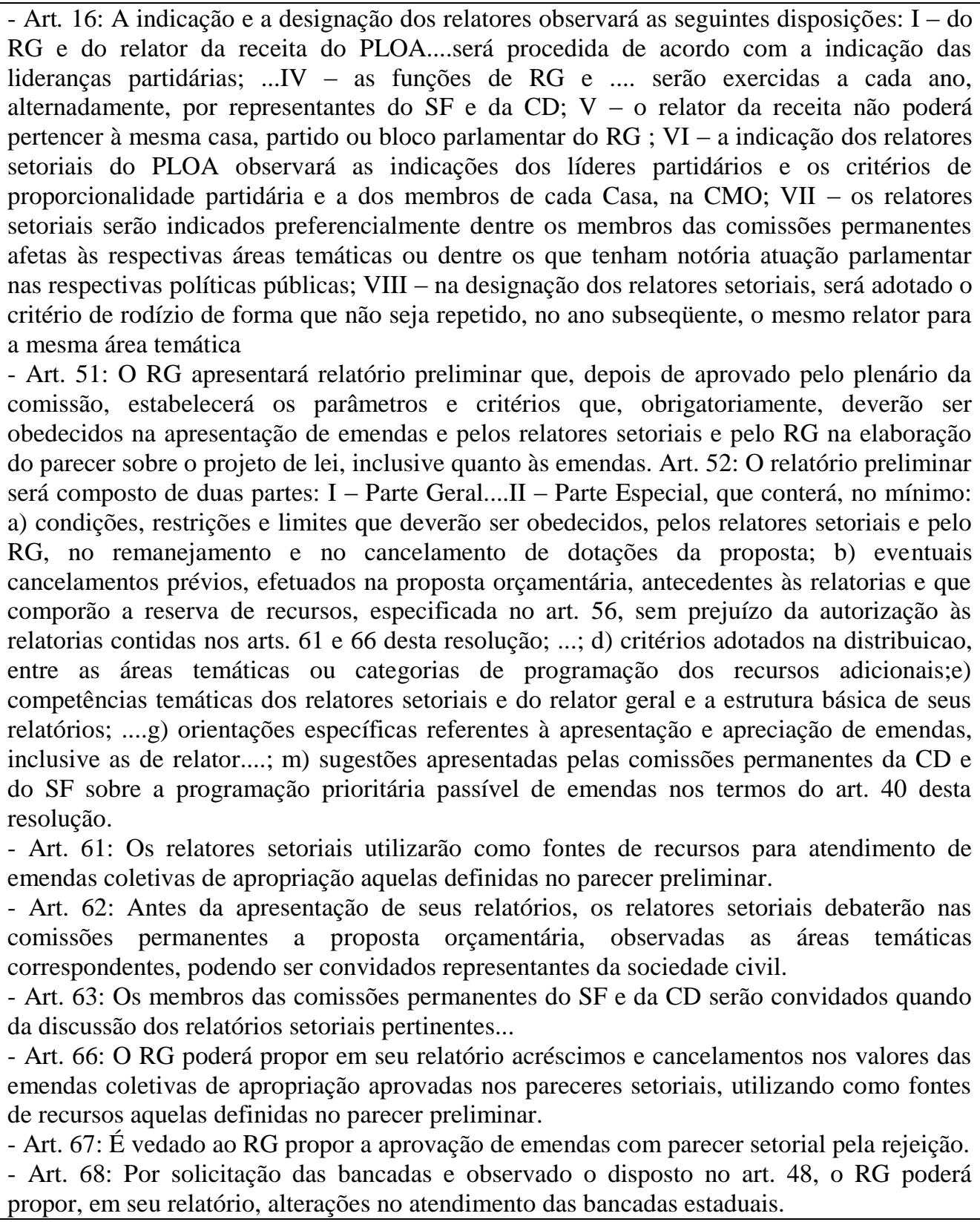 \\
\hline
\end{tabular}




\begin{tabular}{|c|c|}
\hline $\begin{array}{l}\text { Emendas da Coalizão ao Projeto } \\
\text { Ricardo Barros (Setembro/2005, Maio } \\
\text { e Novembro/2006) }\end{array}$ & $\begin{array}{l}\text { Um propõe } 3 \text { relatorias para SF, } 7 \text { para CD (em vez de } 4 \text { e 6); Um lembra da vinculação de } \\
\text { fontes para atendimento a emendas coletivas; Três, do PMDB, propõem rodízio individual } \\
\text { dos relatores setoriais (ou seja, contra o rodízio partidário) }\end{array}$ \\
\hline $\begin{array}{l}\text { Emendas da Oposição ao Projeto } \\
\text { Ricardo Barros (Setembro/2005, Maio } \\
\text { e Novembro/2006) }\end{array}$ & $\begin{array}{l}\text { Laura Carneiro: 1) Suprima-se o parág. } 1 \text { do art. } 57 \text {; 2) Art. } 57 \text {, inciso I: " } 25 \% \text { para emendas } \\
\text { de bancada, distribuídos no parecer preliminar" }\end{array}$ \\
\hline $\begin{array}{l}\text { Substitutivo de José Carlos Aleluia ao } \\
\text { Projeto Ricardo Barros (30/5/2006) }\end{array}$ & Mantém Ricardo Barros. \\
\hline $\begin{array}{l}\text { Recomendações } \\
\text { Ambulâncias/Sanguessugas } \\
\text { (Agosto/2006) }\end{array}$ & $\begin{array}{l}\text { "Criar mecanismos de alternância partidária nas relatorias da CMO, bem como a antecipação } \\
\text { na designação dos relatores setoriais e do Relator-geral" }\end{array}$ \\
\hline Resolução 1/2006 (Dezembro/2006) & 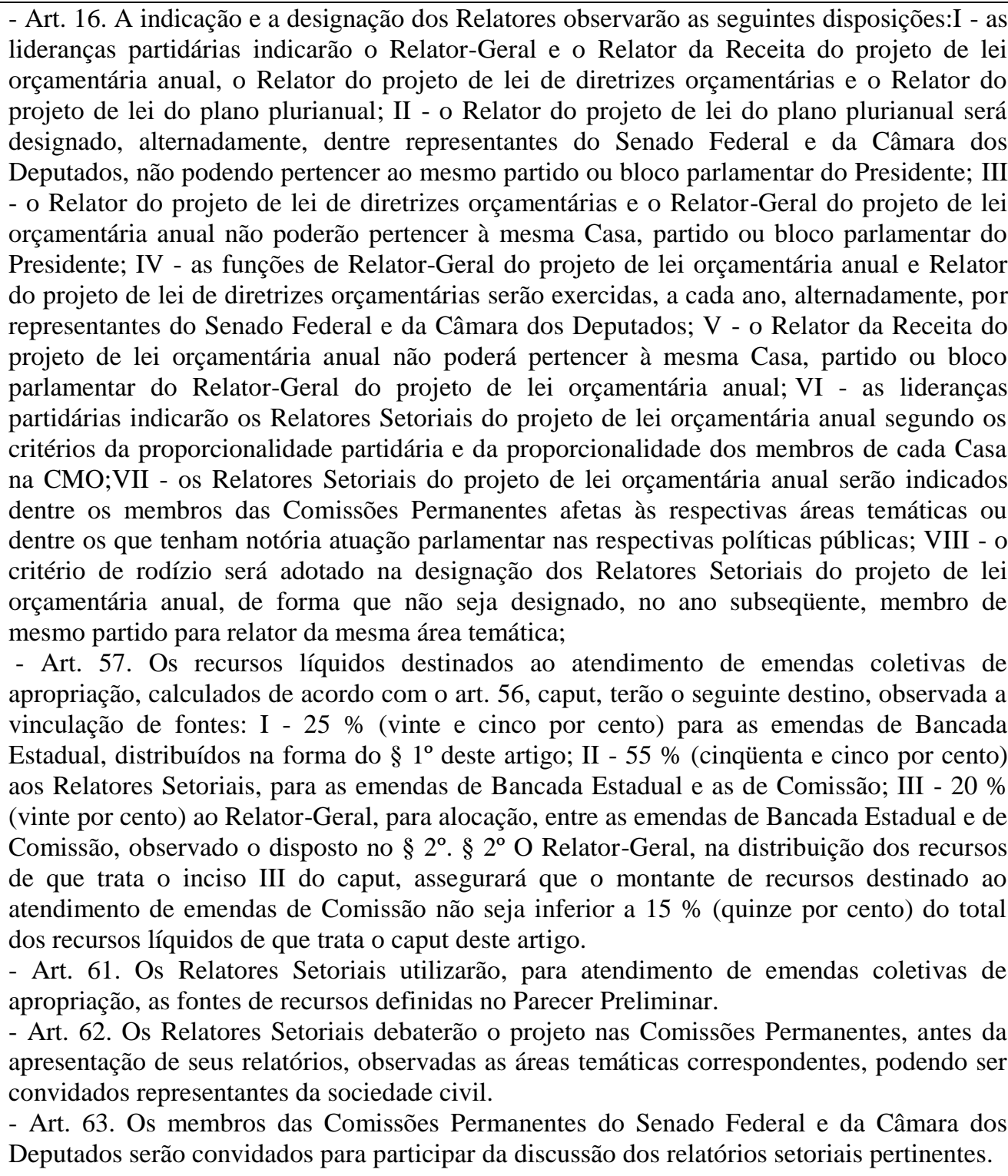 \\
\hline $\begin{array}{l}\text { Projeto de DelcídioAmaral }- \text { PRN } \\
4 / 2008(18 / 12 / 2008)\end{array}$ & -- \\
\hline
\end{tabular}




\section{Anexo IV}

\section{Enquadramentos discursivos (frames) sobre a organização da Comissão Mista de Orçamento}

1) Ator: Nelson Marquezelli (PTB, coalizão)

Instância: Emenda ao Projeto José Fogaça

Data: 30/8/1995

Idéia: Relatores-adjuntos ao Relator-Geral devem pertencer a muitos partidos

Interesse curto prazo: Preferência deslocada

Frame: "Participação": "Há necessidade de se promover mais discussão de idéias e programas de partidos com uma participação mais efetiva de cada um deles."

2) Ator: Nelson Marquezelli (PTB, coalizão)

Instância: Emenda ao Projeto José Fogaça

Data: 30/8/1995

Idéia: Rodízio de partidos nas principais relatorias

Interesse curto prazo: Preferência deslocada

Frame: "Participação da minoria": "Há a necessidade de maior participação de todos os partidos, quebrando-se a hegemonia dos maiores partidos que se consideram detentores da verdade e do conhecimento do que é bom para o Brasil."

3) Ator: Nelson Marquezelli (PTB, coalizão)

Instância: Emenda ao Projeto José Fogaça

Data: 30/8/1995

Idéia: Rodízio de relatores setoriais

Interesse curto prazo: Preferência deslocada

Frame "Representação": "O rodízio, evitando-se a repetição de relatores, é mais democrático, dando chance maior a todos os representantes do povo e dos estados, evitando-se a hegemonia dos "amigos do rei"

4) Ator: Gilmar Machado (PT, coalizão)

Instância: Comissão 2005

Data: 7/4/2005, p. 194

Idéia: Menos poder para o Relator-Geral

Interesse curto prazo: Preferência Deslocada

Frame "Participação/Transparência": "Dividir o poder do Relator-Geral é dar mais transparência e fazer com que o RG tenha de realizar debates mais abertos, possibilitando que os relatores setoriais tenham mais força e, ao mesmo tempo, debatam os projetos e os programas nas comissões temáticas. Isso fortalece e envolve a casa no debate do orçamento, o que, hoje, não temos. Envolver as comissões no debate geral do orçamento, não havendo apenas aquela reunião formal de definição de emendas, é algo importantíssimo e fundamental. Trata-se de democratizar, ampliando a participação da Casa e de todas as pessoas".

5) Ator: José Fogaça (PMDB, Coalizão)

Instância: Projeto de Resolução, 1995

Data: 8/6/1995

Idéia: Organização da CMO em subcomissões permenantes

Interesse curto prazo: Preferência Deslocada

Frame "Especialização": "A organização da CMO em subcomissões permanentes, divididas em até sete áreas temáticas, visa permitir uma maior especialização de parlamentares e corpo técnico, bem como um acompanhamento e análise sistemáticas da matéria orçamentária"

6) Ator: José Fogaça (PMDB, Coalizão)

Instância: Projeto de Resolução, 1995

Data: 8/6/1995

Idéia: Redefinição das atribuições do Relator-Geral

Interesse curto prazo: Preferência Deslocada

Frame Eficiência Processual: "Há agora uma definição clara das atribuições do Relator-Geral, que passa a ser o definidor das linhas mestras de apreciação dos vários setores pelas subcomissões e o sistematizador dos relatórios setoriais aprovados, vedada a inclusão de matéria nova pelo mesmo." 
7) Ator: Sérgio Miranda (PC do B, coalizão)

Instância: Comissão 2005

Data: 7/4/2005, p. $188-189$

Idéia: A favor do Comitê de Admissibilidade de Emendas

Interesse curto prazo: Preferência Deslocada

Frame Corrupção: "Acho interessante o Comitê de Admissibilidade de Emendas, que é admissibilidade do ponto de vista legal, não de conteúdo.Quando se fez a CPI do Orçamento, a questão que resultou em cassação de mandatos etc. foi a das emendas para as chamadas 'obras sociais'. Logo depois da CPI, a LDO foi muito restritiva para esse tipo de emenda. Mas as aberturas estão se ampliando. Então o comitê de admissibilidade de emendas deveria levar em conta também esses aspectos. Hoje o deputado cria uma obra social e ele mesmo coloca uma emenda para aquela obra. Há uma transferência direita e não se passa pelos comitês municipais criados pela LOAS, faz-se uma avaliação meramente contábil.. O presidente da CMO deve também assumir responsabilidades, não se pode concentrar tudo no relator-geral."

8) Ator: Ricardo Barros (PP, oposição)

Instância: Comissão 2005

Data: 30/3/2005

Idéia: Participação das comissões temáticas

Interesse curto prazo: Pertencimento à oposição

Frame Difusão: "Existem várias sugestões, como a possibilidade de a CMO, a exemplo do sistema americano, fazer apenas a macrodistribuicao de verbas - quanto é para a Educacao, por exemplo -, realizando receitas e alocação de despesas por área. E cada comissão temática, em conjunto com a subcomissão do Senado, faria a destinação específica daquela verba. Então as sub-relatorias passariam a ser as comissões temáticas instaladas na Câmara e Senado"

9) Ator: Ricardo Barros (PP, oposição)

Instância: Comissão 2005

Data: 20/4/2005, p. 31

Idéia: Participação das comissões temáticas

Interesse curto prazo: Pertencimento à oposição

Frame Participação Parlamentar: "Proponho que as audiências públicas aconteçam nas comissões temáticas. Então, em dois momentos, os membros das duas casas participarão do debate do orçamento. Primeiro, o relator setorial irá às comissões temáticas e debaterá a proposta do Executivo, ouvindo as sugestões dos membros dessas comissões. Depois, quando da discussão do relatório, na discussão que antecede a votação, também os membros das comissões permanentes da Camara e do Senado serão convidados a participar do debate, só não podendo votar por uma questão constitucional, mas poderão participar dos debates. De modo que os especialistas em cada uma das áreas, os quais são membros titulares das áreas temáticas.... poderão ter participação ativa na discussão do orçamento. Com isso, garantimos mais participação dos parlamentares"

10) Ator: Colbert Martins (PPS, oposição)

Instância: Comissão 2005

Data: 31/3/2005, p. 98-99

Idéia: Criação de subcomissões

Interesse curto prazo: Pertencimento à oposição

Frame Difusão: "Proponho a criação de uma estrutura forte de fiscalização e controle, uma subcomissão, ou um comitê, um órgão específico para acompanhar regularmente a execução orçamentária. Se isso não for feito, pouco avançaremos, porque relatores isolados terão seus trabalhos extremamente limitados. Nos Estados Unidos, cabe ao Congresso fazer esse acompanhamento. Hoje, aqui no Brasil, a execução do orçamento é totalmente controlada pelo Executivo. Com o contingenciamento e outras medidas do Executivo, ficamos totalmente a reboque de suas decisões."

11) Ator: Pauderney Avelino (PFL, oposição)

Instância: Comissão 2005

Data: 31/3/2005, p. 111-112

Idéia: Criação/manutenção de subcomissões

Interesse curto prazo: Pertencimento à oposição

Frame Barganha Política e Difusão: “A execução das despesas discricionárias talvez seja um dos principais problemas que temos enfrentado na $\mathrm{CMO}$ porque os governos tendem a utilizar os recursos 
aprovados no Congresso de forma política. Isso lamentavelmente acontece. Ocorre ao longo do ano uma barganha entre o Executivo e o Congresso. Gostaríamos sinceramente de ver sepultada essa prática. Na maioria das vezes, essa postura é motivo de novos problemas. No final do ano, vê-se uma farra de empenhos. Essa não é a melhor prática, para dizer o mínimo. Precisamos efetivamente fazer o acompanhamento dessa execução. Criamos um comitê de acompanhamento da execução orçamentária, mas o presidente nunca o instalou. Não temos condições de dizer que o orçamento impositivo seja a solução. Temos de buscar idéias boas onde quer que elas estejam, e para isso temos de buscar a experiência de outros países que já passaram por problemas como esses."

12) Ator: Ricardo Barros (PP, oposição)

Instância: Comissão 2005

Data: 5/4/2005, p. 137-139

Idéia: Extinção da $\mathrm{CMO} /$ poder para comissões temáticas

Interesse curto prazo: Pertencimento à oposição

Frame Especialização Parlamentar: "Temos uma proposta de alteração da composição da CMO: 56 membros titulares, sendo 42 deputados e 14 senadores. A idéia é que todos os parlamentares da Casa participem do orçamento. É ampliar a participação, reduzir o poder da CMO e, no futuro, as comissões temáticas funcionarem como relatores setoriais. A despesa de cada área será definida na comissão temática e por mais uma subcomissão equivalente do Senado. (p. 138)... Neste momento, o avanço é a exigência, na discussão do relatório setorial, que a audiência seja realizada em conjunto, ou seja, a comissão permanente temática e a subcomissão do Senado. Este ano, na discussão dos relatórios setoriais, teremos de convocar os membros da comissão permanente da $\mathrm{CD}$ e da subcomissão do Senado para que participem do debate. Não vão participar da deliberação, porque não será possível, mas participarão do debate. $\mathrm{O}$ debate do relatório setorial será realizado por especialistas, que são os parlamentares que se dedicam o ano inteiro àquela área e, na hora mais importante, ficam de fora. Portanto, passarão a participar da decisão, não nesse primeiro momento, quando vamos incluí-los na discussão, mas com a visão de poder transformar as comissões permanentes em relatores setoriais."

13) Ator: Colbert Martins (PPS, oposição)

Instância: Comissão 2005

Data: 7/4/2005, p. $189-190$

Idéia: Criação/Existência de subcomissões

Interesse curto prazo: Pertencimento à oposição

Frame Difusão: "Entendo ser necessário separar quem controla a receita de quem controla as despesas. Fiz pesquisas sobre alguns países, como a Alemanha e os Estados Unidos, e percebi que lá essa separação é bem nítida. Há uma comissão permanente de receita e uma outra comissão de orçamento, que executa, controla e fiscaliza as despesas. Creio que separar essas funções é algo extremamente interessante. Quanto ao comitê de consistência fiscal, é preciso que tenhamos avaliações permanentes do que está entrando de receita para que possamos ir para uma discussão que teremos adiante, que é a questão do contingenciamento. Minha proposta é que o contingenciamento tenha autorização legislativa para que possamos ter u maior poder para controlar a peça mais importante do parlamento, o orçamento.”

14) Ator: Ricardo Barros (PP, oposição)

Instância: Comissão 2005

Data: $12 / 4 / 2005$, p. 238

Idéia: Descentralização para comissões temáticas

Interesse curto prazo: Pertencimento à oposição

Frame Participação Parlamentar: "É evidente que estamos calçados nas alterações que obrigam os relatores a debater seus relatórios com as comissões setoriais. Não estamos restringindo, mas sim ampliando a participação dos deputados na discussão do orçamento. O relator setorial vai a cada comissão temática discutir a proposta do Executivo e suas alterações, e, no momento da apresentação do relatório aqui, durante a discussão que antecede a votação, as comissões temáticas também viriam participar do debate. O contexto geral é, portanto, de ampliação da participação dos parlamentares na discussão do orçamento. A sugestão para o futuro é que as próprias comissões temáticas votem os relatórios setoriais, mas no momento há um impedimento constitucional que não temos tempo de superar. Pretendemos propor essas alterações mais adiante."

15) Ator: Ricardo Barros (PP, oposição)

Instância: Comissão 2005

Data: 20/4/2005, p. 31 
Idéia: Mais poder para relatores setoriais

Interesse curto prazo: Pertencimento à oposição

Frame "Participação Partidária": "Os relatores setoriais passariam a ter mais poder: eles ficarão com $90 \%$ da alocação de recursos discricionários. Portanto, os partidos que indicam os relatores setoriais também terão mais responsabilidade."

16) Ator: Alberico Filho (PMDB, coalizão)

Instância: Emenda ao Projeto Ricardo Barros

Data: 30/5/2006

Idéia: A favor de rodízio individual dos relatores, ou seja, contra rodízio partidário nas relatorias setoriais Interesse curto prazo: Acesso a postos de poder institucional

Frame Participação/Proporcionalidade partidária: "Esta emenda objetiva manter, quanto à indicação e à designação dos relatores, o respeito ao princípio da proporcionalidade, permitindo aos partidos a livre escolha das áreas temáticas, restringindo apenas a repetição do relator, o que preserva o objetivo da alternância"

17) Ator: Henrique Eduardo Alves (PMDB, coalizão

Instância: Emenda ao Projeto Ricardo Barros

Data: Maio de 2006

Idéia: Rodízio de relatores setoriais deve ser individual, não partidário

Interesse curto prazo: Acesso a postos de poder institucional

Frame Proporcionalidade Partidária/Participação: "A emenda pretende disciplinar a distribuicao de relatores setoriais do PLOA de forma a possibilitar às bancadas partidárias optar pela área temática com que tenha mais afinidade, mesmo porque, ao restringir o direito de opção das bancadas, está se ferindo o princípio de proporcionalidade partidária na participação dos trabalhos das comissões, podendo desencadear um grave pretendente para outras comissões da casa"

18) Ator: Jorge Bittar (PT, coalizão)

Instância: Comissão 2005

Data: 7/4/2005, p. $187-188$

Idéia: Contra Comitê de Admissibilidade de Emendas

Interesse curto prazo: Pertencimento à coalizão

Frame Representação de Interesses dos Estados: "Minha dúvida na questão da avaliação das emendas é que mais à frente veremos que se pretende fortalecer o papel dos relatores setoriais e fazer com que as comissões permanentes dialoguem com os relatórios setoriais nos seus respectivos temas. Ainda fica de pé essa idéia? Isso significa que as despesas discricionárias, nas quais estão predominantemente vinculadas as emendas, serão tratadas de forma descentralizada. E aí fica prejudicado esse tempo. O que me parece importante é a questão do equilíbrio federativo, ou seja, que as emendas sejam distribuídas de maneira equânime entre os estados, o que pode ser feito pelo Relator-Geral. Não sei se haveria a necessidade de um comitê para tratar desse tema."

19) Ator: Sérgio Miranda (PC do B, coalizão)

Instância: Comissão 2005

Data: 20/4/2005, p. 50

Idéia: Avaliar emendas do Relator-Geral

Interesse curto prazo: Preferência Deslocada

Frame Justiça Procedimental: "O poder de inserção do relator-geral tem de ser inibido. Emenda de relator-geral tem de ser avaliada por uma comissão, tem de haver parecer sobre as emendas. Nossas emendas passam por esse aval, por que não as de relator-geral?"

20) Ator: Carlito Merss (PT, coalizão)

Instância: Comissão 2005

Data: 20/4/2005, p. 63

Idéia: Contra o relator da receita

Interesse curto prazo: Pertencimento à coalizão

Frame Eficiência Processual: "Essa questão do Relator da Receita, indicado pela minoria, acredito que vai partidarizar a discussão. Esse é o problema. Não é isso que queremos. Justamente, quais foram as crises que tivemos nos últimos anos? Disputas entre governo e oposição, que nos empurravam sempre para o final do ano, para fazer aquele trabalho de malucos, virando madrugadas, geralmente com a pressa para 
resolver receitas. Os últimos cinco ou seis relatores-gerais tiveram o mesmo problema: a pressão para descobrir receitas"

21) Ator: Iberê Ferreira (PTB, coalizão)

Instância: Comissão 2005

Data: $31 / 3 / 2005$, p. 100

Idéia: A favor do relator da receita

Interesse curto prazo: Preferência Deslocada

Frame: Barganha Política: "Concordo inteiramente com a indicação de dois relatores, o da receita e o da despesa. Tenho acompanhado o trabalho da CMO ao longo desses anos. Normalmente e à medida que a pressão aumenta...o relator chama 2, 3, 5 pessoas para conseguir aprovar a receita, visto que a pressão é enorme e só assim poderá fechar o orçamento. Um Relator de Receita vai nos dar condição para justificar a limitação do contingenciamento. O próprio governo não pode reclamar desde que haja um relator específico da receita, que irá apresentar seu relatório antes da elaboração orçamentária."

22) Ator: Jorge Bittar (PT, coalizão)

Instância: Comissão 2005

Data: 5/4/2005, p. 164

Idéia: ContraRelator da Receita

Interesse curto prazo: Pertencimento à coalizão

Frame: Corrupção: "Minha preocupação é com a segmentação do Relator da Receita e Relator da Despesa. O relatório da despesa passa a ser fracionado, porque são dados poderes maiores aos relatores setoriais, às comissões permanentes etc. Minha preocupação é com o fato de se fragmentar demais o orçamento e perdermos a visão de conjunto. Temos um relatório apenas trabalhado a partir dos aspectos corporativos e podemos fortalecer muito os lobbies e perspectivas corporativas, perdendo de vista o conjunto da obra, os grandes desafios da peça orçamentária. O orçamento tem que dar conta de um projeto de nação, e o relator-geral é quem deve ter, de alguma maneira, poderes para fazer ajustes, evidentemente sempre devendo ser submetidas suas sugestões aos plenários da CMO e do Congresso. Mas minha preocupação é com a excessiva fragmentação. Acho justo que haja maior participação dos deputados, que haja até um relator preocupado com a receita, mas desde que não se retire também do RG essa prerrogativa de ele ser aquele que detém a preocupação com relação ao projeto global do orçamento. Minha preocupação é fragilizar demais o papel do Relator-Geral"

23) Ator: Sibá Machado (PT, coalizão)

Instância: Comissão 2005

Data: 7/4/2005, p. 195

Idéia: Contra Relator da Receita

Interesse curto prazo: Pertencimento à coalizão

Frame Eficiência Processual: "Fico preocupado com a existência do Relator da Receita porque alguém precisa assinar a responsabilidade do texto final. Alguém precisa ser o responsável. Assim, fiquei em dúvida se o fato de estarmos constituindo dois relatores, quase de cunho geral, estaria criando uma ambigüidade nessa relação. Outro aspecto que me preocupa é qual o momento em que o fluxo dessas informações poderá cruzar com o tempo hábil. Se temos um único relator, o comando está em suas mãos; se vamos ter dois relatores, implicará, em um momento posterior, o acontecimento desse cruzamento".

24) Ator: Ricardo Barros (PP, oposição)

Instância: Comissão 2005

Data: 7/4/2005, p. 199

Idéia: A favor do Relator da Receita

Interesse curto prazo: Pertencimento à oposição

Frame Difusão: "Sugiro a criação do Relator da Receita por causa de uma discussão que existe sobre separação da receita e despesa em outros parlamentos. O fato de o relator ser da minoria também é uma prerrogativa que existe em outros parlamentos".

25) Ator: Fernando Coruja (PPS, oposição)

Instância: Comissão 2005

Data: 5/4/2005, p. 143-144

Idéia: Contra Relator da Receita indicado pela oposição

Interesse curto prazo: Preferência Deslocada 
Frame Legitimidade do Executivo: "A indicação de um Relator da Receita pelo líder da minoria é complicado. Estamos tratando de uma questão de elaboração do orçamento, que é fundamentalmente de governo. O líder da minoria é um líder da oposição na Casa. Embora tenhamos participação ampla, temos que tomar cuidado para não criar um conflito. Imaginem se o líder da minoria acha que a receita é tanto e o da maioria acha que é outro tanto, vai-se criar um conflito, independentemente de quem esteja no governo"

26) Ator: Wasny de Roure (PT, coalizão)

Instância: Comissão 2005

Data: 7/4/2005, p. 196

Idéia: A favor do Relator da Receita

Interesse curto prazo: Preferência Deslocada

Frame Legimitidade/Eficiência parlamentar: "É verdade que temos assistido, em alguns casos, a um inchamento da Receita, mas acredito que esteja demonstrado que o Congresso tem acertado mais do que o próprio governo, quando chega aqui e faz algumas adaptações na própria capacidade de arrecadação do Estado".

27) Ator: Iberê Ferreira (PTB, coalizão)

Instância: Comissão 2005

Data: 7/4/2005, p. 198

Idéia: A favor do Relator da Receita

Interesse curto prazo: Preferência Deslocada

Frame Eficiência Processual: "Quero louvar a sugestão de separar a Receita da Despesa. Temos visto a pressão que o relator-geral recebe no sentido de alterar a demanda de seus colegas, deputados e senadores"

28) Ator: Ricardo Barros (PP, oposição)

Instância: Comissão 2005

Data: 5/4/2005, p. 142

Idéia: Relator da Receita seria indicado pela oposição

Interesse curto prazo: Pertencimento à oposição

Frame: Participação Parlamentar: "O relator da despesa é indicado pelo maior partido ou pelo acordo com o governo. O relator da receita é indicado pela minoria. É uma sugestão para debater, mas que penso ser lógica: a minoria autoriza e o governo gasta. Estou propondo uma democratização, porque a maioria pode escolher o relator da despesa entre os da maioria, não precisa ser necessariamente a maior bancada"

29) Ator: Ricardo Barros (PP, oposição)

Instância: Comissão 2005

Data: $31 / 3 / 2005$, p. 96

Idéia: A favor do Relator da Receita

Interesse curto prazo: Pertencimento à oposição

Frame Barganha Política: "Temos que discutir a separação do relator da receita do relator da despesa, ou seja, adotar um relator de receita com prazo definido. Vamos dizer, em 15/novembro, ou 30/outubro, a receita tem de estar aprovada e não se muda mais. Será com ela que iremos trabalhar, e não como ocorre hoje em que os relatórios da receita e da despesa são os mesmos, e conforme a pressão sobre a despesa, encontra-se mais razoes para justificar o aumento da receita. Com essa separação, teríamos mais segurança. Haveria como justificar aquela receita. Além disso, o relator da despesa terá de trabalhar com aquele limite aprovado anteriormente, isto é, no início de seu trabalho na comissão".

30) Ator: Ricardo Barros (PP, oposição)

Instância: Comissão 2005

Data: 20/4/2005, p. 31-32

Idéia: Criação do Relator de Receita

Interesse curto prazo: Pertencimento à oposição

Frame Justiça Procedimental: "Proponho a criação da figura do Relator de Receita, com o objetivo de que aquele que reestimar a receita não seja o mesmo que vai aplicar a receita reestimada. Com isso, esperamos ter mais isenção na reestimativa da receita. Pois o relatório da receita será aprovado antes do parecer preliminar, sendo que o seu resultado final fará parte, portanto, do parecer preliminar, não podendo mais ser alterada a receita até o final da tramitacao do orçamento. De modo que não teremos mais aquela reincidência da alocação de novos recursos durante a tramitação, o que prejudica 
especialmente aqueles relatores setoriais que não participaram da discussão acerca da disposição desses novos recursos" 


\section{Bibliografia}

Abbink, Klaus. "Staff rotation as an anti-corruption policy", European Journal of Political Economy, v. 20, n. 4, 2004, p. 887-906.

Abrucio, Fernando. Os Barões da Federação. São Paulo, Usp/Hucitec, 1998.

Acosta,Andrés Mejía; Albornoz, Vicente \& Araujo, M. Caridad. "Institutional reforms, budget politics, and fiscal outcomes in Ecuador", in Hallerberg, Mark; Scartascini, Carlos \& Stein, Ernesto (eds.) Who decides the budget? A political economy analysis of the budget process in Latin America. Cambridge, Harvard University Press, 2009, p. 123-156.

Adler, E. Scott. 2002. Why Congressional Reforms Fail: Reelection and the House Committee System. Chicago, University of Chicago Press, 2002.

Afonso, José Roberto Rodrigues. "Memórias da Assembléia Nacional Constituinte de 1987/88: as finanças públicas". Texto disponível em http://www.bndes.gov.br/conhecimento/revista/rev1102.pdf, acessado em janeiro de 2008.

Alesina, Alberto \& Perotti, Roberto. "Fiscal discipline and the budget process", American Economic Review, v. 86, n. 2, 1996, p. 401-407.

Alston, Lee J. \& Mueller, Bernardo. "Pork for Policy: executive and legislative exchange in Brazil", Journal of Law, Economics and Organization, v. 22, n. 1, 2005, p. 87-114.

Ames, Barry. "O congresso e a política orçamentária no Brasil durante o período pluripartidário", Dados, v. 29, n. 2, 1986, p. 177-205.

"Party discipline in the Chamber of Deputies", in Morgenstern, Scott \& Nacif,

Benito (eds.) Legislative Politics in Latin America. Cambridge, Cambridge University Press, 2002, p. 185-221.

Amorim Neto, Octavio; Cox, Gary W. \& McCubbins, Mathew. "Agenda Power in Brazil's Câmara dos Deputados, 1989-98”, World Politics, v. 55, 2003, p. 550-578.

Appel, Hilary. "The ideological determinants of liberal economic reform: the case of privatization", World Politics, v. 52, n. 4, 2000, p. 520-549.

Armijo, Leslie Elliott; Faucher, Philippe \& Dembinska, Magdalena. "Compared to what? Assessing Brazil's political institutions”, Comparative Political Studies, v. 39, n. 6, 2006, p. 759-786.

Armstrong, J.-S. "Relative accuracy of judgmental and extrapolative methods in forecasting annual earning", Journal of Forecasting, v. 2, 1983, p. 437-447.

Arretche, Marta. 2007, "The Veto Power of Sub-National Governments in Brazil: Political Institutions and Parliamentary Behavior in the Post-1988 Period." Brazilian Political Science Review, v. 1, n. 2, 2007, p. 40-73. 
Baaklini, Abdo. O Congresso e o sistema político brasileiro. Rio de Janeiro, Paz e Terra, 1993.

Bachrach, Peter \& Baratz, Morton. "Two faces of power", American Political Science Review, v. 56, n. 4, 1962, p. 947-952.

. "Decisions and nondecisions: an analytical framework", American Political Science Review, v. 57, n. 3, 1963, p. 632-642.

Barbosa, Lucídio Bicalho. As prioridades fixadas na Lei de Diretrizes Orçamentárias para a Administração Pública Federal importam? Dissertação de mestrado em Ciência Política, Universidade de Brasília, 2006.

Baron, David \& Ferejohn, John. "Bargaining in legislatures", American Political Science Review, v. 83, 1989, p. 1181-1206.

Barrett, Andrew W. "Are all presidential legislative successes really victories? Examining the substance of legislation", White House Studies, v. 5, n. 2, 2005, p. 133151.

\& Eshbaugh-Soha, Matthew. "Presidential success on the substance of legislation", Political Research Quarterly, v. 60, n. 1, 2007, p. 100-112.

Barros, Ricardo. De olho no dinheiro do Brasil. Brasília, Editora 24x7 Cultural, 2007.

Baumgartner, Frank. \& Jones, Bryan. Agendas and instability in american politics. Chicago, University of Chicago Press, 1993. (eds.) Policy dynamics. Chicago, University of Chicago Press, 2002.

Bawn, Kathleen. "Constructing 'us': ideology, coalition politics, and false consciousness", American Journal of Political Science, v. 43, n. 2, 1999, p. 303-334. . "The logic of institutional preferences: german electoral law as a social choice outcome", American Journal of Political Science, v. 37, n. 4, 1993, p. 965-989.

Béland, Daniel. "Ideas and social policy: an institutionalist perspective", Social Policy \& Administration, v. 39, n. 1, 2005, p. 1-18.

Bennett, Andrew \& Elman, Colin. "Complex causal relations and case study methods: the example of path dependence", Political Analysis, v. 14, n. 3, 2006, p. 250-267.

Bezerra, Marcos Otávio. Em nome das "bases": política, favor e dependência pessoal. Rio de Janeiro, Ed. Relume Dumará, 1999.

Bittencourt, Fernando Moutinho Ramalho. Alocação de recursos e processo decisório no Congresso Nacional: os projetos de investimento em transportes rodoviários no Orçamento federal, 2002-2007. Senado Federal, Unilegis, 2008.

Block, Cheryl D. "Budget gimmicks", in Garrett, Elizabeth; Graddy, Elizabeth A. \& Jackson, Howell E. (eds.) Fiscal challenges: an interdisciplinary approach to budget policy. Cambridge, Cambridge University Press, 2008, p. 39-67. 
Blustein, Paul. The chastening: inside the crisis that rocked the global financial system and humbled the IMF. New York, PublicAffairs, 2001.

Blyth, Mark. "Structures do not come with an instruction sheet: interests, ideas, and progress in political science", Perspectives on Politics, v. 1, n. 4, 2003, p. 695-706.

Bourdieu, Pierre. Sobre a televisão. Rio de Janeiro, Ed. Zahar, 1997.

Bukovansky, Mlada. "The hollowness of anti-corruption discourse", Review of International Political Economy, v. 13, n. 2, 2006, p. 181-209.

Caetano, Bruno. "Executivo e Legislativo na esfera local", Novos Estudos Cebrap, n. 71, 2005, p. 101-125.

Campbell, John L. "Ideas, politics, and public policy", Annual Review of Sociology, v. 28, 2002, p. 21-38. Press, 2004.

Institutional Change and Globalization. Princeton, Princeton University

Campos, Roberto. "O Poder Legislativo e o Desenvolvimento", in Mendes, Candido

(org.) O Legislativo e a Tecnocracia. Rio de Janeiro, Imago Editora/Conjunto Universitário Candido Mendes, 1975.

. A Lanterna na Popa. Rio de Janeiro, Topbooks, 1994.

Campello de Souza, Maria do Carmo. Estado e Partidos Políticos no Brasil (1930 a 1964). São Paulo, Alfa-Ômega, 1976.

Capella, Ana Cláudia N. "Perspectivas teóricas sobre o processo de formulação de políticas públicas", Revista Brasileira de Informação Bibliográfica em Ciências Sociais, n. 61, 2006, p. 25-52.

Capoccia, Giovanni \& Kelemen, Daniel R. "The study of critical junctures: theory, narrative, and counterfactuals in historical institutionalism", World Politics, v. 59, 2007, p. 341-369.

Cardoso, Fernando Henrique. A arte da política: a história que vivi. Rio de Janeiro, Ed. Civilização Brasileira, 2006.

Carneiro, Mônica de Castro Mariano. Um toque de Midas: transformações observadas na Comissão de Orçamento no período de 1988 a 2003. Dissertação de Mestrado, Departamento de Sociologia da UnB, 2005.

Carranza, Luis; Chávez, Jorge F. \& Valderrama, José. "Success in sustainability? The case of Peru", in Hallerberg, Mark; Scartascini, Carlos \& Stein, Ernesto (eds.) Who decides the budget? A political economy analysis of the budget process in Latin America. Cambridge, Harvard University Press, 2009, p. 191-224.

Carreirão, Yan. "A eleição presidencial de 2002: uma análise preliminar do processo e dos resultados eleitorais", Revista de Sociologia e Política, v. 22, 2004, p. 179-194. 
Carvalho, Nelson Rojas de. E no início eram as bases: geografia política do voto e comportamento legislativo no Brasil. Rio de Janeiro, Ed. Revan, 2003.

Cheibub, José Antonio. "Presidentialism, electoral identifiability, and budget balances in democratic systems", American Political Science Review, v. 100, n. 3, 2006, p. 353368 .

Figueiredo, Argelina \& Limongi, Fernando. "Political parties and governors as determinants of legislative behavior in Brazil's Chamber of Deputies, 1988-2006", Latin American Politics and Society, v. 51, n. 1, 2009, p. 1-30.

Coelho, Ricardo Corrêa. Partidos políticos, maiorias parlamentares e tomada de decisão na Constituinte. Tese de Doutorado em Ciência Política, Universidade de São Paulo, 1999.

Collier, David \& Mahoney, James. "Insights and Pitfalls: Selection Bias in Qualitative Research", World Politics, v. 49, n. 1, 1996, p. 56-91.

Collier, Ruth \& Collier, David. Shaping the political arena: critical junctures, the labor movement and regime dynamics in Latin America. Princeton, Princeton University Press, 1991.

Collins, Randall. Four Sociological Traditions. New York, Oxford University Press. 1994.

Congresso Nacional. Secretaria Legislativa do Senado Federal. Subsecretaria de Comissões. Relatório final da Comissão Parlamentar Mista de Inquérito criada através do Requerimento 151/1993 do Congresso Nacional destinada a "apurar fatos contidos nas denúncias do Sr. José Carlos Alves dos Santos, referentes às atividades de parlamentares, membros do governo e representantes de empresas envolvidas na destinação de recursos do Orçamento da União". Brasília, Janeiro de 1994, 5 volumes.

Couto, Cláudio Gonçalves e Arantes, Rogério Bastos. "Constituição, governo e democracia no Brasil." Revista Brasileira de Ciências Sociais, v. 21, n. 61, p. 41-62, 2006.

Couture, Jérôme \& Imbeau, Louis M. "Do governments manipulate their revenue forecasts? Budget speech and budget outcomes in the canadian provinces", in Imbeau, Louis. (ed.) Do they walk like they talk? Speech and action in policy processes. New York, Springer, 2009, p. 155-166.

Cox, Gary. "On the effects of legislative rules", Legislative Studies Quarterly, v. 25, n. 2, 2000, p. 169-192.

Crenson, Matthew A. The un-politics of air pollution: a study of nondecisionmaking in the cities. Baltimore, Johns Hopkins Press, 1971.

Dahl, Robert. Who governs? Democracy and power in an American city. New Haven, Yale University Press, 1961. 
Dantas, Humberto. "Direitos políticos e participação popular: entre o desejo e a cultura política nacional", in Praça, Sérgio \& Diniz, Simone (orgs.) Vinte Anos de Constituição. São Paulo, Ed. Paulus, 2008, p. 227-246.

Dantas Neto, Paulo Fábio. Tradição, autocracia e carisma: a política de Antônio Carlos Magalhães na modernização da Bahia (1954-1974). Rio de Janeiro, Iuperj, 2006.

Departamento Intersindical de Assessoria Parlamentar. Quem foi quem na Constituinte nas questões de interesse dos trabalhadores. São Paulo, Ed. Cortez, 1988.

Diniz, Simone. "Interações entre os poderes executivo e legislativo no processo decisório: avaliando sucesso e fracasso presidencial", Dados, v. 48, n. 2, 2005, p. 333369.

\& Noronha, Lincoln. "Direitos Trabalhistas e Sindicais: O Conservadorismo da Constituição de 1988 e das Tentativas de Reforma nos Anos 90", in Praça, Sérgio \& Diniz, Simone (orgs.) Vinte Anos de Constituição. São Paulo, Ed. Paulus, 2008, p. 139-159.

Downs, Anthony. An economic theory of democracy. New York, Harper \& Row, 1957.

Drake, Paul. The money doctor in the Andes: The Kemmerer missions, 1923-1933. Durham, Duke University Press, 1989.

Elster, Jon. "Equal or Proportional? Arguing and Bargaining over the Senate at the Federal Convention", in Knight, Jack \& Sened, Itai. (eds.) Explaining Social Institutions. Ann Arbor, University of Michigan Press, 1995, p. 145-160. . "Deliberation and Constitution Making", in Elster, Jon (ed.) Deliberative Democracy. Cambridge, Cambridge University Press, 1998.

Explaining social behavior: more nuts and bolts for the social sciences.

Cambridge, Cambridge University Press, 2007.

Enderlein, Henrik \& Lindner, Johannes. "The EU budgetary procedure in the Constitutional debate", in Richardson, Jeremy. (ed.) European Union: power and policy-making. $3^{\text {rd }}$ edition. New York, Routledge, 2006, p. 187-205.

Entman, Robert M. "Framing: Toward Clarification of a Fractured Paradigm", Journal of Communication, v. 43, n. 4, 1993, p. 51-58.

Fabrizio, Stefania \& Mody, Ashoka. "Breaking the Impediments to Budgetary Reforms: Evidence from Europe”. IMF Working Paper 08/82, March 2008.

Falleti, Tulia G. \& Lynch, Julia F. "Context and causal mechanisms in political analysis", Comparative Political Studies, 2009, forthcoming.

Figueiredo, Argelina. "Government coalitions in brazilian democracy", Brazilian Political Science Review, v. 1, n. 2, 2007, p. 182-216. 
Figueiredo, Argelina \& Limongi, Fernando. Executivo e Legislativo na nova ordem constitucional. Rio de Janeiro, Ed. FGV, 1999.

"Presidential power, legislative organization, and party behavior in Brazil", Comparative Politics, v. 32, n. 2, 2000, p. 151-170.

" "Processo Orçamentário e Comportamento Legislativo: Emendas Individuais, Apoio ao Executivo e Programas de Governo", Dados, v. 48, n. 4, 2005, p. 737-776.

Política orçamentária no presidencialismo de coalizão. Rio de Janeiro, Ed. FGV, 2008.

Finocchiaro, Charles J. \& Jenkins, Jeffery. "In search of killer amendments in the modern U.S. House”, Legislative Studies Quarterly, v. 33, n. 2, 2008, p. 263-294.

Fiuza, Guilherme. 3.000 dias no bunker. Rio de Janeiro, Ed. Record, 2006.

Fleischer, David \& Marques, Jales. De Facção a Partido: A Fundação e Evolução do PSDB, 1987-1998. Brasília, Instituto Teotônio Vilela, 1999.

Freitas, Andréa Marcondes de. Migração partidária na Câmara dos Deputados. Dissertação de Mestrado, Departamento de Ciência Política, Universidade de São Paulo, 2008.

Gaddis, John Lews. The landscape of history: how historians map the past. Oxford, Oxford University Press, 2002.

Gandhi, Jennifer. Political institutions under dictatorship. Cambridge, Cambridge University Press, 2008.

Gauthier, Bernard \& Wane, Waly. "Leakage of Public Resources in the Health Sector: An Empirical Investigation of Chad”, World Bank Working Paper, 2006.

Geddes, Barbara. Paradigms and sand castles: theory building and research design in comparative politics. Ann Arbor, University of Michigan Press, 2003.

Genschel, Philipp. "The dynamics of inertia: institutional persistence and change in telecommunications and health care", Governance, v. 10, n. 1, 1997, p. 43-66.

George, Alexander L. \& Bennett, Andrew. Case Studies and Theory Development in the Social Sciences. Boston, MIT Press, 2005.

Gomes, Sandra. "O impacto das regras de organização do processo legislativo no comportamento dos parlamentares: um estudo de caso da Assembléia Nacional Constituinte (1987-1988)", Dados, v. 49, n. 1, 2006, p. 193-224.

Gonçalves da Silva, Marcos Fernandes. A economia política da corrupção no Brasil. São Paulo, Ed. Senac, 2002.

Goodin, Robert. "Instititutions and their design", in Goodin, Robert. (ed.) The Theory of Institutional Design. Cambridge, Cambridge University Press, 1996, p. 1-53. 
Greif, Avner \& Laitin, David. “A theory of endogenous institutional change”, American Political Science Review, v. 98, n. 4, 2004, p. 633-652.

Hacker, Jacob. "Privatizing risk without privatizing the welfare state: the hidden politics of social policy retrenchment in the United States", American Political Science Review, v. 98, n. 2,2004 , p. 243-260.

Hall, Peter. "The role of interests, institutions, and ideas in the comparative political economy of the industrialized nations", in Lichbach, Mark I. \& Zuckerman, Alan S. (eds.) Comparative Politics: Rationality, Culture, and Structure. Cambridge, Cambridge University Press, 1997, p. 174-207.

"Preference Formation as a Political Process: The Case of Monetary Union in Europe", in Katznelson, Ira \& Weingast, Barry. (eds.) Preferences and Situations: Points of Intersection between Historical and Rational Choice Institutionalism. New York, Russell Sage Foundation, 2005, p. 129-160.

Hallerberg, Mark; Rainer Strauch, Rolf \& von Hagen, Jürgen. Fiscal governance in Europe. Cambridge, Cambridge University Press, 2009.

Hay, Colin. Political analysis: a critical introduction. New York, Palgrave Macmillan, 2002.

Hedström, Peter and Swedberg, Richard. "Social mechanisms: an introductory essay", in Hedström, Peter and Swedberg, Richard (eds.) Social Mechanisms: An Analytical Approach to Social Theory. Cambridge, Cambridge University Press, 1998, p. 1-31.

Heller, William. "Bicameralism and Budget Deficits: the effect of parliamentary structure on government spending", Legislative Studies Quarterly, v. 22, n. 4, 1997, p. 485-516.

\& Mershon, Carol. "Integrating theoretical and empirical models of party switching", in Heller, William B. \& Mershon, Carol. (eds.) Political parties and legislative party switching. New York, Palgrave Macmillan, 2009, p. 29-51.

Helmke, Gretchen \& Levitsky, Steven. "Introduction" in Helmke, Gretchen \& Levitsky, Steven (eds.) Informal Institutions and Democracy: lessons from Latin America. Baltimore, Johns Hopkins University Press, 2006, p. 1-30.

Henson, Jayne R. \& Benoit, William Lyon. "Functional federalism in political campaign debates", Publius, v. 39, n. 4, 2009, p. 696-706.

Isaacson, Walter. Einstein: his life and universe. New York, Simon \& Schuster, 2007.

Isaksen, Jan. "The budget process and corruption". Bergen: Chr. Michelsen Institute. U4 Issue 3, 2005.

Kalnins, Valts. "Assessing trends in corruption and impact of anti-corruption measures". OECD Working Paper, 2005.

Katznelson, Ira. "Periodization and Preferences: reflections on purposive action in comparative historical social science”, in Mahoney, James \& Rueschemeyer, Dietrich. 
(eds.) Comparative Historical Analysis in the Social Sciences. Cambridge, Cambridge University Press, 2003, p. 270-301.

. \& Barry R. Weingast. "Intersections between Historical and Rational Choice Institutionalism", in Katznelson, Ira \& Weingast, Barry. (eds.) Preferences and Situations: Points of Intersection between Historical and Rational Choice Institutionalism. New York, Russell Sage Foundation, 2005, p. 1-24.

King, Anthony. "Ideas, institutions and the policies of governments: a comparative Analysis: parts I and II", British Journal of Political Science, v. 3, n. 3, 1973a, p. 291313.

"Ideas, institutions and the policies of governments: a comparative analysis: part III”, British Journal of Political Science, v. 3, n. 4, 1973b, p. 409-423.

King, Gary; Keohane, Robert O. \& Verba, Sidney. Designing social inquiry: scientific inference in qualitative research. Princeton, Princeton University Press, 1994.

Kingdon, John W. Agendas, alternatives, and public policies. New York, AddisonWesley, 1995.

Kingston, Christopher \& Caballero, Gonzalo. "Comparing theories of institutional change", Journal of Institutional Economics, v. 5, n. 2, 2009, p. 151-180.

Kinzo, Maria D’Alva. "O Quadro Partidário na Constituinte”, in Lamounier, Bolívar (org.) De Geisel a Collor: O Balanço da Transição. São Paulo, IDESP, 1990.

Knight, Jack. Institutions and Social Conflict. Cambridge, Cambridge University Press, 1992.

\& Sened, Itai (eds.). Explaining Social Institutions. Ann Arbor, University of Michigan Press, 1995.

Krasner, Stephen D. "Approaches to the state: alternative conceptions and historical dynamics”, Comparative Politics, v. 16, n. 2, 1984, p. 223-246.

Krieger, Gustavo; Rodrigues, Fernando \& Bonassa, Elvis. Os donos do Congresso. São Paulo, Ática, 1994.

Krugman, Paul. "The narrow and broad arguments for free trade", American Economic Review, v. 83, n. 2, 1993, p. 362-366.

Kupfer, David. “Desenvolvimento mínimo”, Valor Econômico, 8/2/2006.

Lamounier, Bolívar. Partidos e Utopias: o Brasil no limiar dos anos 90. São Paulo, Ed. Loyola, 1989.

"A Comissão Afonso Arinos e os debates constituintes", in Praça, Sérgio \& Diniz, Simone (orgs.) Vinte Anos de Constituição. São Paulo, Ed. Paulus, 2008, p. 1928.

Lauth, Hans-Joachim. "Informal Institutions and Democracy", Democratization, v. 7, n. 4, 2000, p. 21-50. 
Lemos, Leany. "El sistema de comisiones en el Senado Brasileño: jerarquia y concentración de poderes en la década de 1990", América Latina Hoy, v. 43, 2006, p. 155-182.

\& Ranincheski, Sonia. "Carreiras políticas no Senado brasileiro: um estudo das composições do plenário e da Comissão de Constituição, Justiça e Cidadania na década de 90", in Lemos, Leany. (org.) O Senado Federal brasileiro no pósconstituinte. Brasília, Senado Federal/Unilegis, 2008, p. 87-120.

Levi, Margaret. "A logic of institutional change", in Cook, Karen Schweers \& Levi, Margaret (eds.) The limits of rationality. Chicago, University of Chicago Press, 1990, p. 402-18.

."A State of Trust", in Valerie Braithwaite and Levi, Margaret (eds.) Trust and Governance. New York, Russell Sage Foundation, 1999, p. 77-101.

"Reconsiderations of rational choice in comparative and historical analysis", in Lichbach, Mark I. \& Zuckerman, Alan (eds.) Comparative Politics: rationality, culture, and structure, $2^{\text {nd }}$ edition. Cambridge, Cambridge University Press, 2009, p. 117-133.

Lieberman, Robert C. "Ideas, Institutions, and Political Order: Explaining Political Change”, American Political Science Review, v. 96, n. 4, 2002, p. 697-712.

Lima, Edilberto Carlos Pontes \& Miranda, Rogério Boueri. "O processo orçamentário federal brasileiro", in Mendes, Marcos (org.) Gasto público eficiente: 91 propostas para o desenvolvimento do Brasil. Rio de Janeiro, Topbooks, 2006, p. 319-373.

Limongi, Fernando. "O novo institucionalismo e os estudos legislativos: a literatura norte-americana recente", Revista de Informação Bibliográfica em Ciências Sociais, n. 37, 1994, p. 3-38.

"O Poder Executivo na Constituição de 1988", in Oliven, George Ruben; Ridenti, Marcelo \& Brandão, Gildo Marçal (orgs.) A Constituição de 1988 na Vida Brasileira. São Paulo, Editora Hucitec, 2008, p. 23-56.

Limongi, Fernando \& Figueiredo, Argelina. "Medidas Provisórias", in Benevides, Maria Victória; Vannuchi, Paulo \& Kerche, Fábio. (orgs.) Reforma política e cidadania. São Paulo, Perseu Abramo, 2003.

"Partidos políticos na Câmara dos Deputados (1989-1994)", Dados, v. 38, n. 3, 1995, p. 497-525.

Lindner, Johannes. "Institutional stability and change: two sides of the same coin", Journal of European Public Policy, v. 10, n. 6, 2003, p. 912-935.

Loureiro, Maria Rita \& Abrucio, Fernando. "Política e reformas fiscais no Brasil recente", Revista de Economia Política, v. 24, n. 1, 2004, p. 50-72.

Lowi, Theodore J. "American Business, Public Policy, Case Studies, and Political Theory”, World Politics, v. 16, 1964, p. 677-715.

Macedo, João \& Nerosky, Luiz. “O processo orçamentário brasileiro”. Banco Mundial, 2000, mimeo. 
Madureira, Jane Marchi \& Jard, Sidney. "A mulher na legislação previdenciária antes e depois da Constituição de 1988”, in Praça, Sérgio \& Diniz, Simone (orgs.) Vinte Anos de Constituição. São Paulo, Ed. Paulus, 2008, p. 161-178.

Mahoney, James. "Path dependence in historical sociology", Theory and Society, v. 29, n. 4, 2000, p. 507-548.

"Combining Institutionalisms: Liberal Choices and Political Trajectories in

Central America", in Katznelson, Ira \& Weingast, Barry. (eds.) Preferences and Situations: Points of Intersection between Historical and Rational Choice Institutionalism. New York, Russell Sage Foundation, 2005, p. 313-333.

\& Thelen, Kathleen. "A theory of gradual institutional change", in Mahoney, James \& Thelen, Kathleen. (eds.) Explaining Institutional Change: Ambiguity, Agency, and Power. Cambridge, Cambridge University Press, 2009, forthcoming.

Mainwaring, Scott \& Perez-Linan, Anibal. "Party Discipline in the Brazilian Constitutional Congress", Legislative Studies Quarterly, v. 22, n. 4, 1997, p. 453-483.

Majone, Giandomenico. Evidence, argument and persuasion in the policy process. New Haven, Yale University Press, 1989.

Maltzman, Forrest \& Shipan, Charles R. "Change, continuity, and the evolution of the law", American Journal of Political Science, v. 52, n. 2, 2008, p. 252-267.

Mancuso, Wagner Pralon. O lobby da indústria no Congresso Nacional: empresariado e política no Brasil contemporâneo. São Paulo, Edusp/Humanitas, 2007.

Marques, Rosa Maria \& Mendes, Áquilas. "A Previdência Social como política de garantia de renda", Valor Econômico, 14/9/2005.

Martinez-Lara, Javier. Building Democracy in Brazil. The Politics of Constitutional Change, 1985-95. New York, St. Martin's Press, 1996.

Mayhew, David. Congress: the electoral connection. New Haven, Yale University Press, 1974.

Meseguer, Covadonga. "Rational learning and bounded learning in the diffusion of policy innovations", Rationality and Society, v. 18, n. 1, 2006, p. 35-66.

Mesquita, Lara. Emendas ao orçamento e conexão eleitoral na Câmara dos Deputados brasileira. Dissertação de Mestrado, Departamento de Ciência Política da Universidade de São Paulo, 2009.

Miguel, Luís Felipe. "Mídia e eleições: a campanha de 1998 na Rede Globo", Dados, v. 42, n. 2, 1999, p. 253-276.

Miller, Gary. "Rational choice and dysfunctional institutions", Governance, v. 13, n. 4, 2000, p. 535-547. 
Mintrom, Michael. "Policy entrepreneurs and the diffusion of innovation", American Journal of Political Science, v. 41, n. 3, 1997, p. 738-770.

Moe, Terry. "Power and Political Institutions", Perspectives on Politics, v. 3, n. 2, 2005, p. 215-33.

Molinas, José R.; Pérez-Liñán, Aníbal; Hallerberg, Mark \& Morgan, Audrey. "Weakened policymaking process, deteriorating fiscal outcomes: the case of Paraguay", in in Hallerberg, Mark; Scartascini, Carlos \& Stein, Ernesto (eds.) Who decides the budget? A political economy analysis of the budget process in Latin America. Cambridge, Harvard University Press, 2009, p. 157-190.

Müller, Gustavo. "Comissões e partidos políticos na Câmara dos Deputados: um estudo sobre os padrões partidários de recrutamento para as comissões permanentes", Dados, v. 48, n. 1, 2005, p. 371-394.

Naurin, Daniel. Deliberation behind closed doors: transparency and lobbying in the European Union. Essex, ECPR Press, 2007.

Nóbrega, Mailson da. O futuro chegou: instituições e desenvolvimento no Brasil. São Paulo, Ed. Globo, 2005.

Oliveira, Vanessa. "A Descentralização Inconclusa: a Constituição de 1988 e as fases da descentralização da saúde no Brasil", in Praça, Sérgio \& Diniz, Simone (orgs.) Vinte anos de Constituição. São Paulo, Ed. Paulus, 2008, p. 179-200.

Olsen, Johan P. "Change and continuity: an institutional approach to institutions of democratic government”, European Political Science Review, v. 1, n. 1, 2009, p. 3-32.

Pan, Zhongdnang \& Kosicki, Gerald M. "Framing Analysis: An Approach to New Discourse", Political Communication, v. 10, 1993, p. 55-75.

Pedriana, Nicholas. "Rational choice, structural context, and increasing returns: a strategy for analytic narrative in historical sociology", Sociological Methods \& Research, v. 33, n. 3, 2005, p. 349-382.

Pereira, Carlos \& Rennó, Lúcio. "Successful reelection strategies in Brazil: the electoral impact of distinct institutional incentives", Electoral Studies, v. 22, 2003, p. 425-448.

\& Mueller, Bernardo. "The cost of governing: strategic behaviour of the president and legislators in Brazil's budgetary process", Comparative Political Studies, v. 37, n. 7, 2004, p. 781-815.

Power, Timothy \& Rennó, Lucio. "Agenda power, executive decree authority, and the mixed results of reform in the Brazilian Congress", Legislative Studies Quarterly, v. 33, n. 1, 2008, p. 5-33.

; Power, Timothy J. \& Raile. Eric D. "Presidentialism, Coalitions, and Accountability," in Power, Timothy J. \& Taylor, Matthew M. (eds). Corruption and Democracy in Brazil The Struggle for Accountability. South Bend, University of Notre Dame Press, forthcoming. 
. \& Orellana, Salomon. "Hybrid political institutions and governability: the budgetary process in Brazil", Journal of Politics in Latin America, v. 1, n. 3, 2009, p. 57-79.

Perezino, Luiz Fernando de Mello. A preponderância do Poder Executivo no processo orçamentário. Brasília, Senado Federal/Unilegis, 2008.

Pierson, Paul. "Increasing returns, path dependence, and the study of politics", American Political Science Review, v. 94, n. 2, 2000, p. 251-267.

"The limits of design: explaining institutional origins and change", Governance, v. 13, n. 4, 2000, p. 475-499.

Politics in Time: History, Institutions and Social Analysis. Princeton, Princeton University Press, 2004.

Pilatti, Adriano. A Constituinte de 1987-1988: Progressistas, Conservadores, Ordem Econômica e Regras do Jogo. Rio de Janeiro, Ed. Lumen Júris, 2008

Pinheiro, Vinícius Carvalho. "Inflação, poder e processo orçamentário no Brasil", Revista do Serviço Público, v. 120, n. 1, 1996, p. 141-164.

Piscitelli, Roberto B. "Orçamento Autorizativo x Orçamento Impositivo". Brasília, Câmara dos Deputados, Consultoria Legislativa, 2006.

Pontes Lima, Edilberto Carlos. "Algumas observações sobre o orçamento impositivo no Brasil”, Planejamento e Políticas Públicas, n. 26, 2003, p. 7-16.

Power, Timothy. "Optimism, pessimism, and coalitional presidentialism: debating the institutional design of brazilian democracy", Bulletin of Latin American Research, 2009 , forthcoming. \& Rae, Nicol C. Exporting Congress? The influence of U.S. Congress on world legislatures. Pittsburgh, University of Pittsburgh Press, 2006.

Praça, Sérgio. "Processo orçamentário: antecedentes, debates constituintes e mudanças após 1988", in Praça, Sérgio \& Diniz, Simone (orgs.) Vinte anos de Constituição. São Paulo, Ed. Paulus, 2008, p. 115-135.

. \& Diniz, Simone. "As duas faces da Constituição de 1988”, in Praça, Sérgio \& Diniz, Simone (orgs.) Vinte anos de Constituição. São Paulo, Ed. Paulus, 2008, p. 718.

Ribeiral, Tatiana. "Comissão de Constituição e Justiça: uma ilha de institucionalização no Congresso Nacional”, Revista do Legislativo, 1998.

Ricci, Paolo. "O conteúdo da produção legislativa brasileira: leis nacionais ou políticas paroquiais?", Dados, v. 46, n. 4, 2003, p. 699-734.

"A produção legislativa de iniciativa parlamentar no Congresso brasileiro: diferenças e similaridades entre a Câmara dos Deputados e o Senado Federal", in Lemos, Leany. (org.) O Senado Federal brasileiro no pós-constituinte. Brasília, Senado Federal/Unilegis, 2008, p. 237-271. 
. \& Lemos, Leany. "Produção legislativa e preferências eleitorais na Comissão de Agricultura e Política Rural da Câmara dos Deputados", Revista Brasileira de Ciências Sociais, v. 19, n. 55, 2004, p. 107-129.

Riker, William H. The art of political manipulation. New Haven, Yale University Press, 1986.

Samuels, David. "Progressive ambition, federalism, and pork-barreling in Brazil", in Morgenstern, Scott \& Nacif, Benito. (eds.) Legislative Politics in Latin America. Cambridge, Cambridge University Press, 2002, p. 315-340.

"Presidentialism and accountability for the economy in comparative

perspective", American Political Science Review, v. 98, n. 3, 2004, p. 1-12.

Sanches, Osvaldo M. "Alguns imperativos da reforma orçamentária", Boletim de Desenvolvimento Fiscal, IPEA, n. 5, Junho de 2007, p. 54-76

Santos, Fabiano. "Partidos e comissões no presidencialismo de coalizão", Dados, v. 45, n. 2, 2002, p. 237-264.

2007, p. $90-98$. "Afinal, quem manda no dinheiro?", Insight/Inteligência, Abril-Junho de . \& Almeida, Acir. "Teoria informacional e seleção de relatores na Câmara dos Deputados", Dados, v. 48, n. 4, 2005, p. 693-735.

Schattschneider, Elmer E. The Semi-Sovereign People. A Realist's Guide to Democracy in America. New York, Holt, 1960.

Schickler, Eric. Disjointed Pluralism: Institutional Innovation and the Development of the U.S. Congress. Princeton, Princeton University Press, 2001.

Schmidt, Vivien A. "Democracy and discourse in an integrating Europe and a globalising world", European Law Journal, v. 6, n. 3, 2000, p. 277-300.

"Does discourse matter in the politics of welfare state adjustment?", Comparative Political Studies, v. 35, n. 2, 2002, p. 168-193.

"Discursive institutionalism: the explanatory power of ideas and discourse", Annual Review of Political Science, v. 11, 2008, p. 303-326.

Schneider, Aaron. "Governance reform and institutional change in Brazil: federalism and tax", Commonwealth \& Comparative Politics, v. 45, n. 4, 2007, p. 475-498.

Schonhardt-Bailey, Cheryl. From the Corn Laws to Free Trade: Interests, Ideas, and Institutions in Historical Perspective. Massachussets, MIT Press, 2006.

Serra, José. O sonhador que faz: a vida, a trajetória política e as idéias de José Serra (entrevista a Teodomiro Braga). Rio de Janeiro, Ed. Record, 2002.

Sheingate, Adam. "Political Entrepreneurship, Institutional Change, and American Political Development", Studies in American Political Development, v. 17, 2003, p. 185-203. 
. "The terrain of the political entrepreneur", in Skowronek, Stephen \& Glassman, Matthew. (eds.) Formative acts: american politics in the making. Philadelphia, University of Pennsylvania Press, 2007, p. 13-31.

Shepsle, Kenneth. "A comment on institutional change", Journal of Theoretical Politics, v. 13, n. 3, 2001, p. 321-325.

"Losers in politics (and how they sometimes become winners): William

Riker's heresthetic", Perspectives on Politics, v. 1, n. 2, 2003, p. 307-315.

Shiller, Robert. "Why do people dislike inflation?". NBER Working Papers, n. 5539, 1996.

Sinclair, Barbara. Unorthodox lawmaking: new legislative processes in the U. S. Congress. Washington, Congressional Quarterly Press, 2007.

Soares, Rosinethe Monteiro. "Ciclo Orçamentário no Legislativo", 2007. Disponível em http://www.essere.com.br/artigos/orcamento_2007.pdf, acessado em fevereiro de 2008.

Souza, Celina. "Federalismo e descentralização na Constituição de 1988: processo decisório, conflitos e alianças", Dados, v. 44, n. 3, 2001, p. 513-560. - "Federalismo e conflitos distributivos: disputa dos estados por recursos orçamentários", Dados, v. 46, n. 2, 2003, p. 345-384. . "Regras e Contexto: As Reformas da Constituição de 1988”, Dados, v. 51, n. 4, 2008, p. 791-823.

Souza, Márcia Teixeira de Souza. "O processo decisório na Constituição de 1988: práticas institucionais”, Lua Nova, v. 58, 2003, p. 37-59.

Stewart, Charles. Budget Reform Politics: the design of the appropriations process in the House of Representatives, 1865-1921. Cambridge, Cambridge University Press, 1989.

Streeck, Wolfgang \& Thelen, Kathleen (eds.) Beyond Continuity: Institutional Change in Advanced Political Economies. Oxford, Oxford University Press, 2005

Taylor, Matthew M. Judging Policy: Courts and Policy Reform in Democratic Brazil. Stanford, Stanford University Press, 2008. "Institutional development through policy-making: a case study of the Brazilian Central Bank", World Politics, v. 61, n. 3, 2009, p. 487-515. . \& Vinicius Buranelli. "Ending up in Pizza: Accountability as a Problem of Institutional Arrangement in Brazil", Latin American Politics and Society, v. 49, n. 1, 2007, p. 59-87.

Thaler, Richard. "Anomalies: the winner's curse", Journal of Economic Perspectives, v. 2, n. 1, 1988, p. 191-202.

Thelen, Kathleen. "Historical institutionalism in comparative politics", Annual Review of Political Science, v. 2, 1999, p. 369-404. 
"How institutions evolve: insights from comparative-historical analysis", in Mahoney, James \& Rueschemeyer, Dietrich (eds.) Comparative historical analysis in the social sciences. New York, Cambridge University Press, 2003, p. 208-240.

"Institutions and social change: the evolution of vocational training in Germany", in Shapiro, Ian; Skowronek, Stephen \& Gavin, Daniel (eds.) Rethinking political institutions: the art of the state. New York, New York University Press, 2006.

.Institutional change in advanced political economies", British Journal of International Relations, v. 47, n. 3, 2009, p. 471-498.

Tollini, Helio. "Reforming the budget formulation process in the Brazilian Congress", OECD Journal on Budgeting, v. 1, 2009, p. 1-29.

Transparency International. Global Corruption Report 2007: corruption in judicial systems. Cambridge, Cambridge University Press, 2007.

Tsai, Kellee S. "Adaptive informal institutions and endogenous institutional change in China", World Politics, v. 59, n. 1, 2006, p. 116-141.

Tsebelis, George. Nested games: rational choice in comparative politics. Berkeley, University of California Press, 1990.

Tuchman, Gaye. Making news: a study in the construction of reality. New York, Free Press, 1978.

Velloso, Raul. "Ajuste fiscal através da redução de despesas obrigatórias”, in Mendes, Marcos (org.) Gasto público eficiente: 91 propostas para o desenvolvimento do Brasil. Rio de Janeiro, Topbooks, 2006, p. 111-136.

Veríssimo, Luís Fernando. Novas comédias da vida pública: a versão dos afogados. Porto Alegre, Ed. L\&PM, 1997.

Vianna Lopes. Júlio Aurélio. A Carta da Democracia: o processo constituinte da ordem pública de 2008. Rio de Janeiro, Topbooks, 2008.

Vieira, Vânia Cristina. As inovações no processo legislativo das leis orçamentárias à luz da Resolução 1/2006 do Congresso Nacional. Monografia apresentada no curso de Especialização em Orçamento Público da Unilegis. Brasília, DF, 2008.

Vieira, Simone Bastos (org.). A Constituição que não foi: história da Emenda Constitucional n. 1, de 1969. Brasília, Senado Federal, 2002.

Vis, Barbara \& Kersbergen, Kees van. "Why and how do political actors pursue risky reforms?", Journal of Theoretical Politics, v. 19, n. 2, 2007, p. 153-172.

Wagner, Michael W. "The utility of staying on message: competing partisan frames and public awareness of elite differences on political issues", The Forum, v. 5, n. 3, 2007, p. $1-18$. 
Walker, Jack. "Setting the Agenda in the U.S. Senate: A Theory of Problem Selection", British Journal of Political Science, v. 7, n. 4, 1977, p. 423-445.

Wehner, Joachim. "Assessing the power of the purse: an index of legislative budget institutions", Political Studies, v. 54, 2006, p. 767-785.

Weyland, Kurt. "Toward a new theory of institutional change", World Politics, v. 60, n. 2, 2008, p. 281-314.

.Bounded Rationality and Policy Diffusion: Social Sector Reform in Latin America. Princeton, Princeton University Press, 2007.

Whitehead, Laurence and Sola, Lourdes. "Introduction", in Sola, Lourdes and Whitehead, Laurence. Statecrafting monetary authority: democracy and financial order in Brazil. Oxford, Centre for Brazilian Studies, 2006, p. 1-12.

Wilson, James Q. Political Organizations. New York, Basic Books, 1973. 